\title{
Gebruik van slaap- en kalmeringsmiddelen in het dagelijks leven : determinanten, gevolgen en de rol van de huisarts
}

Citation for published version (APA):

Vissers, F. H. J. A. (1998). Gebruik van slaap-en kalmeringsmiddelen in het dagelijks leven : determinanten, gevolgen en de rol van de huisarts. [Doctoral Thesis, Maastricht University]. Universiteit Maastricht. https://doi.org/10.26481/dis.19981217fv

Document status and date:

Published: 01/01/1998

DOI:

10.26481/dis.19981217fv

Document Version:

Publisher's PDF, also known as Version of record

Please check the document version of this publication:

- A submitted manuscript is the version of the article upon submission and before peer-review. There can be important differences between the submitted version and the official published version of record.

People interested in the research are advised to contact the author for the final version of the publication, or visit the DOI to the publisher's website.

- The final author version and the galley proof are versions of the publication after peer review.

- The final published version features the final layout of the paper including the volume, issue and page numbers.

Link to publication

\footnotetext{
General rights rights.

- You may freely distribute the URL identifying the publication in the public portal. please follow below link for the End User Agreement:

www.umlib.nl/taverne-license

Take down policy

If you believe that this document breaches copyright please contact us at:

repository@maastrichtuniversity.nl

providing details and we will investigate your claim.
}

Copyright and moral rights for the publications made accessible in the public portal are retained by the authors and/or other copyright owners and it is a condition of accessing publications that users recognise and abide by the legal requirements associated with these

- Users may download and print one copy of any publication from the public portal for the purpose of private study or research.

- You may not further distribute the material or use it for any profit-making activity or commercial gain

If the publication is distributed under the terms of Article $25 \mathrm{fa}$ of the Dutch Copyright Act, indicated by the "Taverne" license above, 


\section{Gebruik}

van

slaap- en kalmeringsmiddelen in het dagelijks leven.

determinanten, gevolgen en de rol van de huisarts 
Het onderzoek gepubliceerd in dit proefschrift werd uitgevoerd binnen het Research Institute for Extramural and Transmural Health Care (ExTra), dat deel uitmaakt van the Netherlands School of Primary Care Research (CaRe), in 1995 erkend door de Koninkilike Nederlandse Akademie van Wetenschappen (KNAW).

ISBN 90-5681-047-2

cover design: Fien Huth 1990

lay-out: Frans Vissers

printing: Unigraphic, Universiteit Maastricht 


\section{Gebruik}

\section{van}

\section{slaap- en kalmeringsmiddelen in het dagelijks leven.}

determinanten, gevolgen en de rol van de huisarts

\section{Proefschrift}

ter verkrijging van de graad van doctor aan de Universiteit Maastricht, op gezag van de Rector Magnificus, Prof. dr. A.C. Nieuwenhuijzen Kruseman volgens het besluit van het College van Decanen,

in het openbaar te verdedigen op donderdag 17 december 1998 om 12.00 uur

door"

Frans H.J.A. Vissers 
Promotor:

Prof. dr. J.A. Knotnerus

\section{Copromotores:}

Di. R.F. van der Grinten

Dr. F.G.E.M. van der Horst

Beoordelingscommissie:

Prof, dr. F. Sturmans, voorzitter

Dr. J. Diederiks

Prof. dr. H.F. Kraan (Universiteit Twente)

Prof. dr. A.L.M. Lagro-Janssen (Katholieke Universiteit Nijmegen)

Prof. dr. P. Pop

Het onderzok werd gesubsidieerd door het Praeventiefonds, projektnr, 28-2186, alsmede door een bijdrage van de Commissie Veldintensief Onderzoek (CVO) van het Coördinatiebureau Eerste Lijn.

De uitgave van dit proefschrift kwam mede tot stand door bijdragen van:

Lorex Synthelabo b.v., Janssen-Cilag b.w., Wyeth-Lederle, Abbott b.v. en Yamanouchi b.v. 
aan mijn vader ${ }^{*}$, mijn moeder Sonja, Yvonne, Brigitte en Mirjam 
Paranymfen:

Drs. A.M. Muysken-du Saar

Drs. M.P.J.M. Peeters 


\section{Voorwoord}

Op 9 januari 1976 werd door Hare Majesteit Koningin Juliana de Rijksuniversiteit Limburg (de huidige Universiteit Maastricht) officicel voor geopend verklaard, met de wens dat deze universiteit, met haar "achtste" medische faculteit, zou bijdragen tot bloei van wetenschap en tot welzijn van de gemeenschap. De medische faculteit kreeg als basisfillosofie: aandacht besteden aan de opleiding tot arts werkzaam in het eerste echelon, nadruk leggen op probleemgestuurd leren in het onderwijs met aandacht voor attitudevorming, bij onderzoek streven naar samenwerking in thema's en een rol spelen in alle vormen van gezondheidszorg. De eerste 50 studenten startien hun studie reeds in september 1974 aan de medische faculteit te Maastricht. Hun onderwijs is probleemgestuurd dat wil zeggen dat het leerproces van de student in gang gezet wordt door problemen uit de praktiijk, afkomstig wit het beroepsveld.

Het volgen van onderwijs in de praktijk betekent dat de huisartspraktijken daartoe opengesteld dienden te worden. Dit gebeurde in onze praktijk al in een vroeg stadium, geïnitieerd door mijn toenmalige associé Toon Seelen, waardoor we kennis konden maken met de eerste stroom studenten en het praktisch medisch onderwijs in de huisartspraktijk (pmoH). In 1979 werd onze praktijk op het spoor gezet van registratie in de huisartspraktijk; namens de vakgroep huisartsgeneeskunde namen we deel aan het monitoringprojekt van Henk Lamberts. Deze ervaring op gebied wan registratie in de huisartspraktijk hebben we kunnen inbrengen toen de vakgroep huisartsgeneeskunde de ontwikkeling in gang zette naar een eigen netwerk van huisartspraktijken, die gegevens verzamelden voor onderzoek, het latere Registratie Netwerk Huisartspraktijken (RNH). In de loop van de jaren maakten we kennis met een groot aantal enthousiaste huisartsen, die lid werden van dit netwerk. Deze collegae hebben het mede mogelijk gemaakt dat het in dit proefschrift beschreven onderzoek uitgevoerd kon worden in hun praktijken. 



\section{Inhoudsopgave}

hoofdstuk

pagina

1 Inleiding 1

2 Het voorschrijven van geneesmiddelen zonder arts-patiëntcontact 13

3 Langdurig gebruik van slaap- en kalmeringsmiddelen in een huisarts- 23 praktijk

4 Benzodiazepinen. Karakteristieken van gebruik en gebruikers.

Een systematische analyse van literatuur betreffende eerstelijns-onderzock.

$5 \quad$ Interventies in de eerstelijn bij langdurig gebruik van benzodiazepinen.

Een literatuuronderzoek.

$6 \quad$ Van probleemstelling naar vaagstelling. 61

7 Methode van onderzoek, populatie-opbouw en procedure, data-analyse 69 en respons.

8 Slaap- en kalmeringsmiddelen in de huisartspraktijk:

gebruikswijze, redenen woor gebruik en kenmerken van de gebruikers.

9 Benzodiazepinen: de gebruiker en zijn huisarts.

Bijwerkingen, satisfactie, afhankelijkheid en stoppen, gezien door de bril van de gebruiker en zijn huisarts.

10 Psychosociale problemen en gebruik van slaap- en kalmeringsmiddelen

11 Lichamelijke gezondheid en gebruik van slaap- en kalmeringsmiddelen

12 Benzodiazepinegebruik in de huisartspraktijk.

Waarom laten we het (niet) zo? Exn exploratief onderzoek.

13 Beschouwing

14 Samenvatting

Dankwoord

Curriculum Vitae

Bijlagen 

hoofdstuk 1

\section{Inleiding}




\subsection{Introductie}

De komst wan de achtste medische faculteit in Maastricht (1974) met haar opdracht zich vooral te richten op de eerste lijn betekende dat huisartspraktijken opengesteld dienden te worden voor onderwijs en onderzoek. In het curriculum voor de opleiding tot basisarts werd een stage in de huisartspraktijk ingevoerd: het praktisch medisch onderwijs in de huisartspraktijk (pmolH). Een andere vorm van openstellen was het huisartsgastheerschap: aan bij de uniwersiteit werkzame artsen-stafleden werd de gelegenheid geboden om huisartsgeneeskundige vaardigheden bij te houden. Voor én of meer dagdelen werd zo'n uniwersitaire arts in de praktijk te werk gesteld; tevens had deze gast-arts een brugfunctie tussen universiteit en praktijk. Het openstellen van de praktijk had echter ook de consequentie dat er door studenten en gast-artsen kritisch gekeken werd naar patientenzorg en praktijkorganisatie. In de tachtiger jaren kwam in onze praktijk op die manier het onderwerp baliereceptuur aan de orde: op de simpele vraag "wat gaat er bij jullie aan baliereceptuur de deur wit?" konden we toen geen duidelijk antwoord geven. Dat was reden om in samenwerking met vijf andere praktijken de baliereceptuur door te lichten (hoofdstuk 2). De baliereceptuur betrof voor twee derde deel herhalingsrecepten, waarvan psycholeptica na middelen voor de tractus respiratorius op de tweede plaats stonden. Van deze psycholeptica vormden benzodiazepinen de hoofdmoot. De maatregel van de overheid om de receptuur van chronisch gebruikte geneesmiddelen aan banden te leggen (1995) bleek op het gebruik van benzodiazepinen geen reducerend effect te hebben. In de praktijk viel het op dat een deel van de benzodiazepinegebruikers heel regelmatig (dat wil zeggen maandelijks) hun recept. kwamen halen. Bij een ander deel was dit juist niet zo. Met dit inventariserend onderzoek was het spoor uitgezet natar verder onderzoek omtrent het gebruik van deze middelen in de huisartspraktijk.

In dit inleidend hoofdstuk worden de volgende zaken behandeld:

- de eigenschappen van slaap- en kalmeringsmiddelen: cen oriëntatie omtrent werking, farmacokinetiek, bijwerkingen en indicaties:

- algemene vragen omtrent het langdurig gebruik van deze middelen in de praktijk, mede gezien in het licht van het bovenvermelde circuit van baliereceptuur; een aanzet naar het uitgevoerde onderzoek;

- de opbouw van het proefschrift, met verwijzingen naar besproken onderwerpen in de diverse hoofdstukken. 


\subsection{Slaap-en kalmeringsmiddelen}

\section{Historie.}

Anxiolytica (kalmeringsmiddelen) en meer nog hypnotica (slaapmiddelen) żjn en worden veelvuldig toegepast. Slapen en waken zijn bij de mens immers belangrijke functies. Het slaapmiddel met de langste traditie is alcohol. In de oudheid werden veel extracten van planten en kruiden gebruikt, waarvan valeriaan nu nog het meest bekend is. In 1826 werden de broomzouten ontdekt, onder andere verwerkt in de slaapdrank Solutio Charcot. In 1869 werd chloralhydraat geïntroduceerd en in 1882 het paraldehyde. In 1903 werd het eerste barbituraat (barbital) gesynthetiseerd. Diverse barbituraten zijn sindsdien tot de zestiger jaren gebruikt met als indicaties slaapstoornissen en epilepsie. Bij de ontdekking van mephenesine (een urethaanderivaat, met een sterk spierverslappend effect) na de tweede wereldoorlog werd in Engeland de term 'tranquillisation' geintroduceerd. Uit mephenesine werd meprobamaat gesynthetiseerd, hetgeen in 1955 bij patiënten werd toegepast. ${ }^{1,2}$ Door Randall werden in 1959 testen gedaan met een benzodiazepinemolecuul, dat al eind $19 \mathrm{e}$ eeuw gesynthetiseerd was. Het bleek een middel met een veel krachtiger spierrelaxerend, hypnotisch, sedatief en anticonvullsief effect dan meprobamaat. In 1960 werd dit molecuul als chloordiazepoxyde (Librium), de eerste benzodiazepine, op de markt gebracht en in 1963 diazepam (Valium). Een structuurvariant met een sterker hypnotisch effect, het nitrazepam (Mogadon), volgde twee jaar later. Tegenwoordig zijn er vele benzodiazepinen beschikbaar, die hun populariteit danken aan hun effectiviteit en grotere veiligheid ten opzichte van de middelen van vóór de zestiger jaren."

Het gebruik van benzodiazepinen is niet in alle landen hetzelfde. Vit bevolkingsonderzoek verricht in 1981 bleek Nederland met $7,4 \%$ ten opzichte van de West-Europese landen het laagst te scoren in de prevalentie van gebruik van slaap en kalmeringsmiddelen. De prevalen tie van langdurig gebruik (langer dan 12 maanden) in Nederland was toen $1,7 \%$. Uit recentere gegevens over het totale gebruik in Nederland blijkt dat ongeveer $7 \%$ van de bevolking incidenteel een benzodiazepine gebruikt en $3 \%$ chronisch. In Nederland worden momenteel per jaar ongeveer 12 miljoen voorschriften voor benzodiazepinen afgegeven."

\section{Farmacologie.}

In het merendeel van de gevallen gaat het bij anxiolytica of hypnotica on dezelfde middelen, die op verschillende plaatsen in het zenuwstelsel hun aangrijpingspunten hebben. Het is volgens Van der Iaan beter om slaap- en kalmeringsmiddelen samen onder te verdelen naar de chemische structuur: benzodiazepinen, barbituraten en een restgroep (zie tabel 1). ${ }^{6}$ 
tabell. Overzicht van slap-en kalmeringsmiddelen. Oenenieke namen.

\begin{tabular}{|c|c|c|}
\hline Genugdromginer & bathinurited: & overige midulen \\
\hline $\begin{array}{l}\text { kortwerkend } \\
\text { triazolam } \\
\text { brotizolam } \\
\text { midazolam } \\
\text { middellang werkend } \\
\text { oxaxepam } \\
\text { temazepam } \\
\text { lormetazepian } \\
\text { loprazolam } \\
\text { alprazolam } \\
\text { Langwerkend } \\
\text { camazepam } \\
\text { bromazepam } \\
\text { ketazolam } \\
\text { nitrazepam } \\
\text { flunitrazepam (ow) } \\
\text { chlordiazejpoxyde } \\
\text { clobazepam } \\
\text { diazepam } \\
\text { nordazepam } \\
\text { clorazepinezuur } \\
\text { medazepam } \\
\text { prazepan } \\
\text { hallazepam } \\
\text { clonazepam } \\
\text { flurazepam } \\
\text { quazepam }\end{array}$ & $\begin{array}{l}\text { amobarbital } \\
\text { cyclobarbital } \\
\text { brallobarbital } \\
\text { butobarbital } \\
\text { secobarbital ( } O W \text { ) } \\
\text { vinylbarbital }\end{array}$ & $\begin{array}{l}\text { valeriaanpreparaten } \\
\text { valeriaan } \\
\text { oude middelen } \\
\text { chloralhydraat } \\
\text { gluthetimide } \\
\text { metacqualon (OW) } \\
\text { meprobamaat } \\
\text { hydroxyzine } \\
\text { hexapropynat. } \\
\text { clomethiazol } \\
\text { benzoctanine } \\
\text { chloormezanon } \\
\text { mefenoxalon } \\
\text { valnoctamide } \\
\text { nieutwe middelen/ } \\
\text { hypnotica } \\
\text { zopiclon } \\
\text { zolpidem } \\
\text { nieuwe middelen/ } \\
\text { anxiolytica } \\
\text { buspiron }\end{array}$ \\
\hline
\end{tabular}

bron: Wesseling e.a. algemene tarmacotherapie 1990

OW: middel valt onder opianwet:

Inmiddels zijn we bijna een decennium verder als Pepplinkhuizen weer uitgaat van een onderverdeling anxiolytica en hypnotica (tabel 2), waarbij voor de huidige toepassing van deze middelen een aantal oudere middelen zoals barbituraten wanwege hun bijwerkingen obsoleet is geworden. ${ }^{7}$ In dit kader worden de werking, farmacologie en bijwerkingen van alleen benzodiazepinen bespioken.

De werking van de benzodiazepinen berust op beïnvloeding van neurotransmitters in de synapsen tussen zenuwcellen van het centraal zenuwstelsel. Van de benzodiazepinen is bekend dat ze de binding stimuleren van gamma-aminoboterzuur (GABA), een neurotransmitter, aan zijn receptor, waardoor deze receptor geactiveend wordt en de exciteerbaarheid van de postsynaptische membraan vermindert. 6.8 Er zijn twee typen van GABA-receptoren (GABA ${ }_{A}$ en $\mathrm{GABA}_{\mathrm{B}}$ ) Benzodiazepinen hebben alleen effect op de $\mathrm{GABA}_{\mathrm{A}}$-receptoren. Van dit A-type GABA-receptonen zijn meerdere subtypen (onder andere $\alpha, \beta, \gamma$ en $\delta$ ) beschreven. 
tabel 2. Overzicht van de in Nederland gangbare slaap- en kalmeringsmiddelen. Generieke namen.

\begin{tabular}{|c|c|}
\hline generieke naam & generieke naarn \\
\hline $\begin{array}{l}\text { benzodiazepinen } \\
\text { alprazolam } \\
\text { bromazepam } \\
\text { chloordiazepoxyde } \\
\text { clobazepam } \\
\text { clonazepam } \\
\text { clorazepinezun } \\
\text { diazepam } \\
\text { ketazolam } \\
\text { lorazepam } \\
\text { medazepam } \\
\text { nordazepam } \\
\text { oxazepam } \\
\text { prazepam } \\
\text { temazepam }\end{array}$ & $\begin{array}{l}\text { bemzodiazepinen } \\
\text { brotizolam } \\
\text { flunitrazepam } \\
\text { flurazepam } \\
\text { lopprazolam } \\
\text { lormetazepam } \\
\text { midazolam } \\
\text { nitrazepam } \\
\text { ternazepam } \\
\text { triazolam }\end{array}$ \\
\hline $\begin{array}{l}\text { overige anxiolytica } \\
\text { buspiron } \\
\text { hydroxyzine } \\
\text { meprobamaat }\end{array}$ & $\begin{array}{l}\text { overige hypnotica } \\
\text { chloral hydraat } \\
\text { zolpidem } \\
\text { zopiclon }\end{array}$ \\
\hline
\end{tabular}

bron: Pepplinkchuizen e, a. Met Psychiätrisch Fomulativim 1997

Waarschijnlijk hebben zelfs combinaties van deze subtypen invloed op de excitatie van de postsynaptische membraan. ${ }^{8}$ Hierdoor kunmen ook nieuwe middelen gesynthetiseerd worden met specifieke affiniteit, zoals zopiclon (Imovane) en zolpidem (Stilnoct), de derde generatie slaapmiddelen en buspiron (Buspar), een anxiolyticum, waarvan het werkingsmechanisme nog niet volledig bekend is.

\section{Farmacokinetiek.}

Bij benzodiazepinen is de snelheid van in werking treden onder andere afhankelijk van de wijze van toediening, resorptie, en penetratie in de hersenen (lipofiliteit). Niet alle benzodiazepinen zijn direct actief, sommige moeten eerst in actieve metabolieten omgezet worden in het maag-darmkanaal of de lever. Op basis van hun halfwaardetijd zijn de benzodiazepinen te verdelen in kort-, middellang- en langwerkende middelen. ${ }^{6}$ De nieuwe hypnotica (zolpidem en zoplicon) dienen op grond van hun halfwaardetijd gerekend te worden tot kortwerkende slaapmiddelen. Ethnische afkomst, leeftijd, geslacht en gezondheid hebben invloed op het metabolisme van benzodiazepinen (dat betreft zowel oxydatie als conjugatie). ${ }^{9-11}$ Tevens kan dit metabolisme door diverse geneesmiddelen worden vertraagd (bijvoorbeeld door cimetidine, ranitidine, oralle anticonceptie, disulfram, isoniazide, propanolol) of versneld (bijvoorbeeld door fenytoine, carbamezapine, rifampicine, barbituraten, alcohol en roken). $6,12,13$ 


\section{Bijwerkingen.}

Van de oudere middelen is bekend dat ze niet alleen bijwerkingen hebben, maar met name ook lichamelijke afhankelijkheid kunnen veroorzaken. Hoewel de bijwerkingen van benzodiazepinen voor zover bekend zelden dramatisch of fataal zijn, kunnen ze ongemerkt het gedrag en het functioneren van de gebruiker beinwloeden. Er zijn bijwerkingen beschreven in de zin van sedatie (sufheid, verminderd concentratievermogen, afgenomen reactiesnelheid en kritisch vermogen, hang-over bij slaapmiddelen), amnesie (verlies van herinnering), spierverslapping (moeheid, spierzwakte) paradoxale reacties (agitatie, agressie, suicide, nachtmerries), ademhalingsdepressie en afhankelijkheid en misbruik. ${ }^{6,7}$ Door gewenning ontstaan verder rebounden ontwenningsklachten bij stoppen. ${ }^{7.14}$ Het eerste bericht van afhankelijkheid dateent van 1963. Hollister beschreef toen ontwenningsreacties op chloordiazepoxyde. ${ }^{15}$ Pas in de tachtiger jaren werd er meer aandacht besteed aan tolerantie, afhankelijkheid en ontwenningsreacties. In Engeland (1985) werd een restrictielijst ingevoerd; in Amerika, in de stad New York (1989), moesten benzodiazepinerecepten speciaal in drievoud worden uitgeschreven. ${ }^{16,17}$ De eerste duidelijke waarschuwing in de Nederlandse literatuur stamt uit $1984{ }^{18}$ Het overschakelen van langwerkende naar kortwerkende slaapmiddelen vond toen geleidelijk zijn ingang. Verberk beschreef een dergelijke omschakeling in zijn praktijk in $1992 .^{19}$ In 1994 werd zelfs een benzodiazepine (flunitrazepam) onder de Opiumwet geplaatst.

De nieuwe slaapmiddelen (zogenaamde non-benzodiazepinen) hebben minder reboundverschijnselen en er treedt geen tolerantie op voor het hypnotisch effect. ${ }^{7,20,21}$ Buspiron, een nieuwe anxiolyticum, kent geen ontwenningsverschijnselen. 5

\section{Indicaties. 6.7}

De generieke namen van de huidige (1997), in Nederland gangbare, anxiolytica en hypnotica zijn weergegeven in tabel 2 .

Er zijin diverse indicatiegebieden te onderscheiden voor de benzodiazepinen. De voornaamste in de psychiatrie zijn:

-toestanden gepaard gaande met angst, spanning, vegetatieve klachten, -situatieve paniek (alleen alprazolam en clonazepam),

-delirante syndromen, met name alcoholontwenning (diazepam en chloordiazepoxyde, clorazepinezuur),

-speciele indicaties zoals clonazepam bij manische syndromen, en lorazepam bij akathisie (onvermogen tot stilzitten als bijwerking van antipsychotica),

- slaapstoormissen (NHG-standaard). ${ }^{22}$

Naast de psychische/psychiatrische stoornissen worden de benzodiazepinen ook gebruikt bij neurologische ziektebeelden (onder andere spierrelaxans, anti-epileptica) en in de anaethesiolo- 
gie. Meprobamaat: wordt behalve als axiolyticum ook als spierrelaxans gebruikt.

Valeriaan(extract) wordt meestal gebruikt als rustgevend middel en in hogere doseringen als slaapmiddel.

tabel 3. In Nederland gangbare slaap-en kalmeringsniddelen, volgers advies van Centraal Medisch Pharnacer. tische Commissie (CMPC). Het farmacon (generieke naam) en zijn specialite.

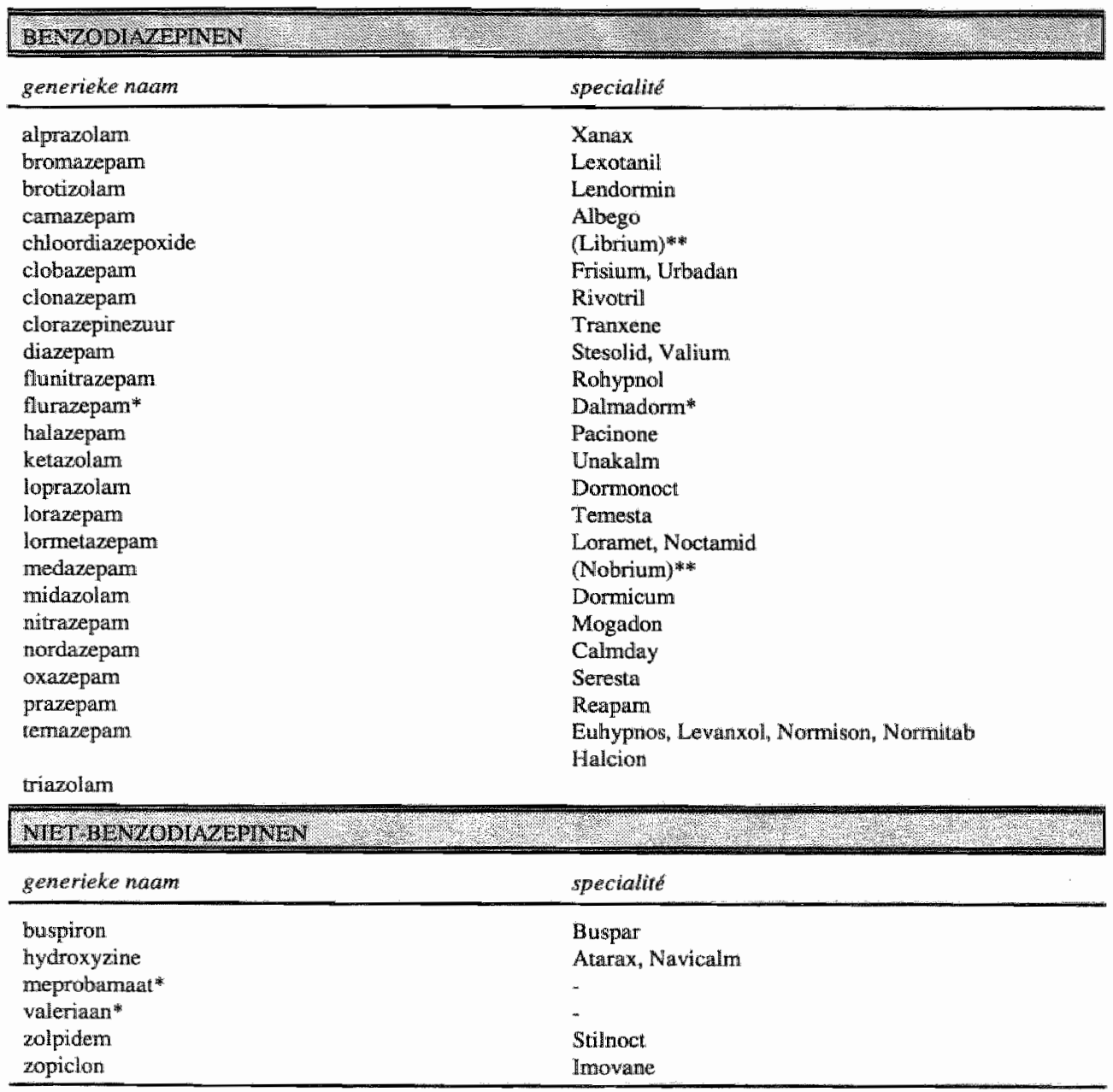

bron: Farmacotherapeuti weth Kompasi 1997

* yolgens advies CMPC op farmacotherapeutische gronden niet meer voorschrijwen

** als specialité niet meer te verkrijgen 
De benzodiazepinen hebben, afhankelijk van de dosis, verschillende effecten. Als de dosis verhoogd wordt, is achtereenvolgens een anxiolytisch effect te zien, dan een anticonvulsief, daarna een spierverslappend en vervolgens een sedatief en hypnotisch effekt. Ten gevolge hiervan zijn specialités in de handel met dezelfde grondstof, maar verschillende doses. Er zijn echter ook verschillende specialités die dezelfde samenstelling hebben. (tabel 3 ). ${ }^{23}$

\section{Slaap - en kalmeringsnmiddelen in de praktijk}

Uit praktijkervaring blijkt dat slaap-en/of kalmeringsmiddelen (voomamelijk benzodiazepinen) door een vaste kern van patienten langdurig gebruikt worden. Centraal bij dit fenomeen statan de vragen: watarom bljuen sommige patienten deze middelen gebruiken en andere niet; waarom verschilt de mate van gebruik binnen de groep langdurig gebruikers, te oordeLen naar de vraag om herhalingsreceptuur? Is het langdurig gebruik afhankelijk van te yerwerken problematiek of is er sprake van een kwetsbare patiënt, die deze middelen nodig heeft om te kumnen functioneren? Betekent langdurig gebruik ook dat er onnodig gebruik plaatsvindt? Wetende dat er van deze middelen mogelijk dempende effecten en schadelijke effecten zijn, is er dan een dilemma voor de voorschrijvende arts alls de (langdurig) gebruiker om een herhaalrecept wraagt?

Dit waren de overwegingen, die ons tot nader onderzoek brachten.

\subsection{Opbouw van het proefschrift.}

\section{Het oriênterend vooronderzoek}

\section{Baliereceptruur}

Geintrigeerd door vragen van collega-artsen over het fenomeen baliereceptuur werd cen onderzoek gedaan naar het voorkomen van dleze vorm van receptuur. Resultaten zijn beschreven in hoofdstuk 2.

\section{Pilotonderzoek}

De vraag rijst waarom mensen slaap-en kalmeringsmiddelen slikken. Wat is de oorzaak van slecht slapen en nervositeit? Als je eenmaal begint met slikken word je dan van lieverlee chronisch gebruiker? Een eerste orièntatie omtrent deze vragen (in de vorm van een pilotstudie) werd uitgevoerd in eigen praktijk. (hoofdstuk 3) 


\section{Literatuuronderzoek}

Naast het pilotonderzoek in eigen praktijk werd tevens in de literatuur gezocht naar karakteristieken van gebruikers van deze middelen zoals gebruikspatroon, indicatiestelling en profiel van de gebruiker.(hoofdstuk 4)

Eigen ervaringen met het begeleiden van patiënt-gebruikers bij pogingen tot stoppen waren niet hoopgevend. We waren daarom nieuwsgierig naar ervaringen van collega's in de eerste lijn en zijn op zoek gegaan naar eerstelijns studies omtrent interventies bij langdurig gebruik van benzodiazepinen.(hoofdstuk 5)

\section{Het onderzoek.}

\section{Het multicenter onderzoek}

In onze praktijk deed de computer in 1988 zijn intrede, we werden lid van het RegistratieNet Huisartspraktijken (RNH) van de Universiteit Maastricht. Dit netwerk levert een geautomatiseerd onderzoeksbestand waarin per ingeschrevene naast patiënt-achtergrondvariabelen ook een probleemlijst is opgenomen, als onderdeel van de medische verslaglegging in de huisartspraktijk. ${ }^{24}$ In 11 praktijken van het RNH werd in 1993 een multicenter onderzoek gestart onder een steekproef van gebruikers van slaap- en kalmeringsmiddelen en een controlegroep op zoek naar karakteristieken van gebruik(ers) in de eerste lijn. Informatie werd verzameld via postenquêtes, waarin patiënten ondervraagd werden over het gebruik van slaap- en/of kalmeringsmiddelen. Tevens werd hun huisarts geënquêteerd omtrent diens visie op het gebruik door zijn patiënten. Naast deze enquêtes werd gebruik gemaakt van gegevens (patiënt-achtergrondvariabelen en probleemlijsten) in het RNH-bestand van de deelnemende praktijken. De vraagstelling en methode van onderzoek zijn beschreven in hoofdstuk 6 en 7 .

Omdat in de literatuur nogal verschillende definities gehanteerd worden omtrent langdurig en kortdurend gebruik van benzodiazepinen is een theoretisch gebruiksmodel ontwikkeld. Op basis van dit model is gezocht naar verschillen tussen de diverse categorieën gebruikers met betrekking tot demografische kenmerken, gebruikte middelen, wijze van verstrekking, klacht(en) waarvoor het middel wordt gebruikt, gepercipieerde oorzaak van de klacht, persoonskenmerken, probleemverwerking en gezondheid (hoofdstuk 8).

In twee onderzoeken in Nederlandse praktijken werd een hoge satisfactiegraad gemeten ten aanzien van het gebruik van benzodiazepinen, ${ }^{25,26}$ overeenkomend met de bevindingen van Salinsky in $1987 .{ }^{27}$

Is deze tevredenheid terug te vinden in bepaalde categorieën gebruikers? Als men tevreden is, 
zal men waarschijnlijk ook niet zo gaw besluiten te stoppen. Hoe denkt de patiënt-gebruiker hierover en wat is de mening van de huisarts? Dit onderwerp komt aan de orde in hoofdstuk 9.

Op basis van de indeling in categorieën volgens ons model zijn deze categorieën gebruikers in de hoofdstukken 10 en 11 vergeleken met niet-gebruikers ten aanzien van psychosociale en gezondheidskenmerken.

Benzodiazepinegebruik, laten we het zo?

Elke praktijk heeft zijn vaste kern van langdurig gebruikers. De huisarts is zich daarvan bewust. Moeten we ons daarover zorgen maken? In Nederland is het chronisch gebruik immers laag in vergelijking met andere landen. ${ }^{3,28}$ Lagro-Janssen stelde dat de huisarts er niet wakker van zou hoeven te liggen. Misschien is de patiënt-gebruiker in balans dankzij het benzadiazepinegebruik. Wél pleit ze voor het voorkómen van langdurig gebruik. ${ }^{28}$ Wanneer zou een huisarts dan wel moeten interveniëren? In de literatuur konden we niets vinden over onderzoek naar selectiecriteria van de huisarts-practicus om al dan niet over te gaan tot individuele interventie. In vier Maastrichtse praktijken werden de huisartsen van langdurig gebruikers geènquêteerd omtrent hun mening over de vraag of de patiënt al dan niet benaderd zou moeten worden met het verzoek zijn medicatie te stoppen of te minderen.(hoofdstuk 12)

\section{Beschouwing}

Tenslotte worden in hoofdstuk 13 de onderzoeksresultaten in onderlinge samenhang nader beschouwd. 


\section{Lilterature}

Hoes MJAIM. Slaap en slaapstoomissen. Van Palmwijn tot 5tilnocil (zolpidem) aflevering 1, ded I De papieren visite 1993: $18: 5 \mathrm{~m}$

Hoes MAMM. Shaap en shaapstoomissen. Van Palmwijn tot Stilnoet (zolpidem) aflevering 1. deel 2 De papieren visite 1993:19:7-9

Balter MB, Manheimer DI, Mellinger GD, Uhlenhuth EH. A cross-national comparison of anti-anxiety/sedative drugs use. Curr Med Res Opin 1984; 8(suppl 4): 5-20

Willigenburg van APP. Franssen EAM, Lebret E, ea. Geneesmiddelengebruik als indicator voor de effecten van milieuverontreiniging; studie in de regio Schiphol. Utnecht: Universitent van Utrecht, Bilthowen: Rijksinsituut voor Volksgezondheid en Milieu. 1996

Anonymus. Data en Feiten. Kostenonnwikkeling wan de farmacentische thulp. Stichting Fatmarceutische Kengetallen. 1996

Laan wan der JW. Hypnotica en anxiolytica. In: Wesseling H. e.a. Algemene Farmacotherapie 1990 $174-193$

Pepplinkhuizen L, Verhoeven WMA, Does vam der E, Sitsen JMA. Het Psychiatrisch Formularium, een praktische leidraad. Rotterdam 1997. Erasmus Publishing. ISBN 90-5235-093-0

9 Lin KM, Poland RE, Smith MW, Strickland TL, Mendoza R, Pharmacokinetics and other related factors affecting psychotropic responses in Asians. Psychopharmacology Bulletin 1991; 27: 427-39 col Exp Ther 1980; 215:86-91

11 Macleod SM, Giles HGi, Bengert B. Age and gender related diflerences in diazepam pharmacokinetics. I Clin Pharmacol 1979; 19: 15-9

\section{0: $513-7$}

Abernethy DR, Greenblat DJ, Ochs HR, Shader RI. Benzodiazepine drug-dnug interactions commonly occurring in clinical practice. Curr Med Res\& Opinion 1984; 8(suppl 4): 80-93

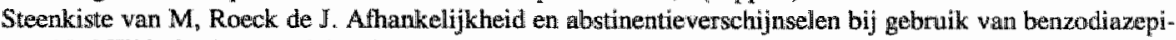
nen. Ned Tijdschr Geneeskd 1986; 130(27): 1224-7

Hollister LE, Motzenbecker EP, Degan RO. Withdrawal reactions from chlordiazepoxyde (Wibrium). Psychopharmacologica 1963; 2:64-8

16. DHHS The restricted list of NHS drugs Lancet 1985 ; i: 531

17 New York State Deparment of Health, Division of Public health Protection. New York State's regulating placing benzodiazepires on triplicate prescription: the first year 1989, NY State Department of Health, 1990.

18 Laan van der JW. Afhankelijkheid wan benzodiazepinen: onvang, risico's en eventuele verschillen fussen de nuddelen onderling. Med Tijdschr Oeneeskd 1984; 128:817-9

19 Verberk $\mathbb{H}_{m}$ Post D. Benzodiazepinen im een huisantspraktijk. Medisch Contact 1992; 49:1453-5

20 Freeman $H$, Puech AJ, Roth $T$, e.a. Zolpidem: an update of its pharmacological properties and therapeutic place in the nasnagement of insomnia. 1996 Elsevier Paris. ISBN 2-906077-99.2

21 Anonymus. Formulamium Into Nümegen. 1996; 9 (2):5-6.

22 Anonymus NHG-standaard Slapelloosheid en Stapmiddelen. Huisarts Wet 1992; 35(5): 212-9

23 Anonymus. Farmaco-therapeutisch Kompas 1997, Ziekenfondsraad, Amsterdam.

24 Metsemakers JFM. Höppener $\mathbb{P}$, Knotineris JA, Kocken. RI, Limonard CBG. Computerized haelth infomation in the Netherlands: a registration network of farmily practices. Brit J Gien Pract. 1992: 42: $102-6$

Vissers FHJ A, Knotmenas JA, Van der Gitinten RF, Van der Horst FCEM, Langdurigg gebruilk van wanen kalmeringsmiddelen in een huisartspraktijk. Huisarts Wet 1993; 36(12): 405-8

26 Lagrowanssen ALM, Liberton IJW, Benzodiazepinen: profielen van chromische gebruikerg in wen huisartspraktijk. Ned Tijdschr Geneesk 1993; 39: 1969-73

27 Salinsky JW, Doré CJ. Charactersitics of long-term benzodiazepine users in general Practice. I R Coll Gen Pract $1987 ; 37: 202-4$

28 Lagromanssen T. Benzodiazepinen en de gemoedstust wan de huisants [Communtaar]. Huisarts Wet 1993; $36(12) ; 402-4$ 

hoofdstuk 2

\section{Het voorschrijven van geneesmiddelen zonder arts-patiëntcontact}

Dit hoofdstuk is gepubliceerd als:

Plagge H.W.M, Vissers F.H.J.A, Pouls K, De Geus C.A. Het voorschrijuen wan geneesmiddelen zonder arts-patiënt contact. Huisarts Wet 1988; 31: 120-123 


\section{Abstract}

Objective. To investigate appearance and kind of desk prescriptions in general practice.

Setting. Five general practices, all members of the "Registratie Netwerk Huisartspraktijken" (RNH) of the University of Maastricht.

Method. Inquiry by telephone among participating doctors; submitting a questionnaire to all patients asking a prescription at the reception desk during four weeks.

Results. The study was carried about drug prescriptions without a doctor-patient encounter. About 30 percent of all prescriptions were asked at the reception desk. Nearly 75 percent of those were repeat prescriptions for drugs that in the past were mostly initiated by the general practitioner. Prescriptions usually asked at the desk were psycholeptics, drugs for the respiratory or circulatory tract, for the skin and analgetics. A systematic registration of those desk prescriptions was not carried out.

Conclusion. Issuing large numbers of repeat prescriptions at the desk may create a large group of patients who rarely see the doctor but nevertheless use (much) medication. A large amount of desk prescriptions encourage a good registration, especially for psycholeptic drugs.

Key words. family practice, desk prescription 


\subsection{Inleiding}

Elke huisarts schrijft dagelijks geneesmiddelen voor. In het merendeel van de gevallen is dit het resultaat van een consultatie. Daamaast worden vrijwel dagelijks aan de balie recepten verstrekt zonder dat de huisarts contact heeft gehad met de patiènt. Dankzij deze 'balierecepten' wordt het aantal consulten per patiënt per jaar aamzienlijk beperkt. Afschaffing van de baliereceptuur zou leiden tot een verhoging van het aantal consulten met 16 tot 50 procent. ${ }^{1,2}$ Aan het verstrekken van recepten aan de balie kleven echter ook nadelen:

- het risico van inadequate recepten; in een Engelse studie gold dat voor 40 procent van de recepten, die niet door de paraferende huisarts waren geschreven; ${ }^{3}$

- het risico van geneesmiddeleninteracties; dit risico wordt groter naarmate de huisarts minder zicht heeft op het geneesmiddelengebruik van de patiënt;

- het risico van geneesmiddelenverslaving, met name aan neuroleptica; 4

- het risico dat sommige patiënten elk contact met de huisarts ontlopen." Vermoedelijk worden balierecepten in veel praktijken niet geregistreerd. Er zijn wel systemen om een zo volledig mogelijk overzicht te houden over het totale medicatiegebruik - prescriptiekaarten, duplicaatreceptuur, geneesmiddelenkaarten en herhalingsregisters ${ }^{6-9}$ - maar in hoeverre deze systemen in de huisartspraktijk worden gehanteerd is nog de vraag. $\mathrm{Nu}$ steeds meer huisartspraktijken gaan automatiseren, lijkt echter de computer - en in de toekomst wellicht ook de 'smart-card' - hulp te bieden bij de medicatiebewaking. ${ }^{10,11}$

Binnen de praktijken van het Registratienet Huisartspraktijken (RNH) van de Rijksuniversiteit Maastricht is een oriënterend onderzoek verricht met als uitgangspunt de volgende vragen:

- Welke omvang heeft het verschijnsel "balierecepten"?

- Worden er systemen gehanteerd om deze recepten te registreren?

- Voor wie zijn de balierecepten bestemd?

- Waarom geven patiënten de voorkeur alan een balierecept?

- Hoe groot is het aandeel van de nieuwe en de herhalingsrecepten in de totale baliereceptuur?

- Welke soorten medicijnen worden via de balie voorgeschreven?

- Voor welke klachten worden balierecepten gevraagd?

- Zijn er verschillen tussen de balliereceptuur en de recepten die tijdens de consulten worden voorgeschreven?

\subsection{Methode}

Aan het onderzoek namen acht huisartsen deel, verdeeld over een solopraktijk, een associaticpraktijk, en drie gezondheidscentra. De totale praktijkpopulatie bedroeg ongeveer 20.000 patiënten. 
De eerste fase van het onderzoek bestond uit een welefonische enquête in december 1986 onder de deelnemende huisartsen. Vervolgens is in januari 1.987 een vragenlijst woorgelegd aan alle patiènten, die gedurende de normale praktijkuren aan de assistente om een recept vroegen. Ook zijn toen alle prescripties tijdens de directe arts-patiënt contacten geregistreerd. Onder een recept verstaan we in dit verband een onder $R /$ afgegeven voorschrift van een enkelvoudig of samengesteld geneesmiddel. Op de door de medicus gebruikte receptenbriefjes kunnen dus verscheidene recepten tegelijk worden uitgeschreven.

Na afloop van elke werkdag zijn alle: voorgeschreven recepten door de huisartsen gecodeerd met behulp van de 'EPHAMRA'-classificatie, een classificatiesystecm voor farmacologische middelen. ${ }^{12}$

De klachten en ziekten waarvoor aan de assistente om een recept was gevraagd, werden gecodeerd met behulp van de Internationall Classification of Primary Care (ICPC). ${ }^{13} \mathrm{De}$ hoofdustwkindeling van beide classificatiesystemen loopt overigens niet geheel paralel.

\subsection{Resultaten}

Omvang. Alle huisartsen zeiden dagelijks recepten voor te schrijven zónder dat ze contact hadden gehad met de patiënt. Het aandeel van de recepten, die op deze wijze worden woorgeschreven, werd door hen geschat op gemiddeld 30 procent (variërend van 5 tot 50 procent) van de totale receptuur.

In de vier weken van materiaalverzameling werd in total 1335 maal aan de balie om éen of meer recepten gevraagd. In 293 gevallen werd geen vragenlijst ingevuld: 46 mensen wensten geen medewerking te verlenen en 247 mensen vulden het formulier niet in om een andere reden, zoals analfabetisme van de aanvrager of communicatieproblemen bij allochtonen. Verder speelde een rol dat medewerkers van sommige bejaardenhuizen gewoon zijn voor een aantal patiènten tegelijk recepten te vragen.

Trijdens de 1042 overige keren dat aan de balie om een recept is gevraggd, werden 1468 medicamenten voorgeschreven. In het merendeel van de gevallen werd én medicament gevraagd en in ruim een kwart van de gevallen twee (tabel 1). Gemiddeld werd per aanvraag 1,4 medicament voorgeschreven. 
tabel 1 .

Aantal medicamenten dat aan de balie werd woorgeschrewen $(\mathrm{N}=1042)$

\begin{tabular}{lccc}
$\begin{array}{l}\text { aantal medicamenten } \\
\text { per aanvraag }\end{array}$ & $\begin{array}{c}\text { aantal } \\
\text { aanvragen }\end{array}$ & $\begin{array}{c}\text { percentages } \\
\text { van het totaal }\end{array}$ & $\begin{array}{c}\text { cumulatief aurntal } \\
\text { medicamenten }\end{array}$ \\
\hline 1 & 706 & 68 & 706 \\
2 & 266 & 26 & 1238 \\
3 & 54 & 5 & 1400 \\
4 & 12 & 1 & 1448 \\
5 & 4 & 0,4 & 1468 \\
\hline
\end{tabular}

Naar aanleiding van de directe arts-patiënt contacten zijn in dezelfde periode in totaal 3837 recepten uitgeschreven. Het aandeel van de gedocumenteerde balierecepten in de totale receptuur bedroeg dus ruim 26 procent. Het werkelijke aandeel zal waarschijnlijk hoger liggen.

Registratiesysteem. Alle huisartsen blijken dagelijks recepten voor te schrijven zónder dat ze contact met de patiënt hebben gehad. De assistentes proberen de aanvragen voor balierecepten zelfstandig af te handelen aan de hand van richtlijnen wan de huisarts, zeker als het om herhalingsrecepten gaat.

In alle praktijken wordt op een of andere wijze genoteerd dat er aan de balie een recept is afgegeven en wat de inhoud van dat recept is (bijvoorbeeld door een notitie in de status of op de groene kaart). Dat gebeurt echter niet altijd systematisch en evenmin bij elk recept. Er blijken patiëntgebonden en receptgebonden redenen te zijn om de balierecepten te registreren, zoals het particulier verzekerd zijn van de patiënt, medicatiemisbruik en het soort receptuur.

Voor wie bestemd? Van de balierecepten was 48 procent bestemd voor de aanvrager zelf en 43 procent voor een familielid. De resterende groep bestond uit aanvragen voor buren en anderen. In een klein aantal gevallen was deze vraag niet ingevuld.

Reden voorkeur. De patiënten vroegen in de meeste gevallen om een recept aan de balie, omdat zij een herhaalrecept wilden hebben, of omdat voor hun klacht naar hun oordeel geen doktersbezoek noodzakelijk was (tabel 2).

tabel 2.

Redenen om het recept aan de balie te wragen. Afgeronde percentages. (N=1042) 
Nieuwe en herhalingsrecepten. Door de huisartsen werd in de telefonische enquête het aandeel van de nieuwe recepten in de groep balierecepten geschat op 25 á 50 procent, waarbij men voomamelijk dacht aan recepten met betrekking tot de ademhalingsorganen en werbandmiddelen. Bij de herhalingsrecepten werd het aandeel van de "specialistenrecepten" hoog geschat: men dacht dat het hifer voomamelijk zou gaan om medicamenten voor hart en bloedsomloop, medicamenten voor ademhalingsorganen, huidpreparaten, anticonceptiva en psycholeptilica.

In feite bedroeg het percentage nieuwe recepten dat aan de balie werd voorgeschreven, slechts 20 procent. Van de aan de balie uitgeschreven herhalingsrecepten was 69 procent volgens de patiënten voorafgegaan door een eerder voorschrift van de huisarts, en ruim 20 procent door een voorschrift van de specialist. In 0,7 procent van de gevallen werd de assistente als eerste voorschrijver van een recept genoemd: waarschijnlijkk gaat het hier om recepten, die ook de eerste keer dat ze werden voorgeschreven aan de balie zijn gevraagd en verkregen. In de resterende gevallen was de eerste voorschrijver een ander $(2,5$ procent $)$ of onbekend $(7,5$ procent).

Soorten medicijnen. De belangrijkste groepen waarvoor aan de balie een herhalingsrecept werd afgeleverd, waren psycholleptica, medicamenten voor hart en bloedsomloop, huidpreparaten, medicamenten voor ademhalingsorganen en verbandmiddelen (tabel 3).

tabell 3. Verdeling van de woorgeschrewen medicamenten (herhaling/nieuw/onbekend).

Affgeronde kolompercentages.

EPHAMRA-hoofdstuken

herhaling neuw onbekend medicamenten (voor): $n=1092 \quad n=290 \quad n=86$

\begin{tabular}{|c|c|c|c|c|}
\hline A & maag/durnstel sel en stofwisseling & 8 & 6 & 12 \\
\hline B & bloed bn blodvormende organen & 1 & 1 & 1 \\
\hline $\mathrm{C}$ & hart an blow dsomloop & 14 & 2 & 19 \\
\hline $\mathrm{D}$ & huid & 12 & 7 & 5 \\
\hline$G$ & Larogenitan stelsel (incl geslachtshormonen / iucd) & 9 & 2 & 6 \\
\hline$H$ & systemische hormoonpreparaten (excl gesl.homonen) & 1 & 0 & $\mathbb{1}$ \\
\hline j & systemische andi-infectie medicamenten & 1 & 5 & 0 \\
\hline$L_{\omega}$ & cytostation & 0 & 0 & 0 \\
\hline M & bewegingsapparaat & 5 & 3 & 5 \\
\hline$N_{2}$ & arablgetica & 6 & 14 & 7 \\
\hline N5 & psycholaptices & 21 & 5 & 15 \\
\hline Noy & overige medicamenten voor zenuwstelsel & 3 & 1 & 0 \\
\hline p & parasiticident & 0,4 & 2 & 0 \\
\hline $\mathbb{R}$ & adembilingsstelsel & 11 & 49 & 22 \\
\hline$\$$ & zintuigen & 1 & 1 & 1 \\
\hline $\mathrm{V}$ & owerige medicamenten & 1 & 1 & 0 \\
\hline Z & owerige niet-farmaceutische middelen (o.a. verband) & 6 & 2 & 7 \\
\hline
\end{tabular}


Dit stemt goed overeen met het beeld dat de huisartsen hierover hadden.

Uit tabel 3 blijkt verder dat de nieuwe recepten die via de balie werden voorgeschreven, niet beperkt bleven tot de door de huisartsen genoemde hoestdrankjes en verbandmiddelen. Ook als griepmiddel voorgeschreven analgetica, huidpreparaten en preparaten voor spijsverteringsstelsel en stofwisseling bleken een bellangrijk aandeel te hebben.

Klachten. Ruim 9 procent van de halers van een recept aan de balie wist niet voor welke klacht het preparaat was bedoeld. In de overige gevallen werd vaak geen gespecificeerde diagnose of klacht genoemd, maar een omschrijving als 'voor het hart' of 'zenuwen". Het ging hier vooral om klachten en ziekten uit de categorie luchtwegen, psychische stoomissen, huid en hart/vaatstelsel (tabel 4).

tabel 4. De klachten en ziekten waarwoor aan de balie om cen recept werd gevrangd.

Afgeronde kolompercentages $(N=1468)$

ICPC-hoofdstukken

\begin{tabular}{|c|c|c|}
\hline A & algerneen en niet gespecificeerd & 4 \\
\hline $\mathrm{B}$ & bloed en bloed vormende organen & $\mathbb{1}$ \\
\hline $\mathrm{D}$ & maag-darmstelsel & 6 \\
\hline $\mathrm{F}$ & $\log$ & l \\
\hline $\mathrm{H}$ & oor & 0,3 \\
\hline K & hart en vagatstelsel & 10 \\
\hline $\mathbb{L}$ & bewegingsapparat & 4 \\
\hline $\mathbf{N}$ & zenuwstelsel & 5 \\
\hline $\mathrm{P}$ & psychische stoornissen & 17 \\
\hline $\mathbb{R}$ & adem nalingsstetsel & 20 \\
\hline$\$$ & huid en subcutan weersel & 11 \\
\hline $\mathrm{T}$ & endocriene, metabole en voedingsziekten & 1 \\
\hline U & urinewegen & 3 \\
\hline W & zwangerschap, bevalling, krammed, articonceptie & 6 \\
\hline$X$ & geslachtsorganen en borsten vrou w & 1 \\
\hline$y$ & geslachtsorganen en borsten mar & 0,1 \\
\hline \multirow[t]{2}{*}{ Z } & sociale problemen & 0,1 \\
\hline & anbekend & 9 \\
\hline
\end{tabular}

Verschillen. In hoofdlijnen waren ar geen verschillen te constateren tussen de baliereceptuur en de recepten die tijdens de consulten werden voorgeschreven. Een uitzondering vormde de groep psycholeptica: een aandeel van 18 procent in de baliegroep tegen 6 procent in de consultgroep. Een andere uitzondering was de groep systemische anti-infectiepreparaten met een aandeel van 1 procent in de baliegroep en 7 procent in de consultgroep (tabel 5). 
tabel 5. Verdeling wan woongeschireven medicamenten (aun de balieltijdens hei consult).

Afgeronde kolompercentages.

\begin{tabular}{|c|c|c|c|}
\hline \multicolumn{2}{|c|}{ EPHAMRA-hootdstukken } & \multirow{2}{*}{$\begin{array}{l}\text { aan de } \\
\text { balie } \\
\mathrm{n=1468} \\
8\end{array}$} & \multirow{2}{*}{$\begin{array}{c}\begin{array}{c}\text { dijdens } \\
\text { consuli } \\
n=3837\end{array} \\
10\end{array}$} \\
\hline A & marafdatingtelsel en stofwisseling & & \\
\hline $\mathrm{B}$ & bloed en bloedvommende organer & 1 & 1 \\
\hline $\mathrm{C}$ & hatirt en bloedsomiloop & 12 & 10 \\
\hline $\mathrm{D}$ & huid & 10 & 13 \\
\hline $\mathrm{G}$ & urogenitaal stelsel (inel geslachtshormonen / udud) & 7 & 8 \\
\hline $\mathrm{H}$ & systemische homoonpreparaten (excl gesl.homoner) & 1. & 1 \\
\hline $\mathfrak{J}$ & systemische anti-infectie medicamenten & 1 & 7 \\
\hline $\mathrm{L}$ & cytostatica & 0 & 0 \\
\hline M & bewegingsapparat & 5 & 8 \\
\hline $\mathrm{N2}$ & aralgetica & 8 & 7 \\
\hline N5 & psycholeptica & 18 & 6 \\
\hline N7 & overige medicanenten woor zenuwstelsel & 3 & 1 \\
\hline$P$ & parasulticiden & 1 & 0,4 \\
\hline $\mathbf{R}$ & ademhalingsstelsel & 19 & 20 \\
\hline S & zintuigen & 1 & 4 \\
\hline $\mathrm{V}$ & overige medicamenten & 1 & $\Perp$ \\
\hline$Z$ & overige niet-farmaceu tische middelen (o.a. verband) & 5 & 3 \\
\hline
\end{tabular}

\subsection{Beschouwing}

Uit het onderzoek blijkt dat de huisartsen vór de start van het onderzoek een goed overzicht hadden van de omvang van het verschijnsel baliereceptuur. In de meeste praktijken wordt echter slechts een deel van de balierecepten geregistreerd, vaak op basis van ad hoc beslissingen.

Het aandeel van aan de balie voorgeschreven recepten in dit onderzoek is ongeveer 32 procent, hoger dan de vit de literatuur bekende 18 en 27 procent. ${ }^{3.4}$ Hierbij moet rekening gehouden worden met het feit dat het onderzoek plaatsvond in januari: mogelijk waren met name de luchtweginfecties oververtegenwoordigd en zijn er relatief weinig herhalingsrecepten voorge schreven (namelijk als men in december in verband met eigen bijdrageregeling (knakenkaart) veel extra medicamenten had gevraagd). Verder kan de uitval van veel recepten voor bewoners van bejaardentehuizen hebben geleid tot enige vertekening; in deze groep bevinden zich immers veel hoogbejaarden, die relatief veel medicamenten gebruiken. 8,14

De belangrijkste reden om aan de balie om een recept te vragen, blijkt te zijn dat het om een herhalingsrecept gaat. Ook een rol speelt het oordeel van de patient dat het om een klacht/ziekte gaat waarvoor men de huisarts niet wil raadplegen. Uit de literatuur is bekend dat patiénten steeds minder de neiging hebben de arts te bezoeken naarmate ze vaker een herhalingsrecept voorgeschreven krijgen. ${ }^{5}$ Het afgeven van grote aantallen herhalingsrecepten aan de balie kan op deze manier leiden tot het ontstaan van een groep patiënten die de huisarts 
zelden bezoekt, maar toch (veel) medicatie gebruikt. In dit onderzoek gaat het om ruim 67 procent van de aan de balie afgegeven recepten.

Dat controle door de arts niet of niet goed mogelijk is, bij het aan de balie door assistentes woorschrijven van recepten, zal duidelijk zijn. Het bewaken van het medicatiegebruik van patiènten is, zelfs als men precies registreert wat de patiënt gebruikt, al een moeilijke taak. Het afgeven van grote hoeveelheden medicamenten aan de balie, zoals in de dagelijkse praktijk gebeurt, maakt bewaking nagenoeg onmogelijk.

Hoewel er naar aanleiding van een studie als deze geen stellige uitspraken mogelijk zijn, kan toch gewezen worden op de opvallende omvang van het verschijnsel balierecepten. Daarnaast mag worden aangenomen dat met name psycholeptica te waak worden voorgeschreven zonder dat de huisarts zelf is geconsulteerd. ${ }^{15-17}$ Het verdient aanbeveling om een uitgebreid onderzoek te verrichten bij een representatieve groep huisartsen waarin tevens die balierecepten betrokken zijn die nu buiten het onderzoek zijn gevallen.

\section{Dankbetuiging}

Voor de medewerking aan dit onderzoek gaat onze dank uit naar de huisartsen en de assistentes van de gezondheidscentra Hoensbroek in Hoensbroek, Van Kleef en Heer beide in Maastricht, en de praktijken Govaert-Ledlercq in Stein en Muyrers te Maastricht. 


\section{Luteratuur}

Andetson RM. The use of repeatedly prescribed medicines. J R Coll Gen Pract 1908; 30:609-13 Anonymus. City practice revealed repeat prescriptions. Update $1980 ; 20: 316-20$

Geddes G. Prescription writing by receptionists. Pham J 1976, 217: 186

Parker ESC, Schnieber V. Repeat prescribing atudy in one practice I R Coll Gen Pract 1980, 30:603-6 Tomblesen PMJ. Repesat prescriptions: was Balint right? Br Med J 1984; $289: 1506-8$

Crutckshank $\mathrm{CTT}$, Moix DC. A system for reconding and monitoring repeat prescriptions in a general practice. Health Bull 1979:37:180u4

Hamley JG, Browri SV, et all. Duplical 'prescriptions: an aid to research and review. J R Coll Gen Pract $1981 ; 31: 648-50$

Drury WWM. Repeat prescriptions. A review. I R Coll Gen PTact 1982; 32: 42.5

Ho-Yer R. A gtudy of repeat prescriptions cards in a general practice. J R Coll Ger Pract 1979; 29: 473-7

Conmisie structururschets informatievoorziening extramurale gezondheidszorg. Structururschets informatijevoorziming extramurale gezondheidszorg. 's Gravenhage: Nationale Raad voor de Volksgezondheid. 1986

1 Price D. Cooke J, Singleton S, Feely M. Doctors" unawareness of the drugs their patients are taking: a. major cause of owerprescribing? Br Med $J 1986 ; 292: 99-101$

Anonymus. Repentorium 85/86. Overzicht van furmaceutische specilités. Nefarma, 1985

Anonymous. International Classification of Primary Care. Manual as prepared by the WHO-Working Party on the ICPC. Geneva: World Health Organization, 1985

Tulloch AJ. repeat prescribing for elderly patients. Br Med 1981:282:1672-6

Anderson RO. The physician as an enabler of the chemically dependent patient. Postgraduate Med 1986 ; 79: $207-14$

6 Haggerty JI, et al. Psychotropic prescribing patterns of nonpsychiatric residents in a general hospital in 1973 and 1982. Hosp Comminity Psychiatry 1986, 4: 357

7 Freed A. Prescribing of tranquillisers and barbiturates by general practitioners. Br Med J 1976; ii: 1232 4 
hoofdstuk 3

\section{Langdurig gebruik van slaap- en kalmerings- middelen in een huisartspraktijk.}

Dit hoofdstuk is gepubliceerd als:

Vissers FHJA, Knottnerus JA, Van der Grinten RF, Van der Horst FGEM. Langdurig gebruik van slaap-en kalmeringsmiddelen in een huisartspraktijk. Huisarts Wet 1993, 36(12): 405-8 


\section{Abstract}

Objective. To investigate long-term use of hypnotic and tranquillizing drugs in general practice.

Setting. One general practice.

Method. Questionnaire among patients who were asking a repeat prescription for hypnotic or tranquillizing drugs.

Results. 118 patients who asked a repeat prescription for hypnotic or tranquillizing participated. Eighty percent of those 'repeats' were provided without a doctor-patient encounter. Health problems, with or without psychological problems, caused the complaints for which the psychofarmacon was used. Fourty eight percent of the users used the drug longer than one year. This group of long-term users showed almost no change in their complaints or problems causing these complaints. The pattern of use mostly did not change in the group of long-term users. The patients who were using the drug continuously (daily use) experienced their health to be less satisfactory than those who did not so (episodic use). They also talked more often with their general practitioner about reducing or stopping drug use and had more often a feeling that they could not stop without help of an expert.

Conclusion. Long-term users of hypnotic or tranquillizing drugs get their prescriptions mostly without a doctor-patient encounter. Patients who are using the drug continuously have a worse subjective health and cannot stop using without help.

Key words. family practice, repeat prescription, benzodiazepines. 


\subsection{Inleiding}

In Nederland wordt de huisarts vaak geconfronteerd met psychische en sociale problemen. ${ }^{1}$ Uit onderzoek blijkt dat bij één op de drie psychische klachten psychofarmaca worden voorgeschreven. ${ }^{2}$ Het wekt dan ook weinig verbazing dat deze middelen tot de meest voorgeschreven medicamenten in de huisartspraktijk behoren. ${ }^{1,3,4}$ Veel psychofarmaca (meestal slaap-en kalmeringsmiddelen) worden zonder arts-patiëntcontact via de doktersassistente (met name herhaalrecepten) aan de patiënt verstrekt. $3,5,6$

Er is onderzoek gedaan naar de klachten waarvoor psychofarmaca - veelal benzodiazepinen gebruikt worcien, maar nauwelijks naar de achterliggende oorzaak van de klachten. ${ }^{7-10}$ Uit. verschillende studies blijkt dat benzodiazepinen langdurig, vaak jaren acliter elkaar, gebruikt worden. 7,8,11-13 Tevens blijkt dat bij langdurig gebruik weinig animo bestaat om te stoppen met het middel; als er gestopt wordt, is het succespercentage bovendien laag. ${ }^{11,1417}$ Ook is niet duidelijk of de directe reden voor het gebruik (de klacht) dan wel de oorzaak van de klacht misschien verandert in de loop van de tijd. Als de klachten veranderd/verdwenen zijn, en eventueel ook de oorzaak ervan, heeft dat dan effect op het gebruik van het middel? Kan de patiënt dan wel stoppen, en in hoeverre is er sprake van tolerantie en afhankelijkheid of verslaving? $?^{18-21}$

De ervaring in eigen praktijk leert, dat langdurig gebruik van slaap- en kalmeringsmiddelen niet altijd gelijk staat aan dagelijks gebruik. Dit brengt de vraag met zich mee hoe groot het risico is, dat niet dagelijks gebruik overgaat in dagelijks gebruik. Hierover is ons geen huisartsgeneeskundige literatuur bekend.

Psychisch en psychosomatisch getinte problemen die aan de huisarts gepresenteerd worden, kunnen leiden tot het voorschrijven van slaap-en kalmeringsmiddelen. De huisarts staat vaak aan het begin van dit prescriptiebeleid. ${ }^{3}$ Het feit dat slaap-en kalmeringsmiddelen langdurig gebruikt worden en dat receptuur voor deze middelen veelal via de balie zonder arts-patièntcontact verstrekt wordt, kan ertoe leiden dat de huisarts minder zicht heeft op de indicatieste]Wing. Heeft de patiënt in de loop van de tijd een andere reden voor het gebruik van dieze middelen?

De hwisarts beeft een goed overzicht over de voorgeschreven receptuur en kan dus een bewakende en begeleidende rol vervullen. Hij kan dan ook grote invloed hebben op het ontstaan en de omvang van het (langdurig) gebruik van psychofarmaca. 
De vraagstelling van dit onderzoek luidt als volgt:

* Wat is in de ogen van de patient het patroon van oorspronkelijke klachten en achterliggende problemen, dat destijds aanleiding gaf tot het gebruik van het slaap- of kalmeringsiniddel?

* Is het gebruikspatroon veranderd in de loop van de tijd en is bij langdurig gebruik cen verandering te constateren in de oorspronkelijke klachten of de achterliggende problemen?

* Hoe is de satisfactie ten aanzien wan het gebruik van slaap- en kalmeringsmiddelen en in hoeverre denkt men erover te stoppen met het gebruik?

* Zijn er verschillen tussen continu en episodisch gebruikers van slaap- en kalmeringsmiddelen ten aanzien wan probleemoplossend gedrag, levensproblemen, gewoontevorming in koffie-, tabaks-en alcoholgebruik, eenzaamheid en gezondheidsbeleving? Is er verschil in hun houding ten aanzien van deze middelen?

\subsection{Methode}

In een gezondheidscentrum waarin drie artsen werkzaam zijn, werden gedurende zes weken alle patiènten die een herhaalrecept voor cen slaap- of kalmeringsmiddel kregen, uitgenodigd deel te nemen aan het onderzoek. Uitgesloten werden patiënten voor wie het onderzoek te belastend zou zijn of die niet in staat werden geacht de vragenlijst adequaat te beantwoorden (met name hoogbejaarden en niet-Nederlandstalige patiënten).

Indien de patiënt bereid was tot deelname, ontving hij een enquêteformulier met antwoordenvelop. Patiênten die de enquête na twee weken niet geretoumeerd hadden, werden telefonisch benaderd thet het werzoek de vragenlijst alsnog in te vullen en terug te sturen.

De enquête bestond uit vragen over achtergrondvariabelen, medicatiegebruik en de reden van het gebruik 
. Voorts werd gebruik gemaakt van de volgende onderzoekslijsten:

* De Groningse hijst voor langdurige moeilijkheden (GLLM). Hierop kunnen meer problemen tegelijk worden gescoord. De antwoordmogelijkheden zijn: nee, enigszins, nogal en jazeker; hiervan werden de laatstse twee als positief beschouwd. De bestaande vragenlijst is aangevuld met drie items: problemen met het verlies van een dierbaar persoon, problemen met verzorging van een chronisch ziek/invalide persoon thuis, en problemen met eigen gezondheid. ${ }^{22}$

* De eenzaamheidslijst. Dit is een lijst waarmee sociale steun gemeten wordt. ${ }^{23}$

* De verkorte versie van de Hopkins-lijst (HSCL), die ervaren gezondheid meet. ${ }^{24}$

* De Utrechtse Coping-Lijst. ${ }^{25}$

* De lijst van Wallace voor alcoholverslaving. ${ }^{26}$

De onderzoekspopulatie werd onderverdeeld in langdurig (>ljaar) en kortdurend ( $\leq$ ljaar) gebruikers. Bij de langdurig gebruikers werd bovendien onderscheid gemaakt tussen continu en episodisch gebruikers.

De gegevens werden statistisch bewerkt met behulp van BMDP statistical software. In voorkomende gevallen werd statistisch getoetst door middel wan de Pearson chi-kwadraattoets voor onafhankleijke proporties en de Mann-Witney toets in geval van numerieke waarnemingen.

\subsection{Resultaten}

Ten tijde van het onderzoek waren in het gezondheidscentrum 4600 patiënten ingeschreven. In totaal 163 patiënten vroegen (en kregen) een herhaalrecept voor een slaap- of kalmeringsmiddel. Van deze patiënten werden er 45 uitgesloten; 7 patiënten weigerden deel te nemen en 21 stuurden de enquête niet terug. De definitieve onderzoekspopulatie bestond dus uit 90 personen, 32 mannen en 58 vrouwen, van wie 5 mannen en 17 vrouwen alleenstaand.

Op de vraag hoe het recept meestal herhaald werd, antwoordde 77 procent dat dit via de balie gebeurde. Er was hierin geen verschil tussen beide geslachten. De huisarts was in 78 procent van de gevallen de eerste voorschrijver (zelf of via de assistente).

Het meest voorgeschreven middel was oxazepam (Seresta), daama kwam bromazepam (Lexotanil) (rabel $I$ ).

Het middel waarvoor een herhaalrecept werd gevraagd, was in 30 procent van de gevallen voorafgegaan door een ander psychofarmacon; in slechts 4 procent van de gevallen had de patiënt zelf eender een middel gekocht 
tabel 1. Bij 90 patiènten zonder arts-patient contact woorgeschrever slaap- of kalmeringsmiddelen. Aantallen.

\begin{tabular}{|c|c|}
\hline Oxazeparm (Steresta) & 26 \\
\hline Bromazepam (Lexolanil) & 17 \\
\hline Temazepam (Nonnison) & 9 \\
\hline Diazeparm (Valum) & 8 \\
\hline Lometazeparn (Noctamid) & 7 \\
\hline Flurazepam (Dalmadorm) & 5 \\
\hline Nitrazepam (Mogadon) & 4 \\
\hline Funitrazepam (Rohypnol) & 4 \\
\hline Chlcordiazepoxyde (Librium) & 2 \\
\hline Midazolan (Dormicum) & 2 \\
\hline Overige & 6 \\
\hline
\end{tabular}

\section{Oorspronkelijke klacht en achterliggende problemer.}

De open vraag naar de klacht warvoor de huidige medicatie werd gebruikt, werd door 39 respondenten beantwoord met 'slaapstoornissen'; 'nervositeit' werd 30 maal genoemd.

Als oorzaak van de klacht werden problemen met eigen gezondheid, all dan niet in combinatie met een ander probleem, het meest genoemd $(35 \mathrm{x})$. Daarna volgden problemen met verlies van een dierbaar persoon (15x), problemen op het werk (14x), problemen met kinderen (14x), met partner $(9 x)$, met financiën $(8 x)$, en met ouders $(8 x)$. Voor beide geslachten was hierin geen verschil.

In totaal 23 patiënten noemden geen duidelijke oorzaak voor de klachten waarvoor een slaapof kalmeringsmiddel gebruikt werd. Van de 39 patiënten die alleen slaapproblemen hadden opgegeven, konder er 32 een of meer oorzaken voor deze klacht noemen. Van de 35 patiënten die problemen met eigen gezondheid als corkakk van het gebruik van psychofarmaca hadden genoemd noemden 11 deze oorzaak als enige.

\section{Veranderingen in gebruikspatroon.}

Bij 76 patiẻnten was er sprake van llangdurig gebruik; 18 patiènten gebruikten het gevraagde middel al langer dan 10 jaar en 43 langer dan 5 jaar; 14 patiénten waren in het voorafgaande jaar begonnen met het gebruik van een slaap- of kalmeringsmiddel. De klacht waarvoor het psychofarmacon het eerst was gebruikt, was in 82 procent van de gevallen dezelfde als de huidige klacht, terwijl de oorzaak van de klacht in 80 procent van de gevallen dezelfde was.

Op de vraag hoe het slaap- of kalmeringsmiddel het laatste jaar gebruikt was, antwoordden 51 patiënten het middel voortdurend te gebrüken; 13 patiënten gebruilkten het gedurende één 
periode en 23 gedurende verscheidene perioden; 2 patiëtren hadden het in het afgelopen jaar niet gebruikt, en 1 patiènt had deze vraag niet beantwoord.

Voor 72 langdurige gebruikers werd het huidige gebruik vergeleken met her gebruik in de beginperiode. Van de 49 dagelijks gebruikers bleken 44 patiẻnten het middel destijds ook al dagelijks te gebruiken. Van de 23 episodisch gebruikers gebruikten 13 destijds het middel ook al episodisch. In totaal bleek het actuele gebruikspatroon in 79 procent van de gevallen al in de beginperiode aanwezig (tabel $2, p<0,001$ ).

tabel 2. Gebruikspatroon bij langdurig gebruikers van slaap-of kaimeringsmiddelen gedurende hat afgelopen jaar. vergeleken met het gebruikspatroon bij het begin van het gebruik. Aantallen.

\begin{tabular}{lccc} 
& \multicolumn{3}{c}{ Gebnuik in afgelopen jair } \\
\cline { 2 - 4 } gebruik bij de start & continu* & episodisch ${ }^{* *}$ & total \\
\hline \hline continu* & 44 & 10 & 54 \\
episodisch** & 5 & 13 & 18 \\
totaal & 49 & 23 & 72 \\
\hline
\end{tabular}

* continu gebruik: dagelijks en voortdurend

*** episodisch gebruik: a) minstens $1 . x /$ wk, maar niet dagelijks b) minstens $1 \times / m n d$, maar niet wekelijks c) anders

\section{Satisfactie en wens tot stoppen.}

De overgrote meerderheid $(n=82)$ van de patienten was tevreden over de werking van het medicament. Ontevredenheid bleek met name te berusten op geen of te weinig effect van het middel; op bijwerkingen werd niet gescoord. Schuldgevoel (heel vaak/vatak/soms) over het gebruik was er bij 35 patiènten; 40 patiènten hadden het afgelopen jaar (heel vaak/vaak/soms) het gevoel gehad te moeten minderen of stoppen met het gebruik. In totaal 38 patiènten brachten dit ter sprake bij respectievelijk de huisarts (20), de specialist (6) of iemand anders zoals partner of familielid (12). Zelfstandig stoppen met het gebruik van thet slatp- of kalmeringsmiddel werd door 53 patiènten niet mogelijk geacht; de hulpverlener die bet beste zou kunnen helpen met stoppen was volgens hen de huisarts $(29 x)$, de specialist $(12 x)$, de maatschappelijk werker $(7 x)$, de psycholoog $(3 x)$ of iemand anders $(2 x)$. 
Verschillen tussen continu en episodisch gebruikers.

Tussen de groep continu $(n=46)$ en de groep episodisch $(n=41)$ gebruikers werden slechts enkele verschillen gevonden:

- geen verschillen in geslacht, burgerlijke staat en woonsituatie;

- geen verschillen in gebruik van koffie, tabak en alcohol;

- geen verschillen in problemen waarvoor een slaap- of kalmeringsmiddel werd gebruikt, met uitzondering van de financiële problemen, die in de groep episodisch gebruikers vaker werd genoemd;

- enig verschil in irritatiegevoelens door opmerkingen van anderen over het gebrük (14 versus $5 ; \mathrm{p}=0,08)$;

- geen verschil in schuldgevoel over het gebruik;

- wel verschil in het bespreken met een hulpverlener van het minderen/stoppen van de medicatie $(27$ versus $11 ; p=0,002)$; werder zouden 36 continu gebruikers niet zonder deskundige hulp kunnen stoppen tegen 16 episodisch gebruikers $(p=0,001)$;

- geen verschil in eenzaambeid en geen verschil op de psychische schaal van de Hopkinslijst:

- wel verschil in de gemiddelde score op de somatische schaal van de Hopkins-lijst (continu gebruikers gemiddeld 8,2 en episodisch gebruikers 6,$1 ; p=0,04$ ) en ook verschil in de gemiddelde totaalscore van de Hopkins-lijst (continu gebruikers 25,3 en episodisch gebruikers 19,$1 ; \mathrm{p}=0,05)$;

- een klein verschil in gemiddelde scores op de depressieschaal van de coping-lijst (continu gebruikers 14,9 en episodisch gebruikers 13,$3 ; p=0,09$ ); geen verschil in de overige zes dimensies;

- geen verschil in de score op de Wallace-lijst voor alcoholverslaving.

\subsection{Beschowwing}

Zeker bij langdurig gebruik van slaap-en kalmeringsmiddelen is het de patiënt die de indicatie voor het gebruik bepaall. Bovendien vermeldt de registratie van de huisarts vooral klachten en ziektebeelden en slechts zelden de achterliggende oorzaak. Daarom is in dit onderzoek bewust gekozen voor de mening van de patiẻnt als invalshoek. Dit brengt het risico van recall bias met zich mee. De registratiegegevens van de huisarts zijn voor een dergelijk onderzoek echter ook niet zonder meer betrouwbaar. 
De onderzoekspopulatie was klein en de gegevens van de subpopulaties moeten met terughoudendheid geinterpreteerd worden. Herhaalrecepten voor slaap- en kalmeringsmiddelen bleken in 80 procent van de gevallen via de balie verstrekt te zijn. Vrouwen waren in de onderzoekspopulatie in de meerderheid. Slapeloosheid was de meest genoemde klacht waarvoor deze middelen gebruikt werden. Gezondheidsproblemen, al dan niet in combinatie met psychosociale problemen, werden door de patiënten het meest als oorzaak van de klachten beschouwd. Bijna cen derde van deze subgroep vermeldde daarbij geen andere (psychosociale) problemen. Klachten en achterliggende problemen bleken in de tijd dat een slaap- of kalmeringsmiddel gebruikt werd nauwelijks te veranderen. Hetzelfde gold voor het gebruikspatroon.

Voor het idee dat episodisch gebruik veelal over zou gaan in continu gebruik, kon geen steun gevonden worden. Continu gebruikers badden meer somatische problemen en toonden in hun coping een tendens naar depressief gedrag; het stoppen met het slaap- of kalmeringsmiddel zonder deskundige hulp werd door hen frequenter als een probleem aangegeven, en ze hadden het gebruik van deze middelen vaker met een hulpverlener besproken.

De vraag dient gesteld te worden in hoeverre de huisarts langdurig gebruik van slaap-en kalmeringsmiddelen kan voorkomen. In dit kader zijn de volgende overwegingen van belang:

* Extra voorzichtigheid is geboden bij patiënten die tekenen van een mogelijke depressie vertonen.

* Vrouwen lijken meer kans te hebben om chronisch gebruiker te worden; dit ligt mogelijk in de aard van de achterliggende problematiek, het hulpvraaggedrag of de interactie tussen huisarts en patiënte.

* Gezondheidsproblemen blijken in de perceptie wan de patiènt relatief vaak de oorzaak te zijn van klachten waarvoor een slaap- of kalmeringsmiddel gebruikt wordt. ${ }^{27}$ De meest genoemde reden voor het gebruik van slaap- of kalmeringsmiddelen was slapeloosheid. Het is dus de moeite waard bij slaapproblemen eerst na te gaan of er somatische problew men zijn en te proberen deze op te lossen. ${ }^{2}$

* Wanneer een ander slaap- of kalmeringsmiddel dan tevoren wordt voorgeschreven, kan verlenging van het voorschrift beter niet via de balie plaatsvinden. Op die manier wordt het de potentiële continu gebruikers met vermijdingsgedrag niet nodeloos gemakkelijk gemaakt.

Om ons inzicht te vergroten is verder onderzoek in een grotere populatie en met eern controlegroep van niet-gebnuikers gewenst; daarbij dient de informatie van de voorschrijvend huisarts ook betrokken te worden. Het doel moet zijn de huisarts een leidraad te geven om op verant- 
woorde wijze slalap-en kalmeringsmiddelen voor te schrijven en het gebruik verantwoord te bewaken, om zodoende langdurig gebruik war mogelijk te woorkomen. Het is voor de huisarts practicus belangrijk dat hij op de hoogte gebracht wordt van risicofactoren voor continu gebruik van deze middelen, zodat hij daarmee rekening kan houden bij de (eerste) prescriptie daarvan.

\section{Dankbetuiging}

Met dank aan de doktersassistentes ML. de Bruyn-Hoppener, M. Frijns, C. Gündlach † en de collegae A. Muyskendu Saar en M. Peeters wan het gezondheidscentum Heer, voor hun medewering aan het onderzoek. Tevens is dank verschuldigd aan mw. T. Seegers voor de bewerking van de onderzoeksgegevens. 


\section{Literatuur}

1 Lamberts $H$, Harman B. Psychische en sociale problemen in de huisartspraktijk. Huisarts Wet 1982 ; 25 : $333-42,376-88$.

2 Jol A, Verhaak P. Psychische en sociale klachten: geprekswoering of psychofarmaca. Huisarts Wet 1989 ; $32: 89-95$.

3 Plagge HWM, Vissers FHJA, Pouls $\mathbb{K}$, De Geus $C A$. Het voorschrijven van geneestmiddelen zonder artspatiënt contact in de huisartspraktijk. Huisants Wet 1988; $31: 120-3$.

4 Muusse-Serewel AM, Willems JHBM, De Kort WLAM. Geneesmiddelengetmik onder de Nederlandse beroepsbevolking. Med Contact 1990; 45:677-9.

5 Anderson $R$. The use of repeatedly prescribed medicines. I R Coll Gen Pract 1980; 30: 609-13.

6 Freeman R. A study of telephone prescriptions in family practice. J Fam Pract 1980; 10:857-62.

7 Catalan I, Gath DH, Bond A, et al. General practice patients on longterm psychotropic drugs. Br I Psychiatry 1988: 152: 399.405.

8. Rodrigo EK, King MB, Williams P. Health of long-term benzodiazepine users. Bri Med J 1988; 296: 6036.

9 Bogaerds G. Slaap en slaapstoomissen. Mod Med 1990; 407-9

10 Post D. De plaats van de benzodiazepines in het farmacotherapeutisch arsenaal. Practitioner NI 1990; 15 : 1025.33.

11. Salinsky JV, Dore CJ. Characteristics of long-term benzodiazepine users in general practice. J R Coll Gen Pract $1987 ; 37: 202-4$.

12 Mant A, Duncam-Iones P, Salman D, et al. Development of long-term use of psychotropic drugs by general practice patients. Br Med J 1988; 296; 2514.

13 Morgan K, Dallosso H, Ebrahim S, et al. Prevalence, frequency and duration of hypnotic drug hase among the elderly living at home. Br Med J 1988; 296: 601-2.

14 King MB, Gabe J, Williams P, Rodrigo EK Long-term use of benzodiazepines: the view of patients. Br J Gen Pract 1990: $40: 194-6$.

15 Matalon A, Yinnon AM. Hurwitz A. Chronic use of hypnotics in a family practicempatients' reluctance to stop treatment. Fam Pract $1990 ; 7: 258-60$.

16 Haarselhorst $M$, Wester F. Vrouwen, benzodiazepinegebruik en zelfhulp. Tijdschr Soc Gezondheidszorg $1992 ; 2 ; 118 \cdot 22$

17 Eijkelenboom $P_{\text {n }}$ Springer M, Dekker F. Het Leidse slaapprotocol. Huisarts Wet 1992; 35; $465-9$.

18 Van der Laan L. Afhankelijkheid van benzodiazepinen; omvang risico's en eventuele verschillen tussen de middelen onderling. Ned Tijdschr Geneeskd 1984; 128: 809-14.

19 Offerhaus L. Nogmaals benzodiazepinen: te veel, te lang en te sterk? Ned Tijdscht Gemeeskd 1988; 132 : $1921-4$.

20 Zitman F. Verslaving aan geneesmiddelen. Patient Care 1989; Dec: $43-9$.

21 Kamphuisen H. Slecht slapen door slaapmiddelen. (rebound insorana), en de plaats van zoplicon. Ned THidschir Geneeskd 1992: 136: 556-8.

22 Anoniem. GLLM ${ }_{n}$ Groningse Lijst Langdurige Moeilijkheden. In: Ormel J. Met Groningse eerstelijnsprojekt: opzet en aanpak [intem rapport]. Groningen: Rjksumi wersiteit Groningen, afdeling sociale psychiatrie. 1985.

23 De Jongh-Gierveld I, Kamphuis $F$. The development of a Rash-type loneliness scale. Applied Psychologi. cal Measurement $1985 ; 9: 289-99$.

24 Anoniem. HSCL, Hopkins Symptom Checklist. In Luteyn $F$, Hamel L, Bouwman $T$, Kok A. ISCL. Lisse: Swets en Zeillinger, 1984.

25 Schreurs $P$, Van de Willige $G$, Tellegen $B$, Brosschor J. UCL, Utrechtse Coping Lijst. Omgaaly mut problemen en gebeurtenissen. Handlieiding. Vakgroep klinische psychollogie, Rijksuniwersiteit Utrecht, 1993.

26 Wallace $\mathbb{P}$, Haines $A$. Use of a questionnaire in general practice to increase recognition of patients with excessive alcohol consumption. Br Med I 1985;290: 1949-53.

27 Simpson $\mathbb{R}$, Power KG, Wallace $\mathrm{LA}$, et al. Controlled comparison of the characteristics of long term benzodiazepine users in general practice. Br J Gen Pract 1990; 40:22-6

28. Knulistingh Neven A, De Graaff W], Lucassen PLBJ, et al. NHG-standaard Slapelonsheid en Slaapmiddelen. Hudisarts We: $1992 ; 35: 212-9$. 
34 
hoofdstuk 4

Benzodiazepinen.Karakteristieken van gebruik en gebruikers. Een systematische analyse van literatuur betreffende eerstelijns-onderzoek. 


\section{Abstract}

Objective. To describe characteristics of long-term use of hypnotic and tranquillizing drugs.

Method. Literature search. In this search we looked for studies in general practice concerning patterns of use, indication for use and characteristics of users.

Results. Several descriptions of use were found. The definition of long-term use is essentially different in several studies. Being a woman, having a high age and a low education were associated with long-term use. Long-term users have more health and psychological problems, and use more concomitant drugs. There is no relation between using hypnotic or tranquillizing drugs and use of alcohol, coffee or tobacco.

Conclusions. There is no common definition of the various types of use of hypnotic and tranquillizing drugs. The use of a general classification of patterns of use is recommended. Key words. hypnotic drugs, tranquillizing drugs, benzodiazepines, characteristics, use 


\subsection{Inleiding}

In de zestiger jaren werd chloordiazepoxyde (een benzodiazepineverbinding) op de markt gebracht en verdrong meprobamaat: het zou een betere werking hebben en minder bijwerkingen. In de loop van de jaren zijn verschillende benziodiazepinen geproduceerd; thans is een twintigtal benzodiazepinen (en beduidend meer specialités) op de markt. ${ }^{\prime}$

De mate van benzodiazepine-gebruik is niet in alle landen hetzelfde. In een in 1981 uitgevoerd onderzoek naar het gebruik van kalmeringsmiddelen in de Verenigde Staten en tien West Europese landen bleek de prevalentie van gebruik in de diverse landen te variëren van $7.4 \%$ tot $17.6 \%$. Nederland scoorde met $7.4 \%$ het laagst. De prevalentie van langdurig (dat wil zeggen langer dan 12 maanden), dagelijks gebruik van kalmeringsmiddelen varieerde van $0.5 \%$ in Zweden tot $5.8 \%$ in Belgie. In Nederland was dit $1.7 \%{ }^{2}$ Uit gegevens van een national onderzoek in Nederland in 1987 uitgevoerd bleek de prevalentie van benzodiazepineprescriptie voor de vrouwen $9 \%$ en voor de mannen $4.6 \%$ te zijn. ${ }^{3}$

Onderzoek in Engelse huisartspraktijken in 1980 toonde aan dat, na cardiovasculaire medicijnen, psychofarmaca het meest voorgeschreven werden. ${ }^{4}$ Uit recentere Nederlandse studies blijkt dat ze in ons land op de derde plaats staan na cardiovasculaire middelen en analgeti$\mathrm{ca}^{5,6} \mathrm{Bij}$ de baliereceptuur -veelal herhaalrecepten afgegeven zonder arts-patiënt contactbleken de slaap- en kalmeringsmiddelen, na medicamenten voor de tractus respiratorius, de tweede plaats in te nemen. ${ }^{7}$ In de nationale geneesmiddelenomzet (389 miljoen gulden in 1992) staan de middelen voor het centraal zenuwstelsel op een derde plaats na die voor de uractus digestivus en tractus circulatorius. ${ }^{8}$

Benzodiazepinen verschillen onderling zowel farmacokinetisch als in hur slaapbevorderend, anxiolytisch, dempend/sederend, spierrelaxerend, anticonvulsief effect." Het zijn in het algemeen veilige middelen, maar intoxicatie zelfs met fatale afloop is mogelijk. ${ }^{910}$ Naast de gewenste effecten zijn er ook ongewenste bijwerkingen zoals sufheid, vermoeidheid, geheugenverlies, coördinatiestoornissen, hang over, angstreductie met onverantwoord gedrag bijvoorbeeld in het verkeer, valaccidenten en paradoxale reacties zoals agitatie en agressie. 11.17 Aan langdurig gebruik kleven nadelen zoals tolerantie en afhankelijkheid en dientengevolge abstinentieverschijnselen. $13,15,18,19$

Voorschrijvers van benzodiazepinen dienen zich bewust te zijn wan deze voor de patiént nadelige neveneffecten. Voor een verantwoord prescriptiebeleid is het van belang inzicht te hebben in de wijze waarop patiënten omgaan met de voorschriften, hoe het beloop van het gebruik is, wat de aanleiding ertoe vormt en welke patientkenmerken het beloop bejinvloeden. 
In deze literatuurstudie wordt daarom een overzicht gegeven van tot nu toe onderzochte factoren:

1) Wijze van gebruik

Hoe gaat de patiênt om met het oorspronkelijk voorschrift wan de arts? Gaat hij meer/minder gebruiken, stopt hij, hervat hij het gebruik? Is er een verloop te bespeuren van af en toe gebruiken naar langdurig en dagelijks gebruik? Is er na verloop van tijd sprake van misbruik, dat wil zeggen te veel of te langdurig?

2) Indicatiestelling

Waarom wordt het middel gebruikt, welke klacht(en) heeft de patiènt? Heeft hij bij langdurig gebruik steeds dezelfde of andere klachten? Is de oorzaak van deze klacht(en) steeds dezelfde, of zijn er in de loop van de tijd steeds weer nieuwe problemen waardoor de klacht weer opflakkert?

3) Kenmerken van de gebruiker

Hebben geslacht of leeftijd invloed op het wel of niet langdurig gaan gebruiken? Welke invloed hebben factoren als sociaal-economische status, ethnische afkomst, gewoontexorming, psychische gesteldheid en gezondheid hierop?

\subsection{Methode}

In Medline werden publicaties geselecteerd van 1962 tot 1995 . Een selectie werd gemaakt op het steekwoorden benzodiazepine en/of general practice/eerstelijn; deze selectie werd telkens gekoppeld aan volgende steekwoorden: prescription, drugs, tranquillizers, hypnotics, sedatives, abuse, long-term, short-term, intoxication/poisoning, dependence, reduction/discontinue/stop, insomnia , depression, anxiety, profile user. Tevens werden de referentielijsten van de artikelen gebruikt om andere relevante publicaties op te sporen. Artikelen werden via de universiteitsbibliotheek in Maastricht verkregen

Onze interesse ging vooral uit naar literatuur betreffende bevolkings- of eerstelijns onderzoek, bij voorkeur met een controlegroep van niet-gebruikers. In de resultaten dienden wijze van gebruik, indicatiestelling en kenmerken van de gebruiker besproken te zijn en onderzochte medicamenten omschreven. 


\subsection{Resultaten}

\section{Algemeen}

De zoektocht naar karakteristieken van benzodiazepinegebruik en -gebruikers leverde een zeventigtal artikelen op. Er werden in totaal 15 eerstelijnsstudies en bevolkingsonderzoeken .

tabel 1. Overzicht van de in de literanur aangetroffen begrippen (Engelstalig cursief) ten amzien wam de wiyze van gebruik van slaap* en kalneringsmiddelen, met betrekking tot de tijd-as wan her gebruik.

\section{WTZE VAN GEBRUIK}

cenmalig, gelegenheids gebruik occasional use

langdurig gebruik
long-term use

\section{OMSCHRIIVING}

enkele dagen to 11 maanden 21

een episode (een of enkelle dagen/weken/manden aaneengestoten zonder herhaalwoorschuift) 20

dagelijks en langer dan 12 maanden

minimaal 1 recept/3maanden gedurende 1 jaar 23

mimstens 3 herhaalrecepten $/ 3$ matanden 2

1 of meer herhaalrecepten over een periode van 1 jwar 26

herhaalrecepten over een periode van 1 jaar 2

gebruik langer dan 6 maanden 2

episodisch of chronisch gebruik langer dan 1 jaar 20

minimaal 1 recept/2maanden en langer dan 6 maanden 28

\begin{tabular}{ll}
\hline $\begin{array}{l}\text { chronisch gebruik. } \\
\text { chronic use }\end{array}$ & 4 of meer recepten in 6 maanden \\
& dagelijks en voortdurend \\
& minstens 4 dagen/week en langer dan 6 maanden 30 \\
& minstens 3 dagen/week en langer dan 6 maanden 31 \\
\hline
\end{tabular}

reggellinatig gelonuik

regular use

gebruik tanger dan 1 jaar, minimaal epidodes wan (bijna) dagelijks gedurende minstens 2 maanden 36

dagelijks tot bujna dagelijks 33

dagelijks of niet dagelijks en 2 of meer recepten per jaar 5

\begin{tabular}{|c|c|}
\hline continu gebnuik & dagelijks en blijvend 20 \\
\hline episodisch gebruik & $\begin{array}{l}\text { een of enkele dagew/weken/maanden aaneengesloten, wastbij het voor- } \\
\text { schrift cen of mear ker herthald is } 20\end{array}$ \\
\hline $\begin{array}{l}\text { kortdurend gebruik } \\
\text { short-term use }\end{array}$ & $\begin{array}{l}\text { gebruik korter dan } 1 \text { maand } \\
20 \\
\text { gebruk korter dan } 1 \text { jaar }\end{array}$ \\
\hline intermediate use & gebrulk 1 tot 3 maanden ${ }^{2}$ \\
\hline
\end{tabular}


gevonden, die met een controlegroep uitgevoerd waren. Deze werden in de analyse van karaktenistieken van gebruikers opgenomen. Alleen statistisch significante bevindingen zullen worden besproken, tenzij anders vermeld

\section{Wize van gebruik}

Een overzicht van de in de literatuur gebezigde begrippen ten aanzien van de wijze van ge bruik, met betrekking tot de tijd-as van het gebruik, wordt gegeven in tabel 1. De gehanteerde criteria voor langdurig gebruik variëren van 3 maanden tot langer dan 12 malanden. De mate van gebruik, variêrend van dagelijks, regelmatig tot episodisch, wordr veelal gemeten aan de hand van het aantal verstrekte recepten in de loop van een bepaalde tijdspanne. 'Regular use' is als een vorm van langdurig gebruik te beschouwen, waarbij niet continu gebruikt wordt. Naast kortcurend gebruik vinden we termen als gelegenheidsgebruik (occasional") en eenmalig gebruilk.

De duur van eenmalig gebruik varieert van enkele dagen tot 11 maanden. ${ }^{20-31}$ Langdurig gebruik varieert qua duur van gebruik in de verschillende onderzoeken gemiddeld van 3 tot 10 jaar, met een maximum van 23 jaar. $23,32,40,42$

tabel 2. Overige karakteristieken wan de wijze van gebruik van slaap- en kalmeringsmiddelen vermeld in de (Engelstalige) literatuur.

\section{KARAKTERISTIEKEN van GEBRUIKER} day-time wser 32

panil user hoarder cutrent uiser oarrigifi" dosis escalator 33,34

\section{OMSCHRIJVTNG}

gebruik overdag gebruil 's nachts

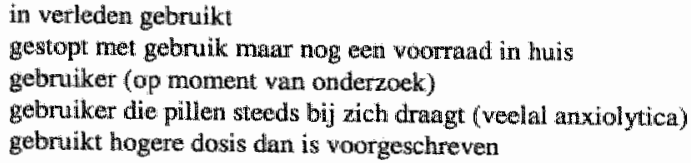

Aan de wijze van gebruik kunnen nog andere karakteristieken toegekend worden, waarbij het moment van innemen ook een rol speelt (tabel 2). Hierbij wordt opgemerkt dat anxiolytica veelal overdag worden gebruikt en hypnotica "s nachts. ${ }^{32}$ In 1994 werden naast begrippen als day-time en night-time user, de begrippen medical en polydrug user ingevoerd. ${ }^{35}$ 
tabel 3. Overzicht van populatiesurveys en eerstelijnsstudies natar gebuik van slaap-en kalmeringsnaiddelen, vitgevoerd met controiegroep/niet-gebruikers.

\begin{tabular}{|c|c|c|c|c|c|c|}
\hline $\begin{array}{l}\text { jaartal le auteur } \\
\text { land }\end{array}$ & $\begin{array}{l}\text { plats van onderzokek } \\
\text { selectie onderzpopulatie } \\
\text { methode varn onderzoek }\end{array}$ & aental & $\begin{array}{l}\text { leeftijd } \\
\text { selectie }\end{array}$ & middel* & $\begin{array}{l}\text { aard } \\
\text { van } \\
\text { gebtruik }\end{array}$ & $\begin{array}{l}\text { aantal } \\
\text { gebruikers } \\
\text { (n) }\end{array}$ \\
\hline 1978 Mellinger 36 & bevolkingsonderzoek & & 18.74 & ATR & & 1378 \\
\hline U.S. & $\begin{array}{l}\text { steekproef } \\
\text { interview }\end{array}$ & 2552 & & $\begin{array}{l}\text { SED } \\
\mathrm{AD}\end{array}$ & regelmatig & 484 \\
\hline 1978 Uhlentuth ${ }^{37}$ & bevolkingsonderzoek & & $18-64$ & MTR & alle & 147 \\
\hline 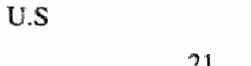 & $\begin{array}{l}\text { steekproef } \\
\text { interview }\end{array}$ & 735 & & SED & & \\
\hline $\begin{array}{l}1984 \text { Mellinger }^{21} \\
\text { U.S. }\end{array}$ & $\begin{array}{l}\text { bevolkingsonderzoek } \\
\text { steekproef }\end{array}$ & 3161 & $18-79$ & $\mathrm{AL}$ & alle & 347 \\
\hline 1985 Wells $^{39}$ & $\begin{array}{l}\text { Intervew } \\
\text { bewolkingsonderzoek }\end{array}$ & & 218 & ATR & alle & 526 \\
\hline U.S. & $\begin{array}{l}\text { steekproef } \\
\text { enquête }\end{array}$ & 4007 & & $\begin{array}{l}\text { SED } \\
\text { HY }\end{array}$ & & \\
\hline $\begin{array}{l}1986 \text { Blijenberg } \\
\text { Nederland }\end{array}$ & $\begin{array}{l}\text { bevolkingsonderzoek } \\
\text { steekproef }\end{array}$ & 2150 & $16-69$ & SLK & dagelijks & 144 \\
\hline $\begin{array}{l}1987 \text { Salinsky }^{32} \\
\text { U.K. }\end{array}$ & $\begin{array}{l}\text { interview } \\
1 \text { huisartspraktijk } \\
\text { monitoring prescriptie }\end{array}$ & 6000 & - & $\mathrm{BD}^{\wedge}$ & $>1$ jaar & 96 \\
\hline $\begin{array}{l}1988 \text { Dunbar }^{34} \\
\text { U.K. }\end{array}$ & $\begin{array}{l}\text { enquête } \\
\text { bevolkingsonderzoek } \\
\text { steekproef } \\
\text { interview }\end{array}$ & 1284 & $\geq 16$ & $\mathrm{BD}$ & alle & 311 \\
\hline $\begin{array}{l}1988 \text { Catalan }^{23} \\
\text { U.K. }\end{array}$ & $\begin{array}{l}11 \text { huisartspralktijk } \\
\text { monitoring prescriptie } \\
\text { interview }\end{array}$ & 8842 & - & PTR & $>1$ jaar & $\begin{array}{l}318 \\
\text { random } \\
205\end{array}$ \\
\hline $\begin{array}{l}1988 \text { Gene-Badia } \\
\text { Spanje }\end{array}$ & $\begin{array}{l}\text { le-lijnscentrum } \\
\text { monitoring presciptie } \\
\text { interview }\end{array}$ & 4700 & -- & BD & alle & 107 \\
\hline $\begin{array}{l}1989 \text { Dunbar }^{33} \\
\text { U.K. }\end{array}$ & bevolkingsonderzoek & 41.48 & $\geq 16$ & $\mathrm{BD}^{\wedge \mathrm{A}}$ & alle & 318 \\
\hline $\begin{array}{l}1989 \text { Ashton } 41 \\
\text { U.K. }\end{array}$ & $\begin{array}{l}\text { interview } \\
\text { bewolkingsonderzoek } \\
\text { stcekproef } \\
\text { interview }\end{array}$ & 9003 & $\geq 18$ & $\begin{array}{l}\text { TR } \\
\mathrm{HY}\end{array}$ & $\begin{array}{l}\text { alle } \\
\text { actuele } \\
\text { gebruik }\end{array}$ & 296 \\
\hline $\begin{array}{l}1990 \text { Simpson }^{42} \\
\text { U.K. }\end{array}$ & $\begin{array}{l}\text { 3. huisartspraktijken } \\
\text { monitoring prescriptie } \\
\text { dossieranalyse }\end{array}$ & 17000 & $-\infty$ & $\mathrm{BD}$ & $\begin{array}{l}>3 \text { herhaal } \\
\text { recepten }\end{array}$ & $\begin{array}{l}445 \\
\text { random } \\
206\end{array}$ \\
\hline $\begin{array}{l}\text { 1993Lagro-Janssen } \\
\text { Nederland }\end{array}$ & $\begin{array}{l}\text { duo-huisartspraktijk } \\
\text { monitoring prescriptie } \\
\text { interview/registratie }\end{array}$ & w & $\cdots$ & $\mathrm{BD}$ & $\begin{array}{l}>2 \text { recept } \\
\text { per jaar }\end{array}$ & 99 \\
\hline $\begin{array}{l}1993 \text { Waals }^{6} \\
\text { Nederland }\end{array}$ & $\begin{array}{l}45 \text { huisartspraktijken } \\
\text { monitoring prescriptie }\end{array}$ & 61249 & $\ldots$ & $\mathrm{BD}$ & & 4231 \\
\hline $\begin{array}{l}1995 \mathrm{Mant} \\
\text { Australled }\end{array}$ & $\begin{array}{l}\text { consultregistratie } \\
286 \text { huisartspraktijken } \\
\text { monitoring prescriptie } \\
\text { consultregistratie }\end{array}$ & 31256 & $\geq 15$ & $\begin{array}{l}\mathrm{BD} \\
\mathrm{AD} \\
\mathrm{AP}\end{array}$ & alle & 2075 \\
\hline
\end{tabular}

* onderzochte psychofamaca: ATR: alle tranquillizers SED: sedativa AD; antidepressiva MTR: minor tranquillizers $\mathrm{BD}$ : benzodiazepinen $\mathrm{BD}^{\wedge}$ : benzodiazepinen excl. hypnotica $\mathrm{BD}^{\mathrm{A}}$ : 10 meest gebruikte benzodiazepinen in woorgaand jaar AL: anxiolytica HY: hypnotica SLK: slatp eni kalmeringsmiddelen PTR: alle psychotropica AP: 
Het op eigen initiatief verhogen van de voorgeschreven dosis is slechts in ến studie onderzocht. Van alle soorten gebruikers in die studie behoorde $11 \%$ tot de zogenamale dosage escalators. Bij $22 \%$ werd de dosis met goedkeuring van de arts veranderd. ${ }^{33}$

Resumerend kan men stellen dat de volgende omschrijvingen gevonden zijn: de wijze van gebruik kan eenmalig of één episode zijn of niet. Het niet-eenmalig gebruik kan kort- of langdurend zijn, waarbij het middel episodisch, regelmatig of continu gebruikt kan worden.

Voorts kan men onderscheiden: day- en night-time user, hoarder, carrier, dosage escalator en medical en polydrug user (tabel 2 ).

\section{Indicatiestelling}

Van de onderzochte studies met controlegroep (tabel 3), waarin alleen slaap en kalmeringsmiddelen onderzocht werden, hebben slechts vier studies de prescriptie-indicatie nader beschreven. Uhlenhuth concludeert uit zijn onderzoek dat gebruikers de middelen voornamelijk innemen voor psychologische nood ${ }^{37}$ Salinsky schrijft dat $60 \%$ van de gebruikers hun kalmeringsmiddel voor het eerst kregen vanwege een crisis in hun leven (voor $13 \%$ van deze groep was dit rouwverwerking). De voorschrijvend arts gaf het volgens hen in $66 \%$ van de gevallen vanwege angst en in 53\% wegens depressie. ${ }^{32}$ Volgens Dunbar vormden slaapstoornissen, angst/depressie en trauma/epilepsie $91 \%$ van de gehanteerde indicaties. ${ }^{33}$ Van der Waals tot slot heeft gekeken of de indicatiestellingen (symptomen en diagnosen) woor prescriptie legitiem waren. De conclusie was dat aan vrouwen vaker dan aan mannen een benzodiazepine voorgeschreven werd zonder dat van relevante symptomen of diagnosen sprake was. In de groep $45-64 j \mathrm{j}$ was dit verschil statistisch significant, $45 \%$ versus $24 \%{ }^{6}$

\section{Kenmerken van de gebruiker}

*eslacht en leeftijd.

In de geselecteerde literatuur is de vrou w ten opzichte van de man in de meerderheid, variezrend van $1,5: 1$ tot $3: 1^{5,21,23,33,34,36-43}$ In 9 van de 15 studies komt naar voren dat het gebruik voor beide geslachten toeneemt met het stijgen van de leeftijd. $5,6,21,23,33,38,39,41,43$ Uit recent onderzoek van Van der Waals blijkt dat het verschi] in prevalentie van gebruik tussen vrouwen en mannen groter wordt, naarmate men ouder wordt. In de leeftijdscategorie van 15-45 jaar gebruiken mannen en vrouwen het middel in dezelfde lage frequentie: $2 \%$. In de categorie 45-64 gebruikt $10 \%$ van de vrouwen en $6 \%$ van de mannen; bij de groep ouder dan 65 is dit $16 \%$ van de vrouwen en $9 \%$ van de mannen. ${ }^{6}$ 
* Sociale en economische status.

Van de sociale status werden door Blijenberg en Ashton volgende determinanten voor langdurig gebruik genoemd: het weduwnaarschap, WAOer zijn en werkeloos zijn. ${ }^{38,41}$ In het onderzoek van Wells blijkt langdurig gebruik samen te hangen met een hoger inkomen terwijl Ashton een samenhang vindt tussen langdurig gebruik en lager inkomen. ${ }^{39,41}$ Laag opgeleiden blijken in 2 studies vaker te gebruiken. ${ }^{38,39}$ Financiele problemen en sociaal isolement worden alleen in de studie van Catalan genoemd als factor bij langdurig gebruik. ${ }^{23}$

* Ethnische afkomst.

De invloed van ethnische afkomst op gebruik van benzodiazepinen is slechts in twee studies onderzocht, waarbij blijkt dat mensen van het negroïde ras minder tranquillizers gebruiken. ${ }^{37,39}$ * Lichamelijke gezondheid en het gebruik van andere medicamenten.

In 8 studies blijken de gebruikers (waarvan 4 studies betreffende langdurig gebruikers) meer gezondheidsproblemen te hebben dan de niet-gebruikers. Drie van deze studies melden ook een hoger gebruik van non-psychotropica door de benzodiazepinegebruikers. Uit 3 studies blijkt dat in de gebruikersgroep meer andere psychofarmaca, zoals slaapmiddelen en antidepressiva in combinatie met het psychofarmacon, dat onderzocht werd, gebruikt worden. $5,21,33,38-40,42,43$

* Psychische gezondheid.

In twee onderzoeken is in de gebruikersgroep het hebben van psychiatrische problemen vaker aangetroffen dan bij de niet-gebruikers. ${ }^{23,40}$ Psychologische problemen (angst en neurotisch gedrag) zijn in vier studies vaker gezilen onder gebruikers dan onder niet-gebruikers. ${ }^{23,32,37,41}$ Dit gold eveneens voor psychische problemen (psychische stress, labiliteit en dysfunctioneren). $5,36,38,39$

* Gewoontevorming.

Het gebruik van genotmiddelen (koffie, tabak, alcohol) is slechts in éen studie als factor bij tranquilizergebruik gevonden, hetgeen alleen voor vrouwen blijkt te gelden. ${ }^{37}$ In de andere studies, warrin dit item onderzocht werd, blijkt geen verband te bestaan tussen gebruik van slaap-en/of kalmeringsmiddelen en gebruik van genotmiddelen.

Een overzicht van onderzoeksvariabelen, die significant verschillen tussen gebruikers en nietgebruikers, wordt gegeven in tabel 4. De meest in het oog springende verschillen betreffen geslacht, leeftijd en het hebben van gezondheidsproblemen. 
vabel 4. Overzicht wan de in 15 geselecteerde rtudies met controlegroep onderzochte psychofamaca en gevonden gebruikerskenmerken, die significant werschillend waren ten opzichte van niet-gebruikers.

nummers van gerefereerde studies ${ }^{\wedge}$

\begin{tabular}{|c|c|c|c|c|c|c|c|c|c|c|c|c|c|c|c|}
\hline middel(en) in onderzoek & 36 & 37 & 21 & 38 & 39 & 32 & 34 & 23 & 40 & 33 & 41 & 42 & 05 & 06 & 43 \\
\hline $\begin{array}{l}\text { psychotropica } \\
\text { slaap-en kalmerings- } \\
\text { sedativa } \\
\text { alle tranquillizers } \\
\text { minor tranguillizers } \\
\text { benzodiazepinen } \\
\text { benzodiazepinen * } \\
\text { benzodiazepinen * * } \\
\text { anxiolytica } \\
\text { hypnotica } \\
\text { antüdepressiva } \\
\text { antipsychotica }\end{array}$ & $\begin{array}{l}x \\
x\end{array}$ & * & $\begin{array}{l}x \\
x \\
x\end{array}$ & $\mathrm{x}$ & $\begin{array}{l}x \\
\mathcal{K}\end{array}$ & $x$ & $x$ & $\mathrm{x}$ & $x$ & $\mathrm{x}$ & . & $x$ & $\mathrm{x}$ & $x$ & $\begin{array}{l}\mathrm{x} \\
\\
\mathrm{x} \\
\mathrm{x}\end{array}$ \\
\hline Kenmerken gebruikers & & & & & & & & & & & & & & & \\
\hline 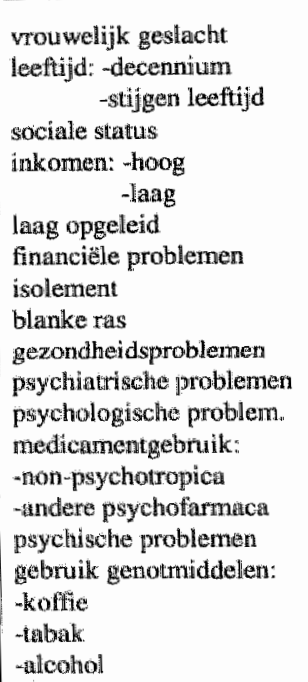 & $\mathrm{x}$ & $\begin{array}{l}\mathrm{x} \\
\mathrm{x} \\
\mathrm{x} \\
\mathrm{x} \\
\mathrm{x} \\
\mathrm{y} \\
\mathrm{y} \\
\mathrm{x}\end{array}$ & $x$ & $\begin{array}{l}\mathrm{x} \\
\mathrm{x} \\
\mathrm{x}\end{array}$ & $\begin{array}{l}\mathrm{x} \\
\mathrm{x} \\
\mathrm{x} \\
\mathrm{x}\end{array}$ & $\mathrm{x}$ & $\mathrm{x}$ & $\begin{array}{l}x \\
x\end{array}$ & $\begin{array}{l}x \\
x\end{array}$ & $\begin{array}{l}x \\
x\end{array}$ & $\begin{array}{l}x \\
x \\
x \\
x\end{array}$ & $\begin{array}{l}x \\
x \\
x\end{array}$ & $\begin{array}{l}x \\
x \\
x\end{array}$ & $\begin{array}{l}\mathrm{x} \\
\mathrm{x}\end{array}$ & $\begin{array}{l}\mathrm{x} \\
\mathrm{x}\end{array}$ \\
\hline
\end{tabular}

A vetgedrukt referentie mumer betreft studie van alleen langdurig gebruiker

BD*: benzodiazepinen exclusief hypnotica (day-time user) BD**: 10 meest gebruikte benzodiazepinen in afgelopen jear.

significantie: $x$ is positief en - is negatief werband $V=a l l e e n$ vrouwen verschilden $6=6$ decennium en hoger 6=alleen $6 \mathrm{e}$ decernium 


\subsection{Beschouwing}

Vergelijking van de onderzoeksgegevens uit deze literatuur-studie is moeilijk. Hiervoor zijn enkele redenen aan te geven:

-het type onderzoek verschilt: populatiesurveys versus praktijkonderzoek;

-de methode van dataverzameling varieert: interviews, enquêtering, dossier-analyse en consultregistratie;

-de onderzochte geneesmiddelen zijn niet in alle studies identiek: soms waren ook andere medicamenten dan benzodiazepinen in het onderzoek betrokken; in enkele studies is bimnen de groep benzodiazepinen geselecteerd, waarbij bijvoorbeeld de slaapmiddelen niet zijn meegenomen;

-de omschrijving van het gebruik varicert in de verschillende studies;

-de selectie van de onderzoekspopulatie is niet in alle studies hetzelfde: soms geen selectie (dat wil zeggen alle wijzen van gebruik), soms wel selectie, bijvoorbeeld langdurig gebruik.

Rekening houdend met deze beperkingen kan her volgende worden opgemerkt over de resultaten van deze literatuurstudie:

\section{Wijze wan gebruik}

In deze literatuur blijken verschillende begrippen gehanteerd te worden voor de wijze van gebruik: kortdurend en langdurig, eenmalig, periodiek en continu, dagelijks en niet-dagelijks gebruik. Voor het merendeel van deze begrippen zijn verschillende definities gebruikt. De begrippen langdurig, chronisch en regelmatig overlappen elkaar, waarbij enerzijds de duur va* rieert ( 6 tot 12 maanden) anderzijds het aantal herhaliacepten over die periode (bijvoorbeeld 24 recepten in een half jaar) verschillend is.

Om meer eenduidigheid te krijgen in de wijze van gebruik is het zinvol om eerst onderseheid te maken in kortdurend gebruik ( $<3$ maanden) en langdurig gebruik ( 23 maanden). Kortdurend gebruik kan eenmalig, én episade aaneengesloten zijn, of episodisch, dat wil zeggen meerdere episodes in die 3 maanden. Bij langdurig gebruik is deze verdeling in episodisch an aancengesloten (=continu gebinuik) ook te maken.

De keuze van 3 maanden als omslagpunt van kort naar langdurig gebruik is arbitrair. Er zijn een aantal argumenten om deze termijn te kiezen:

-het risico van verslaving is al aanwezig bij gebruik gedurende een tot enkele maanden. $12-13$ - de NHG-standaard gaat in de definitie van chronisch hypnoticagebruik wit van gebruik langer dan 3 maanden. 44 
-het Farmacotherapeutisch Kompas noemt langdurig gebruik langer dan \pm 4 maanden." -de receptuur woor chronisch gebruik van geneesmiddelen is gebonden aan en maximum aflevering voor drie maanden. (van psychofarmaca zelfs aan 1 maand).

Nader onderzoek zal moeten aantonen of deze arbitraire keuze van 3 maanden het juiste omslagpunt aangeeft.

\section{Indicatiestelling}

De naam "slaap-en kalmeringsmiddelen" impliceent als het ware de indicatie tot gebruik. Toch is de indicatiestelling van de huisarts niet altijd even duidelijk. Van der Waals e.a. vonden in hun onderzoek dat met name bij vrouwen benzodiazepines werden voorgeschreven zonder duidelijke indicatiestelling door de arts. Er zijn blijkbaar andere niet medische factoren, die het voorschrijven van benzodiazepinen mee bepalen.

Het feit dat herhaalrecepten voor benzodiazepinen veelal via de balie verstrekt worden, betekent dat de patient zelf een rol speelt bij het voortzetten van het gebruik van deze middelen. Slechts in één studie werd bij langdurig gebruikers het verloop van de hoevelheid medicatie onderzocht: $11 \%$ bleek uit eigen beweging de dosis te verhogen. ${ }^{33}$ Er werd geen literatuur gevonden betreffende de ideeèn van patiènten over indicatiestelling en/of klachten waarvoor ze benzodiazepinen gebruiken en veranderingen hierin op langere termijn.

Uit onderzoek in eigen praktijk bleek dat de patiënt gezondheidsproblemen het meest noemde als oorzaak van de klachten (veelal slapeloosheid en nervositeit/angst) waarvoor een slaap- of kalmeringsmiddel geslikt werd. ${ }^{20}$

\section{Kemmerken wan de gebruiker}

In tegenstelling tot de literatuur van begin zeventiger jaren, waanin de risicopatiènt de vrouw op middelbare leeftijd was, blijken in de door ons geselecteerde studies de oudere vrouwen de langdurig gebruikers te zijn. Andere kenmerken van gebruikers die naar woren komen zijn". het hebben van meerdere gezondheidsproblemen, psychologische problemen en een lage opleiding. Er blijkt geen verband te bestaan tussen gebruik van genotmiddelen gebruik van slaapen/of kalmeringsniddelen.

De controlegroepen in de geanalyseerde studies zijn samengesteld uit niet-gebruikers. Het vergelijken wan de verschillende groepen gebruikers zou het profiel van de langdurig gebruiker kunnen venduidelijken. 


\section{Tenslotte}

Elke huisartspraktijk heeft een groep langdurig gebruikers van sllaap-en kalmeringsmiddelen. De verstrekking van recepten zonder arts-patient contact houdt deze groep automatisch in stand. Pogingen om in deze te interveniëren vragen veel extra inzet van de huisarts. Daarom is het zeker zo belangrijk te anticiperen en de aandacht te richten op mensen die at risk zijn om langdurig gebruiker te worden. Van belang daarbij is op de hoogte te zijn van karakteristieken van de potentiële langdurig gebruikers op het moment van de eerste prescriptie. Enkele zajn hiervan op basis van dit onderzoek naar voren gekomen.

Veel vragen blijven echter onbeantwoord. Belangrijk is het een eenduidige indeling te maken in de diverse groepen gebruikers, opdat het vergelijken van onderzoeksgegevens van deze gebruikersgroepen beter mogelijk is. Daartoe werd hier een aanzet gegeven.

\section{Dankbetuiging}

Een woord van dank zijn we verchuldigd aan het Praeventiefonds, dat ons onderzoeksproject "chronisch Psychofarmaca gebruik in de eerste lijn" (projectnr. 28-2186) tinancieel ondersteunde. Dit literatuuronderzoek vormt eem onderdeel wan dit project. 


\section{Literatuur}

Ziekenfondsraad. Fammacother apeutisch Kompas 1997

Balter MO. Marheimer DL, Mellinger GD, Uhlenhuth EM A cross-nationall comparison of anti-anxiey/sedative drugs use. Curr Med Reis Opin $1984 ; 8$ (suppl 4) $5-20$

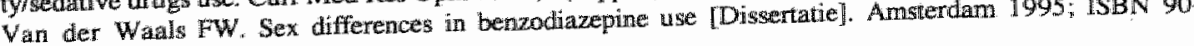
9008823.7

Andersun RM. Use of repeatedly prescribed medicines. I R Coll Gen Prant 1980; 30(219):609-13

Lagro-Janssen $T$. Liberton IJW. Profielen van regelmatge gebrukers van benzodiazepinen in een huisartspraktijk. Ned Tijdschr Geneeskd $1993 ; 137: 1969-73$

Van der Wasls FW, Mohs J, Foets M. Sex differences among recipients of benzodiazepines in Dutch general practice. Br Med I 1993; 307: 363-7

Plagge $\mathrm{H}_{*}$ Visiers $\mathrm{I}$. Pouts $\mathrm{K}$, et all. Het voorschrijver van genesmiddelen zonder arts-patient contact in de huistartspraktillk. Huisars Wet $1988 ; 31: 120-3$.

Minusterie wat Welzajn, Volkggezondheid en Culturur. Zorg getal (Z.I.G.) 1994. Rijswijk 1994.

Langendijk PNJ, van Loenen AC, van Heijst ANP. Overdosis flunitrazepam en enkele andere benzodiaze. pinen; erwaringen wan het National Vergiftingen Informatie Centrum. Ned Tijdschr Geneeskd 1986; $130(45): 2032-6$

Buckley $N$ A, Dawson AH, Whyte IM, OConnell DLO. Relative toxicity of benziodiazepines in overdose Br Med I 1995; 310:219-21

Cook PJ, Hugget A, Graham-Pole R. Savage IT. Hypnotic accumulation and hangover in elderly inpaLients: a controlled double-blind study of temazepam and nitrazepam. Br Med J 1983; 286:100-2

Van der Lam JW. Afhankelijkheid van benzodiazepinen: omvang, risico's en eventuele verschillen mssen de middelen onderling Ned Tijdschn Geneeskd 1984; 128:817-9.

Steenkiste wan $M_{3}$ Roeck de J. Afhankelijkheid en absti nentiewerschijnselen bij gebruik van benzodiazepinen. Ned Tijdschr Geneeskd 1986; 130(27): 1224-7

zhtman FG. Kort-en langwerkende benzodiazepinen. Ned Tijdschr Geneeskd 1988; 132(42): 1917-21

Rummans TA, Davis LJ, Morse RM, Ivnik RJ. Learning and memory impairment in older, detoxified, benzodiazepine-dependent patients. Mayo Clin Proc 1993; 68: 731-7

Nijdam SJ. Benzodiazepinen door de jaren heen. Practitioner 1992; $9(6): 349-52$

Herimgs RMC, Stricker BFICh, de Boer A, Bekker A, Sturmans F. Femurfracturen, vallen en het gebruik van benzodiazepines: dosering belangrijker dan eliminatie halfwaardetijd. Nederlands Tijdschrift voor Farmacotherapie 1995; $1: 2-9$

Anonymus. Stoppen met benzodiazepines. Gebu 1994;28 (12):98-101

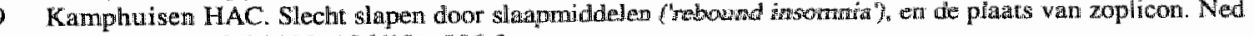
Tijofin Censeskd 1992; 136(12): 556-8

Visters FHJA, Knotmens JA, Van der Grinten RF. Van der Horst FGEM. Latgdurig gebnilk van sliap-en kalmeringsmiddelen in een huisantspraktijk. Huisarts Wet $1993 ; 36(12): 405-8$

Mellinger GD, Balter MB, thenmuth EH. Prevalence and conelates of long term regular use of anxioly tics IAMA 1984:251:375-9

Woods JH, Katz JL, Winger $\mathrm{G}$. Use and abuse of benzodizzepines. JAMA 1988; 260:3476-80

Catalan J, Guth D, all. General practice patients on long term psychotropic drugs. Br J Psychiatry 1988; 152: $399-405$

Simpson $R$, Power $K$, Wallate $L$, et all. Controlued comparison of the characteristics of long-tern benzodiaxepine users in general practice. Br J Gen Pract 1990; 40:22 6

King MB, Oabe J, Willams $P$, Rodrigo EK. Long term use of benzodiazepines; the wiews of patients. Br $j$ Gen Pract 1990; 40: 194-6

Holm M. One year follow up of users of benzodiazepines in general practice. Dan Med Bull 1990, 37: 18891

King MB. Is there still a role for benzodiazepines in general practice? Br J Gen Pract 1992; 42: 202-5 
28. Cormack MA, Sweeney KG, Hughes-Jones Foot GA. Evaluation of an easy, cost effective strategy for cutting benzodiazepine use in general practice Br I Gen Pract 1994;44:5-8

29 Matalon A, Yinnon A, Hurwitz A. Chronic use of hypnotics in a family practice - patients reluctance to stop treatment. Fam Pract 1990; 7: 258-60

30 Habraken $\mathrm{H}_{6}$ Blondeel $\mathrm{L}_{2}$ Soenen $\mathrm{K}$. Is langdurig gebruik van berzodiazepines zinvol? Huisarts Wat 1994: $37(7): 285-8$

31 Bashir $\mathbb{K}$, King $M$, Ashworth $M$. Controlled evaluation of brief intervention by generall practitioners to reduce chroric use of benzodiazepines. $\mathrm{Br}$ J Gen Pract 1994; 44: 408-12

32. Salinsky JV, Dore CI. Characteristics of long term benzodiazepine users in general practice. J R Coll Gen Pract 1987; 202-4

33 Dunbar GC. Perera MH. Jenner FA. Patterss of benzodiazepine use in Great Brittain as measured by general population surwey. Br J Psychiatry 1989; 155:836-41

34 Dunbar $\mathrm{GC}_{\text {, }}$ Morgan $\mathrm{DD}_{\mathrm{v}}$ Perera $\mathrm{KMH}$. The concurrent use of alcohol, cigarettes and caffeine in british benzodiazepine users as measured by a general population survey. Br J Addiction 1988; 83:689-94.

35 King MB. Long-term berzodiazepine users - a mixed bag. Addiction 1994; 89(1.1): $1367-70$.

36 Mellinger GD, Balter MR, Mannheimer DI, Cisin IH, Parry HJ. Psychic distress, life crisis and use of psychotherapeutic medications. Arch Gen Psychiatry 1978; 35: 1045-52.

37 Uhlenhuth EH, Balter MB, Lipman RS. Minor tranquillizers. Clinical correlates of use in an urban population. Arch Gen Psychiatry 1978: 35: 650-5.

38 Blijenberg-Ruis B, Garretsen HFL, Schuurman JH, Verdonk ALT. Het gebruik van slaap-en kalmeringsmiddelen. Een secundaire analyse van een Rotterdams onderzoek. T Soc Gezondheidsz 1986; 64: 491-7

39 Wells $\mathrm{KB}_{4}$ Kamberg $\mathrm{C}_{x}$ et all. Health status, sociodemografic faciors and the use of prescribed psychotropic drugs. Medical Care 1985; 23: 1295-1306

40 Gene-Badia J, Blay-Pueyo C, Soler-Vila M. Risk factors in the use of benzodiazepines. Fam Pract 1988; 5 : $283-8$

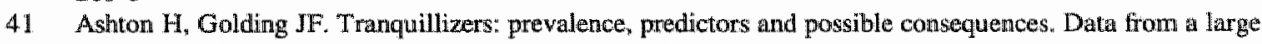
United Kingdom survey. Br J Addict 1989; 84: 541-6.

42 Simpson $\mathrm{RJ}$, Power KG, et all. Controlled comparison of characteristics of long-term benzodiazepine users in general practice. Br J Gen Pract 1990; 40: 22-6

43 Mant A, Mattick RP, de Burgh S, Donelly N, Haal W. Benzodiazepine prescribing in general practice: dispelling some myths. Fam Pract 1995; 12(1): 37-43.

44 Knuistingh Neven A, De Graaff WJ, Lucassen PLBJ, Springer MP, Bonsema K, Dijkstra R.H, FelixScollaart B. NHG-standaard Slapeloosheid en Slaapmiddelen. Huisarts Wet 1992; $35(5): 212-9$ 

hoofdstuk 5

\section{Interventies in de eerstelijn bij langdurig gebruik van benzodiazepinen.}

Een literatuuronderzoek.

Dit hoofdstuk is gepubliceerd als:

Vissers FHJA, Knottnerus JA, Van der Grinten RF, Van der Horst FGEM. Interventies in de eerste lijn bij langdurig gebruik van benzodiazepinen. Een literatuurstudie. Huisarts Wet $1997 ; 40(6): 244-7$ 


\section{Abstract}

Objective. To examine the effects of interventions in general practice to reduce long-term use of benzodiazepines.

Method. A Medline-search was done to find trials in general practice which studied interventions to withdraw or reduce long-term benzodiazepine use.

Results. Ten studies were found with several types of interventions for users; half of these trials used a letter, information sheet or consultation to make the users aware of the problem of long-term use. The follow-up in those studies was mostly short ( 3 to 8 months). In four controlled trials 18 to 50 procent stopped and 8 to 43 procent reduced using benzodiazepines. Two investigations found a relation between reduction and low baseline consumption. There were no differences between patients who were succesful or unsuccesful in reducing the medication in terms of sex, duration of use, strategy of reduction or type of practice; also there were no differences between several types of intervention.

Three trials concerned the prescribing behaviour of the general practitioner. Only in one of those studies a difference was found between intervention group and the control group.

Conclusion. No relevant differences in effectiveness have been found between several types of intervention. A simple action like sending an informative letter is quite as effective as intensive counseling during a period. To prevent long-term use is important.

Key words. general practice, benzodiazepines, long-term use, stopping. 


\subsection{Inleiding}

Slaap- en kalmeringsmiddelen worden vaak gebruikt, niet zelden gedurende een langere periode, en het is niet altijd gemakkelijk ermee te stoppen. De prevalentie van het gebruik van slaap- en kalmeringsmiddelen -veelal benzodiazepinen- was in 1987 in Nederland 6.9 procent. ${ }^{1}$

De prevalentie van langdurig gebruik (langer dan 12 maanden en dagelijks gebruik) in 1981 van de landen in Amerika en West-Europa bleek te variëren van 0.5 tot 5.8 procent; voot Nederland gold toen 1.7 procent. $^{2}$ In 1989 bleek in Nederland 30 procent van de gebruikers het slaap- of kalmeringsmiddel continu en langer dan 180 dagen te gebruiken. ${ }^{3}$

Het gebruik van benzodiazepinen heeft een aantal ongewenste neveneffecten, zoals bijvoorbeeld sufheid, vermoeidheid, geheugenverlies, coördinatiestoomissen en een katterig gevoel. ${ }^{4-10}$ Daarnaast kunnen bij langdurig gebruik tolerantie, afhankelijkheid en dientengevolge abstinentieverschijnselen optreden. $6,8,11,12$

Stoppen van langdurig gebruik wordt echter bemoeilijkt door enerzijds het optreden van rebound- en ontwenningsverschijnselen en anderzijds een hoge satisfactiegraad over de werking van het middel ${ }^{6,8,11,12}$ In enkele onderzoeken bleek dat 40-60 procent van de (langdurig) gebruikers het stoppen ter sprake had gebracht, de bereidheid getoond had onder begeleiding te stoppen, of een daadwerkelijke poging tot stoppen had ondernomen. ${ }^{13-17}$ Het spontaan stoppen van langdurig gebruik varieert in de verschillende onderzoeken van 12 tot 45 procent. $^{19-21}$

Tegen deze achtergrond rijst de vraag in hoeverre huisartsen langdurig gebruikers behulpzaam. kunnen zijn bij een poging om te stoppen. In deze literatuurstudie staan twee vragen centraal:

* Welke interventies gericht op het reduceten of stoppen van langdurig gebruilk van slaap-en kalmeringsmiddelen zijn uitgevoerd in de eerstelijn?

* Hoe effectief waren deze interventies?

\subsection{Literatune}

In Medline werden publicaties geselecteerd van 1962-1995. Een eerste selectie werd gemaakt op het steekwoord benzodiazepine; deze selectie werd weer gekoppeld aan de volgende steekwoorden: reduction/discontinue/stop, general practice/eerstelijn. De referenticlijsten van de artikelen werden gebruikt on verdere relevante publikaties op te sporen. Bij de selectie richtten we ons op twee soorten onderzoek: patiëntgebonden onderzoek en onderzoek naar beinvloeding van voorschrijfgedrag van (huis)artsen. Verdere criteria waren: gebruik wan een controlegroep en een follow-up van minimaal 3 maanden. 
De search leverde vectien interventie-onderzoeken in de eerste lijn op: 11 patiëntgebonden onderzoeken en drie gericht op het voorschrijfgedrag van de arts. Daarnaast werden zes beschouwende artikelen gevonden.

\subsection{Patiëntgericht onderzoek}

De kenmerken van 11 patiëntgerichte onderzoeken zijn vermeld in tabel 1. Het selecteren van de onderzoekspopulaties geschiedde veelal op basis van het afleveren van herhaalrecepten in een bepaalde periode of aan de hand van patiëntendossiers. In sommige onderzoeken werd tevens geselecteerd op leeftijd en/of een specifieke groep benzodiazepinen. Het succespercentage varieerde voor stoppen van 0 tot 63 procent, en voor reductie van gebruik van 0 tot 48 procent.

Slechts vier onderzoeken waren uitgevoerd met een controlegroep (zie ook tabel 2). In deze onderzocken werd geadviseerd het gebruik van slaap- en/of kalmeringsmiddelen geleidelijk te stoppen dan wel te reduceren.

De toegepaste interwenties verschillen nogal. Vooral het onderzoek van Gilbert et al. springt eruit vanwege de intensieve interventie. 28

De effectmeting werd op verschillende manieren uitgevoerd. Cormack et al bepaalden de reductie en het stoppen aan de hand van het aantal tabletten dat in een bepaalde periode werd geconsumeerd. ${ }^{23,30}$ Gilbert et al. maten alleen het aantal stoppers. Bashir et al. gaven de totale reductie (inclusief de stoppers) per groep weer aan de hand van de vermindering van de prescriptie. Het percentage stoppers in deze onderzoeken varieerde van 18 tot 50 procent, het percentage 'minderaars' van 8 tot 43 procent.

Cormack et al. vonden dat personen met een lage gebruiksdosis statistisch significant meer stopten of minder gingen gebruiken. ${ }^{23}$ Er werd geen verband gevonden met sekse, leeftijd, dur van gebruik, type interventie, type benzodiazepine, methode van afbouw van medicatie of type praktijk. In een tweede studie vonden Cormack et al. dat ouderen een statistisch significant beter resultaat hadden dan jongeren; er werd geen verband gevonden met sekse type benzodiazepine, type praktijk, type interventie en reden van gebruik (anxiolyticum of hypnoticum). Bashir et al. vonden bij 'night-time users' een statistisch significant grotere prescriptiereductie dan bij de controlegroep; dit verschil werd niet gevonden bij de 'day-time users'. Verder vonden zij een correlatie tussen het gebruik van antidepressiva bij het laatste meetpunt van het onderzoek en de reductie van het benzodiazepinegebruik. Er werd ook een correlatie gevonden tussen de prescriptiereductie en het gebruik van een lage dosis of het gebruik van een kortwerkend preparaat. Er werd geen verband gevonden tussen de reductie en de duur van het gebruik, ziekten, type praktijk en/of arts. 


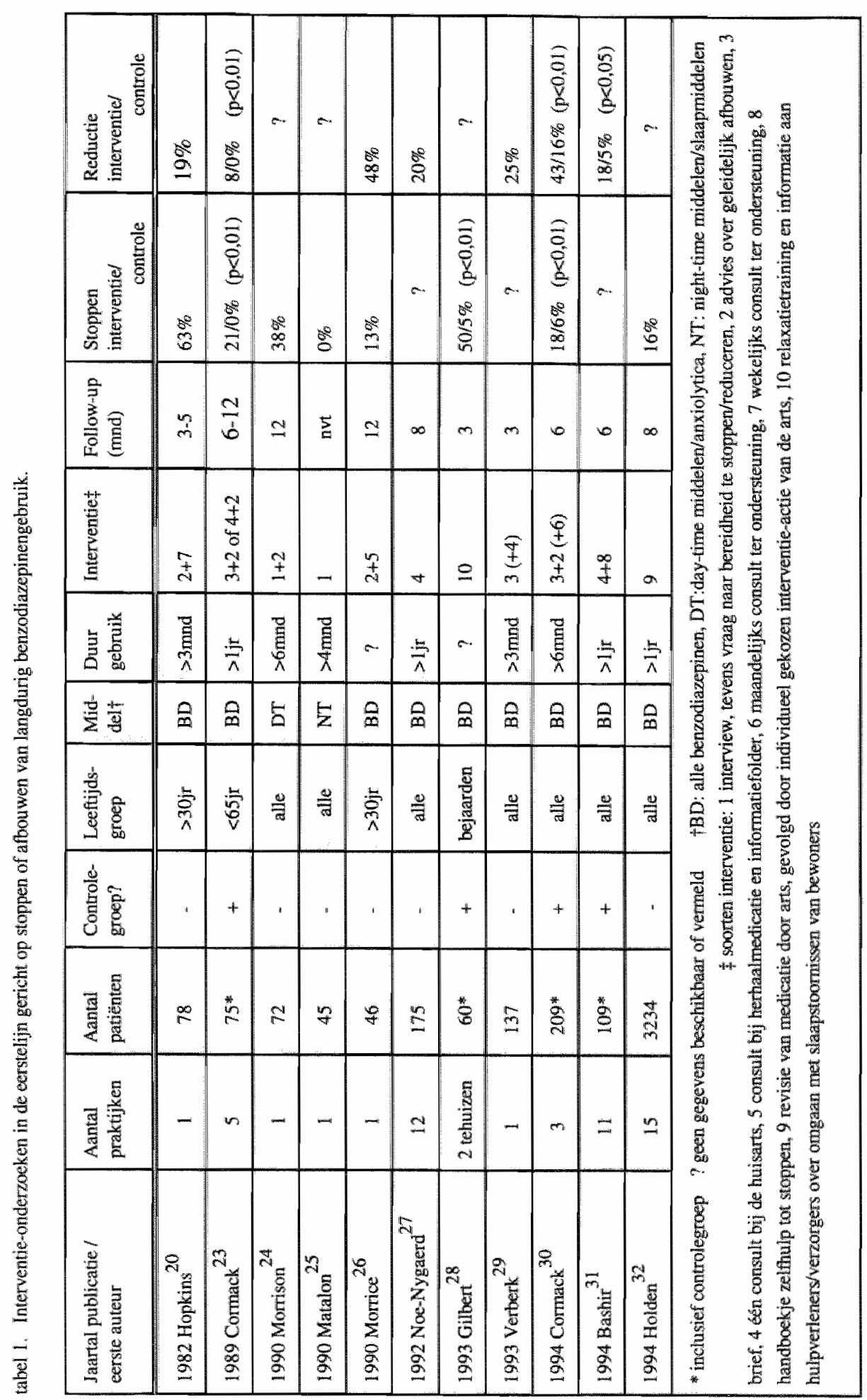


Wabel 2. Genanterde exclusiectiteria in de vier interwentiestudies (met controlegroep).

\begin{tabular}{|c|c|c|c|c|}
\hline Exclusiecriveria & Cormack $^{23}$ & Gilloert $^{28}$ & Commack $^{30}$ & Bashir ${ }^{31}$ \\
\hline Dekend met (risico) allcoholgebruik & + & & + & + \\
\hline \multicolumn{5}{|l|}{ In behande thing bif: } \\
\hline prycholoog & + & & & \\
\hline psychiater & + & & & + \\
\hline sudere arts die bemadiazepinen wororschrijt & & & + & \\
\hline Prychose & & & + & + \\
\hline Demerntie & & + & + & \\
\hline \multicolumn{5}{|l|}{ Crists of giekte: } \\
\hline benzodiatzepinem medisch noodzakelijk & $\frac{5}{3}$ & & + & + \\
\hline actuele crisis slut deelname uit & & + & & + \\
\hline Analfaberisme & & & + & \\
\hline Enquuetering onmogelijk & & & & + \\
\hline Bedlegerigheid & & t & & \\
\hline Gehandicapt & & & & + \\
\hline Abouw schadelijk voor patient & & & & + \\
\hline
\end{tabular}

Gilbert et al. onderzochten de effecten van het stoppen op het geestelijk functioneren. Zij vonden geen statistisch significant verschil in slaapsatisfactie, de score op de Mini Mental State Examination (MMSE) en het subjectief gevoel van welbevinden; wel werd na stoppen significant hoger gescoord op de Positive and Negative Affect Scale (PANAS). Bashir et al. vonden dat het reduceren van gebruik geen effect had op contactfrequentie en optreden van psychische problemen.

\subsection{Artsgericht onderzoek}

Er werden drie onderzoeken gewonden die betrekking hadden op het voorschrijfgedrag van huisartsen voor en na interventie. ${ }^{33.35}$ In alle drie de onderzoeken werden de participerende huisartsen in drie groepen verdeeld:

- een groep die eenmalig - schriftelijke of mondeling - informatie kreeg over de werking en indicaties van benzodiazepinen;

- een groep, die deze informatie schriftelijk én mondeling (persoonlijk met follow-up) kreeg; in één studie van đeze groep werd ook nog informatie over eigen voorschrijfgedrag gegeven ${ }^{33}$;

- een groep die geen informatie kreeg. 
Holm vond een algemene vermindering van de prescriptie, maar geen significante verschillen tussen interventiegroepen en controlegroep. ${ }^{33}$ Hartlaub et al. vonden geen verschil in verandering van prescriptiegedrag in de onderzochte groepen. ${ }^{34}$

Berings et al. vonden een statistisch significant verschil in prescriptie-reductie tussen de interventiegroepen en de controlegroep: in de groep die naast schriftelijke ook persoonlijke informatie kreeg ( $n=44)$ werd een reductie gevonden van 24 procent; in de groep die alleen schriftelijke informatie ( $n=43$ ) $\mathrm{kreeg}$, was dat 14 procent en in de controlegroep $(n=41) 3$ procent $(\mathrm{p}<0,05)^{35}$

\subsection{Beschouwing}

Langdurig gebruikers van benzodiazepinen minderen of stoppen ook zonder specifiek georganiseerde interventies met deze medicatie; dit blijkt zowel uit de controlegroep van drie van de vier patiëntgerichte interventiestudies $28,30,31$, als ook uit de onderzoeken van Salinsky \& Dore, Holm en Packham ${ }^{19-21}$. Welke factoren hierbij een rol spelen is niet duidelijk. Na patiëntgerichte interventies is er globaal genomen drie maal vaker sprake van reductie of stoppen dan zonder gecontroleerde interventie. In de vier geselecteerde onderzoeken vond bij stoppen een geleidelijke afbouw plaats, hetgeen men ook terugvindt in de adviezen aan de Nederlandse huisarts. 11

Het trekken wan conclusies uit de gecontroleerde onderzoeken is niet zonder meer mogelijk: de onderzoekspopulaties waren beperkt van omwang, de onderzochte leeftijdsgroepen stemden niet volledig overeen, en minderen en stoppen werden niet in alle gevallen gescheiden weergegeven. Niettemin lijkt het erop dat een eenmalige interventie in de zin wan schriftelijke dan well mondelinge informatievoorziening een significante reductie van gebruik (inclusief stoppen) tot gevolg heeft. Daarbij is een samenhang gevonden met een lage gebruiksdosis maar niet met sekse, duur van gebruik en type praktijk. Er lijkt geen verschil te zijn in het effect wan diverse vormen van interventie, hetgeen suggereert dat een eenvoudige handeling als een brief sturen hetzelfde resultaat heeft als maandelijks intensieve ondersteuningsgesprekken. ${ }^{23}$

Ten aanzien van enkele onderzoekswariabelen zijn de resultaten niet eenduidig: leeftijd lijkt geen rol te spelen, alhoewel in één publicatie gemeld werd dat ouderen een significant beter resultaat hadden. ${ }^{30}$ Dit geldt ook voor het type benzodiazepine: in eén onderzoek werd een positief verband gevonden met de kontwerkende preparaten. ${ }^{31}$ Alhoewel slechts in een publicatie onderzocht, is het opvallend dat er een verband is met het gebruik van antidepressiva aan het eind van de studie. ${ }^{31}$ 
Artsgerichte interventies met als doel verandering in prescriptiegedrag hebben uiteenlopende resultaten; het sterkste effect bleek te bestaan in het geval van persoonlijke informatie en intensieve feedback op de prescriptie. ${ }^{33.35}$ Slechts in één van de drie gevonden onderzoeken werd een statistisch significant verschil tussen interventie- en controlegroep vastgesteld. ${ }^{35}$

Pogingen om te interveniëren in het langdurig gebruik van slaap- en kalmeringsmiddelen vragen een grote inzet van de huisarts. Deze dient een gedragsverandering te bewerkstelligen bij de patiênt en/of bij zichzelf. Vooraf dient te patiënt echter inzicht te krijgen in het feit dat langdurig gebruik van benzodiazepinen in de regel niet zinvol is. Het cenmalig geven van informatie ormtrent gepast gebruk van benzodiazepinen blijkt wel effect te hebben, maar de resultaten van interventies bij langdurig gebruik van benzodiazepinen zijn niet overweldigend. Het stoppen van langdurig gebruik kan vergeleken worden met de aanpak van alcoholverslaving - een moeizaam proces. ${ }^{36}$ Het is belangrijk on te anticiperen en de aandacht te richten op mensen die at risk zijn om langdurig gebruiker te worden. Kennis omtrent karakteristieken van gebruik en gebruikers is daarbij onontbeerlijk.

\section{Dankbetuiging}

Een woord wan dank zijn we verschuldigd anan het Praewentiefonds, dat ons onderzoeksproject "chronisch psychofarmadcagebrik in de eerte lijn" (projectnt. 28-2186) financieel ondersteunde. Dit literatuuronderzoek vormo een
ondendeel wan dit project. 


\section{Literatuur}

1 Van der Walids EW. Sex differences in benzodiazepine use [Dissertatie]. Amsterdam 1995; ISBN 909008823-7

2. Balter MB, Manheimer DI, Mellinger GD, Uhenhuth EH. A cross-national comparison of anti-anxiety/sedative drugs use. Curr Med Res Opin 1984; 8(suppl 4):5-20

3 Herings RMC. Effecten van chronisch en gecombinferd geneesmiddelengebruik. Utrecht, Universiteit van Utrecht. 1989

4 Cook PJ, Hugget A, Graham-Pole R, Sawage IT. Hypnotic accumulation and hangover in elderly inpatients: a controlled double-blind study of temazepam and nitraxepam. Br Med J 1983;286:100-2

5 Van der Laan JW. Afhankeligheid vam benzodiazepinem: omvang, risico"s en eventuele verschillen tussen. de middelen onderling. Ned Tijdschr Geneeskd 1984; 128:817-9.

6 Steenkiste wam $M_{0}$ Roeck de 3 . Afhankelijkheid en abstinenteversehijnselen bij gebnik wan benzodiazepinen. Ned Tijdschr Geneeskd 1986; 130(27): 1224-7

7 Zitman FG. Kort-en langwerkende benzodiazepinen. Ned Tijdschr Geneeskd 1988: 132(42):1917-21

8 Rummans TA, Davis LJ, Morse RM, Jwnik RJ. Learning and memory impaiment in oldef, detoxified, benzodiazepine-dependent patients. Mayo Clin Proc 1993;68:731-7

9 Nijdam SI. Benzodiazepinen door de jaren heen. Practitioner $1992 ; 9(6) ; 349-52$

10 Herings RMC, Stricker BHCh, de Boer $A$, Bakker $A$, Sturmans F. Femurtracturen, vallen en het gebruik van benzodiazepines: dosering belangrijker dan eliminatie halfwaardetijd. Nederlands Tijdschrift voor Farmacotherapie 1995:1:2-9

11. Anonymus. Stoppen met benzodiazepines. Gebu 1994; 28 (12): 98-101

12 Kamphuisen HAC. Slecht slapen door slatapmiddelen ("rebound insomnia"), en de platats van zoplicon. Nied Tijdschr Geneeskd 1992; 136(12): 556-8

13 Dunbar GC. Perera MH, Jenner FA. Patherns of benzodiazepine use in Great Brittain as measured by general population survey. Br I Psychiatry 1989; 155:836-41

$14 \mathrm{King} \mathrm{MB}$. Is there still a role for benzodiazepines in general practice? Br I Gen Pract 1992; 42: 202-5

15 Wright $\mathbb{N}$, Caplan $R$, Payne $\mathbf{S}$. Community survey of long term daytime nse of benzodiazepines. Br Med I 1994: $309: 27-8$

16 Vissers FHJA, Knottnerus JA, Van der Grinten RF, Van der Horst FGEM. Langdurig gebruik van slaap- en kalmeringsmiddelen in en huisartspraktijk. Huisarts Wet 1993; 36(12): 405-8

17 Habraken $\mathrm{H}$, Blondeel L, Soenen $\mathrm{K}$ Is langdurig, gebruik van benzodiazepines zinwol? Huisarts Wel 1994 ; $37(7): 285-8$

18 Lagro-Janssen ALM, Liberton IJW. Benzodiazepinen: prohielen van chromische gebruikers in een huisartspraktijk. Ned Tijdschr Geneesk 1993; 137(39): 1969.73

19 Salinsky $\mathrm{IV}_{\mathrm{n}}$ Done $\mathrm{CJ}$. Characteristics of long term benzodiazepine users in general practice. J R Coll Gen Prnct 1987; 202 24

20 Holm M. One year follow up of users of benzodiazepines in general practice. Dan Med Bull 1990; $37: 18.8$ 91

21 Packharn C. Patients who hawe discontinued long-tem benzodiazepine treatnuent. Br J Gen Pract 1.992; 42: 130

22 Hopkins DR, Sethi KBS, Mucklow JC. Benzodiazepine withdrawal in general practice. J Coll Gen Pract $1982 ; 32 ; 758-62$

23 Cormack MA, Owens RG, Dewey ME. The effect of minimal interwentions by general practitioners on long term benzodiazepine use. J R Coll Gen Pract 1989; 39:408-11

24. Morrison JM. Audit and follow-up of chronic benzodiazepine tranquillizer use in general practice. Fann Pract 1990; 7: 253-7.

25 Matalon $A_{4}$ Yimon $A$. Hurwitz A. Chronic use of hypnotics in a familly practice - patients reluctance to stop treatment. Fam Pract 1990, 7: 258-60

26 Morrice A, lliffe $\mathrm{S}$. Advising patients on their benzodiazepine use. Br J Gen Pract 1990; 40; 83

27 Noe-Nygaard $\mathrm{E}_{\mathrm{z}}$ Oveser. LC. Is it possible to change long werm benzodiaxepine consimption by counseling in general practice? Ugeskr Laeger $1992 ; 154(37): 2485-8$.

28 Gilbert A, Owen N, Lnes IM, Sansom L. Trial of an imtervention to reduce chronic benzodiazepine use among residents of aged-care accomodation. Aust $\mathrm{N} Z \mathrm{ZJ}$ Med 1993; 23(4):343-7. Verberk H. Benzodiazepines: (voor wie) zijn ze een probleam? Patient Care 1993: 34 46 
30 Cormack MA, Sweney KG, Mughes-Iones Foot GA. Evaluation of an easy, coust efective stratugy for cutting benzodiazepine use in general practice Br 1 Gen Pract 1994; 44:5-8

31 Bashit K, King M, Ashworth M. Controlled evaluation of brief intervention by general practioners to reduce chronic use of benzodiazepine: Br J Gen Pract 1994; 44: 408-12

32 Holden JD, Hughes IM. Tree a. Bemzodiazepine prescribing and withdrawal for 3234 patients in 15 general practices. Fam Pract $1994: 11: 358 \cdot 62$.

33 Holm M. Intervention against long-term use of hypnotics sedatives in general practice. Scand $\$$ Prim Heal th Core 1990,8(2): 1 13-7.

34. Hartaub PP. Barret PH, Marine WM, Murphy JR. Evaluation of an intervention to change benzodiazepine prescribing behaviour in a prepaid group practice setting. Am I Prew Med 1993; 9(6): 346-52

35 Berings D. Blondeel L. Habraken $H$. The effect of industry-independant drug information on the prescribing of benzodiazepines in general practice. Eur J Clin Pharmacol 1994:46(6): 501-5

36 Anonymus. Standasrd NHG. Problematisch alcoholgebruik. Huiarts Wet $1990 ; 33(7): 280-5$ 
hoofdstuk 6

\section{Van probleemstelling naar vraagstelling}





\subsection{Inleiding}

Psychofarmaca behoren tot de meest voorgeschreven geneesmiddelen in de Nederlandse gezondheidszorg. In 1996 had én op de vijf woorgeschreven geneesmiddelen betrekking op het centraal zenuwstelsel (figuur 1 )

figuur 1. Geneesmiddelengebnik naar anatomie, jaarcijfers 1996.

Bron: Stichting Farmaceutische Kengetallen (SKF), data en feiten 1997

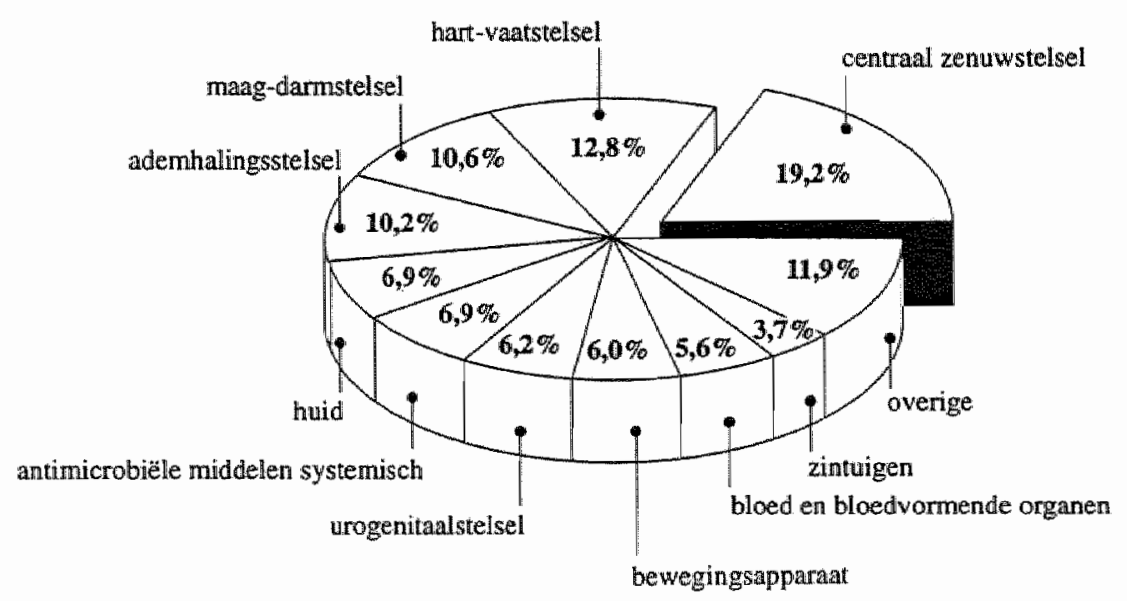

Uit door de SKF gepubliceerde cijfers over 1995 bleek oxazepam, een benzodiazepine dat als slaap-en kalmeringsmiddel wordt voorgeschreven, met 2,1 miljoen voorschriften de tweede plaats te bezetten in de lijst wan in Nederland meest gebruikte geneesmiddelen (figur 2). Opmerkelijk is dat in de eerste lijn slaap-en kalmeringsmiddelen waak zonder arts-patiëntcontact worden verstrekt in de vorm van herhalingsreceptuur. Dit werd nog eens bevestigd door ons vooronderzoek naar het voorkomen van baliereceptuur. Realiseent de huisarts zich wel dat hiermee chronisch gebruik in stand wortd gehouden?

Aan het langdurig gebruik van slaap- en kalmeringsmiddelen kleven nadelen. Bijwerkingen zijn er vooral op gebied wan het centraal zenuwstelsel, zowel als gevolg van intoxicatie als ook. 
bij therapeutische doseringen. Langdurig gebruik leidt tot afhankelijkheid en tolerantie. Als men al het gebruik zou willen stoppen of minderen, wordt dit bemoeilijkt door fenomenen als "recurrence" (terugkeer van de klachten) of "rebound" (tijdelijke terugkeer in versterkte mate van klachten die vór het gebruik reeds bestonden). Bij definitief staken van het gebruik zullen ontwenningsverschijnselen overwonnen moeten worden. Uit ons literatuuronderzoek bijkt dat het terugdringen van langdurig gebruik in de eerste lijn een moeizaam proces is. Is het zinvol om te beworderen dat personen die langdurig gebruiker zijn hun gebruik eindigen? Hoe is nu de mening van de gebruiker en de voorschrijvend arts ten aanzien van dit langdurig gebruik? Is er bereidheid daar verandering in aan te brengen?

figuiur 2. Top-10 geneesmiddelengebruik. Aantal voorschriften (x1000) afgeleverdin 1995

Bron: Stjchting Farmaceutische Kengetallen, data en feiten 1996

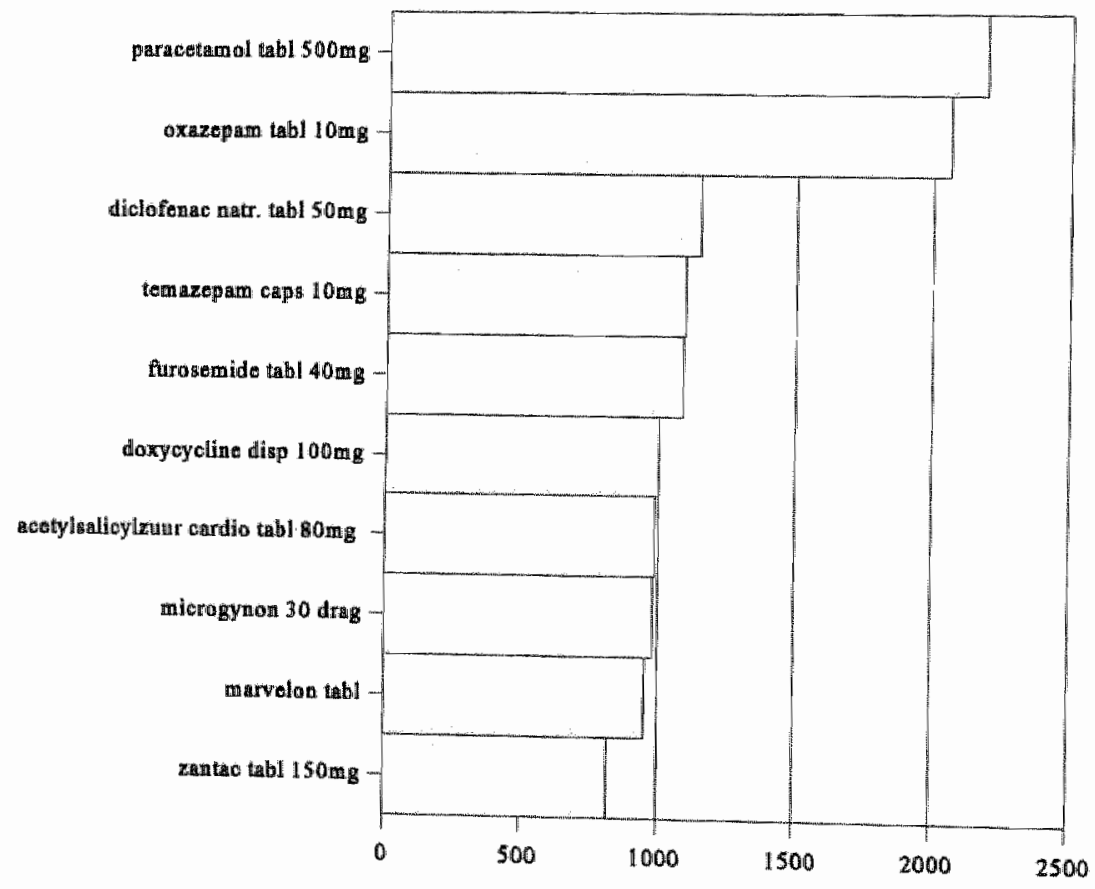

In thet licht van het voorgaande is het van belang te voorkómen dat jemand langdurig gebruiker van slaap-en/of kalmeringsmiddelen wordt (een vorm van primaire preventie). In dit kader is het belangrijk te weten wie risico loopt langdurig gebruiker te worden. Om dit te weten is kennis omtrent het profiel van de langdurig gebruiker noodzakelijk. 
Rondom het voorschrijven en gebruik van slaap- en kalmeringsmiddelen neemt de huisarts een sleutelpositie in, immers:

- veel psychische en psychosomatische problemen, die aan de huisarts gepresenteend worden, kunnen leiden tot het woorschrijven van psychofarmaca;

- de huisarts staat vaak aan het begin van het prescriptiebeleid en is daarom de beslissen. de persoon bij de overgang van eenmalig naar langdurig gebruik;

- de huisarts heeft een goed overzicht over de aan zijn patiënten voorgeschreven medicamenten en kan uit dien hoofde een bewakende en begeleidende rol vervullen.

Teneinde de preventie en het terugdringen van het langdurig gebruik van slaap-en kalmeringsmiddelen te bevorderen, is meer inzicht nodig in factoren, die tot dit gebruik bijdragen:

- factoren samenhangend met het medicament zelf, met name de effectiviteit en nadelige effecten zoals gewenning en tolerantie;

- factoren samenhangend met het stellen van de indicatie tot het gebruik en het aanwezig blijven daarvan;

arts- en praktijkgebonden factoren, zoals voorschrijfgedrag, kennis, wijze van voorlichting geven en praktijkorganisatie;

- patiëntgebonden factoren, waarbij gedacht kan worden aan geneigdheid tot langdurig gebruik van stemmingsbeïnvloedende middelen zoals genotmiddelen, ongaan met stress;

- $\quad$ sociale en situationele factoren, zoals levensgebeurtenissen, eenzaamheid.

\subsection{Vraagstellingen}

Het onderhavige onderzoek richt zich voomamelijk op patiënt- en medicamentgebonden factoren. Deze keuze is gebaseerd op het feit dat patiënten een sterk bepalende rol lijkt hebben bij langdurig gebruik, hetgeen ondermeer blijkt uit het blijven voortbestaan van werstrekking van herhaalreceptuur voor psychofarmaca zonder arts-patièntcontact. Uiteraard is de vraag dan van belang in hoeverre er werschil is tussen de visie van de patiènt en die van de huisarts ten aanzien van het gebruik. Wat doet de huisaits als er een verschil is? Ervaren levens gebeurtenissen, de manier van omgaan ermee (coping), persoonskenmerken, gebruik van genotmiddelen en het hebben van problemen met eigen gezondheid zijn in dit kader de patientgebonden variabelen voor dit onderzoek (figuur 3). 
figur 3. Stroomdiagram; circult wan onderzoek
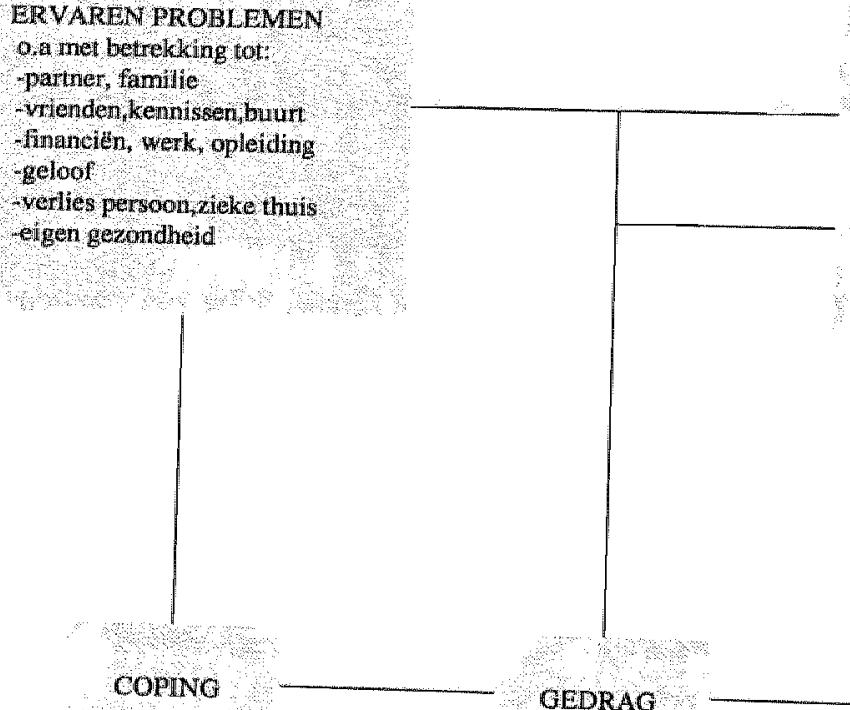

PERSOONSKENMERKEN

achitergrondvariabellen

werksituatie

eenzaamheid

\section{GEZONDHEID}

1

GEWOONTE

gebruik van:

-koffie

talcohol

tabak

\section{COENNG}

GEDRAG

NON-COPING
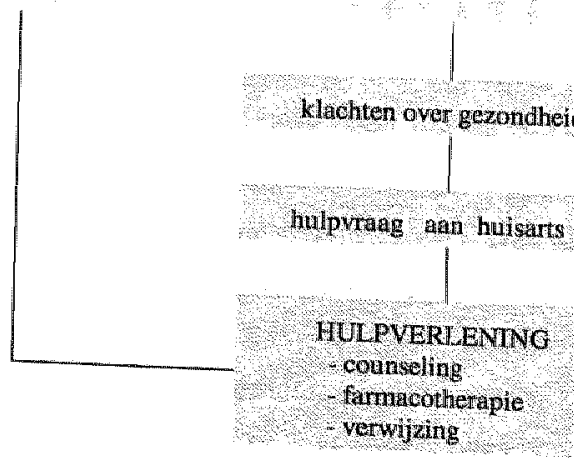
In het onderzoek staan de volgende vraagstellingen centraal:

1. In welke mate hangen aspecten van het dagelijks leven (zoals consumptie van genotmiddelen, levensgebeutenissen, stress en omgaan met stress/"coping") en van gezondheid samen met incidenteel, episodisch, respectievelijk continu gebruik van slaap-en kalmeringsmiddelen? (hoofdstuk 8)

2. In welke mate is er een samenhang tussen de aanleiding tot het voorschrijven en de kenmerken hiervan enerzijds en het incidenteel, episodisch of continu (gaan) gebruiken van slaap-en kalmeringsmicldelen anderzijds? (hoofdstuk 8 )

3. In hoeverre wordt het langdurig gebruik van slaap-en kalmeringsmiddelen als een probleem ervaren en in hoeverre is er belioefte/bereidheid om te stoppen? (hoofdstukken 9 en 12)

4. In welke mate zijn er verschillen tussen gebruikers van slaap- en kalmeringsmiddelen en niet-gebruikers wat betreft het ervaren van gebeurtenissen in het dagelijks leven en/of gezondheid?

(hoofdstukken 10 en 11 ) 

boofdstuk 7

Methode van onderzoek, populatie-opbouw en procedure, data-analyse en respons. 



\subsection{Methode}

\section{Algemeen}

Het onderzoek betreft een post-enquêtestudie, waarin patiènt en huisarts geënquêteerd werden ten aanzien van het gebruik van slaap- en kalmeringsmiddelen. Het werd uitgevoerd in 11 huisartsenpraktijken (solopraktijken, associaties en gezondheidscentra), waarin 33 huisurtsen werkzaam waren voor 56900 patiënten. Alle waren aangesloten bij het RegistratieNet Huisartspraktijken (RNH) van de Universiteit Maastricht (UM). De selectie van psychofarmacagebruikers vond, afhankelijk van de mogelijkheden per praktijk, plaats op twee manieren: een voorselectie door apothekers of een populatie-survey. Er werd een controlegroep van nietgebruikers geselecteerd, gematched op basis van leeftijd en geslacht, telkens uit dezelfde praktijk.

Voor het onderzoek werd gebruik gemaakt van het geautomatiseerde RNH-bestand warin zijn opgenomen leeftijd en geslacht, patiënt-achtergrond gegevens (burgerlijke staat, woonverband, opleiding, verzekeringsvorm), en probleemlijsten (als onderdeel van de medische verslaglegging). De probleemlijst van een patiènt bevat alle voor de gezondheid relevante problemen en diagnosen. Als probleem wordt beschouwd datgene waarvoor nader onderzoek of handelen door 'werkers in de gezondheidszorg' nodig is of iets dat het lichamelijk of geestelijk welzijn van de patiênt kan verminderen of heeft verminderd. Op basis van deze definitie horen onder andere diagnoses (diabetes mellitus), klachtenpatronen (chronische rugklachten), afwijkende uitslagen of bevindingen (PAPsmear klasse IV), risicofactoren (drugsgebruik, belaste familie-anamnese) en allergische reacties op de probleemlijst thuis. Alleen die problemen worden opgenomen die consequenties hebben voor de functionele toestand van de patiënt en/of de prognose. Qua tijd kan een probleem permanent, chronisch (langer dan 6 maanden), of recidiverend zijn. De gezondheidsproblemen worden geregistreend met behulp van da Interna tional Classification of Primary Care (ICPC), met gebruikmaking van de geactualiseerde criteria van de International Classification of Health Problems in Primary Care (ICHPPC-2defined). ${ }^{1,2,3.4}$ Dit RNH-bestand wordt beheerd door het Medisch en Maatschappelijk Informatie Centrum (MEMIC). De RNH-populatie is wat demogafische gegevens betreft vergelijkbaar met de Nederlandse bevolking. ${ }^{2}$

\section{Procedure en meetinstrumenten}

De onderzoekspopulatie is geselecteerd uit de ingeschrewen patiënten van 30 jaar en ouder. Voor deze benedengrens van leeftijd werd gekozen op basis wan de ervaring in de pilotstudie. ${ }^{5}$ De onderzoekspopulatie ontving een post-enquête (zie bijlage 2), die vragen omvatte omtrent achtergrondgegevens, medicatiegebruik in het jaar voorafgaand aan het verzenden van de enquête, gebruik van genotmiddelen (koffie, tabak en alcohol), ervaren lichamelijk en psychisch 
welbevinden, alsook de wolgende meetinstrumenten: Eenzaamheidslijst, Hopkinslijst, Utrechtse Copinglijst, een vragenlijst ter detectie van excessief alcoholgebnik (CAGE-lijst), Groningse Lijst Langdurige Moeilijkheden en een schaal voor Kwaliteit van leven. ${ }^{6-12}$ De score van de Eenzaamheidslijst is een maat voor eenzaamheid en als zodanig voor het ontbreken van saciale steun. Met de Hopkinslijst kunnen op een kwantitatieve wijze de aard en emst gemeten worden van psychoneurotisch en/of somatisch onwelbevinden (het gaat om de ervaren pathologie van de onderzochte). De Copinglijst meet het reageren op stressvolle gebeurtenissen (copinggedrag). De CAGE-lijst geeft weer of er sprake is van alcoholverslaving. De Groningse lijst inwentariseert langdurige moeilijkheden; deze lijst werd op empirische basis aangevuld met drie items: 'moeilijkheden in verband met het verlies van een dierbaar persoon', 'moeilijkheden in verband met het verzorgen wan een chronisch zieke of een invalide persoon thuis" en 'moeilijkheden in verband met eigen gezondheid'. Op de schaal voor 'Kwaliteit van leven' kan de ervaren $k$ waliteit van leven visueel aangegeven worden.

Uit de beantwoording van de enquête en üt de voorselectie van de apotheken werd bekend wie slaap-en/of kalmeringsmiddelen gebruikt hadden. Van de respondenten had namelijk $35 \%$ het slaap- en /of kalmeringsmiddel, dat ze gebruikt hadden volgens de apotheekgegevens, niet vermeld. Door de twee gegevensbestanden met elkaar te vergelijken werd de kans uitgesloten dat een patiẻnt-gebruiker ten onrechte niet herkend werd ten gevolge van recall bias. ${ }^{13}$ Aan de patiënt-gebruikers werd 3 maanden na de eerste enquête een tweede gestuurd (zie bijlage 3 ) met vragen, die betrekking hadden op (het) gebruikte slaap-en/of kalmeringsmiddel(en), óok aan de personen die vergeten hadden dit middel te vermelden. Deze tweede vragenlijst bevatte vragen over de aard en omvang van dit medicamentgebruik, verdeeld in drie tijdvakken (periode vóor 1 oktober ' 92 , periode van 1 oktober ' 92 tot 1 oktober "93, periode vanaf 1 oktober "93); daarmaast bevatte de lijst ook vragen over satisfactie, bijwerkingen en stoppogingen, alsook een medicijnverslavingsindex. ${ }^{14}$

Naast enquêtering van de patiënten werden aan de huisartsen van de participerende praktijken vragenlijsten voorgelegd omtrent de patiënt-gebruikers en hun gebruik van slaap- en kalmeringsmiddelen. De enquête bevatte vragen omtrent receptverstrekking, indicatie voor gebruik, gedrag van de patiënt en stoppogingen.(zie bijlage 4)

\subsection{Opbouw onderzoekspopulatie en procedure van onderzoek}

Selectie van onderzoekspopulatie.

Oorspronkelijk was het de bedoeling on de selectie van de gebruikers in de 11 RNH-praktijken geheel te laten plaatsvinden door apothekers. Gegeven de discussie in 1993 omtrent de 
uitwoering van de Wet op de Persoonsregistratie (WPR) bleek een kJeine groep apothekers niet bereid de voorgestelde procedure te volgen. ${ }^{15-18}$

figuur l. Stroomdiagram. Opbouw onderzoekspopulatie van gebruikens (G) en niet-gebnaikers (NG). Aantallen en responspercentages

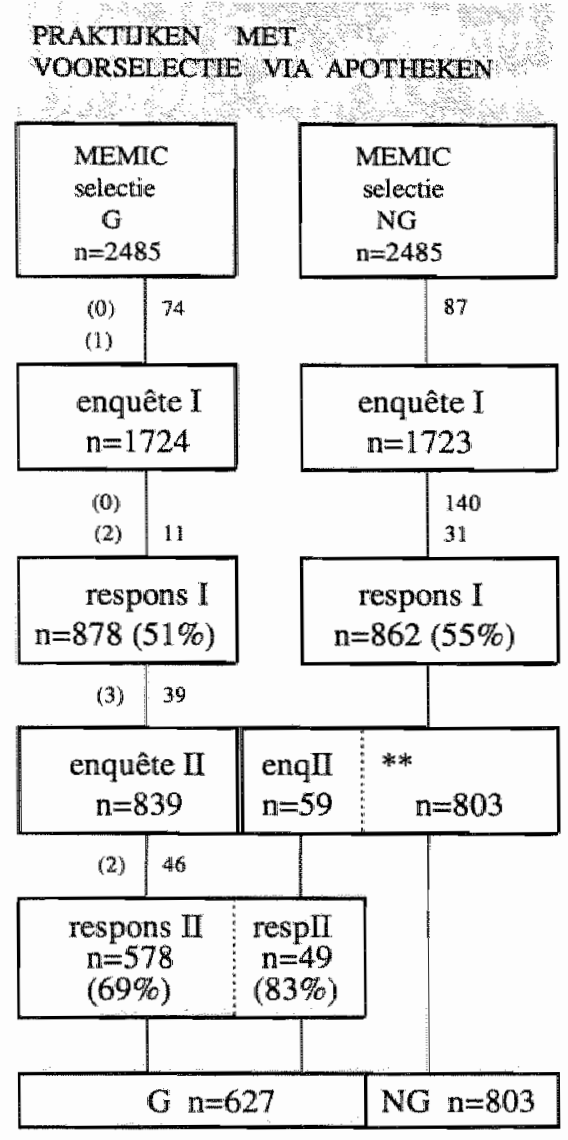

\section{PRAKTIJKEN ZONDER VOORSELECTIE VIA APOTHEKEN}
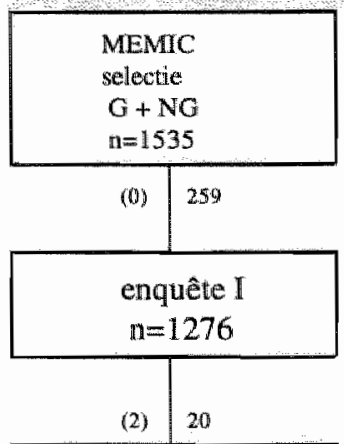

12
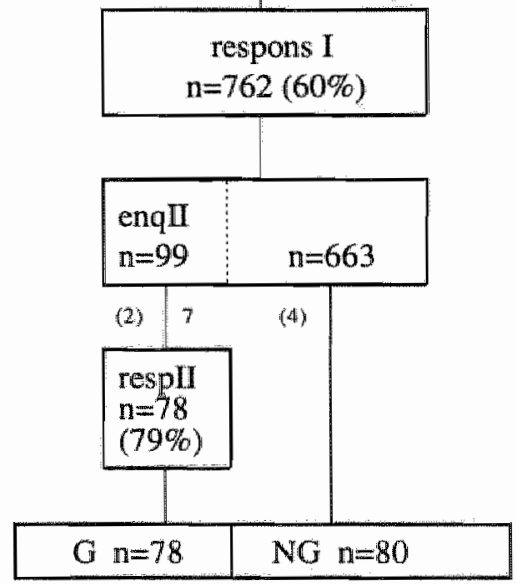

\section{totaal GEBRUIKERS $\mathrm{n}=705$ totaal NIET-GEBRUIKERS $\mathrm{n}=883$}

noot (O). Exclusies door huisartsen; woor criteria zie tabel 1.

noot (1): Op basis wan geschate grootte van onderzoksbesitand werd een steekprof benaderd. noot (2): Uitval tijdens het onderzoek (bij enquete 1 en 2); voor omschrij ving zie tabel 3 . woot (3): Uitval tijdens het omderzok (bij enquete I) doot foutieve apotheckselectic. noot (4): Matching van controlepersomen op geslacht en leeftij wan gebruikers-respordenten. * Urit de enquêtegegevens bleken ook in de controlegroep gebruikers voor te komen, die niet bekend waren in het apothekersbestand. Deze personen werden alsnog als gebrujkers in de anallyse betrokken. 
tabel 1. Exchsicctiteria bij de selecie, verdeeld over de praktijken. Aantallen.

a) De gebruikerggroep.

\begin{tabular}{|c|c|c|c|c|c|c|c|c|c|c|}
\hline \multirow{2}{*}{$\begin{array}{l}\text { piralk- } \\
\text { ijt }\end{array}$} & \multicolumn{4}{|c|}{ groepen exclustectiterig } & \multirow[b]{2}{*}{5} & \multirow[b]{2}{*}{6} & \multirow[b]{2}{*}{7} & \multirow[b]{2}{*}{8} & \multirow[b]{2}{*}{9} & \multirow[b]{2}{*}{ totakil } \\
\hline & 1 & 2 & 3 & 4 & & & & & & \\
\hline 1 & - & 6 & 1 & 1 & 1 & - & - & 2 & - & 11 \\
\hline 2 & 4 & 2 & 1. & * & 2 & $=$ & - & 1 & - & 10 \\
\hline $4^{* * *}$ & - & 6 & 7 & 1 & 6 & 2. & 1 & 16 & 210 & 249 \\
\hline 5 & 3 & 4 & 3 & 1 & 2 & 1 & 1 & 1 & - & 16 \\
\hline 9 & - & - & 1 & - & - & - & $=$ & 6 & - & 7 \\
\hline 10 & - & - & - & - & - & \% & . & - & . & 0 \\
\hline 14 & - & - & $=$ & . & " & - &. & 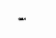 & 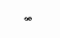 & 0 \\
\hline 15 & - & 4 & 1 & 3 & 1 & - & 1 & 2 & - & 12 \\
\hline 16 & . & $=$ & 2 & 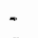 & 1 & . & - & 2 & $=$ & 5 \\
\hline 17 & - & 3 & 3 & 2 & 1 & - & . & - & - & 9 \\
\hline 18 & 1 & 7 & 4 & - & - & - & $=$ & 2 & $\cdots$ & 14 \\
\hline toleat & 8 & 32 & 23 & 8 & 14 & 3 & 3 & 32 & 210 & 333 \\
\hline
\end{tabular}

b) De controlegroep. (exdusief praktip $2+4$ )

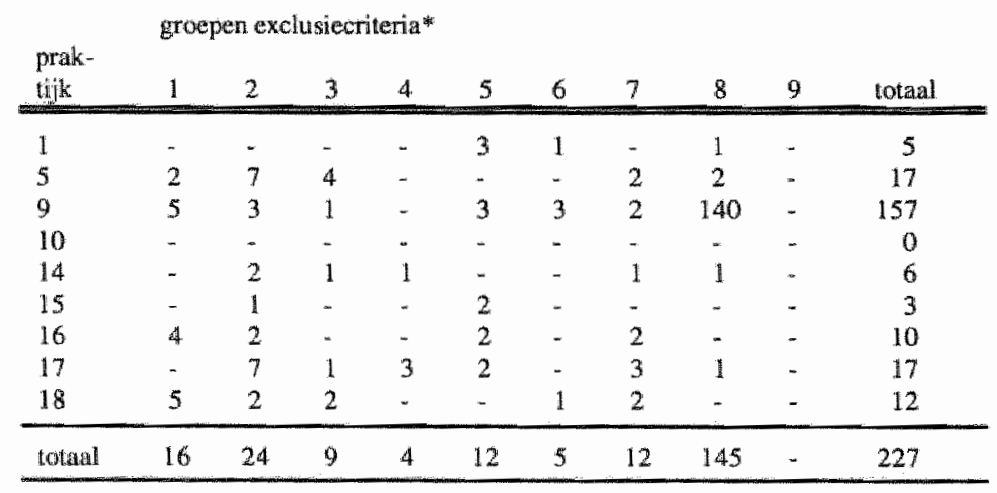

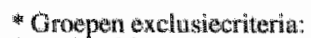

1: taalprobleem, and fabeer

2: on psychische redenen niet in stat mee to doen: depressie, psychose, achterdochtig, demerit, labiel, recent wedume(nanr), versilanfe

3: ort lichantigke redenen niat us staat nee te doen: te ziek, teminan zek, opgenomen in ziekenhuis, CVAafasie, catchoom

4: werstandelijk gehandicapt

5: verhuisd, guat verhuizen, andere huisurts

6. vorwach onbetrouwbatr resultatiat bij enquatering, geen interesse te participeren in onderzoek

$7:$ overleden

8: dubbel in hestand, wiet te vinden in praktikgegevens, verkecrde leeftidselectie, tijdelijk niet op woonadres, werkerde selectie bij controlegroep (op ants, is gebruilker), geen reden angegeven.

$9 ;$ in praktijk 4 werden personen ouder dan 70 jaar $(n=2) 6)$ uitgeloten van deelname, vanwege participatie aan een ander onderwok

* Praktijk $2+4$ zijin gebnikers è kontrolepersonen (zonder voorselectie).

Daardoor was het noodzakelijk de praktijken te verdelen in twee groepen wat betreft de wijze van selectie van patiënten:

a) Van negen praktijken werd door de huisartsen aan de apothekers, die het merendeel van hun patiënten van medicamenten voorzagen, gevraagd een selectie te maken van patiënten van 30 
jaar en ouder, die in de periode vanaf 1 oktober " 92 tot 1 oktober "93 slaap-en/of kalmerings" middelen afgehaald hadden. Deze overzichtslijsten werden beheerd door de huisarts(en) en/of assistente(s) en waren slechts voor hen en voor de huisarts-onderzoeker toegankelijk. Deze lijsten bleven in de praktijken; gegevens die voor het onderzoek nodig waren, werden in geanonymiseerde vorm overgenomen. Slechts deelnemers, die ook in het RNH-bestand voorkwamen, kwamen in aanmerking voor selectie. Aldus ontstond er een bestand van 2485 personen. Door het MEMIC werd voor dit bestand een even grote groep controlepersonen geselecteerd, gematched op leeftijd (geboortejaar), geslacht en praktijk (figuurl).

Beide bestanden werden in de praktijken nog eens gecontroleerd op geschiktheid tot deelname. Van de gebruikersgroep werden op deze wijze 74 personen geëxcludeerd en van de controlegroep 87 (tabel 1). Vanwege de omvang van dit bestand en de geschatte benodigde grootte van de te onderzoeken gebruikersgroep werd at random de helft van de geselecteerde populatic schriftelijk benaderd met het verzoek tot deelname; bij de eerste beoordeling van de respons bleek deze echter te laag, reden waarom van twee praktijken alsnog de totale selectie benaderd werd (figuur 1). Na correctie op exclusiecriteria en verzending van enquêtes reageerden 878 gebruikers, respectievelijk 862 controlepersonen. Uit de gegevens van de enquêtes van de controlegroep bleken er gebruikers voor te komen die niet voorkwamen in het apothekersbestand ( 59 personen). Deze werden overgeheveld naar de gebruikersgroep en als gebruiker in de analyse betrokken (figuur 1). Zodoende werd aan 898 gebruikers de vervolg-enquête gestuurd, waarin vragen gesteld werden over aard en omvang van dit medicamentgebruik.

b) In twee praktijken werd, vanwege de onmogelijkheid van selectie door apothekers, een populatie-survey gehouden om gebruikers van slaap- en kalmeringsmiddelen op te sporen. Een op de drie mensen van 30 jaar en ouder werd door het MEMIC uit het RNH-bestand geselecteerd. In én praktijk werden 210 personen, ouder dan 70 jaar, uitgesloten van deelname, omdat dezen in een ander onderzoek participeerden. Aan de geselecteerde patienten $(n=1276)$ werd per post de eerste enquête gestuurd met het verzoek om deel te nemen aan het onderzoek (figuur /). Degenen, die aangaven een slaap- en/of kalmeringsmiddel gebruikt te hebben. $(\mathrm{N}=99)$, ontvingen de vervolgenquête met vragen over de aard en omvang van dit medicamentgebruik. Uit de respondenten/niet-gebruikers $(\mathrm{N}=661)$, werd een controlegroep geselecteerd, gematched op leeftijd, geslacht en praktijk (figuw 1 ). Het resultaat van dit alles was een totaal bestand van 78 gebruikers en 80 controlepersonen. De gezamenlijke onderzoekspopulatie kwam aldus op 705 gebruikers (G) en 883 niet-gebruikers (NG).

\section{Tijdpad van enquêtering}

De selectie van de onderzoekspopulatie vond plaats in oktober en november 1993. Het verzenden van de eerste enquête werd gestart in december 1993. Drie maanden later werd aan de gebruikers de tweede enquête gestuurd. In beide enquêtes werd aan de geẻnquêteerden toè- 
stemming gevraagd hem/haar telefonisch te benaderen als antwoorden op vragen in de enquête niet duidelijk waren of ontbraken.

Na de enquêtering van de patiënt-deelnemers werden in oktober 1994 de 33 artsen van de participerende praktijken geënquêteerd ten aanzien van het gebruik van slaap- en kalmeringsmiddelen door hun patienten. Tevens ontvingen de huisartsen van de praktijken, waarin voorselectie door de apothekers had plaatsgevonden, eenzelfde enquête betreffende een steekproef wan non-responders wit de gebruikersgroep.

\subsection{Data-analyse}

\section{Verwerking van gegevens}

De antwoorden wan de enquêtes werden met bchulp van thet Statistical Package for the Social Sciences (SPSS) bewerkt en geanalyseerd. ${ }^{19}$ De gebruikers van slaap-en/of kalmeringsmiddelen werden, op basis van de gegevens ower het gebruik, verdeeld in twee groepen: kortdurend gebruikers (maximaal 3 maanden) en langdurig gebruikers (langer dan 3 maanden). Kortdurend gebruik werd onderscheiden in eenmalig (één episode/periode) en kortdurend-episodisch (meerdere episodes/periodes). Langdurig gebruik werd onderverdeeld in langdurig-episodisch en continu gebruik. (figuur 2)

figuur 2. Indeling in categorieèn van gebruik van slaap-en kalmerningsmiddelen.

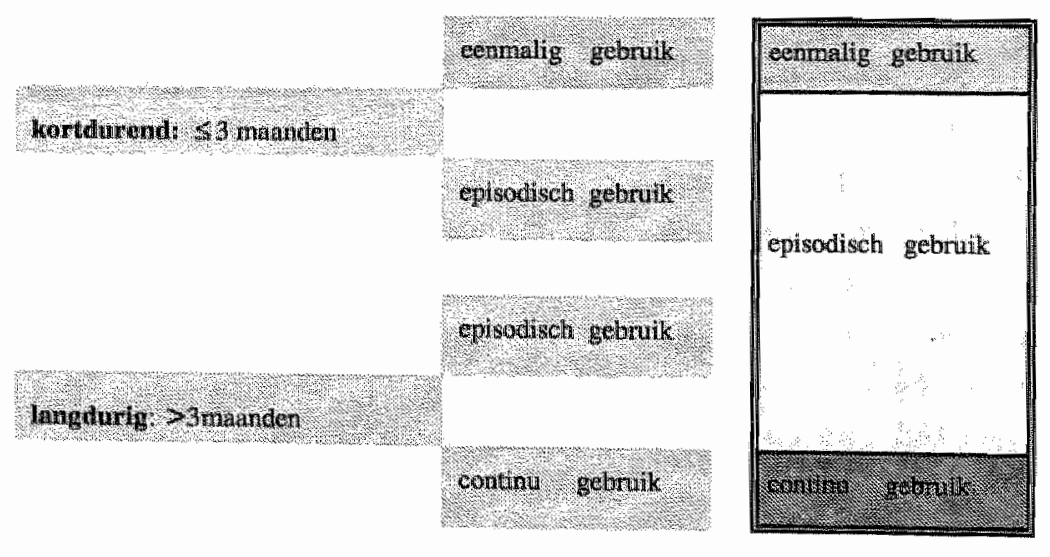

Deze vier groepen wenden vergeleken met betrekking tot patiënt-achtergrondgegevens (leeftijd, geslacht, burgerlijke staat, woonverband, opleiding, verzekeringsvorm), reden voor gebruik van het medicament, probleemverwerking, coping, ervaren gezondheid, sociale steun, gebruik van 
genotmiddelen, satisfactie en ondernomen stoppogingen. De mening van de patiënten over hun medicatiegebruik werd vergeleken met die van hun huisarts. Voor zover van toepassing werden de onderzoeksgegevens van gebrulkers- en controlegroep met elkaar vergeleken. Van alle groepen werden de probleemlijsten vergeleken.

tabel 2. Betrouwbaarheid en inteme consistentie van de MVI-index (gecorrigeerd ${ }^{14}$ en na verwijdering van item $10)$.

\begin{tabular}{|c|c|c|c|c|}
\hline \multirow[b]{2}{*}{ ITEM* } & \multicolumn{2}{|c|}{$\begin{array}{l}\text { MVI-corrected } \\
\text { standard a .6820 } \\
\text { Cronbach } \alpha .5315\end{array}$} & \multicolumn{2}{|c|}{$\begin{array}{l}\text { MVI-corrected } \\
\text { exclusive item } 10 \\
\text { standard } \alpha .7334 \\
\text { Cronbach } \alpha .7130\end{array}$} \\
\hline & $\begin{array}{l}\text { corrected item / } \\
\text { total correlation }\end{array}$ & $\begin{array}{l}\text { a if item } \\
\text { deleted }\end{array}$ & $\begin{array}{l}\text { corrected item / } \\
\text { total correlation }\end{array}$ & $\begin{array}{l}\alpha \text { if item } \\
\text { deleted }\end{array}$ \\
\hline 1 & .4751 & .4589 & .4991 & .6744 \\
\hline 2 &, 1506 & .5270 & 11331 & .7155 \\
\hline 3 & 3279 & .4940 & 3967 & .6904 \\
\hline 4 &, 3799 & 4794 & 4264 & 6847 \\
\hline 5 & 3505 & 5001 & 3746 & 6969 \\
\hline 6 &, 3529 & .5005 & 6339 & 6925 \\
\hline 7 &, 1504 & 5226 & 2456 & 7090 \\
\hline 8 &, 2349 &, 5139 & .2926 & 7036 \\
\hline 9 & .3070 & .4808 & 3878 & 6999 \\
\hline 10 & -2115 & 7130 & & \\
\hline 11 & .3440 & .4788 &, 3838 &, 6892 \\
\hline 12 & 4040 & 4589 & 4153 & .6843 \\
\hline 13 &, 3348 & 47.46 & 3752 &, 6934 \\
\hline
\end{tabular}

*items van de index:

1 : is medicament meer gebruikt dan is toegestaan door huisarts?

2: is in loop van tijd dosis wan middel verhoogd?

3: zijn in loop van tijd aan huisarts andere sterkere middelen gevraagd?

4: kwam u tabletten van dit middel tekort?

5: vroeg u wel eens extra tabletten van dit middel aan anderen?

6: hebt u wel eens gernerkt dat meer van middel genomen moest worden voor gewenst effect?

7 : hebt $\mathrm{w}$ lichamelijke klachten gehad door het innemen wan dit niddel?

8: heeft het nemen van dit middel tot conflikten geleid met familie, vrienden, werk, school of met politie?

9. hebt u emotionele of psychische problemen gehad tijdens het gebruik?

10: hoe tevreden bent u over de werking van het middel?

11 : hebt $u$ well eens een slaap- of kalmeringsmiddel gebruikt om $u$ prettiger of meer ontspannen te voelen, zonder dat dit was voorgeschreven?

12: gebruikt u wel eens allcohol bij dit medicament?

13: gebruikt a wel aens alcohol om u ontspannen te voelen of goed te slapen? 
De afhankelijkheid van het slaap-en/of kalmeringsmiddel is gemeten met behulp van een medicijnverslavingsinder (MVT). ${ }^{14}$ Deze is opgebouwd vit wragen, waarvan een gedeelte afkomstig is van meetinstrumenten, die betrekking hebben op drugs- en alcoholgebruik en de gevolgen daarvan. 2024 De index bevat 13 scores en is verdeeld in vier dimensies: "drugseeking" gedrag, stoppen en ontwenning, voor-en nadelen van gebruik en roes- en kick-effect van het middel. Ter beoordeling van de interne consistentie van de MVI-lijst werd de Crohnbach's alpha ( $\alpha$ ) bepaald ${ }^{25}$ Deze bedroeg 0,45 . De volgens De Berk gecorrigeerde scone (met weglating van 3 scores) was 0,53 . De subscore omtrent 'tevredenheid over werking' had een sterk negatieve invloed op de $\alpha$. Door dit item niet mee te nemen in de bepaling wan de $\alpha$ steeg deze naar 0,71 (tabel 2). Dat is de reden dat we gebruik maakten van deze aangepaste versie, zonder het item 'tevredenheid over werking van het middel'. Wel werd de subscore "tevredenheid over de werking" apart als variabele geanalyseerd.

De score van de MVI-index had een variatie van 0 tot 42 : hoe hoger de score hoe sterker het verslavingsgedrag.

Voor de besproken onderwerpen in de hoofdstukken 8-11 werd een selectie gemaakt van onderzoeksgegevens uit de 3 enquêtebestanden ( 2 patiènten-enquêtes en 1 arts-enquête).

\section{Statistische analyse}

In SPSS werden de data opgeslagen en bewerkt. De data zijn per groep gepresenteerd door middel van percentages of gemiddelden en standaardafwijkingen. De groepen van langdurig gebruikers (langdurig-episodisch en langdurig-continu) werden vergeleken met de kortdurendeenmalig gebruikers. Voor de bivariate analyse (analyse per variabele) werd voor de nominale schalen de Chi-kwadraat ( 2 2)-toets of de exacte toets van Fisher gebruilkt. Voor de ordinale schaleen werd de T-toets of de Mann-Whitney (MW)-toets gehanteerd. Er werden vier significantie-niveaus onderscheiden: $0,05,0,01,0,005$ en 0,001 .

Door middel van logistische regressie is nagegaan welke variabelen geassocieerd zijn met de groepsindeling, na correctie voor andere variabelen. Langdurig gebruikers zijn vergeleken met kortdurend-eenmalig gebruikers en langdurig-continu met langdurig-episadisch. Bovendien is door middel wan reductie van het model geprobeerd een zo goed mogelijke voorspelling te maken van langdurig gebruik. 


\subsection{Uitval en non-respons analyse}

\section{Vitval}

De uitvallers, dat wil zeggen de patiënten die de enquête retourneerden met opgave van reden om niet meer mee te doen, en de enquêtes die achteraf niet bruikbaar bleken voor het onderzoek, zijn weergegeven in tabel 3 .

tabel 3. Uitvall bij enquête I (E I) en enquête II (E II). Uitgesplitstit woor praktijken mét en voor praktijlken zónder selectie door apothekers. Aantallen per gebrukers (G) en controlegroep/ niet-gebruikers (NG).

\begin{tabular}{|c|c|c|c|c|c|c|}
\hline \multirow[b]{2}{*}{ categorieën uitval } & \multicolumn{2}{|c|}{$\begin{array}{l}\text { praaktijken ms* } \\
G\end{array}$} & \multicolumn{2}{|c|}{$\begin{array}{c}\text { praktijken ms } \\
\mathrm{NG}\end{array}$} & \multicolumn{2}{|c|}{$\begin{array}{c}\text { praktijken } z s^{* *+} \\
G+N G\end{array}$} \\
\hline & EI & EII & E I & $\mathrm{E} \Pi$ & EI & EII \\
\hline patieiènt onbekend & . & - & 1 & geen & - & - \\
\hline verhuisd, andere huisarts & 6 & 1 & 10 & & 17 & - \\
\hline slechte kwaliteit invulling enquête & 3 & 12 & 2 & & 2 & 1 \\
\hline overleden & . & 1 & 6 & & 1 & . \\
\hline medicament niet gebruikt/voor partner & - & 10 & - & & - & 2 \\
\hline lich./psych. niet in staat mee te doen & - & 3 & 2 & & - & - \\
\hline recall problemen & . & 2 & . & & . & $\ldots$ \\
\hline gebruik buiten registratieperiode & - & 13 & - & & 。 & 4 \\
\hline verkeerde leeftijdselectie & 2 & - & 5 & & . & - \\
\hline onbekend/missing & w & 4 & 5 & & - & - \\
\hline totalal & 11 & 46 & 31 & 0 & 20 & 7 \\
\hline
\end{tabular}

* praktijken met selectie (ms) door apothekers

** praktijken zonder selectie (zs) door apothekers

\section{De non-respons op de eerste enquête.}

Vanwege de verschillende selectiestrategieën werden beide groepen praktijken ten aanzien van de non-respons apart geanalyseerd. Verder werd voor de praktijken met apotheekvoorselectie een steekproef van gebruikers non-respondenten getrokken, waarover de huisartsen geënquêteerd werden.

a) praktiiken mét voorselectie

Voor de gebruikersgroep was de non-respons op de eerste enquête $48 \%$. Vergelijken we de witeindelijk in het onderzoek opgenomen gebruikers-respondenten met de non-respondenten van de eerste enquête dan blijkt dat de non-responsgroep meer ouderen bevat, meer laagopgeleiden, meer ziekenfondsverzekerden en meer mensen die geen partner hebben en/of alleenstaand zijn. In hun probleemlijst staan minder actieve problemen, terwijl er geen verschil is in het aantal inactieve problemen. (tabel 4). 
$\mathrm{Bij}$ de controlegroep was de non-respons $44 \%$. Bij vergelijking met de respondenten werden dezelfde verschillen gevonden als bij de gebruikersgroep, met uitzondering van het gegeven dat bij de non-respondenten minder vrowwen waren en dat ze in hun probleemlijst minder inactieve problemen hadden. (tabel 5)

tabel 4. Gebruikers (G). Non-respons van de cerste enquête versus respons in praktijken met selectie door apothekers. Aantallen, percentages. Verschillen getoetst met Chi-kwadraat en Mann-Whitrey toets. Tabellen: exclusief missings.

\begin{tabular}{|c|c|c|c|c|c|}
\hline \multirow[b]{2}{*}{ variabele } & \multicolumn{2}{|c|}{$\begin{array}{l}\text { non-respons enquête } \\
\qquad(\mathrm{n}=835)\end{array}$} & \multicolumn{2}{|c|}{$\begin{array}{l}\text { respons enquête } \mathbb{I} \\
\qquad(\mathrm{n}=627)^{*}\end{array}$} & \multirow[b]{2}{*}{$p$} \\
\hline & $\%$ & (n) & 胞 & (n) & \\
\hline geslacht vrouwelijk & 67.7 & $(548)$ & 65,4 & $(410)$ & ns \\
\hline leeftìjd $30-39$ & 12,3 & $(100)$ & 13,8 & (86) & 0,005 \\
\hline $40-49$ & 18,0 & $(146)$ & 17,4 & (109) & \\
\hline $50-59$ & 16,2 & (131) & 20,8 & $(130)$ & \\
\hline $60-69$ & 21,0 & $(170)$ & 26,1 & (163) & \\
\hline 270 & 32,5 & $(263)$ & 21,9 & $(137)$ & \\
\hline opleiding laag & 78,8 & $(637)$ & 67,6 & $(409)$ & 0,000 \\
\hline middel & 18,6 & $(150)$ & 24,5 & (148) & \\
\hline hoog & 2,6 & $(21)$ & 7,9 & $(48)$ & \\
\hline verzekering verplicht & 82,6 & $(669)$ & 72,5 & $(441)$ & 0,000 \\
\hline particulier & 17.4 & $(141)$ & 27,5 & $(167)$ & \\
\hline solo" ja ja & 43,2 & $(350)$ & 31,1 & (189) & 0,000 \\
\hline nee & 56,8 & $(460)$ & 69,9 & $(418)$ & \\
\hline \multicolumn{6}{|l|}{ actieve problementh } \\
\hline 0 & 22,2 & (180) & 9,4 & $(59)$ & 0,000 \\
\hline$\|$ & 11,6 & (94) & $11_{n} 5$ & (72) & \\
\hline $2-5$ & 49,2 & (398) & 49,5 & (309) & \\
\hline $6-10$ & 15,9 & (129) & 22,8 & (143) & \\
\hline$>10$ & 1,1 & (9) & 6,8 & $(42)$ & \\
\hline \multicolumn{6}{|l|}{$\begin{array}{l}\text { inactieve problemen } \\
0\end{array}$} \\
\hline 0 & 25,8 & (209) & 28,6 & $(179)$ & ns \\
\hline 1 & 18,3 & (148) & 15,4 & (96) & \\
\hline $2-5$ & 47,5 & $(385)$ & 41,8 & (261) & \\
\hline $6-10$ & 7,9 & $(63)$ & 12,3 & $(77)$ & \\
\hline$>10$ & 0.5 & $(5)$ & 1,9 & (12) & \\
\hline
\end{tabular}

* inclusief 49 gethnikers gevonden in de controlegroep

solo: geen partner evof alleenstaand

het andal actieve of inactieve problemenregels in de probleemlijst. 
tabel 5. Controlegroephinet-gebrükers (NG). Non-tespons van eerste enquêt wersus nespons in praktijken mat selectie door apothekers. Aantallen, percentages. Verschillen getoetst met Chi-kwadraat en Mamm-Whimey toets. Tabellen exclusief missings.

\begin{tabular}{|c|c|c|c|c|c|}
\hline \multirow[b]{2}{*}{ variabel } & \multicolumn{2}{|c|}{$\begin{array}{l}\text { non-respons enquete } 1 \\
\qquad(n=690)\end{array}$} & \multicolumn{2}{|c|}{$\begin{array}{l}\text { respons enquête } 1 \\
(\mathrm{n}=803)^{*}\end{array}$} & \multirow[b]{2}{*}{$p$} \\
\hline & $\%$ & (n) & $\%$ & (n) & \\
\hline gestacht vrouwelijk & 61,2 & $(401)$ & 66,4 & $(533)$ & 0,041 \\
\hline leeftijd $30-39$ & 15,0 & (98) & 15,6 & (125) & 0,000 \\
\hline $40-49$ & 15,6 & $(102)$ & 22,2 & $(178)$ & \\
\hline $50-59$ & 18,0 & (118) & 18,9 & (152) & \\
\hline $60-69$ & 19,5 & $(128)$ & 25,9 & $(208)$ & \\
\hline$\geq 70$ & 31,9 & $(209)$ & 17,4 & $(140)$ & \\
\hline opleiding laag & 76,2 & $(499)$ & 61,2 & $(482)$ & 0,000 \\
\hline middel & 19,1 & $(125)$ & 30,3 & (239) & \\
\hline hoog & 4,7 & (31) & 8.5 & $(67)$ & \\
\hline verzekering verplicht & 79,4 & $(520)$ & 71,2 & $(563)$ & 0,000 \\
\hline particulier & 20,6 & (1.35) & 28,8 & $(228)$ & \\
\hline solo*w ja & 39,2 & $(257)$ & 26,2 & $(207)$ & 0,000 \\
\hline nee & 60.8 & $(398)$ & 73,8 & $(548)$ & \\
\hline \multicolumn{6}{|l|}{ actieve problemen * } \\
\hline 0 & 29,3 & (192) & 27,3 & (216) & $\mathrm{ms}$ \\
\hline $\mathbb{1}$ & 18,0 & $(118)$ & 22,1 & $(175)$ & \\
\hline $2-5$ & 42,3 & $(277)$ & 42,5 & (336) & \\
\hline $6-10$ & 9.8 & $(64)$ & 7,5 & (59) & \\
\hline$>10$ & 0,6 & (4) & 0,6 & $(5)$ & \\
\hline \multicolumn{6}{|l|}{ inactieve problemen *** } \\
\hline 0 & 33,1 & $(217)$ & 248 & (196) & 0,002 \\
\hline 1 & 22,0 & (144) & 22.8 & $(180)$ & \\
\hline $2-5$ & 38,2 & $(250)$ & 44,6 & (353) & \\
\hline $6-10$ & 6,7 & (44) & 7,2 & $(57)$ & \\
\hline$>10$ & 0,0 & $(0)$ & 0,6 & $(5)$ & \\
\hline
\end{tabular}

* exclusief de personen die op basis van opgave van gebruikte medicamenten achteraf toch gebruiker bleken te zijn ** solo: geen partner en/of alleenstaand *** aantal actieve en inactieve problemregels in de problemlijst 


\section{b) praktijken zónder voorselectie}

De non-respons op de eerste enquête (gebruikers en niet gebruikers samen) bedroeg $40 \%$. De vergeliking van de respondenten met non-respondenten leverde geen verschil in de leeftijds- en geslachtsverdeling op.

De non-respons op de tweede enquêtering.

Dieze analyse werd alleen uitgevoerd in de praktijken met voorselectie en beperkt tot de variabelen leeftijd en geslacht. Tussen respons en non-respons was geen verschil in geslachtsverdeling. In de non-responsgroep kwamen wel meer jongeren (30-39 jaar) voor, terwijl in de groep 50-59 jarigen minder personen te vinden waren ten opzichte van de responsgroep.

\section{Enquẻtering huisartsen over een steekproef van non-responenten}

Van de praktijken met voorselectie door apothekers werd een steekproef van gebruikers nonrespondenten getrokken, waarover de huisartsen geènquêteerdi werden.

Deze steekproef bestond uit 170 vragenlijsten, warvan de huisartsen er 164 ingevuld retourneerden; 6 lijsten betroffen personen die in de praktijken niet meer bekend waren. Deze 164 lijsten betrof het medicamentgebruik van 138 personen (door 20 personen was meer dan 1 psychofarmacon gebruikt in de onderzoeksperiode). De huisarts was bij 20 personen (15\%) niet op de hoogte van het gebruik. Voor zover hem het gebruik bekend was, was in 56\% van de gevallen het voorschrift een herhalingsrecept. De meest gebruikte slaap- en kalmeringsmiddelen waren oxazepam $(26,8 \%)$, temazepam $(23,9 \%)$ en diazepam $(18,1 \%)$; samen vormden ze $68,8 \%$ van het totaal. Van degenen, die het eerste voorschrift in de onderzoeksperiode kregen $(n=46)$ was volgens de huisarts $78 \%$ gestopt, wat betreft de herhalingsrecepten $(n=66)$ was dit 20\%: in total waren 50 van de 118 personen gestopt (van 4 personen was het onbekend). Van degenen die nog gebruikten ( $n=64)$ had hij 29 mensen (45\%) geprobeerd te motiveren om te stoppen. In 6 gevallen kwam het tot een stoppoging.

De klacht(en) waarvoor het medicament gebruikt werd bij de start, indien de start van het medicamentgebruik vòor de onderzoeksperiode lag, waren de huisarts in $44 \%$ van de gevallen niet bekend. Dit was in $13 \%$ van de gevallen bij thet starten van de medicatie tijdens de onderzoeksperiode. De eerste klacht was, voor zover bekend, zowel bij het starten van de medicatie vò̀t als tijdens de onderzoeksperiode in tuim $80 \%$ van de gevallen te vinden in de groep psychische stoornissen (P-tractus van de ICPC). Hierbij kwamen vooral nerveusheid (40$50 \%)$ en slaapproblemen $(30-40 \%)$ voor.

Vergelijken we de steekprof non-respondenten met de respondenten, dan is de top-3 van gebruikte slaap-en kalmeringsmiddelen gelijk (oxazepam, temazepam en diazepam). Bij de andere onderzochte variabelen zijn geen grote verschillen te zien (tabel 6 ) 
abell 6. Huisaurts-enquêtte. Vergelijking wan respondenten met een steekproef uit de non-responglenten. Percentages.

\begin{tabular}{|c|c|c|}
\hline variabele & $\begin{array}{c}\text { respoms } \\
\text { groep } \\
\text { क. }\end{array}$ & $\begin{array}{c}\text { steekproel } \\
\text { nor-respons } \\
\text { of }\end{array}$ \\
\hline arts niet op de hoogte van gebnil & 12 & 15 \\
\hline eerste recept (=start gebruik) in onderzoeksperiode & 46 & 44 \\
\hline klacht onbekend bij start gebruik vốr onderzoeksperiode & 56 & 44 \\
\hline gebrük gestopt & 40 & 42 \\
\hline niet-stoppers gemotiweerd te stoppen & 45 & 45 \\
\hline
\end{tabular}

Tot slot werd parallel aan de hoofdstudie in een viertal praktijken nog een aanvullend onderzoek gedaan naar de visie van de huisarts omtrent de vraag of zij langdurig gebruikers van slaap- en/of kalmeringsmiddelen wel of niet zouden willen benaderen met de bedoeling het stoppen van het gebruik ter sprake te brengen. Uit een computeruitdraai van alle door apothekers afgeleverde benzodiazepinen gedurende drie maanden, werd een steekproef $(n=295)$ genomen van langdurig gebruikers. De huisartsen werd gevraagd een vragenlijst (zie bijlage 5) in te vullen die, naast algemene vragen over het benzodiazepinegebruik en achtegrondvariabelen van patiènt, specifieke vragen bevatte over het onderwerp stoppen/reduceren van het gebruik. De resultaten van deze studie zijn beschreven in hoofdstuk 12 . 


\section{Literatuar}

1) Metsentkers JFW, Hoppenter $P$, Knotmens JA, Kocken RJ, Limonard CBG. Computerized health information in the Netherlands: a registration network of family practices. Brit J Gen Fact $1992 ; 42$ : 102. 6.

2 Metsemakers JFM. Unlocking patient's records in general practice for research, medical education and quality assurance: the Registration Network Family Practices. Dissertatie junil 1994, Rijksuniversiteit Limburg. ISBN $90-5170-279-5$.

3 Lamberts H, Wood M. ICPC International Classification of Primairy Care Oxford university press, New York, $1987.15 \mathrm{BN}$ 0-19.261633-1.

4 Anonymus. ICHPPC-2-defined (inclusion critena for the use of the rubrics of the International Classification of Heath Problems in Primary Care). Oxford University Press, 1983.

5 Vissers FHJA, Knotnerus JA, wan der Gtimten RF, wan der Horst FGEM. Langdurigg gebruik van slaap-en kalmeringsmiddelen in de hutsartspraktijk. Huisarts Wet 1993; 36(12):405-8. Wallace P. Haines A. Use of a questionnatre in general practice to increase the recognition of patients with excessive alcohol consumption. Br Med J 1985; 290; 1949-53.

7 De Jong uhierveld I, Kamphuis $F$. The developpenient of a Rash-type loneliness scale. Applied Psychological Measurement 1985:9:289-99.

8 Anonymus. HSCL, Hopkins Symptom Checklist. In Luteyn F, Hamel L, Bouman T, Kok A. HSCL. Lisse: Swets en Zeitlinger, 1984.

9 Schreurs P. Van de Willige $G$, Tellegen B, Brosschot J. VCL, Utrechtse Coping Lijst. Omgaan met problemen en gebeurtenissen. Handleiding. Vakgroep Klinische Psychologie, Rijksuniversiteit Utrecht 1993.

10 Anonymus. GLLM, Groningse lijst langdurige moeilijkheden. In Ormel J. Het Groningse eertselijnsproject: opzet en aanpak [inten rapport]. Groningen: Rijksuniversiteit Groningen, afdeling Sociale Psychiatrie, 1985.

11 Haes de JCJM. Kwaliteit van lewen wan kankerpatienten. Proefschrift, Rijksuniversiteil Leiden. 1988

12 Andrews FM, Winey SB. Sociall indicators of well-being. Plenum Press, New York. 1976

13 Petri JL. The prescription drug history in pharmacoepidemiology. Dissertatie. Maastricht 1992. ISBN 90 $5278-017-X$

1.4. De Berk HAA. Over het gebruik van benzodiazepinepreparaten in de buisartsenpraktijk. Dissertatije. Nijmegen 1988. ISBN 90-9002477-8

15 Smit T. Rechten en plichten vant privacy-wetgeving. De Huisarts 1993; $9: 72$. 5

16 Peeters-Udding LM. Griepvaccimatie en 'privacy'. Phamaceutisch Weekblad 1993; 3: 175-7 17 Vandenbroucke JP. Strikte nalewing priwacywetgeving remt ontwikkeling genceskunde. Innovator $11994:$

18 Olsthoon-Heim ETM. Viff jatr Wet Persoonsregistraties. Med Contact 1994:49:833-4

19 Norusis MU. SPSS, Professional Statistics. SPSS incorporation. Michighan, Chicago, Ilinois. 1993, release 6.0. ISBN $0.13-178831 \div 0$.

20 Groothede WJHA, Walburg JA. Meetimstrumenten in de versilavingszorg. Gedragstherapie 1985; 18 21 Limbeek van J. Walburg. M. De vroege signalering van alcoholproblematiek. Swets an Zeitlinger b.v.
Lisse. 1987

22 Dingenans: $P$. Geetlings $P$, Limbeek van J, Hinszen D. Diagnostisch Interview Schema. Vertaling en bewerk.ng van NIHM Diagnostic Interwiew Schedule, versie III. Psychiatrisch Centrum AZUA, mei 1981.

23 Haddon C. Women and manquillisers. Sheldon Press, London 1984

24 Helman CO. Tonic, fuel and food; social and symbolic aspects of the long-term use of psychtropic drugs. Social Science and Madicine 1981; 15B:521.533

25 Breukelen van IP. Andlyse van vrigenlijsten =betrouwbaarheid en interne consistenties.. Statistusch Bulletin van de wakgroep methodologie en statistiek van de Rijksuniversiteit limburg. 1995", 2 nim I ISSN:
$0928-9577$ 
hoofdstuk 8

\section{Slaap- en kalmeringsmiddelen}

\section{in de huisartspraktijk:}

gebruikswijze, redenen voor gebruik en kenmerken van gebruikers. 


\section{Abstract}

Objective. To investigate the use of hypnotic and tranquillizing drugs in general practice.

Setting. 9 general practices, members of the RegistratieNet Huisartspraktijken (RNH) of the University of Maastricht (UM)

Method. A sample of 506 patients who use(d) hypnotic and/or tranquillizing drugs and their GP's filled in a post-questionnaire. The patient-users were divided in four categories: shortterm users (once-only and episodic) and long--term users (episodic and continuous)

Results. Taking hypnotic or tranquillizing drugs, one used mostly benzodiazepines. Shortterm users took their drug not longer than 2 months (92\%). The long-term users took in $42 \%$ of the cases their drug continuously. The GP himself or his colleague was the one who mostly started the prescription of these drugs. In all investigated groups were more women than men. In comparison with short-term users the Jong-term users had other social characteristics (higher age, more often single, not working and sick fund insured), other personal characteristics (being more lonely, having other coping styles). Their experience about mental and somatic health was less favourable and the problem-list of their medical record showed more health problems. All users said that health problems (especially musculo-skeletal and circulatory problems) more often than social problems caused complaints for which one was using the drug. There was less change in pattern of use and complaints causing the use in both groups long-term users.

In comparison with short-term use long-term use was associated with older age, more depressive behaviour, a higher score on the medicine addiction index, having problems with children or housing and being satisfied with the drug effects. In comparison with long-term episodic use continuous use was associated with a higher score on the medicine addiction index, older age, lower education, having lost a dear person and a less favourable experience of somatic health.

Conchusion. Dividing users in short-term, long-term episodic and long-term continuous users makes sense. Having health problems is mentioned as an important causal factor in using hypnotic or tranquillizing drugs. Each practice has his group of long term users; this group seems te be still growing. It is important to prevent long-term use in general practice. Doing so, the GP should have skills and opportunities to offer his patient other treatments than farmacotherapy.

Key words. benzodiazepines, general practice, long-term use, short-term use, 


\subsection{Inleilding}

Het gebruik wan slaap- en kalmeringsmiddelen (veelal benzodiazepinen) varieert nogal in de verschillende landen. De prevalentie van het gebruik van deze middelen varieerde in 1984 in de West-Europese landen van $17,6 \%$ (Belgiè) tot $7,4 \%$ (Nederland). De prevalentie van langdurig gebruik in Nederland, gedefinieerd als regelmatig en 12 maanden of langer, was toen $1,7 \%$. In de andere West-Europese landen varieerde deze van $0,3 \%$ tot $5,8 \%$. $^{\prime}$ Uit een populatie-surwey onder de Nederlandse bevolking, uitgevoerd in 1987, bleek 6,9\% van de onderzochten een benzodiazepine gebruikt te hebben. ${ }^{2}$ In 1989 bleek van benzodiazepinegebruikers ongeveer een derde het middel langdurig te gebruiken (dagelijks en langer dan een half jaar). ${ }^{3}$ Onderzoek in 1993 in een Nederlandse duo-praktijk leerde dat 3,1\% van de praktijkpopulatic regelmatig gebruiker was (in een jaar meer dan twee keer een recept voor benzodiazepinen). ${ }^{4}$

Langdurig, regelmatig, chronisch en continu gebruik zijn begrippen die in de literatuur gehanteerd worden voor gebruik van benzodiazepinen voor een langere periode en de mate van gebruik in die periode. Langdurig en chronisch gebruik worden veelal gerelateerd aan een bepaald aantal recepten of een bepaalde hoeveelheid gebruikte medicamenten in een bepaalde periode. Langdurig gebruik omvat echter ook continu gebruik.

Kortdurend gebruik, waaronder eenmalig ('occasionall') gebruik, is de tegenhanger van langdu* rig gebruik. 5 -118

Waar het omslagpunt ligt tussen kort en langdurig gebruik is onduidelijk. Ook is niet duidelijk of de mate van gebruik bij langdurig gebruikers specifieke kenmerken heeft. Een duidelijke en consequente indeling in categorieën van benzodiazepinegebruikers is belangrijk om diverse onderzoeksresultaten te kunnen vergelijken. Eenduidigheid in gehanteerde definities blijkt echter te ontbreken in de literatuur.

Ons uitgangspunt bij dit onderzoek was een empirische indeling. Kortdurend en langdurig gebruik werden onderscheiden met een onderverdeling van beide vormen van gebruik in episodisch dan wel aaneengesloten/dagelijks gebruik.

Doel was na te gaan:

1. in hoeverre deze categorieën van gebruiksvormen in de praktijk voorkomen;

2. of met behulp van deze categorieën een profiel van de patiënt-gebruikers te beschrijwen is. Een dergelijk profiel kan van belang zijn voor huisartsen ter herkenning en preventie van verkeerd gebruik van slaap- en/of kalmeringsmiddelen. 
Bij het zoeken naar dit profiel gingen we na in hoeverre kortdurend en langdurig (episodisch dan wel aaneengesloten) gebruikers zich van elkaar onderscheiden ten aanzien wan demografische kenmerken, gebruikte middelen, wijze wan verstrekking, persoonsgebonden kenmerken, klachten warvoor het middel gebruikt word, gepercipieerde oorzaak van de klacht, afhankelijkheid van het middel, probleemverwerking en gezondheid.

\subsection{Methode}

\section{Algemeen}

Het onderzoek wond plaats in negen huisartspraktijken (2 solopraktijken, 4 associatiepraktijken van 2 of 3 artsen en 3 gezondheidscentra), waarin 28 huisartsen werkzaam waren ten behoeve van een populatie van 48400 ingeschreven patiênten.

Voor het onderzoek werd gebruik gemaakt van een postenquête onder patiẻnten als ook van het onderzoeksbestand van het Registratienet Huisartspraktijken (RNH) van de Universiteit Maastricht (UM). In dit geautomatiseerde bestand zijn naast patiënt-achtergrondgegevens (zoals geslacht, geboortedatum, adres, burgerlijke staat, woonverband, opleiding, verzekeringsvorm) probleemlijsten opgenomen als onderdeel van de medische verslaglegging in de huisartspraktijk. De probleemlijst van een patiënt bevat alle voor de gezondheid relevante problemen en diagnosen, welke langer dan 6 maanden duren, dan wel permanent of recidiverend zijn. De gezondheidsproblemen zijn geregistreerd volgens de International Classification of Primary Care ICPC). ${ }^{19-22}$ Het RNH-bestand wordt door het Medisch en Maatschappelijk Informatie Centrum (MEMIC) beheerd.

De RNH-populatie is vergelijkbastr met de Nederlandse bevolking wat betreft demografische gegevens zoals leeftijd, geslacht, wijze van verzekering, opleiding en woonverband. ${ }^{20}$

\section{Procedure en meetinstrumenten}

Door apothekers werd een overzicht gemaakt van personen van 30 jaar en ouder, die in de periode vanaf 1 oktober 92 tot 1 oktober 93 slaap en/of kalmeringsmiddelen afgehaald hadden. Alleen personen die in het RNH-bestand voorkwamen werden in het onderzoek betrokken. Op basis van de geschatte grootte van de onderzoekspopulatie werd na selectie door de huisartsen (exclusie op praktische gronden zoals taajproblemen, dementie e.d.), aanvankelijk de helft van deze selectie at random schriftelijk benaderd voor deelname aan het onderzoek; bij de eerste beoordeling bleek de respons echter te laag, reden waarom van twee praktijken alsnog de totale selecties benaderd werden met de vraag of ze mee wilden werken aan het enquête-onderzoek. De meegestuurde vragenlijst bevatte vragen omtrent achtergrondgegevens, medicijngebruik in het jaar voorafgaand aan het verzenden van de enquête, gebnuik wan 
genotmiddelen (koffie, tabak en alcohol), ervaren lichamelijk en psychisch welbevinden, als cok de volgende meetinstrumenten: een vragenlijst ter detectie van excessief alcoholgebruik (CAGE-lijst), Eenzaamheidslijst, Hopkinslijst, Copinglijst, Groningse lijst voor langdurige moeilijkheden en een schaal voor kwaliteit van leven. ${ }^{23-29}$

De CAGE-lijst geeft weer of er sprake is van alcoholverslaving. De score van de Eenzaamheidslijst geeft een maat voor eenzaamheid weer en als zodanig voor het ontbreken van sociale steun. De Hopkinslijst meet psychoneurotisch en/of somatisch onwelbevinden. De Copinglijst meet het reageren op stresswolle gebeurtenissen (copinggedrag). De Groningse lijst inventari * seert langdurige moeilijkheden. Deze werd door ons nog aangevuld met drie items: 'moeilijkheden in verband met het verlies van een dierbaar persoon", "moeilijkheden in verband met het verzorgen van een chronisch zieke of een invalide persoon thuis' en 'moeilijkheden in verband met de eigen gezondheid'. Op de schaal voor kwaliteit van leven kan ervaren kwaliteit van leven visueel aangegeven worden.

Na retournering van de eerste vragenlijst, werd aan respondenten die het gebruik van een of meerdere slaap- en/of kalmeringsmiddelen hadden vermeld, een tweede enquête gestuurd met vragen, die betrekking hadden op dat gebruik. Dit gebeurde ook als bleek dat een respondent volgens de gegevens van de apotheek vergeten had een slaap- en/of kalmeringsmiddel te noemen. De tweede vragenlijst bevatte vragen over de aard, omvang en reden van het medicamentgebruik, verdeeld in drie tijdvakken (periode vóór 1 oktober '92, periode van 1 oktober ' 92 tot 1 oktober "93, periode vanaf 1 oktober "93), vragen over satisfactie, bijwerkingen en stoppogingen. Daarnaast bevatte de tweede enquête een medicijnverslavingsindex (MVI). ${ }^{30}$ Deze index is gedeeltelijk opgebouwd uit vragen, die betrekking hebben op drugs- en alcoholmisbruik en de gevolgen daarvan; ${ }^{31-35}$ hij bestaat uit 13 scores en is verdeeld in een viertal dimensies: 'drug-seeking' gedrag, stoppen en ontwenning, voor- en nadelen van gebruik en roes en 'kick'-effect van het middel. De score van deze index is relatief en heeft slechts betrekking op de onderzoekspopulatie. Ter beoordeling van de interne consistentie van de MVI-lijst werd de Crohnbach's alpha $(\alpha)$ bepaald. ${ }^{36}$ De in navolging van De Berk gecorrigeerde index bleek in ons onderzoek een hogere alpha-score te hebben. ${ }^{30}$ Tevens echter had in onze populatie de score omtrent 'tevredenheid over de werking' (onderdeel van de derde dimensie) een sterk negatieve invloed op de $\alpha$, reden waarom we gebruik maakten van een versie zonder dat item ( $\alpha$ 0,71). Deze 'tevredenheid over de werking' werd apart geanalyseerd. De score van de door ons aangepaste verslawingsindex had een variatie van 0-42: hoe hoger de score des te sterker het verslavingsgedrag. 


\section{Dakaverwerking}

Bij die personen, die meer dan één psychofarmacon gebruikt hadden in de onderzoeksperiode, werd het middel dat het langst en/of het meest gebrulkt werd in dat jaar, geselecteerd.

De gebruikers werden verdeeld in twee groepen: kortdurend (maximaal 3 maanden) en langdurig (langer dan 3 maanden) gebruik. In de literauur wordt voor kortdurend gebruik veelal een langere tijdspanne gehanteerd. Evenals Post ${ }^{37}$ in zijn onderzoek, werd door ons de overgang wan kortdurend naar langdurig bij de duur van drie maanden gebruik gelegd. Deze keuze werd mede ingegeven door het advies in de NHG-standaard ${ }^{38}$ een slaapmiddel niet langer dan 2 weken en een kalmeringsmiddel niet langer dan 6-8 weken voor te schrijven. Aan kortdurend gebruik werd eenmalig (én episode/periode) en episodisch (meerdere episodes/periodes) gebruik onderscheiden. De langdurig gebruikers werden onderverdeeld in episodisch en continu gebruikers. De episodes bij kortdurend én langdurig gebruik werden verdeeld in een periode van 1 dag tot 1 week, 1 week tot 1 maand, 1 maand tot 3 maanden en langer dan 3 maanden. Deze verdeling leverde aldus vier categorieèn gebruikers op (figuur $I$ ). De groep kortdurend-eenmalig gebruikers diende als referentie voor de andere groepen, ervan uitgaande dat deze groep het dichtst staat bij niet-gebruikers.

Tot slot werd nog nagegaan in welke mate de gevolgde indeling, gebaseerd op de informatie wan de gebruiker, overeenkwam met de door de apotheken afgeleverde hoeveelheid medicamenten.

\section{Statistische bewerking}

In SPSS $^{39}$ werden de data opgeslagen en bewerkt. De data zijn per groep gepresenteerd door middel van aantallen en/of percentages of gemiddelden. De groepen van langdurig gebruikers (langduriguepisodisch en langdurig-continu) werden vergeleken met kortdurend-eenmalig gebruikers. Bij de bivariate analyses (anialyses per variabele) werd voor nominale schalen de chi-kwadraat toets of de exacte toets van Fisher gebruikt. Voor ordinale schalen de MannWhitney toets. Er werden vier significantie-niveaus (p) onderscheiden: $0,05,0,01,0,005$ en 0,001 .

De groep kortdurend-episodisch gebruikers bleek zeer klein te zijn, slechts 11 personen. Voor deze groep werden geen statistische toetsen gedaan. Presentatie van gegevens van deze groep vindt voor zover van toepassing alleen plats in tabellen.

Door middel van llogistische regressie is nagegaan welke variabelen geassocieerd zijn met de groepsindeling, na correctie voor de andere verklarende variabelen. Langdurig gebruikers zijn vergeleken met kortdurend gebruikers en langdurig-continu gebruikers met langdurig-episodisch gebruikers. Bowendien is door middel van reductie van het model geprobeerd aen zo goed mogelijke voorspelling te maken van langdurig gebruik. 
figuur 1. Opbou onderzoeksbestand. Aantallen, percentages.

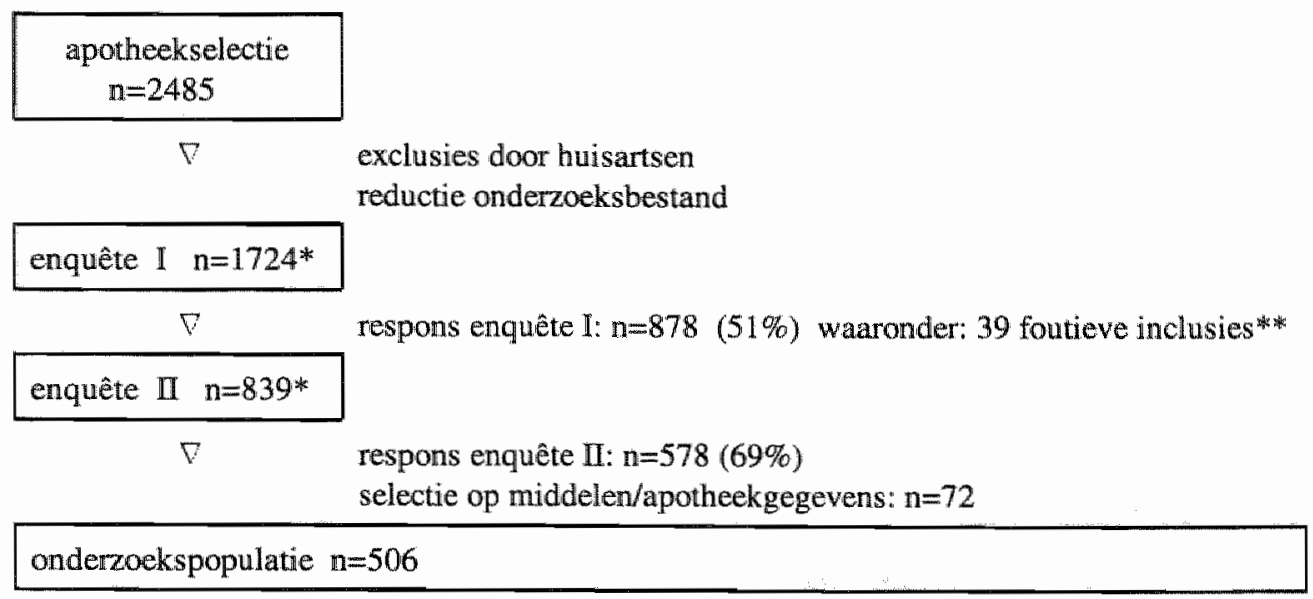

$\nabla$

\begin{tabular}{|c|c|c|c|}
\hline \multicolumn{2}{|c|}{ RORTDURLND GEBRUIK \& 3 mainden } & \multicolumn{2}{|c|}{ IANGDURIG GIBRUIK > 9 maanden } \\
\hline $\begin{array}{l}\text { eenmalig } \\
\text { categorie } 1 \text { - } 1 \text {; }\end{array}$ & $\begin{array}{l}\text { epilodisch } \\
\text { caliegorie } 2\end{array}$ & $\begin{array}{ll}\text { eprisoliseh } & n=239 \\
\text { calegorie } & 3\end{array}$ & $\begin{array}{l}\text { contian. } n=172 \\
\text { categurie } 4\end{array}$ \\
\hline
\end{tabular}

*uitual tijdens onderzoek (enquête I $n=11$, enquête II $n=46$ ):

-verhuisd/utut praktijk

-recall probleem

-middel niet gebruikt/recept voor partner

-gebruik buiten registratieperiode

-door lichamelijke of psychische problemen niket meer in staal mee te doen.

-owerledert

-verkeerde leeftijdselectie

-slechte invulling encumête

aantal
7
2
10
13
3
1
2
15
4

onbekend/missing

\begin{tabular}{|c|c|}
\hline *outieve inclusies $(n=39)$ : & acantall \\
\hline -werkeerd medicament geselecteerd (promethazime, ander psychofarmacon) & 9 \\
\hline -geen psychofamacon te achterhalen in dossier wan patient & 23 \\
\hline -gebruik buiten registratieperiode & 6 \\
\hline verkeerde leeftijdselectie (<30jarar) & 1 \\
\hline
\end{tabular}




\subsection{Resultaten}

\section{De onderzoekspopulatie en respons'}

Van de 2485 door het MEMIC op basis van de apothekersoverzicht geselecteerde patiëntgebruikers werden door de huisartsen 74 personen geẻxcludeerd. Van de resterende 2411 personen werden at random 1724 mensen benaderd om mee te doen aan de postenquête.

De respons op de eerste postenquête was, na een reminder, $51 \%$, Op de vervolgenquête respondeerde (na reminders) 69\%. Bij retoumering van de eerste enquête werd het hierin vermelde medicamentgebruik wergeleken met de apotheekgegevens. Het bleek dat 39 personen foutief geincludeerd waren (verkeerd medicament geselecteerd of het gebruik viel buiten de onderzoeksperiode). De uitval tijdens het onderzoek betrof 57 personen. Voor het onderzoek resteer den tenslotte 506 personen (figuw I).

Bij vergelijking van de non-responsgroep wan de eerste enquête met de respondenten werd geen verschil gevonden in de geslachtsverdeling: wel bevatte de non-responsgroep meer personen die ouder waren dan 70 jaar $(p<0,01)$, meer ziekenfondsverzekerden, laag opgeleiden en meer mensen zonder partner/echtgenoot of echtgenote. Bij de non-respondenten werden meer probleemlijsten aangetroffen waarin geen actieve problemen vookwamen, terwijl in de responsgroep meer lijsten gevonden werden met een grót aantal (meer dan 6) actieve problemen $(p<0,00 \%)$. De non-responsgroep van de tweede enquête toonde evenmin verschil in de geslachtswerdeling; wel was de leeftijdswerdeling anders, er kwamen meer jongeren van 30-39 jaar woor en minder 50-59 jarigen dan bij de respondenten.

\section{De onderzoekspopulatie en het gebruik.}

De onderzockspopulatie werd allereerst beoordeeld naar gebruik: van de 506 personen gebruikte $19 \%$ het middel kortdurend en $81 \%$ langdurig (figuur 1). Door de kortdurend gebruikers (eén of meerdere periodes gebruikt) werd het middel in $75 \%$ van de gevallen 1 maand of korter gebruikt. Bij de langdurig gebruikers (gebruik 3 maanden of langer) waren slechts 5 personen (1\%) die het middel korter dan 6 maanden gebruikt hadden; $12 \%$ gebruikte het middel langer dan 20 jaar (figuur 2). Van de langdurig episodisch gebruikers bleek $27 \%$ van de personen in de onderzoeksperiode gestart te zijn, terwijl $14 \%$ het gebruik stopte tijdens de onderzoeksperiode of in het halve jaar daaropvolgend. Voon de langdurig-continu gebruikers bedroegen deze percentages respectievelijk $18 \%$ en $10 \%$. 
figuur 2. Duur van kondurend en largdurig gebruik. Percentages van beide gebruikersgroepen per maand/jaar gebruik.

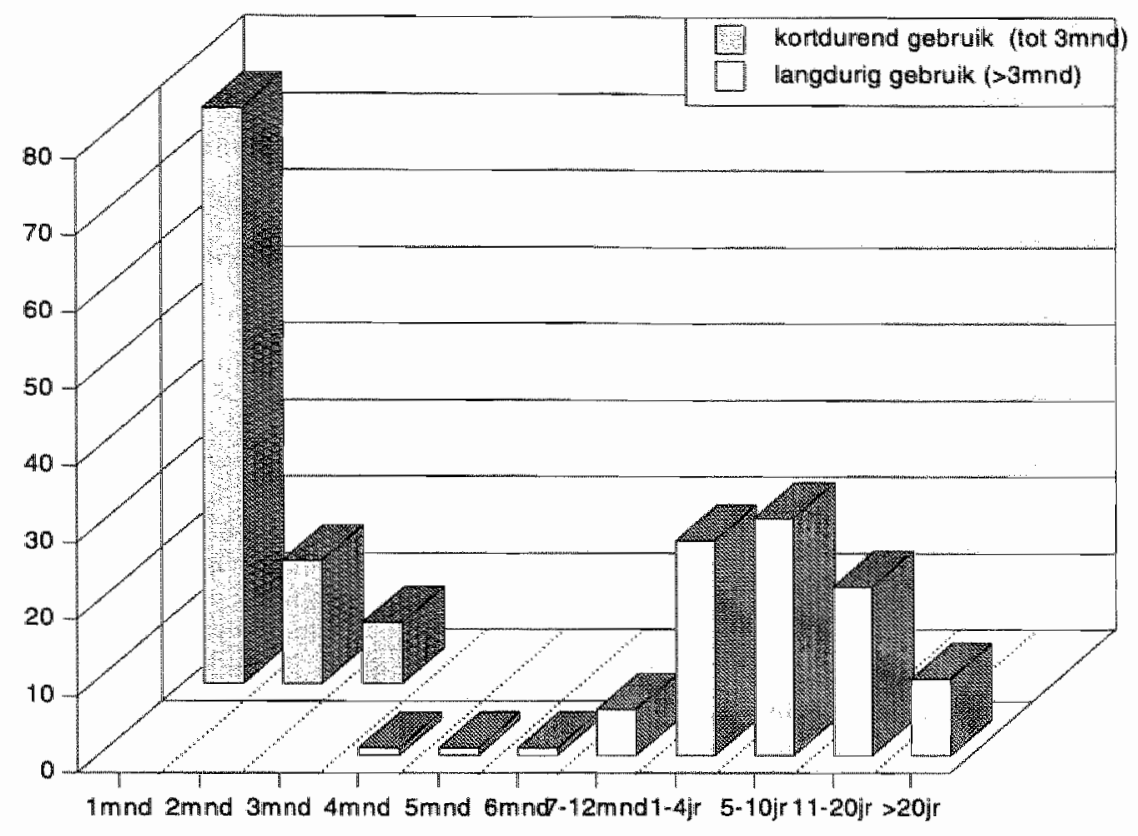

Vervolgens werd de episode van gebruik geanalyseerd. Door de kortdurend-eenmalig gebruikers werd in $55 \%$ van de gevallen aarigegeven dat het medicament én periode van 1 dag tot 1. week gebruikt werd; $25 \%$ gebruikte het én periode van 1 week tot 1 maand en $20 \%$ éen periode langer dan 1 maand maar niet langer dan 3 maanden. Door de langdurig-episodiseb gebruikers werd in $68 \%$ van de gevallen aangegeven dat meerdere episodes van 1 dag tot 1 week gebruikt werd; bij $8 \%$ waren dit episodes van 1 week tot 1 maand en bij $5 \%$ episodes van 1 tot 3 maanden; $10 \%$ meldde perioden die langer waren dan 3 maanden; $9 \%$ gebruikte het middel slechts gedurende één episode in de onderzoeksperiode.

De top-3 van gebruikte middelen was bij kortdurend gebruik: diazeparn, oxazepam en temazepam (respectievelijk $39 \%, 20 \%$ en 19\%); en bij langdurig gebruik: oxazepam, temazepam en diazepam (respectievelijk $30 \%, 20 \%$ en 12\%). Andere middelen dan benzodiazepinen (zoplicon, valeriaan, hydroxyzine, meprobamaat) werden slechts beperkt gebruikt: respectieve$1 i j k 5 \%$ door kortdurend en $4 \%$ door langdurig gebruikers. 


\section{De gebruikersgroepen nader bekeken}

Van de wier cattegorieèn gebruikers bleek de tweede categorie (kortdurend-episodisch) te klein in aantal $(n=11)$ voor aparte analyse en toetsing. Voor de verdere presentatic van gegevens wordt in de tekst de omschrijwing kortdurend gebruiker voor de grcep kortdurend-eenmalig (categorie 1) gereserveerd. De groep langdurig-episodisch gebruikers (categorie 3) wordt episodisch gebruiker genoemd, de groep langdurig-continu gebruikers (categorie 4) continu gebruiker. In de tabellen blijven voor zover van toepassing de vier categorieén vermeld.

Met de kortdurend gebruikers als referentiegroep werden de verschillende categorieèn gebrulkers vergeleken ten aanzien van volgende variabelen;

\section{-Leeftijd, geslacht}

De gemiddelde leeftijd van de kortdurend gebruikers was 47,5 jaar, van de episodisch gebruikers $59,3(p<0,001)$ en van de continu gebruikers 63,6 jaar $(p<0,001)$. In de onderzochte categorieên was ruim $60 \%$ wan de gebruikers van het vrowwelijke geslacht (tabel l).

tabel 1. Geslachtsyerdeling (M/V) in leeftijdsgroepen van de vier categorieün gebruikers $\mathrm{n}=506$ ). Aantallen.

\begin{tabular}{lccccccccc} 
& \multicolumn{2}{c}{ categorie 1} & \multicolumn{2}{c}{ categorie 2} & \multicolumn{2}{c}{ categorie 3} & \multicolumn{2}{c}{ categorie 4* } \\
leeftijdsgroepen & $\mathrm{n}$ & $\mathrm{M} / \mathrm{V}$ & $\mathrm{m}$ & $\mathrm{M} / \mathrm{V}$ & $\mathrm{n}$ & $\mathrm{M} / \mathrm{V}$ & $\mathrm{n}$ & $\mathrm{M} / \mathrm{V}$ \\
\hline $30-39$ jaar & 30 & $10 / 20$ & 3 & $1 / 2$ & 16 & $2 / 14$ & 6 & $4 / 2$ \\
$40-49$ jaar & 21 & $6 / 15$ & 2 & $2 / 0$ & 44 & $18 / 26$ & 23 & $9 / 14$ \\
$50-59$ jaar & 14 & $7 / 7$ & 3 & $2 / 1$ & 56 & $24 / 32$ & 31 & $13 / 18$ \\
$60-69$ jaar & 15 & $5 / 10$ & 2 & $1 / 1$ & 65 & $21 / 44$ & 46 & $16 / 30$ \\
70 jaar en ouder & 4 & $2 / 2$ & 1 & $1 / 0$ & $58^{* * * *}$ & $12 / 46$ & 66 ** & $22 / 44$ \\
\hline totaal & 84 & $30 / 54$ & 11 & $7 / 4$ & 239 & $77 / 162$ & 172 & $64 / 108$ \\
\hline
\end{tabular}

wattegorie $1=$ kordurend enrmalig cantegorie 2 = korturend-episodisch, cattegorie 3 = langdurige episotisch categoric $4=$ langdurig-contimu gebruik * de categorie: 3 en 4 bevatter meer ouderea dan categorie 1, p<0,001

-psychosociale kenmerken en gewoontevorming (tabel 2)

Ten opzichte van de kortdurend gebruikers scoorden de episodisch gebruikers op 9 van de 27 onderzochte variabelen verschillend. Er waren meer alleenstaanden en meer gepensioneerden, minder personen waren nog in het arbeidsproces betrokken; ze scoorden gemiddeld hoger op de eenzaambeidsschaal, bij ervaren problemen reageerden meer personen depressief en uitten hum boosheid minder; meer personen beoordeelden hun lichamelijke gezondheid en functioneren als zijnde van minder kwaliteit en gaven vaker te kennen zich minder gelukkig te voelen. 
tabel 2. Psychosociale kenmerken en gewoontewoming vergeleken voor de 4 categorien getbruikers. Categonie 1 is de referentiegroep. Percentages, gemiddelden. Toetsing van verschillen met chi-kwadravat en Mann-Whitney toets.

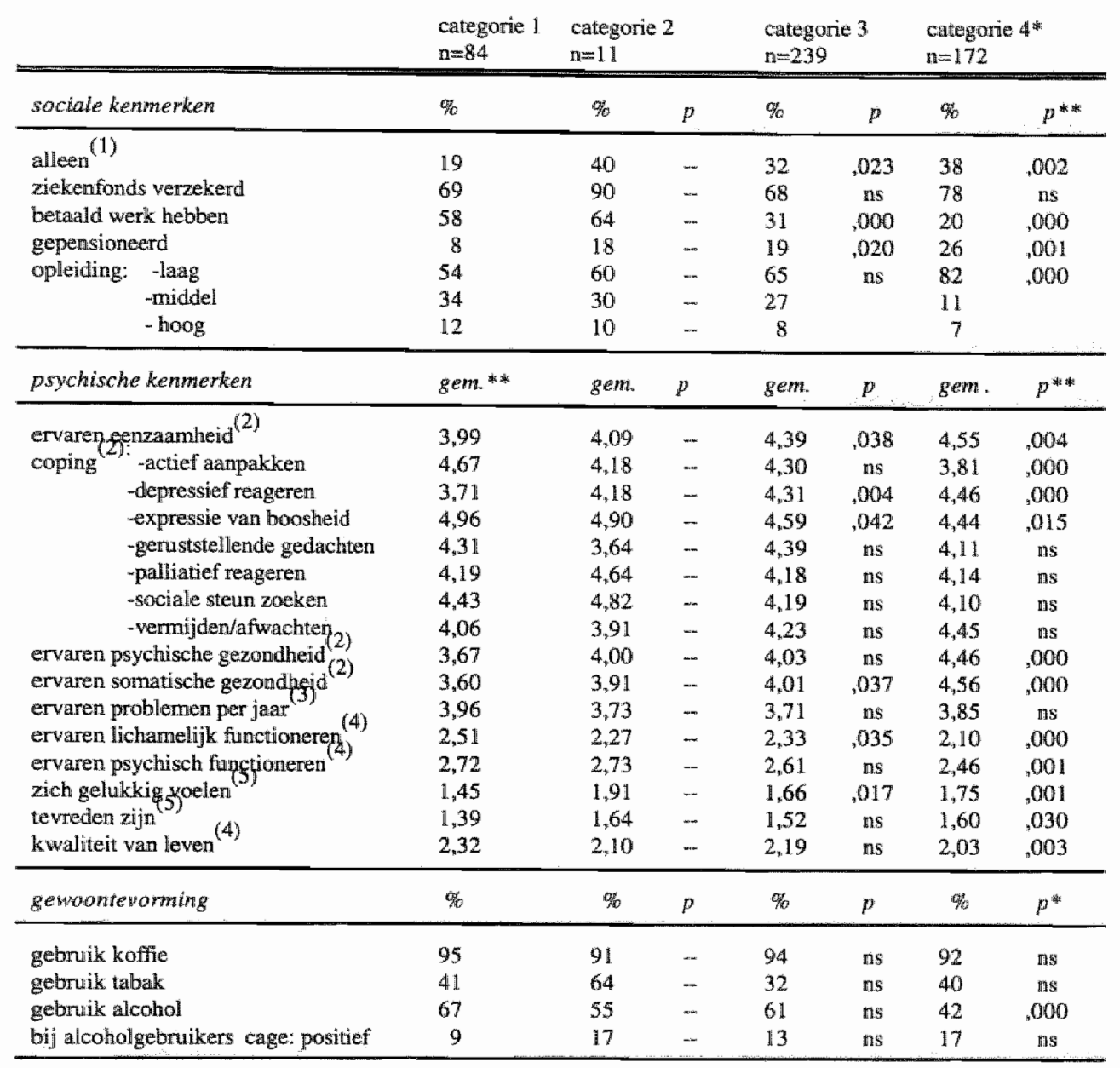

* categorieen gebruikers: categorie $1=$ kortdurand-enmalig categorie $2=k$ ort durend-episodisch categorie $3=$ langdurig-episodisch en categorie $4=$ langdurig - continu

** p-waarde chi-kwadrattoets of Mann-Whitneytoets gem =gemiddeld

(1) alleen: geen partner (meer) hebben en/of alleenstaand zijn

(2) gecategoriseerd in $7 \mathrm{klassem}$ op basis wan cumulatieve percentages: variatie 1.7 , kasse $1=z e e r$ hoog $7=$ zeer laag

(3) wariatie van $0-12$ problemen per jaar

(4) gecategoriseerd in 3 klassen op basis van cumulatiewe percentages: wariatie 1-3, klasse l walag 3 whoog

(5) gecategoriscerd in 3 klassen op basis van cumulatieve pencentages: variatie $1-3$, klasse 1 mhoog $3=1$ aag 
De continu gebruikers scoorden op 17 van de 27 variabelen anders dan de kortdurend gebruikers: er waren meer alleenstaanden en waren minder personen in het arbeidsproces betrokken en meer gepensioneerd; daarbij waren meer personen met een lagere opleiding; ze scoorden gemiddeld hoger op de cenzaambeidsschaal, waren minder actief in hun probleemaanpak, bij ervaren problemen reageerden er meer met depressiviteit en uitten er minder hun boosheid; ze beoordeelden hun psychische en lichamelijke gezondheid minder gunstig, evenals hun lichamelijk en geestelijk functioneren; ze voelden zich minder gelukkig en minder tevreden; hun kwaliteit van leven percipieerden ze lager. Voor zover de episodisch en de continu gebruikers in dezelfde psychische kenmerken verschillend waren ten opzichte van de kortdurend gebruikers, scoorden de continu gebruikers gemiddeld nog hoger/slechter dan de episodisch gebruikers. Er waren bij de continu gebruikers minder personen die alcohol gebruikten dan bij de kortdurend en episodisch gebruikers.

\section{-omvang van de probleemlijsten}

De omvang van de probleemlijst werd vergeleken met betrekking tot de aantallen actieve en inactieve problemen (probleemregels). Het gemiddeld aantal actieve probleemregels bij episodisch en continu gebruikers was groter dan bij kortdusend gebruikers, 4,3 en 5,8 ten opzichte van 3,7 $(p<0,05$ respectievelijk $p<0,001)$. Alleen bij de continu gebruikers kwam een groter aantal inactieve problemen voor (gemiddeld 3,2) dan bij de kortdurend gebruikers (gemiddeld 2,2) $(p<0,05)$. De top-3 van de meest gescoorde problemen (actief en inactief) was voor de episodisch en continu gebruikers hetzelfde: problemen van het bewegingsapparaat, het hart-vaatstelsel en de tractus digestivus. Bij de kortdurend gebruikers was dit het bewegingsapparaat, de luchtwegen en de tractus digestivus.

\section{- receptuerstrekking}

Het eerste recept was voor álle categorieën in het merendeel van de gevallen afgegeven door de huisarts; woor de kortdurend gebruikers was dit in $83 \%$ van de gevallen, voor de episodisch gebruikers $82 \%$, en voor de continu gebruikers $63 \%$. Het eerste recept werd bij de continu gebruikers vaker door een specialist voorgeschreven dan bij de kortdurend gebruikers: $28 \%$ versus $8 \%(p<0,00 \%)$. De langdurig gebrnikers vroegen hun herhalingsrecepten in bijna de helft van de gevallen via de assistente (de episodisch en de continu gebruikers in respectievelijk $42 \%$ en $49 \%$ van de gevallen); voor zover van toepassing voor de kortdurend gebruikers was dit in slechts $6 \%$ van de gevallen zo. 
tabel 3. a) Oorzaken (een of meardere) van de klachu(en) in de periode oktober 92 - 0 ktobert93, genoemd door de wher categorieèn gebruikers. Percentages. Categorie 1 vergeleken met de categorieen 3 en 4 door middel van de chikwadraat toets.

b) Top-5 van de gezondheidsproblemen onderverdeeld in ICPC-hoofdstukken. Percentages

\section{a) Oorzaken}

\begin{tabular}{|c|c|c|c|c|}
\hline & $\begin{array}{l}\text { categoriel } \\
m=84\end{array}$ & $\begin{array}{l}\text { categorie2 } \\
\text { m=11 }\end{array}$ & $\begin{array}{l}\text { categorie } 3 \\
n=239\end{array}$ & $\begin{array}{l}\text { categorie } 4 t \\
m=172\end{array}$ \\
\hline \multicolumn{5}{|l|}{ problemen ap gebied van: } \\
\hline werk/huishouden & 38 & 18 & 31 & 20 \\
\hline school/stendie & 1 & " & 2 & 1 \\
\hline finameiên & 13 & 18 & 15 & 11 \\
\hline hantsvesting & 2 & - & 5 & $11 * *$ \\
\hline Heefsituatie in bunnt of straat & 5 & 9 & 8 & $12 *$ \\
\hline $\operatorname{sex}$ & 8 & 9 & 12 & 10 \\
\hline goodsdienst of geloof & 2 & - & 3 & 3 \\
\hline maatschappelyke ontwikkelingen & 6 & 9 & $\| 1$ & 8 \\
\hline partiner & 2 & 18 & 18 & 15 \\
\hline ouders & 10 & 9 & 8 & 5 \\
\hline kinderen & 7 & 9 & 25 *ark & $20 * * *$ \\
\hline schoonouders & 4 & - & 7 & 4 \\
\hline broers/zussem & 7 & $\ldots$ & 11 & 8 \\
\hline mensen in de buurt & 2 & - & $8 *$ & 6 \\
\hline vrienden/kennissen & 2 & 18 & 4 & 3 \\
\hline contact met anderen & 5 & 9 & $12 *$ & 6 \\
\hline verlies wan dierbaar persoon & 24 & 18 & 21 & $31^{\text {* }}$ \\
\hline verzorging chronisch zieke/mualide thuis & 4 & 9 & 6 & 8 \\
\hline eigen gezondheid & 45 & 55 & $54 *$ & $58 *$ \\
\hline
\end{tabular}

\section{b) Top-5}

pertsonen die gezondheid als oorzaak noemden

nop-5 wan gezondheidsproblemen sescoord in ICPC-mactus:

tractus A (algemeen)

tractus D (maag-darmkanaal)

tractus F (ogen)

tractus $H$ (oren)

tractus $K$ (hait-vaatselsel)

tractus L (bewegingsapparast)

tractus $N$ (zenuwstelsel)

tractus P (psychische stoomissen)

tractus $R$ (uchtwegen)

mactus $T$ (endocrien stelsel)

cumulatief percentage van totaal auntal scores

$\begin{array}{rrrr}8 & - & - & - \\ 16 & 22 & 8 & 8 \\ - & 11 & - & - \\ - & 11 & - & - \\ 17 & - & 17 & 21 \\ 27 & 45 & 29 & 29 \\ - & - & 10 & 9 \\ - & - & 13 & 11 \\ 9 & 11 & - & - \\ - & - & - & - \\ 77 & 100 & 77 & 78\end{array}$

fcalegorie $1=$ kortdurend-enmalig categorie 2 =konturend-episodisch categoric $3=$ langarig categontie $4=$ langdurig-continu gebruik

$* 0<0,05 * p<0,01 * 0<0,005 * 0<0,0001$

opmerking: er waren ook personen die geen oorzaak noemden voor hun klacht: categorie 1: 0, categoric 2 : 1 , categorie 3 : 7 en categorie 4: 9 personen. 
-gebruik van meer middelen.

Gebruik van een tweede s]ap-en/of kalmeringsmiddel in de onderzoeksperiode werd bij de kortdurend gebrutkers in $4 \%$ van de gevallen gemeld, bij de episodisch gebruikers in $9 \%$ en bij de contimu gebruikers in $13 \%$ van de gevallen. Door 1 persoon van de episodisch gebruikers en 2 personen van de continu gebruikers werd zelfs een derde middel gebruikt.

\section{-satisfactie, bijwerkingen en verslaving}

Andere factoren, die onderzocht zijn omdat ze mogelijk een rol zouden kunnen spelen bij geprotaheerd benzodiazepinegebruik zij.jn satisfactie, bijwerkingen en verslavingsgedrag.

-Satisfactie: over de werking van het middel gaf $55 \%$ van de langdurig gebruikers aan zéér tevreden te zijn; bij de kortdurend gebruikers was dit $35 \%(p<0,00 r)$. Ten opzichte van de kortdurend gebruikers waren de langdurig gebruikers gemiddeld meer tevreden over de werking van het middel $(p<0,001)$

-Bijwerkingen: het overgrote deel van de gebruikers in ălle categonieèn meldde geen klachiten te ondervinden ter gevolge van het gebruik (85-100\%).

- Verslavingsgedrag: alleen de continu gebruikers vertoonden volgens de score van de aangepaste medicijnverslavingsindex meer verslavingsgedrag dan de kortdurend gebruikers (MVI-score: 3,0 versus 1,$8 ; p<0,01)$. De gemiddelde MVI-score van de episodisch gebruikers was 2,4 . Vergelijken we de diverse subgroepen (episodes van 1dag-1week, 1week1 maand, 1 maand-3maanden en $>3$ maanden) wan deze groep dan zijn de scores 1,$9 ; 2,8$; 2,5 en 3,3 ; de laatste score tendeert naar verschill ten opzichte van de kortdurend gebruikers $(p=0,065)$

De MVI-score van de episodisch en continu gebruikers vertoonde ten opzichte van elkaar geen verschil. Maar van de drie samenstellende dimensies werd door de continu gebruikers in het 'drug seeking' gedrag hoger gescoord dan door de episodisch gebruikers $(p<0,00 I)$.

\section{-klach en oorzaak van klacht}

-Klacht: in alle categorieèn werd in ongevear driekwart van de gevallen (69-79\%) eén klacht genoemd waarvoor het middel gebruikt werd; $6 \%$ noemde 3 of meer klachten. De eerst vermelde klacht had betrekking op psychische stoornissen, klachten over het bewegingsapparaat en het zenuwstelsel, waarbij de psychische stoormissen veruit in de meerderheid waren $(57-84 \%)$. Ten opzichte van de kortdurend gebruikers vermeldden de langdurig gebruikers meer psychische stoornissen $(p<0,0 /)$ en minder klachten over het bewegingsapparaat $(p<0,01)$. Bij psychische stoornissen werden in álle categorieèn angst/spanning/nervositeit $(37-40 \%)$ en slaapproblemen (44-59\%) het meest genoemd. Indien er méér dan één klacht genoemd werd, betrof dit meestal psychische stoornissen en. klachten van het bewegingsapparaat. 
Bij de episodisch gebruikers was de klacht bij de start van het gebruik in $79 \%$ van de gevallen dezelfde als die in de onderzoeksperiode; bij de continu gebruikers was dit $85 \%$.

-Oorzaak van de klacht (tabel 3): bij het inventariseren van mogelijke oorzaken van de klacht(en) in de periode oktober'92-oktober'93 werden in alle categorieèn gemiddeld 2 à 3 problemen genoemd, het meest met de eigen gezondheid. De episodisch en continu gebruikers gaven dit vaker aan dan de kortdurend gebruikers ( $54 \%$ en $58 \%$ versus $45 \%$ ). Op de vraag wëlke gezondheidsproblemen oorzaak van de klachten waren, werden door alle categorieèn op de eerste plaats problemen van het bewegingsapparaat genoemd en op de tweede plaats problemen van het hart-vaatstelsel. Door de kortdurend gebruikers die gezondheidsproblemen als oorzaak aangegeven hadden, werd in $42 \%$ van de gevallen meer dan één gezondheidsprobleem vermeld, door de episodisch gebruikers in $53 \%$ en door de continu gebruikers in $55 \%$ van de gevallen. Problemen op het gebied van werk/huishouden kwamen bij de kortdurend en de episodisch gebruikers op de tweede plaats als mogelijke oorzaak van de klachten. Bij de contimu gebruikers was dit het verlies van een dierbaar persoon.

Bij de episodisch gebruikers was de oorzaak van de klacht bij de start in $17 \%$ van de gevallen een andere dan tijdens het huidige gebruik, bij de continu gebruikers was dat in $21 \%$ het geval. De top-3 betrof volgens de episodisch gebruikers achtereenvolgens problemen met werk, gezondheid en partner, volgens de continu gebruikers respectievelijk het verlies van een dierbaar persoon, problemen met gezondheid en werk.

\section{- het gebruikspatroon}

Bij de langdurig gebruikers werd gekeken in hoeverre er een verloop te vinden was van episodisch naar continu gebruik in de loop van de tijd. Uitgangspunt was het gebruik in de onderzoeksperiode van oktober ' 92 tot oktober " 93 . De episodisch gebruikers gebruikten in $40 \%$ van de gevallen het middel bij de start dagelijks. Na de onderzoeksperiode veranderde $5 \%$ van hen het episodisch gebruik in dagelijks gebruik. In de groep continu gebruikers is het gebruik bij de start in $94 \%$ van de gevallen dagelijks en is na de onderzoeksperiode in $93 \%$ van de gevallen dagelijks (tabel 4 ).

De informatie die van de gebruikers verkregen werd over hun gebruikswijze, werd vergeleken met de gegevens die de apotheken aangereikt hadden over de aan hen afgeleverde slaap-en kalmeringsmiddelen. In de groep kortdurend gebruikers waren geen verschillen. Bij de episodisch gebruikers waren 4 personen (2\%) die op basis van afgeleverde hoeveel heid medicamenten beschouwd zouden moeten worden als continu gebruiker. Voor de continu gebruikers werd, op basis van het door de patient opgegeven gebruik per dag en het aantal door de apotheek 
afgeleverde eenheden van het medicament, per persoon het percentage gebruiksdagen berekend voor de onderzoeksperiode (een percentage van 90-100\% werd als continu gebruik beschouwd). 60 Personen (35\%) bleken volgens de beschikbare apotheekgegevens cen lager percentage te hebben; $67 \%$ van hen meldde wél dagelijks gebruik ook ná de onderzoeksperiode.

Label 4 Verlowp van gebruilk van slaap-en kalmeringsmiddelen voor langdurig gebruikers (episodisch en continu); uilgangspunt is gebruk in de onderzoeksperiode (oktober'92 oktober93). Aantallen, percentages.

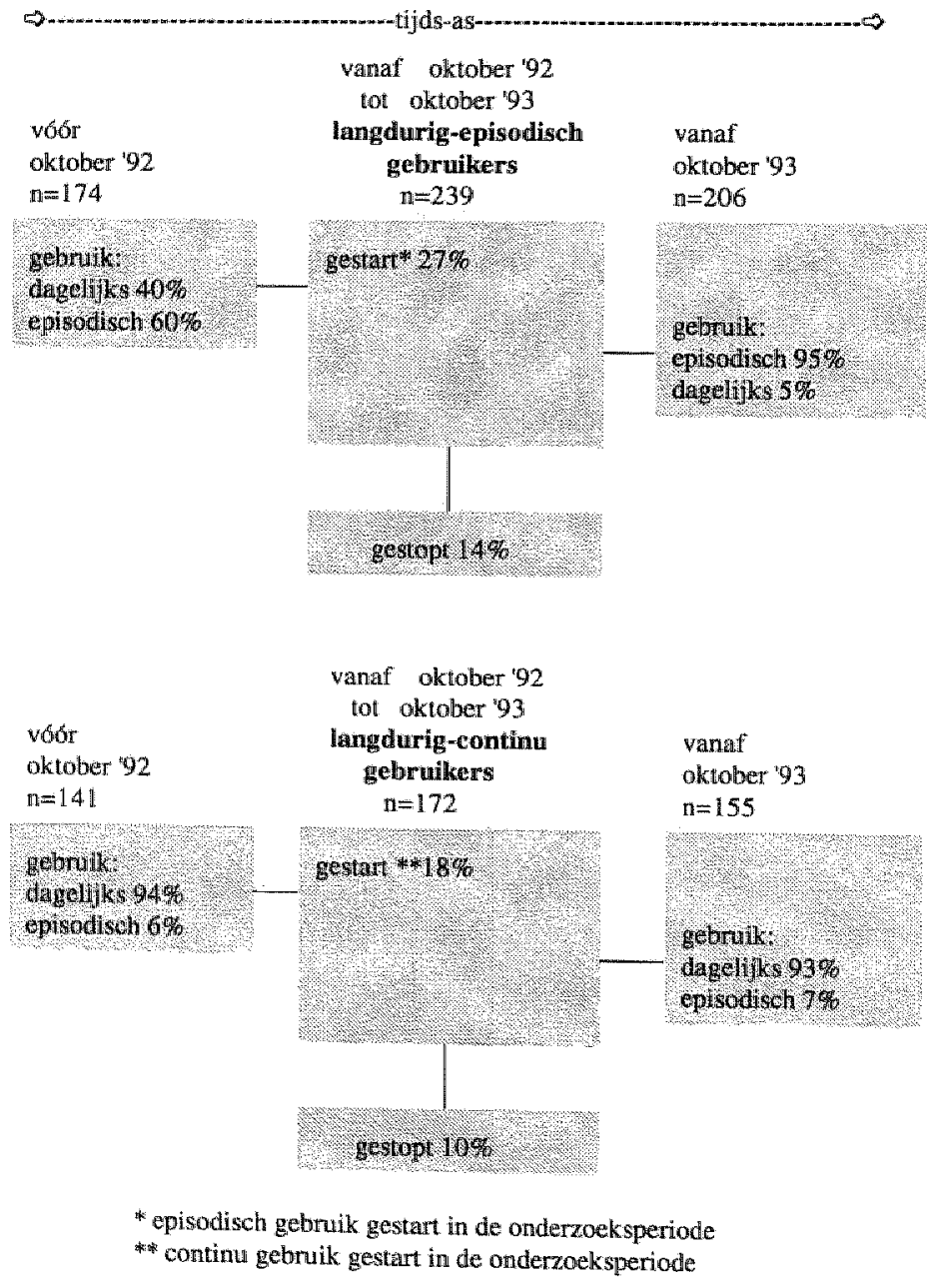




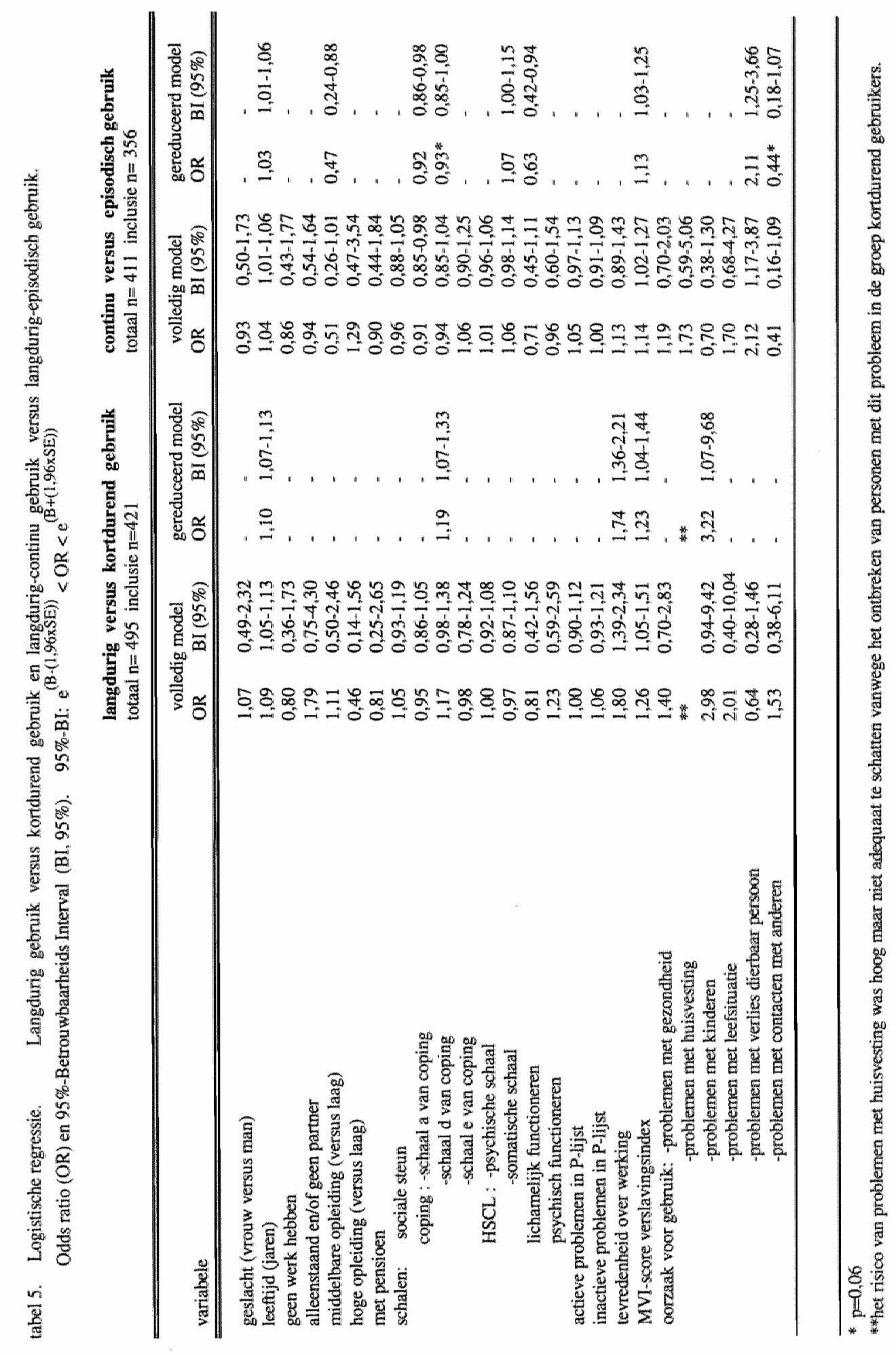




\section{Samenhang wan wariabelen en groepsindeling}

Met behulp van de multipele logistische regressie-analyse werd gezocht naar variabelen die samenhang vertoonden met onze groepsindeling waarbij langdurig gebruik vergeleken werd met kortdurend gebruik en continu met episodisch gebruik (tabel 5). De odds ratio's van de continue variabelen (leeftijd, schalen van copinglijst, schalen van de Hopkinslijst en MVIscore) zijn ter vergelijking met de dichotome variabelen omgerekend voor een verschil van $2 x$ de standaarddeviatie (SD) en zijn in de tekst als OR" vermeld.

De kans om tot de groep langdurig gebruikers te horen werd in het gereduceerd model van de regressie-analyse bepaald door, in aflopende mate, de leeftijd ( $\left.O R^{\prime}=14,5\right)$, een hogere score op de schaal voor depressieve reacties bij ervaren problemen $\left(O R^{\prime}=4,55\right)$, meer tevredenheid over de werking van het middel $\left(O R^{\prime}=3,24\right)$, een hogere $M V I-$ score $\left(O R^{\prime \prime}=3,06\right)$, het hebben van problemen met kinderen ( $O R=3,22$ ) of problemen met huisvesting. Het risico van problemen met huisvesting was niet adequaat te schatten vanwege het ontbreken van personen met dit probleem in de groep kortdurend gebruikers.

Bij de vergelijking van episodisch en contimu gebruikers werd continu gebruik vooral bepaald door een hoge score op de MVI-index $\left(\mathrm{OR}^{\prime}=2,73\right)$, een hoge leeftijd $\left(O \mathrm{R}^{\prime}=2,54\right)$, het werlies van een dierbaar persoon (OR 2,14) en een hoge score op de somatische schaal van de Hopkinslijst $\left(O R^{\prime}=1,97\right)$ als ook slechter oordeel over hun lichamelijk functioneren ( $\left.O R=1,59\right)$, een minder actieve aanpak van problemen $\left(\mathrm{OR}^{\prime}=1,92\right)$. Een lage opleiding had ten opzichte van een middelbare opleiding een OR van 2,13. Bovendien is bij de continu gebruikers een tendens naar een sterker depressief reactiepatroon bij ervaren probleem en naar meer problemen in contacten met anderen.

In de regressie-analyse bleken 6 variabelen woral bij te dragen aan het onderscheid van de groepen kortdurend en langdurig gebruikers: depressief reageren, tevredenheid over de werking van het middel, de MVI-score, het hebben van problemen met de huisvesting of met kinderen, en de leeftijd. De predictiescore uit dit model bleek als "diagnostische test" voor het langdurig gaan gebruiken een Receiver Operating Characteristic (ROC) curve met een area under the curve (AUC) van 0,865 op te leveren. Getracht is de bruikbaarheid van deze test te vergroten door de score te vereenvoudigen, voornamelijk door dichotomiseren van de schalen. Voor de leeftijd werd gekozen woor 10-jaarsklassen. De andere continue variabelen (scores op schalen) werden in twee klassen verdeeld met volgende afkappunten: tevredenheid over de werking met afkappunt een score van 50 (variatie 0-100), de MVI-score met afkappunt bij de score van 2 (variatie 0-42), en de depressie-schaal met afkappunt een score van 12 (variatie 7-28). 
figuur 3. Somscore van de variabelen, onderscheidend voor kortdurend en langdurig gebruik, wergegeven in histogram, ROC-curve en probability-grafiek, waarin de relatie tussen scone en kans op langdurig gebnuik. wordt weergegeven.

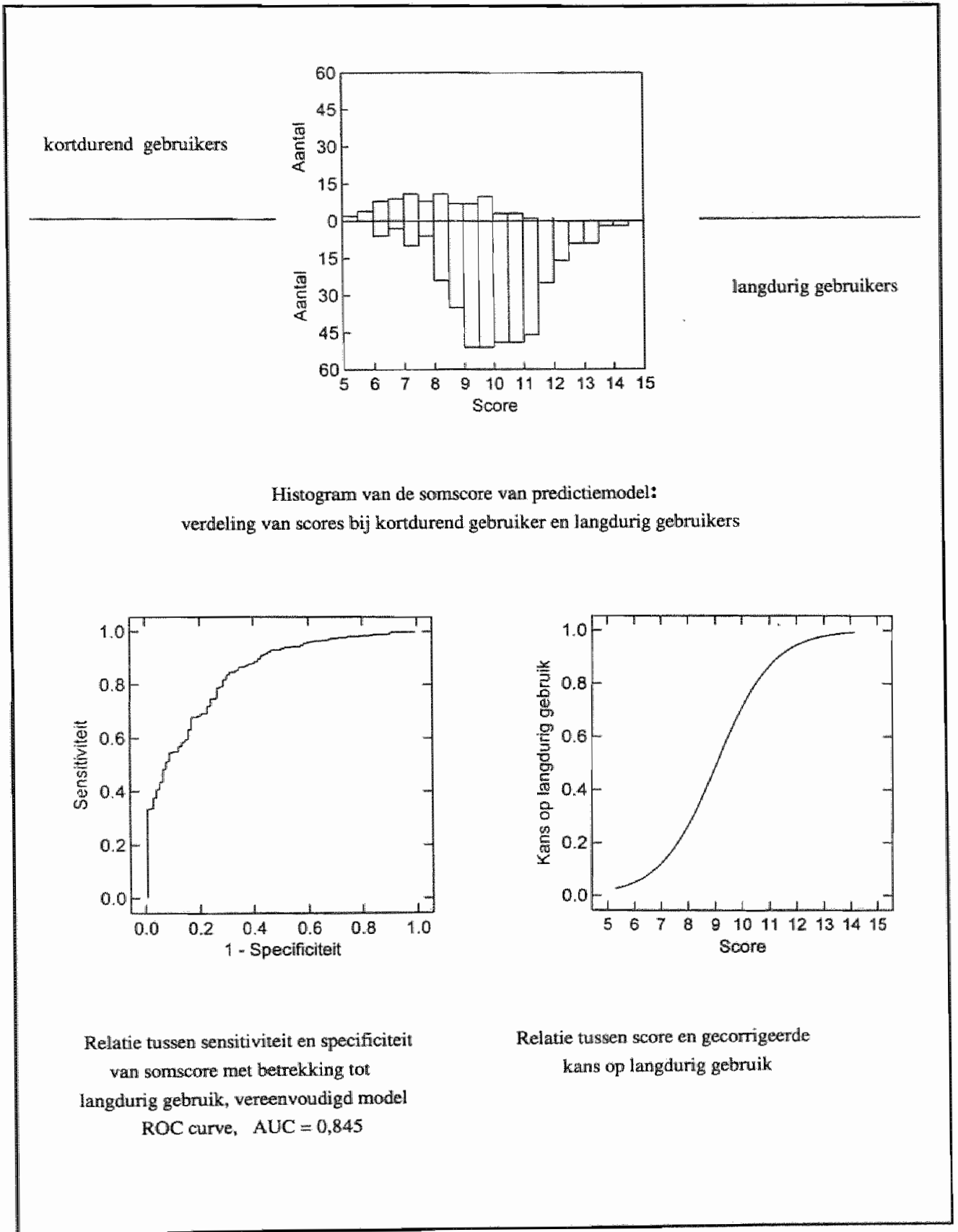


De verenvoudigde score is te berekenen als leeftijd/10 plus één punt voor elk van de volgende scores: tevredenheid over de werking $>50$, het hebben van problemen met huisvesting, het hebben van problemen met kinderen, een score $>12$ op de D-schaal wan de copinglijst en een score $>2$ op de MV1-index.

In figuur 3 zijn een drietal grafische weergaves te vinden omtrent de score van dit predictiemodel. Allereerst is de verdeling van scores van kortdurend en langdurig gebruikers weergegeven in een histogram. Dit laat zien in hoeverre de scores van langdurig gebruikers hoger zijn dan die van de kortdurend gebruikers. Vervolgens is voor elk mogelijk afkappunt van de score de bijbehorende sensiwiteit witgezet tegen 1 minus de specificiteit. Deze ROC curve blijkt een AUC van 0,845 te hebben, slechts een weinig lager dan 0,865 van de originele optimale curve. De vereenvoudiging doet dus nauwelijks iets af aan de voorspellende kracht van de score. Tot slot is ten behoeve van het praktisch gebruik de kans op langdurig gebruik voor elke waarde van de score in een grafiek weergegeven. Hierbij is deze kans bijgesteld op grond van de aantallen patiënten, die het gebruik startten in de onderzoeksperiode.

\subsection{Beschouwing}

In 9 huisartspraktijken werd een steekproef van 506 gebruikers van slaap- en kalmeringsmiddelen onderzocht. De gebruikte middelen bleken voornamelijk benzodiazepinen te zijn. De overgang van kontdurend naar langdurig gebruik gebeurde tussen de 2 en 6 maanden, waarbij kortdurend gebruik in $92 \%$ van de gevallen niet langer dan 2 maanden duurde. Van de langdurig gebruikers gebruikte $42 \%$ het middel continu (=dagelijks). De langdurig gebruikers hadden ten opzichte van de kortdurend gebruikers andere sociale kenmerken en andere persoonlijkheidskenmerken, een minder goede psychische en somatische gezondheidservaring en een langere probleemlijst in het medisch dossier. Alle gebruikers (langdurig gebruikers meer dan kortdurend) noemden vaker een gezondheidsprobleem dan een social probleem als oorzaak van gebruik. De langdurig-continu gebruikers scoorden hoger op een verslavingsindex. Het verschil in de score tussen de beide groepen langdurig gebruikers werd bepaald door drugseeking gedrag. Bij de langdurig gebruikers was weinig verschuiving in het gebruikspatroon, evenmin als in de aard van de klachten. Ten opzichte van kortdurend gebruik waren de volgende variabelen het meest geassocieerd met langdurig gebruik: hogere leeftijd, depressief gedrag, een hoge MVI-score, het hebben van problemen met de kinderen en met de huisvesting, en het tevreden zijn over de werking van het middel; bij de vergelijking van beide categorieën langdurig gebruikers was het continu gebruik vooral geassocieerd met een hogere MVI-score, hogere leeftijd, lage opleiding, het verlies van een dierbaar persoon en een slechtere ervaring van lichamelijke gezondheid. 
Het onderzoek werd verricht met behulp van een steekproef uit de populatie wan een negental praktijken, qua demografische opbouw vergelijkbaar met de nationale bevolking. Informatie van apotheken werd gebruikt woor een wersnelde opsporing van de gebruiker als ook ter reductie van eventuele 'recall bias'. Ook personen die in de eerste enquête vergeten waren het slaapof kalmeringsmiddel te vermelden ( $35 \%$ van de respondenten) werden benaderd voor de vervolgenquête. Het onderzoek richtte zich vooral op de door de patiënt gegeven informatie over zjjn gebruik van slaap- en kalmeringsmiddelen. Het oorspronkelijke voorschrif, dat veelal ook op herhaalreceptuur voorkomt, is vaak niet meer het uitgangspunt van de huidige door de patiënt bepaalde wijze van gebruik. Dit blijkt ook wit het verschil in de informatie van de patiënt over zijn gebruikswijze en die van de apotheek. De follow-up na de onderzoeksperiode is kort (3-6 maanden) zadat een uitspraak over een eventuele verandering van gebruik in de tijd erna van beperkte waarde is. Longitudinale aspecten ten aanzien van gebruik van deze middelen hebben we trachten te onderzoeken door drie meetmomenten te kiezen: de start van de medicatie, de periode '92-'93 en het eindpunt een half jaar later. Daarbij moet worden opgemerkt dat een andere vorm van recall bias wordt gevormd door de tijd-as: naarmate gebeurtenissen verder terug in de tijd hebben plaatsgevonden zal de gegeven informatie hieromtrent mogelijk minder accuraat zijn, hetgeen vooral een rol zal spelen bij langdurig gebruik. Een aantal kenmerken van gebruikers konden we in de enquête slechts écnmaal meten en missen dus het longitudinaal karakter. Dit impliceert een beperking van het predictiemodel, dat gebaseerd is op een cross-sectionele, en niet op follow-up waarnemingen. Het model is echter niet bedoeld ten behoeve van causale interpretaties, maar kan herkenning van langdurig gebruikers ten opzichte van kortdurend gebruikers ondersteumen. Nietternin ligt het voor de hand dat risicofactoren in een cross-sectioneel model ook samenhangen met de kans op het ontwikkelen/onderhouden van langdurig gebruik. Dit dient verder te worden onderzocht in longitudinaal onderzoek.

Door midde] van de vereenvoudigde predictiescore kan de huisarts een indruk krijgen van het risico op langdurig gebruik. Bij de score van 5 of 6 is de kans gering bij een score van 9 is deze $50 \%$ en bij 12 of hoger $90 \%$ of meer. Deze cijfers moeten echter voorzichtig geïnterpreteerd worden. Door het selecteren van de meest onderscheidende variabelen is het onderscheidend vermogen van de score waarschijnlijk te hoog ingeschat. De gelligheid van de predictie berust bovendien op de aamnamen dat er geen substantièle vertekening is opgetreden doon selectie-/recall bias en dat de aantallen van gebruikers die gestart zijn in de onderzoeksperiode de verhouding van de incidenties van kortdurend en langdurig gebruik weerspiegelen.

Gezien de non-respons zal de groep langdurig gebruikers, met name in de categorie ouder dan 70 jaar, in werkelijkheid groter zijn dan door ons gevonden is. 
Als we ervan uitgalan dat kortdurend gebruik dicht staat bij niet-gebruik, kunnen we de onderzoeksresultaten wergelijken met onderzoeksgegevens van studies waarin gebruikers en nietgebruikers vergeleken worden.

Op zoek naar verschillende categorieën gebruikers van slaap- en kalmeringsmiddelen is de tweedeling kortdurend en langdurig gebruik met als afkappunt 3 maanden verdedigbaar gezien de duur van gebruik van beide groepen in onze onderzoekspopulatie. De kleine omvang van het aantal kortdurend-episodisch gebruikers maakt een verdere opdeling in subgroepen van de kortdurend gebruikers weinig zinvol. Het feit dat de langdurig-episodisch gebruikers ten aanzien van verschillende kenmerken dichter bij de kortdurend-eenmalig gebruikers staan, rechtvaardigt een verdeling van langdurig gebruik in twee subgroepen: episodisch en continu gebruik. Hiermee is het verwarrende van het wisselend hanteren van begrippen als langdurig, continu, chronisch en dagelijks gebruik te voorkomen. ${ }^{5-18}$ Resteert wel nog de vraag in hoeverre de gebruikte dagelijkse dosis nog een verdere differentiatie binnen deze groepen te weeg kan birengen...

Ons onderzoek laat zien dat alle vormen van gebruik van slaap- en kalmeringsmiddelen meer bij vrouwen voorkomt. Uit de literatur is reeds bekend dat dit voor langdurig gebruik geldt. $2,6,9,40-42$ De langdurig gebruikers hadden een hogere leeftijd, hetgeen ook in de literatuur beschreven is. $4,8,43-45$ Het is begrijpelijk dat daardoor de kans groter is dat een langdurig gebruiker geen partner (meer) heeft, gepensioneerd en laag opgeleid is. Dit laatste vanwege het feit dat de huidige groep ouderem in hun jeugd minder gelegenheid heeft gehad om te studeren. Het vaker voorkomen van een lage opleiding bij langdurig gebruikers werd reeds in voorgaand onderzoek aangetoond. ${ }^{4,43}$ Vergeleken met kortdurend gebruikers waren bij de langdurig gebruikers voorts meer personen die eenzaam waren, depressief gedrag vertoonden en minder hun boosheid toonden, waarbij de continu gebruikers tevens minder actief hun problemen aanpakten. Dit zijn kenmerken die samenhangen met het hebben van psychische en/of psychiatrische problemen, hetgeen in de literatuur terug te vinden is. $4,5,8,40,41,43$ Alleen de continu gebruikers beoordeelden tevens hun psychisch functioneren vaker slechter. Het gebruik van genotmiddelen verschilde niet in de diverse groepen, met uitzondering van de contimu gebruikers, die zelfs minder alcohol dan de kortdurend gebruikers consumeerden, zoals ook Dunbar wond in zijn onderzoek. ${ }^{46}$ Wellicht neemt in deze groep het gebruik van het benzodiazepine ten clele de functie van het alcoholgebruik over.

De klachten waarvoor de middelen gebruikt werden verschilden weinig, zeker als het gaat om psychische klachten. Slaapproblemen scoorden voor alle drie de groepen het hoogste. We kunnen daarmee de bevindingen van Dumbar niet staven, dat jongeren meer anxiolytica zouden gebruiken en ouderen meer slavapmiddelen. ${ }^{9}$ De aard van de klacht blijkt weinig samenhang te vertonen met de aard van het gebruik. 
Uit ons onderzoek is gebleken dat álle categorieèn gebruikers gezondheidsproblemen het meest noemden als reden voor het gebruik van slaap- en kalmeringsmiddelen. Vergeleken met de kortdurend gebruikers was echter van beide groepen langdurig gebruikers de gezondheid slechter gezien hun kwalificeren en gezien de omvang van de probleemlijst. Dit is analoog aan bevindingen uit andere onderzoeken. $4,6,9,15,40,41,43,45$ Dit zou een verklaring kunnen zijn voor het gegeven dat gebruikers ook via een specialist in aanraking gekomen zijn met benzodiazepinen. Deze redenatie wordt ondersteund door het feit dat ten opzichte van de kortdurend gebruikers van de landurig-continu gebruikers een groter aantal personen meldde dat het eerste recept voor een slaap- of kalmeringsmiddel door de specialist werd uitgeschreven. Dit sluit aan bij het gegeven uit de literatuur dat vaak tijdens opnames in ziekenhuizen het benzodiazepinegebruik gestart wordt. ${ }^{47-50}$ Alle gebruikersgroepen melden echter dat de huisarts in het merendeel van de gevallen het eerste recept verstrekt. Om die reden alleen al is hij degene die het meest in aanmerking komt voor bewaking van de presriptie van deze middelen.

Elke praktijk heeft zijn groep langdurig gebruikers van slaap-en kalmeringsmiddelen. De omvang van deze groep gebruikers groeit ook nu nog steeds. Ook tijdens ons onderzoek startten patiënten nog hun langdurig gebruik.

Een aantal overwegingen op basis van de onderzoeksresultaten kan de voorschrijvend arts behulpzaam zijn bij pogingen het langdurig gebruik wan slaap-en/of kalmeringsmiddelen in zijn praktijk te voorkomen of beperkt te houden.

De huisarts speelt in het merendeel van de gevallen bij de start van het gebruik een rol. Het aandeel van de specialist in de start van langdurig-continu gebruik is echter ook niet onaanzienlijk. Beiden dienen zich van het risico van langdurig gebruik bewust te zijn bij het voorschrijven wan deze middelen. Een goede bewaking is mogelijk als het voorschrift in eén hand te houden is. Een snelle rapportage van de zijde van de specialist dienaangaande en een terugverwijzing naar de huisarts voor eventuele recepten voor slaap-en kalmeringsmiddelen is daartos op zijn plaats. Vooral bij continu gebruikers lijkt het patroon in het merendeel van de gevallen all in de beginfase bepaald. In deze fase is dus waakzaamheid geboden en dient hel verstrekken van recepten zonder arts-patièntcontact niet plaats te vinden.

Door de diverse groepen gebruikers worden vooral psychische stoomissen als klacht gemeld. De klacht zelf kan de voorschrijvend arts weinig steun geven ten aanzien van een risico-inschatting voor langdurig gebruik. Het nagaan van de achterliggende oorzaak voor de klacht is in deze van belang.

Potentiële gebruikers presenteren zich bij hun huisarts en/of specialist veelall met gezondheidsproblemen. Problemen op het gebied van het bewegingsapparaat en/of hart-vaatstelsel kunnen klachten dan wel psychische reacties met zich meebrengen die een opstap zijn naar gebruik van psychofarmaca. Het adequaat behandelen van deze klachten en gepast reageren op de 
psychische reacties kunnen onnodig gebruik van slaap- en/of kalmeringsmiddelen woorkomen. Als patietenten behandeld gaan worden met slaap- of kalmeringsmiddelen zijn de volgende kenmerken van belang om de arts op het spoor te zetten van de kans op langdurig gebruik: een hoge leeftijd van de patiënt, het hebben van problemen met de kinderen of problemen met de huisvesting. Ook als een patiënt-gebruiker om sterkere of meer pillen vraagt, dient de arts alert. te zijn op het begin wan langdurig gebruik. Datzelfde geldt voor tekenen van depressie. Het verstrekken van slaap- en kalmeringsmiddelen tijdens een rouwproces dient met terughoudendheid en gecontroleerd te gebeuren.

Opvallend is dat de nieuwe reeks slaapmiddelen (zogenaamde non-benzodiazepinen) weinig voorgeschreven wordt. In onderzoek blijken ze in ieder geval bij volwassenen jonger dan 65 jaar met chronische insomnia even goed te werken als dle gebruikelijke benzodiazepinen. ${ }^{51}$ Het lijkt in dexe zinvol het advies te volgen van het Nijmeegs formularium, met als achtergrond dat deze middelen een verbetering geven van de slaap zonder verandering van de slaapstructuur en minder risico op rebound insomnia, waarbij wat dit laatste betreft de voorkeur uitgaat naar zolpidem. $^{52}$

Klachten over slaap en angst/nervositeit/gespannenheid kunnen symptomen zijn van diverse vormen van slaapstoomissen en/of psychische stoomissen. Nader onderzoek in dit opzicht is gewenst om duidelijkheid te verschaffen over de indicatie van langdurig gebruik van slaapen/of kalmeringsmiddelen dan wel het toepassen van andere behandelingen. Bij dit alles blijft natuurlijk de vraag in hoeverre de huisarts voldoende geèquipeerd is om de vragen naar slaapen kalmeringsmiddelen te pareren met alternatieven zoals counseling, ontspanningsoefeningen, yoga, slaapcursussen, gedragstherapie en chronotherapie ${ }^{53-55}$ Onderzoek naar deze alternatieven is nog steeds van belang.

Van dagelijks gebruik van slaap-en kalmeringsmiddelen is bekend dat het verslavend werkt. Bij episodisch gebruik is dit niet duidelijk. Theoretisch is het verdedigbaar dat stoppen na een episode gebruik de volgende episode weer tot gevolg kan hebben op basis van ontwenning. Effect van dosis en wijze van gebruik op het risico van verslaving tal nader onderzocht moeten wordem, waarbij rekening gehouden dient te worden met het feit dat informatie van de patiëntgebruiker als ook van de apotheek vaak niet exact genoeg is.

In dit onderzoek werd gebruik gemaakt van de MVI-index een meetinstrument van 10 jaar geleden, hetgeen samengesteld is uit een aantal andere meetinstrumenten. Een ontwikkeling van een eenvoudig eerstelijns instrument voor benzodiazepineverslaving zou een aanwinst voor de huisarts practicus zijn.

Uitbreiding van kennis omtrent de in deze studie gehanteerde groepen gebruikers met hun kenmerken ten opzichte van niet-gebruikers is van belang: hebben ze een slechtere gezondheid? 
Als dat zo is wat is de invloed daarvan op het gebruik? Of is het gebruik van slaap-en kalmeringsmiddelen meer aan de persoonlijkheid gebonden en berust het op het niet goed omgaan met probleemsituaties in het leven?

\section{Dankbetuiging}

Een woord wam dank zijn we verschuldigd aan het Praeventiefonds, dat ons onderzoeksproject "chronisch psychofarmacagebruik in de eerste lijn" (projectnr, 28-2186) financieel ondersteunde. Voor hun inzot bij dit onderzoek gawat onze dank ook uit naar onze research-assistentes Monique Latour en Karit Aretz, evenals de deelnemende ansen en. hun assistentes van gezondheidscentra 'Hoensbroek' te Hoensbroek en 'Withuis" te Venlo, huisartseinpraktijken. Medisch Centrum Putstrat' in Landgraal, 'Voerendaal' in Voerendaal, Kaiser-Veldhuizen in Eygelshoven, Soomers in Kerkrade en Govaert-Leclercq in Stein, huisartspraktijk Guldemond in Ubachsberg en Wan der Ploeg in Kerkrade. 


\section{Literatumir}

1. Balter MB, Manheimer DI, Mellinger GD, Uhlenhuth EH. A cross-national comparison of anti-anxiety/sedative drugs use Curr Med $\mathbb{R}_{\text {es }}$ Opin 1984; 8(suppl 4): 5-20

Van der Waals FW. Sex differences in bencodiazepine use [Dissertatie]. Amsterdam. 1995; 1SBN 90$9008823-7$

3 Herings RMC. Effekten wat chronisch en gecombineerd geneesmiddelengebruik. Utrecht, Universiteit van Uurecht 1989.

Lagro-Jansen $T$, Libenton IJW. Profielen van regelmatige gebruikers van benzodiazepinen in een huisartspraktijk. Ned Tijdswh Geneeskd 1993;137; 1969.73

5. Mellinger $\mathrm{GD}$, Balter MB, Manheimer DI, Cisin IH, Parry HJ. Psychic distress, life crisis and use of psiychotherapeutic medications. Arch Gen Psychiatry 1978; 35: 1045-52.

Mellinger GD, Balter MB, Uhlenmuth EH. Prevalence and correlates of long term regular use of anxiolytics. JAMA $1984: 251: 375-9$

Woods $J H_{4}$ Katz JL, Winger G. Use and abuse of benziodiazepines. JAMA 1988;260; 3476-80

Catalan I, Gath D, et all. General practice patients on long term psychotropic drugs. Br J Psychiatry 1988; 152:399-405

9. Dunbar GC, Perera MH. Jenner FA. Patterns of benzodizzepine use in Great Brittain als measured by gemeral population survey. But J Psychiatry $1989 ; 155: 836-41$.

10 Simpson $\mathbb{R}_{\text {, Power }} K_{\text {, Wallace }} \mathrm{L}$, et all. Controlled comparison of the characteristics of long-term benzodiazepine users in general practice. Br J Gen Pract $1990 ; 40 ; 22+6$

11 King MB, Gabe J, Williams P, Rodrigo EK. Long term use of benzodiazepines: the wiews of patients. Br I Gen Pract $1990_{4} 40: 194-6$

Holm M. One year follow up of users of benzodiazepines in general practice. DMB 1990; 37; 188-91

13 Matalon A, Yimnon A, Hurwitz A. Chronic use of hypnotics in a family practice - patients' reluctance to stop treatment. Fam Pract 1990; 7: 258-60

14. King MB. Is there still a role for benzodiazepines in general practice? Br J Gen Pract 1992; 42:202-5

15 Vissers FHJA, Knotmerus JA, Van der Grinten RF, Van der Horst FGEM. Langdurig gebruik wan slaapen kalmeringsmiddelen in een huisartspraktijk. Huisarts Wet 1993; 36(12): 405-8

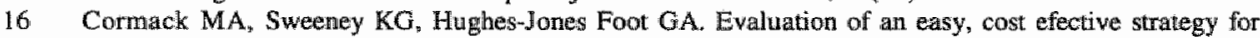
cutting benzodiazepine use in general practice Br J Gen Pract 1994;44:5-8

17 Habraken $H$, Blondeel $L$, Soemen $K$. Is langdurig gebruik van bentodiazepimes zinvol? Huisarts Wet $1994 ; 37(7): 285-8$

18 Bashir K, King M, Ashworth M. Controlled evaluation of brief intervention by general practitioners to reduce chronic use of benzodiazepines. $\mathrm{Br}$ J Gen Pract 1994; 44: 408-12

19 Metsemakers JFM, Höppener P, Knottnerus JA, Kocken RJJ Limonard CBG. Computerized health infornation in the Netherlands" a registration metwork of family practices. Brit J Gen Pract 1992; 42. 1026.

20 Metsemakers JFM. Unlocking patient's records in general practice for research, medical education and quality assurance: the Registration. Network Family Practices. Dissertatie jumi 1994, Rijksuniwersiteit Limburg. ISBN 90-5170-279-5.

21 Lamberts H, Wood M. ICPC, International Classification of Primary Care, Oxford university press, New York, 198\%. 1SBN 0-19-261633-1.

22 Anonymus. ICHPPC-2-tefined (inclusion criteria for the nse of the nubrics of the Intemational Classification of Jealth Problems in Primary Care), Oxford University Press, 1983.

23 Wallace P. Haines A. Use of a questionnaire in general practice to increase the recognition of patients with excessive alleohol consumption. Br Med J 1985;290: 1949 53.

24 De JonguGierveld J, Kamphuis F. The developpement of a Rash-type honeliness scale. Applied Psychological Measumement $1985: 9: 289-99$.

25 Anonymus. HSCL, Hopkins Symptom Checklist. In Luteyn F. Harnel L, Bouman T, Kok A. HSCL. Lisge: Swets en Zeitlinger, 1984.

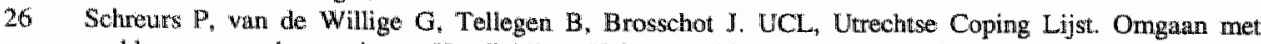
problemen en gebeurtenissen. Handleiding. Vakgroep Klinische Psychologie, Rijksuniversiteit Litrecht, 1993. 
Anonymus. GLLM, Groningse lijst langdurige moeilijkheden. In Ormel J. Het Groningse eeriselijnsproject: opzet en aanpak [intern rapport]. Groningen: Rijksuniversiteit Groningen, afdeling Sociale Psychiatrie, 1985 .

Haes de JCIM. Kwaliteit wan leven van kankerpatiënten. Proefschrift, Rijksuniwersiteit Leiden. 1988 Andrews FM, Witney SB. Social indicators of well-being. Plenuma Press, New York. 1976

Berk de HAA. Over het gebruik van benzodiazepineprepararen in de huisartsenpraktijk [Dissertatie]. Nijmegen 1988. ISBN 90-9002477-8

Groothede WJHA, Walburg JA. Meetinstrumenten in de verslavingszorg. Gedragstherapie 1985: 18 (1):37-46

Limbeek van J, Walburg JA. De vroege signalering van alcoholproblematiek. Swets en Zeitlinger b.v. Lisse. 1987

Dingemans $P$, Geerlings $P$, Limbeek van J, Hinszen D. Diagnostisch Interview Schema. Vertaling en bewerking van NIHM Diagnostic Intertview Schedule, versie IIM. Psychiatrisch Centrum AZUA, mei 1981.

Haddon C. Women and tranquillizers. Sheldon Press, London 1984

Helman CG. Tonic, fuel and food; social and symbolic aspects of the long-term use of psychtropic drugs. Sociall Science and Medicine 1981; 15B: 521-533

Breukelen van JP. Analyse van vragenlijsten =betrou wbaarheid en interne consistentie=. Statistisch Bulletin van de vakgroep meiodologie en statistiek van de Rijksuniversiteit Limburg. 1995; 2 nrl ISSN: $0928-9577$

Post D. Het gebruik van benzodiazepinen in de huisartspraktijk. 1: een onderzoek in eigen huis. Med Contact 1982; 37: 896-9

Anonymus NHG-standaard Slapeloosheid en sllaapmiddelen. Huisarts Wet 1992; 35(5): 212-9

Norusis MJ. SPSS, Profiessional Statistics. SPSS incorporation. Michighan, Chicago, Illinois. 1993, release 6.0 . ISBN 0-13-178831-0.

Wells KB, Kamberg C, et all. Health status, sociodemografic factors and the use of prescribed psychotorpic drugs. Medical Care 1985; 23: 1295-1306

Gene-Badia J, Blay-Pueyo C, Soler-Vila M. Risk factors in the use of benzodiazepines, Iram Pract 1988; 5: $283-8$

Mant $A_{*}$ Mattick RP, de Burgh S, Donelly N, Haal W. Benzodiazepine prescribing in general practice: dispelling some myths. Fam Pract 1995; 12(1): 37-43.

Blijenberg-Ruis B, Garretsen HFL, Schuurnan JH, Verdonk ALT. Het gebruik van staap- en kalmeringsmiddelen. Een secundaire analyse van een Rotterdams onderzoek. T Soc Gezondheidsz 1986; 64: 491-7

Ashton $H$, Golding JF. Tranquillizers: prevalence, predictors and possible consequences. Data from a large United Kingdom survey. Br J Addict 1989; 84: 541-6.

Simpson RJ, Power KG, et all. Controlled comparison of characteristics of long term benzodiazepine users in general practice. Br J Gen Pract 1990; 40:22-6

Dunbar GC, Morgan DD, Perera KMH. The concurrent use of alcohol, cigarettes and caffeine in british benzodiazepine users as measured by a general population survey. Br I Addiction 1988; 83: 689-94.

Edwards CIL, Bushnell $\mathrm{CH}$, Ashton CH, Rawins MD. Hospital prescribing and usage of hypnotics and anxiolytics. Br J Clin Pharmac 1991; 31:190-2

Noble $T$, Spiroulias $M$, White JM. Determinants of benzodiazepine prescribing and administration in a public hospital. Pharmacopsycliat $1993 ; 26 ; 11-4$

Halfens RJG, Lendfers ML, Cox K. Sleep medication in Dutch hospitals. J Adv Nurs 1991; 16:1422-7

Halfens $R_{r}$ Cox $K$, Kuppen-Van Merwijk A. Effect of the use of sleepmedication in Dutch hospitals on the use of sleepmedication at home. J Adv Nurs 1994; 19(1): $55-70$

Nowell PD, Mazumdar S, Buysse DJ, Dew MA, Reynolds CF, Kupfer DJ. Benziodiazepines and Zolpidem for chronic insomnia. A meta-analysis of treatment efficacy. JAMA 1997; 278(24): 2170-7

Anonymus. Formularium Info Nijmegen. 1996; 9 (2): 5-6

Eijkelenboom PR, Knuistingh Neven A. Uitsluipen van chronisch slaapmiddelengebruik. Tijdschi * Hitisartsgeneeskunde 1994; 11(4):303-7

Oosterhuis A. De gedragstherapeutische behandeling van slaapklachten. Huisarts Wet 1995; 38(7):326-7 Smits MG, Nagtegaal JE, Swart ACW. Het symchroniseren wan de biologische klok bif aen versiloord slaap-waakritme. Ned Tijdschr Geneesk 1996; 140(28): 1429 3i 

hoofdstuk 9

\section{Benzodiazepinen:}

\section{de gebruiker en zijn huisarts.}

Bijwerkingen, satisfactie, afhankelijkheid en stoppen gezien door de bril van gebruiker en huisarts.

Dit hoofdstuk is gepubliceerd als:

Vissers FHJA, Jongbloet AJ, Knotmerus JA, Van der Grinten RF, Van der Horst FGEM. Benzodiazepinen: de gebruiker en zijn huisarts. Bijwerkingen, satisfactie, afhankelijkheid en stoppen gezien door de bril wan de gebruiker en zijn huisarts. Huisarts Wet 1998; 41(7): 329. 


\section{Abstract}

Objective. To examine the effects of the use of tranquillizers (benzodiazepines) and the attemps to stop, from the point of view of the users and their GPS

Setting. 9 general practices with 28 GPs, participating in the RegistratieNet Huisartspraktijken (RNH) of the University of Maastricht (UM)

Method. A sample of 506 patients who use tranquillizers and their general practitioners filled in a postal questionnaire. The patient-users were divided in four categories: short-term users (once-only/occasional and episodic) and long-term users (episodic and continuous).

Results. All users reported few side-effects; most GPs reported dependence as a harmful side effect in case of long-term use. Long-term users were more satisfied with their medicine than short-term users, notably the once-only category. Compared with short-term users long-term users rated considerably higher on the medicine-addiction index. Compared with Iong-term episodic users, long-term continuous users scored higher on "drug seeking behaviour". The greater part of the GPs reported that patients who asked for more or stronger benzodiazepines, recieved these. According to the GPs about $50 \%$ of long-term users was motivated by them to stop using; about $25 \%$ of them might have indeed tried to do so. Except the long-term continuous users, all others reported to be able to stop their use without professional help, if they wanted to.

Conclusion. It seems not to be effective to motivate long-term benzodiazepine-users to stop by referring to possible side-effects, because they do not experience them as such. Especially the high satisfaction with benzodiazepines also seems to be a stand in the way.

Key words. benzodiazepines, satisfaction, dependence, family practice. 


\subsection{Inleiding}

Bij het langdurig gebruik van slaap- en kalmeringsmiddelen lijkt de patient vaak degene te zijn die de voortzetting ervan bepaalt: benzodiazepinen worden vaak via herhalingsrecepten zonder arts-patiènt contact verstrekt. ${ }^{1}$

In dat verband rijst de vraag in hoeverre de huisarts op de hoogte is van de aard en het beloop van het benzodiazepinegebruik van zijn patiënten en hoe diens visie hierop is. Daarnaast is de vraag of huisartsen tendensen wan zogenaamd "drug-seeking behawiour" bij hun patiënt nog kunnen herkennen. ${ }^{2}$ Hiermee wordt bedoeld dat de patient geregeld om een hogere dosis medicijnen of een sterker middel vraagt. In hoeverre stemt de arts hiermee in en in welke mate voelt deze zich vrij in het voorschrijven?

De hoge satisfactiegraad bij benzodiazepine-gebruikers, die in sommige studies oploopt tot ruim $90 \%$, zal het stoppen of verminderen van dit gebruik mogelijk verhinderen. ${ }^{3-5}$ Het optreden op lange termijn van lichamelijke afhankelijkheid (bij stoppoging kunnen rebound-en ontwenningsverschijnselen optreden) naast psychische afhankelijkheid en verslaving vormt een ander probleem. ${ }^{6.7}$ Hierdoor wordt gemakkelijk naar het middel teruggegrepen en de stoppoging verijdeld. ${ }^{8-1.0}$

Dat de voorschrijvend huisarts op de hoogte is van de nadelige effecten van benzodiazepinen, de patiënt-gebruiker tevreden is over zijn medicatie en inmiddels een vertrouwde weg heeft on het medicament te verkrijgen, betekent dat er een spanningsveld kan liggen tussen arts en patiënt. Daarom kan het van belang zijn de meningen van patiënten en hun huisartsen met elkaar te vergelijken met betrekking tot aspecten als: het behandelingseffect, bijwerkingen, afhankelijkheid en wenselijkheid van/bereidheid tot stoppen.

Voor het ontwerpen van interventies om reductie of stoppen te bewerkstelligen bij langdurig benzodiazepine-gebruik is het nuttig meer inzicht te krijgen in factoren die een rol spelen bij stoppogingen (op advies van de huisarts of op eigen initiatief).

Benzodiazepine-gebruikers kunnen niet als een homogene groep beschouwd worden wat betreft het innamepatroon. Immers iemand die het middel cenmalig-kortdurend inneemt is een heel ander soort gebruiker dan de persoon die dit al jaren dagelijks doet. In dit onderzoek is daarom uitgegaan van een indeling in gebruikersgroepen "kortdurend" (eenmalig of episodisch) en "langdurig" (episodisch of continu). 
Er is gezocht naar een antwoord op de wolgende vragen:

* In hoeverre worden door de gebruikers zelf en/of door hun huisartsen ongewenste neveneffecten van het mildel aangegeven?

* In hoeverre zijn gebruikers tevreden over de werking van het slaap- en/of kalmeringsmiddel? Wat is de mening van de betreffende huisartsen ten aanzien van het behandelingseffect?

* In hoeverre zijn gebruikers afhankelijk van het middel en zijn er tendensen van het zogenaamde "clrug-seeking behaviour" watneembaar"?

* In hoeverre is er behoefte of bereidheid van gebruikers en/of artsen orm het gebruik van het middel te minderen of ermee te stoppen? Zijn de gebruikers naar eigen zeggen en naar het oordeel van de huisarts door hun arts ooit gemotiveerd te stoppen, alvorens ze pogingen tot stoppen ondernomen hebben? Stoppen ze dan ook, met of zonder deskundige hulp?

\subsection{Methode}

Deze studie vormt een onderdeel van een onderzoek dat plaats vond in negen huisartspraktijken in Zuid-Limburg, waar 28 huisartsen werkzaam waren. Het betrof verschillende vormen van praktijken (solo- en associatiepraktijken en gezondheidscentra), die alle zijn aangesloten bij het RegistratieNet Huisartspraktijken (RNH) van de Universiteit Maastricht (UM). ${ }^{11}$ Dit geautomatiseerde bestand, beheerd door het Medisch en Maatschappelijk Informatie Centrum (MEMIC) bevat onder andere patiënt-achtergrondgegevens, die in dit onderzoek gebruikt zijn. Apothekers makten woor deze praktijken een overzicht van patiënten van 30 jaar en ouder, die in de periode vanaf 1 oktober " 92 tot 1 oktober " 93 slaap-en/of kalmeringsmiddelen hadden afgehaald ( $\mathrm{n}=2485$ ). Op basis wan de geschatte grootte van de onderzoekspopulatie werd na selectie door de huisartsen (exclusie op praktische gronden zoals taalproblemen , dementie e.d.), aanvankelijk de helft wan deze selectie at random schriftelijk benaderd voor deelname aan het onderzoek; bij de eerste beoordeling bleek de respons echter te laag, reden waarom van twee praktijken alsnog de totale selecties benaderd werden met de vrasig of ze mee wilden werken aan het enquête-onderzoek $(n=1724)$.

De enquête onvatte onder meer vragen omtrent medicatiegebruik gedurende het afgelopen jaar en ervaren lichamelijk en psychisch welbevinden. Aan de respondenten werd een tweede enquête gestuurd. Deze vervolg-vragenlijst ging in op aard en omvang van het gebruik van het slaap-en/of kalmeringsmiddel, de satisfactie, eventueel ervaren bijwerkingen en stoppogingen met de afloop hiervan. Bovendien bevatte deze enquête een gecorrigeerde medicijnverslavings- 
index (MVI) met als doel een indruk te krijgen over de mate van medicijnverslavingsgedrag. 10 Deze geconigeerde index is opgebouwd uit vier dimensies: 1) vragen omtrent drug-seeking gedrag, 2) voor- en nadelen van het gebruik, 3) stoppen en ontwenning en 4) het roes- en kickeffect van het middel. Ter beoordeling van de interne consistentie van de voor de index bestemde vragenreeks werd Crohnbach's alpha bepaald: deze bedroeg 0,53. De subscone "tevredenheid over de werking" uit de tweede dimensie had een sterk negatieve invloed op de alpha; door dit item weg te laten steeg de alpha naar 0,71 . We gebruikten voor het onderzoek daarom deze aangepaste versie. De subscore "tevredenheid over de werking" werd apart als variabele geanalyseerd.

De score van de MVI-index had een variatie van 0 tot 42. Deze waarden zijn relatief en hebben slechts betrekking op de onderzochte patiënten-popullatie: hoe hoger de score, hoe sterker het verslavingsgedrag.

De gebruikers werden gesplitst in twee groepen: kortdurend gebruik (korter dan 3 maanden) en langdurig gebruik ( 3 maanden of langer). Vervolgens werd in beide groepen nogmaals een onderverdeling gemaakt: de kortdurend gebruikers werden verdee]d in eenmalig gebruikers (één episode) en episodisch gebruikers (meerdere episodes) en de langdurig gebruikers in episodisch en continu gebruikers. Deze vier groepen gebruikers werden onderling vergeleken, waarbij de groep van de kortdurend-eenmalig gebruikers als refierentiepunt diende, zijnde de groep die het meest de niet-gebruiker benadert.

Na enquêtering van de patiënten werd aan de betreffende huisarts een artsenvragenlijst gezonden, die enerzijds bestond uit vragen die ook in de patiêntenlijst aan bod kwamen, anderzijds uit specifieke vragen omtrent prescriptiegedrag, dosisaanpassingen en de bijdrage aan eventuele stoppogingen.

De antwoonden uit de enquêtes werden bewerkt en geanalyseerd met behulp van het softwareprogramma Statistical Package for the Social Sciences (SPSS). ${ }^{12}$

Bij de analyse werd gebruik gemagkt van de chi-kwadraat-test, de student-T-test en de MannWhitney-U-test. De gevonden verschillen werden statistisch significant geacht bij $\mathrm{p} \leq 0,05$. Indien het aantal waarnemingen zeer gering was, zijn geen toetsresultaten gepresenteerd; dit betrof vooral de groep kortdurend-episodisch gebruikers $(n=11)$.

\subsection{Resultaten}

\section{Onderzoekspopulatie}

Het responspercentage van de eerste enquête lag op $51 \%$. Vergelijken we de uiteindellijk in het onderzoek opgenomen gebruikers-respondenten met de non-respondenten van de eerste enquête, dan blijkt dat de non-responsgroep niet verschillt qua geslachtsverdeling, maar wel 
minder mensen in de leeftijd van 50-70 jaar en meer ouderen ( $>70$ jaar) bevat en (daarmee gecorreleerd) meer laag-opgeleiden, meer ziekenfondsverzekerden en meer mensen die geen partner hebben en/of alleenstaand zijn. Op de vervolgenquête betreffende het specifieke slaapof kalmeringsmiddel reageerde $69 \%$.

tabel 1 De onderzoekspopulatie ( $\mathrm{n}=506$ ) onderscheiden in wer groepen gebruikers. Geslacht, gemiddelde leeftijd. Aantaillen.

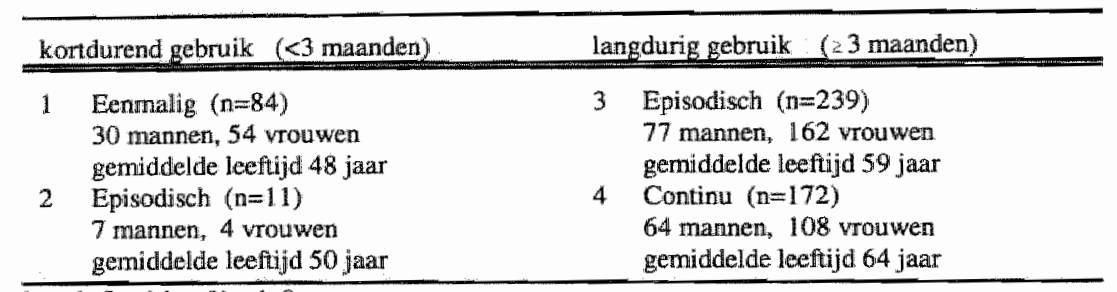

aic ook fig. 1 hoofdstuk 8

De verdeling over de vier groepen gebruikers is in tabel 1 weergegeven. Er waren 95 kortdurend gebruikers (18\%) en 411 langdurig gebruikers $(82 \%)$. Er was geen verschil in de geslachtsverdeling tussen de kortdurend en langdurig gebruikers. Beide groepen langdurig gebruikers bleken ouder te zijn dan de korturend-eenmalig gebruikers $(p<0,001)$. De gebruikte middelen waren alle, op $1 \%$ na, benzodiazepinen.

\section{Huisartsen.}

Bij analyse van de gegevens uil de artsenvragenlijst bleek dat in $88 \%$ van de gevallen de huisartsen op de hoogte waren van het benzodiazepinegebruik van hun patiẻnten, vaker bij langdurig gebruikers (91\%) dan bij eenmalig gebruikers (78\%). In geval van een herhalingsrecept (langdurig gebruik) bleken de eigen huisartsen aan in $32 \%$ wan de gevallen zelf het eerste voorschrift afgegeven te hebben. Anderen, die het recept voor de eerste keer uitschreven, waren onder andere collega-huisartsen $(47 \%)$ en specialisten $(11 \%)$, bij $10 \%$ was dit onbekend.

Van langdurig gebruikers was het de huisartsen in $56 \%$ van de gevallen onbekend voor welke klacht het middel bij de start voorgeschreven werd. Gevraagd naar de klacht waarvoor de medicatie tijdens de onderzoeksperiode werd voorgeschreven, wisten zij deze veelal wel te benoemen. Benzodiazepinen bleken vooral te worden voorgeschreven voor "slapeloosheid" $(44 \%)$ en "gevoelens van nervositeit en gespannenheid" (31\%). 


\section{Bijwerkingen}

Door de gebruikers werden in het algemeen weinig ongewenste neveneffecten van het benzodiazepine-gebruik opgegeven; $88 \%$ zei geen bijwerkingen ervaren te hebben, waarbij er geen verschil was tussen de diverse groepen gebruikers. Uit de antwoorden op een open vraag naar bijwerkingen bleek dat deze bestaan uit "slaperigheid", "duizeligheid" en "concentratiestoornissen" en "lichamelijke klachten", voomamelijk hoofdpijn en klachten van gastrointestinale aard. Praktisch nooit werd door de gebruikers "afhankelijkheid en gewenning" aangegeven.

Voorzover bij de huisartsen bekend (drie kwart van de onderzoekspopulatie) meldden ze bij kortdurend-eenmalig gebruikers in $10 \%$ van de gevallen bijwerkingen; bij de langdurigepisodisch gebruikers was dit $9 \%$ en bij de langdurig-continu gebraikers $27 \%$. $(p<0,00 l)$ Verder gaven de huisartsen aan dat de aard van deze bijwerkingen bij de continu gebruikers in $21 \%$ van de gevallen bestond uit "sufheid, moeheid en slaperigheid"; veruit het grootste aanta] ongewenste neveneffecten was volgens hen echter "afhankelijkheid en gewenning" (70\%).

\section{Tevredenheid}

Op een 5-puntschaal gaf 35\% van de kortdurend-eenmalig gebruikers aan "zeer tewreden" en $16 \%$ "zeer ontevreden" te zijn over de werking van hun benzodiazepine, de langdurig-episodisch gebruikers $54 \%$ respectievelijk $3 \%$ en de langdurig-continu gebruikers $56 \%$ respectievelijk 4\%. De langdurig gebruikers scoonden gemiddeld hoger ten aanzien van tevredenheid dan de eenmalig gebruikers. $(p<0,001)$

Bij de kortdurend-eenmalig gebruikers beoordeelden huisartsen het behandeleffect op de klachten in $52 \%$ van de gevallen als "goed tot zeer goed"tegen $53 \%$ en $43 \%$ bij de twee groepen langdurig gebruikers. Voor de kwalificatie "slecht tot zeer slecht" gold dat in $3 \%$ respectievelijk $5 \%$ en $11 \%$ van de gevallen.

\section{Aftankelijkheid}

De gemiddelde score op de medicijnverslavingsindex (MVI) bedroeg 1,8 voor de kortdurendeenmalig gebnikers, terwijl de langdurig-episodisch gebruikers 2,4 en de langdurig-continu gebruikers 3,0 scoorden; tussen kortdurend-eenmalig en langdurig-continu gebruikers was het verschil significant $(P<0,0)$. Bij vergelijking van de twee groepen langdurig gebruikers ten aanzien van de samenstellende dimensies van de verslavingsindex, bleek alleen de dimensie van "drug-seeking behaviour" te verschillen: de continu gebruikers scoorden daarin hoger $(P<0,001)$. Op de vraag naar ervaren afhankelijkheid van het middel werd door de kortdurendeenmalig gebruikers in $89 \%$ van de gevallen ontkennend geantwoord, door de langdurigepisodisch gebruikers in $59 \%$ en de langdurig-continu gebruikers in $24 \%$ van de gevallen. 
De mate van verslaving is in de artsenlijst vertaald naar vragen met betrekking tot "drugsecking behaviour". Huisartsen gaven aan dat $2 \%$ van de kortdurend-eenmalig gebruikers wel eens om een hogere dosis van het middel vroeg, wan de langdurig-episodisch gebruikers $20 \%$ en van de continu gebruikers $27 \%$. Desgevraagd gaven de huisartsen aan bij langdurig gebruikers in $14 \%$ wan de gevallen "nooit" met extra medicatie in te stemmen en in $20 \%$ "vaak". Het vragen naar andere/sterkere middelen gebeurde volgens de huisartsen bij de kortdurend-eenmalig gebruikers in $5 \%$ en bij de langdurig gebruikers in $18 \%$ van de gevallen. Aan dit verzoek van de langdurig gebruikers zei $17 \%$ van de huisartsen "nooit" en $45 \%$ "niet vaak" toe te geven. Op de vraag of de huisarts zich wrij in diens wijze van voorschrijven voelde, betitelden de huisartsen bij de kortdurend-eenmalig gebruikers zich in $68 \%$ van de gevallen "volledig vrij", en bij de langdurig gebruikers in $35 \%$ van de gevallen. $(p<0,001)$

\section{Stoppen}

Van de langdurig gebruikers gaf $12 \%$ aan het middel niet meer te nemen; hiervan gaf $37 \%$ aan dit zonder hulp bereikt te hebben en $25 \%$ dat de huisarts daarbij geholpen had. Eén op de 5 stoppers van de groep langdurig gebruikers gaf aan dat "angst voor een verslaving" de belangrijkste reden voor het stoppen was. Van de niet gestopte langdurig gebruikers gaf $71 \%$ aan nooit het gevoel te hebben gehad het gebruik te moeten minderen of stoppen. Als dit wel zo was, werd het in ongeveer $70 \%$ van de gevallen bij de huisarts bespraken. In de groep langdurig-episodisch gebruikers verwachtte $79 \%$ zonder hulp te kunnen stoppen, terwij $29 \%$ van de continu gebruikers dit op eigen houtje dacht te kunnen volbrengen. Als meest geschikte persoon bij het begeleiden van een stoppoging werd door beide groepen in $54 \%$ van de gevallen de "huisarts" genoemd.

Tabel 2. Het stoppen van gebrulk in de vier groepen gebruikers, perceptie van de huisarts. Percentages per groep, mathutlen.

\begin{tabular}{|c|c|c|c|c|c|c|c|c|}
\hline \multicolumn{4}{|c|}{ initiatiefinemer } & \multicolumn{5}{|c|}{ wijze van stoppen } \\
\hline $\begin{array}{l}\text { stoppers in } \\
\text { gebrutikers- } \\
\text { groepen }\end{array}$ & $\begin{array}{c}\text { advies } \\
\text { hunkarts } \\
\%(\mathrm{~m})\end{array}$ & 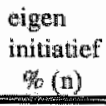 & $\begin{array}{l}\text { anders } \\
\%(n)\end{array}$ & $\%(\mathrm{n})$ & $\begin{array}{c}\text { op eigen } \\
\text { houtje } \\
\%(\mathrm{~m})\end{array}$ & $\begin{array}{l}\text { sohemut } \\
\text { huisarts } \\
\text { cyo (n) }\end{array}$ & $\begin{array}{l}\text { anders } \\
\%(n)\end{array}$ & $\begin{array}{l}\text { onthekend } \\
\%(\mathrm{n})\end{array}$ \\
\hline groep 1 - & $47(25)$ & $40(21)$ & $13(7)$ & $51(27)$ & $17(9)$ & $17(9)$ & $2(1)$ & $13(7)$ \\
\hline groep 2 & 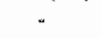 & $86(6)$ & $14(1)$ & $29(2)$ & $43(3)$ & - & $14(1)$ & $14(1)$ \\
\hline groep $3 *$ & $25(21)$ & $54(45)$ & $21(17)$ & $29(24)$ & $31(25)$ & $7(6)$ & $4(3)$ & $29(24) *$ \\
\hline groep $4 *$ & $37(6)$ & $44(7)$ & $19(3)$ & $19(3)$ & $25(4)$ & $6(1)$ & $19(3)$ & $31(5)$ \\
\hline
\end{tabular}

* groep 1- stoppers van koridurend-eenmalig gebruikers groep $2=$ stoppers van kortdurend episodisch gebruikers groep $3=$ stoppers van langdurig-episodisch gebruikers groep $4=$ stoppers van langdurig-continu gebruikers

* missing: 1 
Uit de huisartsenquete kon worden afgeleid dat volgens de huisartsen, voor zover het gebruik hem bekend was, $83(41 \%)$ van de langdurig-episodisch gebruikers gestopt zouden zijn en 16 $(10 \%)$ van de langdurig-continu gebruikers; van de kortdurend-eenmalig en kortdurend-episodisch gebruikers zouden 6 respectievelijk 2 personen niet gestopt zijn. Volgens de huisartsen had van de stoppers in de groep langdurig-episodisch gebruikers $54 \%$ de stap tot stoppen op eigen initiatief genomen, in de groep continu gebruikers $44 \%$ (tabel 2).

De huisartsen is ook gevraagd of zij de patiènten, die nog steeds gebruikten, ooit hadden gemotiveerd te minderen of te stoppen: bij de langdurig-episodisch gebruikers was dat in $40 \%$ het geval en in $49 \%$ bij de continu gebruikers. Bij $26 \%$ van de langdurig-episodisch en $31 \%$ van de continu gebruikers resulteerde dit volgens hen in een stoppoging.

\subsection{Beschouwing}

Dit onderzoek is verricht in een steekproef uit een negental huisartspraktijken, wier populatie qua demografische opbouw vergelijkbaar is met de nationale bevolking. ${ }^{13}$ Uitgangspunt voor" de hier gehanteerde indeling in gebruikersgroepen is de informatie van de patiënt-gebruiker; deze bepaalt immers veelal zélf de gebruikswijze. De gebruikte slaap- en kalmeringsmiddelen zijn op $1 \%$ na benzodiazepinen, zodat we ervan uitgegaan zijn dat gevonden resultaten representatief zijn voor benzodiazepine-gebruik. Omdat het onderzoek retrospectief van aard is, is de mogelijkheid van 'recall bias' niet uitgesloten.

Deze werd echter zo veel mogelijk beperkt door gebruik te maken van de gegevens van de apotheekselectie, zodat personen, die vergeten waren het slaap-en/of kalmeringsmiddel te vermelden ( $35 \%$ van de respondenten), alsnog benaderd konden worden met vragen omtrent het gebruik ervan. De andere vorm van vertekening door vergeten van feiten heeft vooral te maken met de tijd-as, hetgeen bij langdurig gebruik een rol kan spelen. Rekening houdend met de non-respons is de groep langdurig gebruikers met name in de categorie ouder dan 70 jaar in werkelijkheid mogelijk groter dan door ons gevonden.

In onze steekproef vormden de langdurig-gebruikers veruit de meerderheid, wawruit het belang blijkt wan nader onderzoek van deze groep gebruikers.

Geruststellend is dat de meeste huisartsen op de hoogte bleken te zijn van het benzodiazepinegebruik van hun patiënten, vaker bij langdurig den bij kortdurend gebruik; dat zou echter erop kunnen wijzen dat kortdurend gebruik en de reden daarvoor aan hun aandacht ontsnappen, met het mogelijke risico van sluipenderwijs overgaan in langdurig gebruik. 
Huisartsen bleken veelal te weten waarvoor het middel in de onderzoeksperiode gebruikt werd, maar bij langdurig gebruik in meerderheid niet (meer) op de hoogte te zijn van de beginklacht; dit is waarschijnlijk het gevolg wan het feit, dat in rum de belft van de gevallen van langdurig gebruik, het niet de huisarts zelf is geweest die het eerste voorschrift gaf, maar naar alle waarschijnlijkheid diens voorganger.

Langdurig gebruikers gaven in meerderheid aan weinig last van bijwerkingen te hebben en bleken in de helft van de gevallen (zeer) tevreden te zijn over het middel. Begrijpelijkerwijs bleek in deze groep de bereidheid gering om het gebruik te minderen of te stoppen. Toch is gemiddeld twaalf procent van hen gestopt, waarvan een op de vijf uit angst voor 'verslaving". Dat afhankelijkheid bij met name langdurig-continu gebruik daadwerkelijk een rol kan spelen, wordt onderstreept doordat afhankelijkheid gemeten naar de medicijnverslavingsindex alleen in de langdurig-continu gebruikersgroep groter bleek te zijn dan bij kortdurend-eenmalig gebruikers; de score op de verslavingsindex was betrekkelijk laag voor alle groepen, hetgeen overeenkomt met de resultaten van het onderzoek van De Berk. ${ }^{2}$ Bovendien was afhankelijkheid door langdurig-continu gebruikers minder vaak ontkend dan door de langdurig-episodisch gebruikers; dit verschil was nog groter ten opzichte van de kortdurend-eenmalig gebruikers.

Dat huisartsen niet zo vaak actief blijken te zijn (in minder dan de helft van de gevallen, een cijfer dat mogelijk zelfs nog geflatteerd is door sociaal wenselijke antwoorden) in het motiveren van langdurig gebruikers om te minderen of stoppen is te begrijpen: bij ongeveer de helft van langdurig gebruikers werd door de huisartsen aangegeven dat ze (zeer) tevreden waren over het behandeleffect en slechts bij een van de vijf werden bijwerkingen gemeld, waarvan als voornaamste genoemd werden afhankelijkheid en gewenning, tot uiting komend onder meer doordat er een hogere dosis of sterker middel werd gevraagd. De druk vanuit de patiënt daarbij blijkt aanzienlijk: de huisartsen rapporteerden slechts in ongeveer een op de zes gevallen voet bij stuk te houden en het voorschrift niet te veranderen. Al met al geen krachtige prikkels voor huisartsen om verminderen of stoppen van gebruik bij langdurig gebruikers te entameren.

Toch gaven langdurig gebruikers aan dat bij stoppogingen de huisarts een belangrijk persoon is: als over minderen gesproken werd, gebeurde dat in bijna driekwart van de gevallen met de huisarts en ruim de helft gaf aan de huisarts de meest geschikte persoon te vinden als begeleider bij stoppogingen; en als er gestopt werd, had in een kwart van de gevallen de huisarts daarbij geholpen, (waar tegenover staat dat door ruim eenderde van de stoppers werd aangegeven dat op eigen kracht te hebben gedaan).

Weliswaar is er verschil tussen gebruikers en huisartsen in het opgegeven aantal 'stoppers", met name bij de langdurig-episodisch gebruikers; er blijkt echter een vrij grote groep langdurig gebruikers te zajn die niet kan of wil stoppen noch mét, noch zónder steun. 


\subsection{Conclusie}

Van de gebruikers zelf mag men niet veel initiatieven verwachten om langdurig benzodiazepine-gebruik te minderen of te stoppen. Als eenmaal het besluit tot stoppen genomen is, is de uitvoering niet eenvoudig, ook al volgt men daarbij een aantal richtlijnen. ${ }^{14,15}$ Helaas is er weinig eerstelijns literatuur met betrekking tot de meest effectieve en doelmatige manier van het motiveren tot stoppen van een (tevreden) gebruiker. ${ }^{16}$

Het is dus alleszins van belang langdurig gebruik te voorkómen en daartoe bij het starten voorzorgsmaatregelen te treffen:

- de vraag naar een slaap- en/of kalmeringsmiddel is veelal mede ingegeven door een eerder gevormde mening over deze middelen, enerzijds op basis van informatie hierover door verwanten, vrienden, kennissen en media, anderzijds door eigen, voorgaande ervaringen in het gebruik van deze middelen. ${ }^{17}$ De huisarts dient de juistheid van deze mening te toetsen alvorens deze middelen voor te schrijven;

- bij het eerste voorschrift dient ook informatie gegeven te worden over mogelijk nadelige effecten van het voorgeschreven middel met name in relatie tot de duur van gebruik. Hiermee is bovendien te voorkomen dat achteraf door langdurig gebruikers gesteld wordt dat hen die informatie onthouden is bij de start van het gebruik; ${ }^{17}$

- bij het eerste voorschrift van een slaapmiddel zou de NHG-standaard "Slapeloosheid en slaapmiddelen' als richtlijn aangehouden moeten worden; ${ }^{18}$

- wil men langdurig gebruik van benzodiazepinen voorkómen dan dient bij het -herhaald. voorschrijven de beginklacht uitgangspunt te blijven; veranderingen in thet klachtenpatroon vereisen een nieuwe aanpak.

- volgt men de adviezen om deze middelen voor beperkte duwr voor te schrijven, dan zal vanzelfsprekend gezocht moeten worden naar alternatieven voor behandeling van de problemen waarvor het middel gebruikt wordt;

- herhalingsrecepten wia de balie zijn pas verantwoord na een aantal spreekuurcontacten; de patiënt zou ook daama minimaal eens per half jaar het spreekuur dienen te bezoeken.

Tenslotte zouden huisartsen geholpen zijn als zij "risico-gebruikers" zouden kunnen determineren, teneinde hiermee in het prescriptiebeleid en begeleiding rekening te kunnen houden.

Concluderend kan gesteld worden: 'Bezint eer gij begint'. En als er begomnen wordt, is daarmee de kous niet af, integendeel: begeleiding is en blijft noodzakelijk. 


\section{Dankbetuiging}

Een woord wan dank zijn we verscinuldigd aan het Praeventiefonds, dat ons onderzoeksproject "chronisch psychofarmacagebruik in de eerste lijn" (projectn 28-2186) financieel ondersteunde. Voor hun inzet bij dit anderzoek gaat onte dank ook wit nar onze research-assistentes Monique Latour en Karin Aretz, evenals maar de deelnemende artsen en hur assistentes wan gezondheidscentra Hoensbnok en Withus te Venlo, huisartsenpraktijken Medisch Contum Putstraat te Landgraaf, 'Voenendaal' te Voerendaal, Kaiser-Veldhuizen te Eygelshoven, Soomers te Kerkrade en Govaert-Leclercq te Stein, huisantspraktijken Guldemond te Ubachsberg en Van der Ploeg te Kerkrade. 


\section{Literatuur}

Plagge HWM, Vissers FHJ A, Pouls K, De Geus CA. Het woorschrij ven van geneesmiddelen zonder artspatiènt contact in de huisartspraktijk. Huisarts Wet $1988 ; 31: 120-3$. De Berk HAA. Over gebnuk van benzodiazepinepreparaten in de huisartsenpraktijk. Dissentatie 1988 Nijmegen. ISBN 90-9002477-8. Lagro-Janssen ALM, Liberton IJW. Profielen van regelmatige gebnikers van benzodiazepinen in een huisartspraktijk. Ned Tijuschr Geneeskd 1993; 137:1969-73. Habraken M, Blondeel L, Soenen K. Is langdurig gebruik van benzodiazepinen zinvol? Opvattingen van gebruikers en voorschrij vers. Huisarts Wet 1994; $37(7)$ : 285-8. Vissers EHJ A, Knotnenus JA, Van der Grinten RF, Van der Horst FGEM. Langdurig gebruik van slaapen kalmeringsmiddelen in de huisartspraktijk. Huisarts Wet 1993; 36(12):405-8. Van der Laar JW. Afhankelijkheid van benzodiazepinen; omvarg risico's en eventuele verschillen tussen de middelen onderling. Ned tijdschr Geneeskä 1984; 128: 809-14. Ziman FG. Kort-en langwerkende benzodiazepinen. Ned Tijdschr Geneeskd 1988; 132: 1917-21.

8 Kamphuisen HAC. Sllecht slapen door slaapmiddelen (Rebound insomnia'). en de plaats van zopiclon. Ned Tijdschr Geneeskd 1992; 136: 556-8.

9 Zitman FG. Verslaving aan benzodiazepinen? Is het een probleem en kan de huisarts er wat aan doen? Bujblijwen 10, 1994; nr 2; 40-5.

10 Van Steenkiste M, de Roeck J. Afhankelijkbeid en abstinentiewerschijnselen bij gebruik van benzodiazepinen. Ned Tijdschr Geneeskd 1986; 130: 1224-7.

11 Metsemakers IFM, Höppener P. Knottnerus JA, Kocken RJJ, Limonard CBG. Computerized health information in The Netherlands: a registration network of family practices. Br I Gen Pract 1992; 42: 1026.

12 Norusis MJ. SPSS, Advanced Statistics. SPSS incorporation. Michighan, Chicago, Illinois. 1993, release 6.0. ISBN 0-13-178831-0.

13 Metsemakers JFM. Unlocking patient"s records in general practice for research, medical education and quality assurance: the Registration Network Family Practices. Dissertatie juni 1994, Rijksuniversiteit Limburg. ISBN 90-5170-279-5. Anonymus. Stoppen met benzodiazepinen. Geneesmiddelen bulletin 1994; 28, nr 12: 98-101.

15 Eijkelenboom PR, Kunistingh Neven A. Uitsluipen van chronusch slaapmiddelengebnik, een handleiding. Tijdschr $v$ Huisartsgeneeskunde 1994; 11 (4): 303 8.

16 Vissers FHJA, Knottnerus JA, Van der Grinten RF, Van der Horst FGEM. Interventies in de eerste lijn bij langidurig gebruik van benzodiazepinen. Een literatuuronderzoek. Huisarts Wet 1997; 40(6); 244-7. Haafkens $J$. Rituals of silence. Long-term tranquiliser use by women in the Netherlands. A social case 5tudy. Dissertatie 1997 Amsterdam. ISBN 90-5589-062-6.

18 Kruistingh Neven A, De Graaff WJ, Lucassen PLBJ, Springer MP, Bonsema K, Dijkstra RH, FelixScollaart B. NHG-standaard Slapeloosheid en Shapmiddelen. Huisarts Wet 1992;35(5):212,9 

boofdstuk 10

Psychosociale problemen en gebruik van slaap- en kalmeringsmiddelen. 


\section{Abstract}

Objective. To investigate psychosocial determinamts of users of hypnotic or tranquillizing drugs.

Setting. 11 general practices, members of RegistratieNetwerk Huisartspraktijken (RNH) of the University of Maastricht (UM).

Method. A sample of 705 persons who use(d) hypnotic and/or tranquillizing drugs and a group of controls, matched on practice, sex and age, were interviewed by questionnaire. The problem list of the electronic medical record of both groups was also analysed, searching for psychosocial problems. The users were divided in three categories: short-term users ( $\leq 3$ months), episodic (long-term) users and continuous (long-term) users.

Results. In comparison with controls, during one year all users experienced more long-term life problems. They asked more often help for solving those problems. For all persons at the end of the year $75 \%$ of the problems was unsolved.

The short-term users had different characteristics in comparison with non-users: they were less content, had more health problems, asked more often for help in problems with their neighbours or in relational problems and had more psychological problems (especially surmenage) in their problem list. The episodic users had a more depressive behaviour in coping their life-problems, they asked more often for help in relational problems or health problems and their problem list contained more psychological problems. The continuous users were more frequently suffering from somatic problems and felt less happy. Also, they asked more often for help in problems with their own health problems. In their problemlists more psychological problems were found.

Conellusion. It seems that not the experienced life problems but coping with some of these problems are determinants of users of hypnotic or tranquillizing drugs. Episodic users have more depressive reactions while the continuous users experience more somatic suffering.

Key words. hypnotic drugs, tranquillizing drugs, benzodiazepines, psychosocial determinants, family practice. 


\section{0..1 Inleiding}

Het gebruik van slaap- en kalmeringsmiddelen is reeds lang een veel voorkomend fenomeen. Reeds in de oudheid werden kruiden en plantextracten, zoals valeriaan, gebruikt. Sinds de benzodiazepinen op de markt zijn gebracht (het eerste middel was chloordiazepoxyde in 1960), vormen deze de meest gebruikte slaap- en kalmeringsmiddelen. Uit internationaal vergelijkend onderzoek in 1981 bleek dat de prevalentie van benzodiazepinegebruik in Nederland $7,4 \%$ was. ${ }^{1}$ Nationaal onderzoek in 1987 toonde een prevalentie van $9,0 \%$ bij vrouwen en $4,6 \%$ bij mannen. Eénderde van deze prescripties betrof langdurig gebruik. ${ }^{2}$ In vergelijking met andere West-Europese landen is Nederland een land met een gematigde geneesmiddelenconsumptie per hoofd van de bevolking. In 1995 had 9,1\% van de totale kosten van de gezondheidszorg in Nederland betrekking op farmaceutische hulp, het laagste percentage van alle West-Europese landen. Met één op de vijf voorgeschreven geneesmiddelen betrekking hebbend op het centraal zenuwstelsel (pijnstillers, slaap- en kalmeringsmiddelen, antidepressiva e.d.) scoort deze categorie in Nederland echter het hoogst, twee maal zo veel als de daaropvolgende categorieën geneesmiddelen voor hart-vaatstelsel, maag-darmkanaal en luchtwegen (1996). ${ }^{3}$

De gebruikers van slaap- en kalmeringsmiddelen zijn te onderscheiden in kortclurend en langdurig gebruikers, waarbij de langdurig gebruikers nog te verdelen zijn in een groep continu gebruikers (dagelijks en blijvend) en een groep die dit niet doet (episodisch). De diverse categorieën hebben onderling hun eigen kenmerken (hoofdstuk 8 ). ${ }^{8}$

Langdurig gebruik van slaap- en kalmeringsmiddelen heeft risico's in de vorm van bijwerkingen (bijvoorbeeld sufheid, verminderd reaktievermogen, verminderde concentratie, spierslapte, moeheid), afhankelijkheid of ontwenningsreacties en is daarom niet aan te raden. ${ }^{4-7}$ Toch worden deze middelen veelal jaren achter elkaar geslikt. ${ }^{8}$

Het stoppen van deze medicatie is een moeizaam gebeuren, hetgeen mede zijn oorzaak heeft in de tevredenheid van de gebruiker over de werking van het middel. ${ }^{9,10}$ Hier geldt dan ook het adagium: "bezint eer ge begint".

Uit diverse eerstelijns- en bevolkingsonderzoeken blijkt dat vrouwen en ouderen relatief vaak langdurig gebruiken. ${ }^{2,11-24}$ Andere kenmerken van langdurig gebruikers die naar voren komen zijn: het hebben van meerdere gezondheidsproblemen ${ }^{12-16,20,21,23,24}$, psychologische ${ }^{12,17,22}$, psychische problemen ${ }^{11,15,16}$ en een lage opleiding. ${ }^{13,15,16}$ In enkele studies worden het blanke ras $^{12,15}$ en sociale status (weduwnaren, WAO-ers en werklozen) ${ }^{16,22}$ genoemd, evenals financiële problemen en isolement. ${ }^{19}$

Als de huisarts adequaat wil inspelen op de problematiek van (langdurig) gebruik van slaapen kalmeringsmiddelen, is het van belang dat hij inzicht heeft in kenmerken van deze doel- 
groep. Daarbij is van speciaal belang in welke mate langdurig gebruikers met psychosociale problemen geconfronteerd worden en op welk wijze zij met deze problemen omgaan. Doel van dit onderzock is derhalve het beschrijven van persoons- en gedragskenmerken, en in het bijzonder wan psychosociale problematiek van (langdurig) gebruikers en hun hulpvraag op dit gebied.

Het ging daarbij on de volgende vraagstellingen:

1. In hoeverte zijn er verschillen in persoons- en gedragskenmerken tussen gebruikers en nietgebruikers van slaap- en kalmeringsmiddelen?

2. Welke psychosociale problemen doen zich voor bij gebruikers en niet-gebruikers?

3. In hoeverre is er een verschil tussen gebruikers en niet-gebruikers ten aanzien van probleemoplossing en de bulpvraag daarbij?

\subsection{Methode.}

\section{Algemeen}

Het onderzoek geschiedde met behulp van een schriftelijke enquête. Het werd van december 1993 tot juni 1994 uitgevoerd in 11 huisartsenpraktijken, waarin 33 huisartsen werkzaam waren. De onderzoekspopulatie is geselecteerd uit de ingeschreven populatie van 30 jaar en ouder. De selectie van gebruikers vond plaats op twee manieren: een voorselectie door apothekers en een populatie-survey. Er werd en kontrolegroep van niet-gebruikers geselecteerd, paarsgewijs gematcht op basis van leeftijd en geslacht, telkens uit dezelfde praktijk.

Voor het onderzoek werd gebruik gemaakt van het onderzoeksbestand van het RegistratieNet Huisartspraktijken (RNH) van de Universiteit wan Maastricht (UM). Dit geautomatiseerde bestand bestaat naast cen leeftijd - en geslachtsregister uit patiènt-achtergrondgegevens (burgerlijke staat, woonwerband, opleiding, verzekeringsvorm), en probleemlijsten als een onderdeel wan de medische verslaglegging in de hüsartspraktijk. De probleemlijst van een patiënt bevat alle voor de gezond heid relevante problemen en diagnosen, welke langer dan 6 maanden duren, dan wel permanent of recidiverend van belang zijn, geregistreerd volgens de International Classification of Primary Care (ICPC). ${ }^{25-28}$ Dit onderzoeksbestand omvatte in december 1993 gegevens van 59395 personen $(49 \% \mathrm{M}, 51 \% \mathrm{~V})$. Deze populatie is wat betreft demografische gegevens (leeftijd, geslacht, wijze van verzekering, opleiding en woonverband) vergelijkbaar met de Nederllandse bevolking. ${ }^{26}$ Het RNH bestand wordt door het Medisch en Maatschappelijk Informatie Centrum van de Universiteit Maastricht (MEMIC) beheerd. 


\section{Procedure en meetinstrumenten}

Personen van 30 jaar en ouder ontvingen een postenquéte, die vragen omvatte omtrent achtergrondvariabelen, medicatiegebruik in het jaar voorafgaand aan het werzenden van de enquête, gebruik van genotmiddelen (koffie, tabak en alcohol), ervaren wan lichamelijk en psychisch welbevinden, alsook de volgende meetinstrumenten: een vragenlijst ter detectic van excessief alcoholgebruik (CAGE-lijst), de Eenzaamheidslijst, de Hopkins Symptom Checklist (HSCL, verkorte versie), de Utrechtse Copinglijst, de Groningse Lijst Langdurige Moeilijkheden (GLLM) en een schaal voor de kwaliteit van leven. ${ }^{29-35}$ Ook was een vragenreeks opgenomen, waarin de mening gepeild werd over het gebruiken van slaap- en kalmeringsmiddelen. ${ }^{36}$ De CAGE-lijst geeft weer of er sprake is van alcoholverslaving. De score van de Eenzaamheidslijst geeft een maat voor eenzaamheid. De Hopkinslijst meet kwantitatief de ervaren gezondheid. De Utrechtse Copinglijst meet het reageren op stressvolle gebeurtenissen (copinggedrag). De GLLM inventariseert langdurige moeilijkheden; deze lijst werd op empirische basils nog aangevuld met drie items: moeilijkheden in verband met het verlies van een dierbaar persoon, moeilijkheden in verband met het werzorgen van een chronisch zieke of een invalide persoon thuis en moeilijkheden in verband met de eigen gezondheid. De vrangenreeks omtrent de mening over het gebruik van slaap- en kalmeringsmiddelen heeft een variatiebreedte van 7 28 (laag betekent een negatief en hoog een positief oordeel); op de schaal voor de kwaliteit van leven kan ervaren kwaliteit van leven visueel aangegeven worden. Aan diegenen die in deze vragenlijst een slaap- en/of kalmeringsmiddel vermeldden, werd een tweede enquête gestuurd met vragen, die betrekking hadden op het gebruik van vermelde medicament(en). Deze tweede vragenlijst bevatte vragen over de aard en omvang van het medicamentgebruik, verdeeld in drie tijdvakken (periode vóór 1 oktober '92, periode van 1 oktober '92 tot 1 oktober ' 93 , periode vanaf 1 oktober ${ }^{9} 93$ ).

wat betreft de wijze van selectie van patiënten werden de praktijken verdeeld in twee groepen .

a) Voor negen praktijken werd door apothekers een overzicht gemaakt van patiénten van 30 jaar en ouder, die in de periode vanaf 1 oktober ' 92 tot 1 oktober '93 slaap-en/of kalmeringsmiddelen afgehaald hadden. Na selectie in de praktijken werden deze patiënten $(n=1724)$, evenals de controlepersonen ( $n=1723$ ) (geselecteerd door het MEMIC, op leeftijd, geslacht en praktijk gematched), schriftelijk benaderd met het verzoek aan het onderzoek deel te nemen.

b) In twee praktijken werd, vanwege het ontbreken van een voorselectie, een populatie-survey gehouden om gebruikers van slaap- en kalmeringsmiddelen op te sporen. Een op de drie mensen van 30 jaar en ouder werd door het MEMIC uit het RNH-bestand geselecteerd. Schriftelijk werden de geselecteerde patiẻnten $(n=1265)$ verzocht deel te nemen aan het enquête-onderzoek. Uit de groep respondenten die in de eerste enquête geen slaap- en/of kalmeringsmid- 
del vermeldden werd de controlegroep geselecteend, wederom gematcht op leeftijd, geslacht en praktijk.

\section{Datawerwerking}

De antwoorden van de enquêtes werden met behulp van het SPSS-programma bewerkt en geanalyseerd. ${ }^{37}$ De gebruikers van slaap-en/of kalmeringsmiddelen werden, op basis van de gegevens over het gebruik verdeeld in twee groepen: kortdurend en langdurig gebruikers (langdurig is langer dan 3 maanden). Alleen voor de praktijken waar geen selectie door apotheken plaats had gevonden werden daartoe de medische dossiers van deze praktijken gebruikt. Langdurig gebruik werd nog onderverdeeld in episodisch (meerdere episodes) en contimu gebruik. Voor kortdurend gebruik werd deze indeling achterwege gelaten omdat de groep episodisch gebruikers slechts 18 personen telde. Deze groep kortdurend-episodisch gebruikers bleek ten opzichte van de eenmalig gebruikers minder vrouwen te bevatten, maar er was geen verschil in leeftijdsverdeling noch in de top-3 van de gebruikte slaap-en/of kalmeringsmiddelen.

De gebruikers van slaap en kalmeringsmiddelen werden aldus in drie groepen verdeeld: kortdurend gebruikers (KG), langdurig-episodisch gebruikers (LEG) en langdurig-continu gebruikers (LCG). Ze werden met niet-gebruikers (NG) vergeleken wat betreft leeftijd en geslacht, achtergrondvariabelen, probleemaanbod en probleemverwerking, coping, ervaren gezondheid, sociale steun en gebruik van genotmiddelen.

\section{Statistische bewerking}

De drie gebruikersgroepen werden vergeleken met de niet-gebruikers. De data zijn per groep gepresenteerd door middel wan percentages of gemiddelden. Vanwege de matching op leeftijd en geslacht zijn deze twee variabelen in de vergelijkende analyses niet meegenomen. Voor de bivariate analyse werd voor nominale schallen de chi-kwadraat toets of de exacte toets van Fisher gebruikt; voor ordinale schalen de t-toets of de Mann-Whitney toets. Onderzochte variabelen werden significant verschillend beschouwd als de $p$-waarde $<0,05$ was, waarbij 4 significantieniveaus onderscheiden werden, respectievelijk $0,05,0,01,0,005$ en 0,001 .

Bij een te zeer gering aantal waamemingen worden geen toetsresultaten gepresenteerd. Door middel van logistische regressie is nagegaan welke variabelen samenhangen met de diverse vormen van gebruik. Hierbij zijn de diverse groepen gebruikers steeds vergeleken met de niet-gebruikers. In deze analyse is door middel van stratificatie op leeftijd en geslacht rekening gehouden met de gematchte opzet van het onderzoek. De verkregen odds ratio's zijn vanwege de relatief geringe populatie-prevalentie te interpreteren als relatieve risico's. ${ }^{38}$ 


\subsection{Resultaten}

\section{Algemeen}

Respons: na voorselectie door apotheek en MEMIC werden door de huisartsen 5945 personen geschikt geacht te participeren aan het onderzoek. Op basis van de geschatte grootte van de onderzoekspopulatie werden van deze groep at random 4583 personen benaderd met het verzoek mee te doen aan de postenquête. De respons op de eerste enquete bedroeg 2502 personen (55\%). Er werd aan 997 gebruikers verzocht een tweede enquête in te vullen. De respons van deze groep was $705(71 \%$ ) (figuur 1 Thoofdstuk 7 ).

De uitval gedurende het onderzoek bedroeg in total 115 personen, (verhuisd/andere huisartsi, overleden, slechte kwaliteit invulling, medicament niet gebruikt, recall probleem, gebruik buiten registratieperiode, niet in staat mee te doen, verkeerde leeftijdselectie, onbekend), waarvan 62 in de eerste fase van het onderzoek en 53 in de tweede fase.

Non-respons: Bij de eerste enquêteronde waren in de gebruikersgroep van de praktijken mêt. voorselectie in de non-responsgroep ( $n=835$ ) meer ouderen $(>70$ jaar) dan bij de respondenten $(p<0,05)$ en meer mensen zonder partner, meer ziekenfondswerzekerden en meer laag opgelei den. De non-responsgroep bevatte ook meer personen met een probleemlijst zónder actieve problemen en minder met een lijst waarop 6 of meer actieve problemen woorkwamen $(p<0,001)$. De groep controlepersonen vam deze praktijken liet hetzelfde beeld zien, alleen was hier geen verschil in de actieve problemen op de probleemlijst en waren er bij de non-respondenten meer lijsten zónder inactieve problemen. In de praktijken zónder voorselectie waren de non-respondenten $(n=494)$ op de eerste enquête qua leeftijd en geslacht niet verschillend van de respondenten.

De non-respondenten van de tweede enquête (alleen de gebruikersgroep van de praktijken mét voorselectie werd geanalyseerd) verschilden niet van de respondenten qua geslacht, wel qua leeflijd: in de non-responsgroep kwamen meer jongeren (30-39 jaar) voon, terwijl in de categorie 50-59 jaar minder personen te vinden waren.

De onderzoekspopulatie. Voor het onderzoek werden uiteindelijk 1588 personen in de analyses opgenomen. Deze waren onderverdeeld in 883 niet gebruikers (NG), 138 kortdurend gebruikers (KG), 335 (langdurig-) episodisch gebruikers (LEG) en 232 (langdurig-) continu gebruikers (LCG). De controlegroep was gemiddeld 56 jaar. In de groep kortdurend gebruikers waren de mensen gemiddeld 47 jaar; in de twee groepen langdurig gebruikers 58 respectievelijk 63 jaar. Wat betreft geslachtsverdeling was in de controlegroep $67 \%$ van het vrouwelijk geslacht, bij de kortdurend gebruikers $61 \%$, bij de episodisch gebruikers $68 \%$ en bij de continu gebruikers $67 \%$

De gebruikte middelen. Het meest voorgeschreven middel was bij kortdurend gebruik diaze- 
tabel 1. Overaicht van gebruikte medicatie in de diverse gebruikerggnepen. Percentages.

\begin{tabular}{|c|c|c|c|c|c|c|}
\hline medicamenten & $\begin{array}{l}\text { kontdurend } \\
\text { gebruxik (KG) } \\
n=138\end{array}$ & 90 & $\begin{array}{l}\text { langdung-epi } \\
\text { gebruk (LEG } \\
n=335\end{array}$ & $\%$ & $\begin{array}{l}\text { langdurigoo } \\
\text { gebnik }(\mathrm{LC} \\
\mathrm{n}=232\end{array}$ & $\%$ \\
\hline $\begin{array}{l}\text { benzo- } \\
\text { diazepinen }\end{array}$ & $\begin{array}{l}\text { dituepain } \\
\text { oxazepan } \\
\text { demazepam } \\
\text { overig } \\
\text { combinatie* }\end{array}$ & $\begin{array}{r}32,7 \\
25,4 \\
17,4 \\
15,8 \\
2,9\end{array}$ & $\begin{array}{l}\text { oxazeprm } \\
\text { lemazepan } \\
\text { diazepam } \\
\text { overig } \\
\text { combinatie }\end{array}$ & $\begin{array}{r}33,3 \\
22,4 \\
1,5,2 \\
22,8 \\
0,6\end{array}$ & $\begin{array}{l}\text { oxazepan } \\
\text { temazepam } \\
\text { nitraziepam } \\
\text { overig } \\
\text { combinatie }\end{array}$ & $\begin{array}{r}27,2 \\
12,1 \\
11,2 \\
44,8 \\
0,4\end{array}$ \\
\hline $\begin{array}{l}\text { restgroep stadp-en kal } \\
\text { meringsmiddelen }\end{array}$ & $\begin{array}{l}\text { aoplicone } \\
\text { barbiturat } \\
\text { overig. }\end{array}$ & $\begin{array}{c}2,2 \\
- \\
=\end{array}$ & $\begin{array}{l}\text { zoplicone } \\
\text { barbiturat } \\
\text { overig }\end{array}$ & $\begin{array}{l}1,5 \\
- \\
-\end{array}$ & $\begin{array}{l}\text { zoplicone* } \\
\text { barbituraat } \\
\text { overig }\end{array}$ & $\begin{array}{c}2,6 \\
1,3 \\
-\end{array}$ \\
\hline valleriaan & alle & 2,2 & alle & 3,0 & alle & 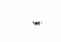 \\
\hline $\begin{array}{l}\text { homeopathische mid. } \\
\text { delen }\end{array}$ & atlie & 1,4 & alle & $\mathbb{1 , 2}$ & alle & 0.4 \\
\hline
\end{tabular}

* betreft combinatie benzodiazepine en een ander middel zoals een pijnstiller

* benzodiazepine-achtig hypnoticum

tabel 2. Percentage van ervaren problemen in éen jaar, die genoemd werden als oorzaak van de klacht waarvoor een slaap-en/of kalmeringsiniddel gebrulkt werd.

\begin{tabular}{|c|c|c|c|}
\hline problemen met/op gebied van: & $\begin{array}{l}\mathrm{KG}^{*} \\
\mathrm{n}=138\end{array}$ & $\begin{array}{l}\mathrm{LEG}^{*} \\
\mathrm{n}=335\end{array}$ & $\begin{array}{l}\mathrm{LCG}^{*} \\
\mathrm{n}=232\end{array}$ \\
\hline werk/ huishoudelijk werk & 75 & 71 & 63 \\
\hline school/studie & 33 & 25 & 50 \\
\hline Financièn & 83 & 77 & 87 \\
\hline huisvesting & so & 43 & 32 \\
\hline leefsituatiefburt & 69 & 63 & 70 \\
\hline $\operatorname{sex}$ & 82 & 77 & 77 \\
\hline godsdienst/geloof & 50 & 60 & 40 \\
\hline manaschappij-ontwikkelingen & 38 & 60 & 50 \\
\hline partuen: & 88 & 73 & 62 \\
\hline ouders & 67 & 64 & 50 \\
\hline kinderen: & 64 & 66 & 72 \\
\hline schoonouders & 50 & 59 & 30 \\
\hline broedrs/zussien & 67 & 67 & 84 \\
\hline mensen in de burut & 75 & 55 & 77 \\
\hline wrienden/kennissen & 40 & 56 & 40 \\
\hline contact met anderent & 44 & 51 & 27 \\
\hline verlies vand dierbaar persoon & 69 & 61 & 78 \\
\hline verzorgen chron zieke thuis & 60 & 75 & 77 \\
\hline eigen gezondheid & 92 & 90 & 92 \\
\hline & - & $\cdots$ & - \\
\hline gemiddelde percentage van alle problemen & 63 & 63 & 61 \\
\hline
\end{tabular}

KGi: kortdunend gebnuikers 
pam $(32,7 \%)$, bij langdurig gebruik oxazepam $(33,3 \%$ bij episodisch en $27,2 \%$ bij continu gebruik). Wat betreft de diverse gebruikte benzodiazepinen had de groep continu gebruikers de grootste spreiding. Van de onderzochte groep gebruikers $(n=705)$ gebruikte $7 \%(n=42)$ een slaap- of kalmeringsmiddel dat niet afkomstig was uit de benzodiazepinereeks. Homeopatische middelen werden in $0,4 \%$ tot $1,4 \%$ van de gevallen gemeld (tabel i).

Het gebruik van nog andere (tweede of derde) slaap-en/of kalmeringsmiddelen in de onderzoeksperiode kwam bij de kortdurend gebruikers in $5,8 \%$ van de gevallen voor; bij de langdurig-episodisch gebruikers $8,4 \%$ en bij de langdurig-continu gebruikers $12,9 \%$.

Probleemervaring en aanleiding voor gebruik. Bij vergelijking van de in de loop van een jaar ervaren problemen en de door de gebruiker aangegeven oorzaak van de klacht(en) waarvoor een psychofarmacon geslikt werd, bleken deze voor alle drie de gebruikersgroepen gemiddeld ruim $60 \%$ congrwent te zijn. Gezondheidsproblemen scoorden in dit opzicht voot alle drie de gebruikersgroepen het hoogst ( $>90 \%$ ) (tabel 2 ).

\section{Groepen gebruikers en niet-gebruikers met elkaar vergeleken.}

Persoonskenmerken.(tabel 3) Ten opzichte van de niet-gebruikers (NG) waren er bij de kortdurend gebruikers (KG) meer hoger opgeleiden en meer personen in het arbeidsproces betrokken. Ze meldden vaker een grotere mate van eenzaamheid. Volgens hun score op de copinglijst hadden ze vaker een sterker depressief reactiepatroon en gaven ze vaker aan hun emoties meer te uiten, meer palliatieve reacties (zoals afleiding zoeken, ontspannen, roken, drinken) te vertonen, meer sociale steun te zoeken. Er werd vaker lichamelijk en geestelijk lijden ervaren en kwaliteit van leven werd vaker slechter beoordeeld. Er waren meer personen die alcohol gebruikten en rookten. Bij de episodisch gebruikers (LEG) waren ten opzichte van niet-gebruikers meer personen die niet in het arbeidsproces betrokken waren "Er waren meer personen die aangaven dat er sprake was van een grotere mate van eenzaamheid. De score op de copinglijst gaf aan dat hun depressief reactiepatroon sterker was en palliatieve reakties bij hen meer voork wamen evenals een afwachtende houding. Ook in deze groep gaf men waker aan lichamelijk en geestelijk lijiden te ervaren en werd kwaliteit van leven slechter beoordeeld. $\mathrm{Bij}$ de continu gebruikers (LCG) waren ten opzichte van de niet-gebruikers meer personen die een lager opleidingsniveau hadden, geen partner hadden, niet meer aan het werk waren en verplicht verzekerd waren. Ze vertoonden vaker een grotere mate van eenzaamheid. Ook waren er meer personen die volgens de score op de copinglijst minder actief waren in de aanpak van problemen, een sterker depressief reactiepatroon hadden en een sterker vermijdingsgedrag hadden. In de groep continu gebruikers bleken meer mensen te zijn die vaker aangaven lichamelijk en geestelijk lijden te ervaren en de kwaliteit van hun leven slechter te beoordelen. Er waren in deze groep minder personen die koffie en/of alcohol gebruikten, maar meer personen die 
rookten.

Ten aanzien van gezondheid en kwaliteit van leven was het verschil met de niet-gebruikers het grootst bij de continu gebruikers.

Tabel 3. Achtergrondvariabelen en persoonskenmerken van niet-gebruikers vergeleken met die van de drie groeppen gebruikers. Gemiddeliden en percenitages.

\begin{tabular}{|c|c|c|c|c|c|c|c|}
\hline & $\begin{array}{l}\mathrm{NG} \\
\mathrm{n}=883\end{array}$ & $\begin{array}{l}K G \\
n=138\end{array}$ & $p$ & $\begin{array}{l}\mathrm{LEG} \\
\mathrm{n}=335\end{array}$ & $p$ & $\begin{array}{l}\mathrm{LCG} \\
\mathrm{n}=232\end{array}$ & $p^{*}$ \\
\hline gemiddeld opleidingsnivean (1) & 1.5 & 1,6 &, 049 & 1,5 & ns & 1,3 & .000 \\
\hline sociale kenmerken & $\%$ & $\%$ & $P$ & 留 & $p$ & $\%$ & $p^{* * *}$ \\
\hline $\begin{array}{l}\text { zonder partner/alleenstiand } \\
\text { niet in arbeidsproces } \\
\text { ziekenfondsverzekerd }\end{array}$ & $\begin{array}{l}27,5 \\
61,8 \\
70,3\end{array}$ & $\begin{array}{l}25,0 \\
41,6 \\
68,2\end{array}$ & $\begin{array}{c}\mathrm{ns} \\
000 \\
\mathrm{~ns}\end{array}$ & $\begin{array}{l}30,7 \\
71,6 \\
66,3\end{array}$ & $\begin{array}{c}\mathrm{ns} \\
002 \\
\mathrm{~ns}\end{array}$ & $\begin{array}{l}41,0 \\
83,9 \\
79,8\end{array}$ & $\begin{array}{l}, 000 \\
, 000 \\
, 005\end{array}$ \\
\hline psychische kentmerken & mean & mean & $p$ & mean & $p$ & mean & $p^{*}$ \\
\hline eenzaamheid ${ }^{(2)}$ & 3,9 & 4,3 & .008 & 4,4 &, 000 & 4,7 & .000 \\
\hline \multicolumn{8}{|l|}{ coping (2) } \\
\hline -actief aanpakken & 4,2 & 4,4 & ns & 4,1 & ns & 3,7 & .000 \\
\hline -depressief reageren & 3,8 & 4,4 &, 000 & 4,9 & .000 & 5,0 &, 000 \\
\hline -expressie van boosheid & 4,5 & 5,0 & ,001 & 4,7 & ns & 4,2 & ns \\
\hline "genuststellende gedachten & 4,2 & 4.1 & ns & 4,2 & ns & 4,0 & ns \\
\hline -palliatief reageren & 40 & 4,5 & .002 & 4,3 &, 003 & 4,3 & ns \\
\hline -sociale steun zoeken & 4,2 & 4,5 & .011 & 4,3 & ns & 4,1 & ns \\
\hline -vermijden/afwachten & 4,2 & 4,1 & nsi & 4,4 & .032 & 4,5 &, 004 \\
\hline \multicolumn{8}{|l|}{$\mathrm{HSCL}^{(2)}$} \\
\hline ervaren psychisch lijiden & 3,8 & 4,2 & .001 & 4,6 & .000 & 4.9 &, 000 \\
\hline ervaren somatisch lijden & 3,9 & 4,3 & 002 & 4,6 &., 000 & 5,1 & .000 \\
\hline ervaren psychosomatisch Hijden & 3,6 & 4,1 &, 001 & 4,5 & .000 & 5,0 & .000 \\
\hline oordeel lichärnelijk functioneren ${ }^{(1)}$ & 2,6 & 2,5 & .029 & 2,4 & .000 & 2,1 & ,0000 \\
\hline oordeel gesestelijk lungtioneren $(1)$ & 2,8 & 2,7 & .002 & 2,6 & 000 & 2,5 &, 000 \\
\hline zich gelukkigyoelen & 1,4 & 1,5 & .000 & 1,7 & 000 & $\mathbb{I}, 8$ &, 000 \\
\hline levreden $z \mathrm{ijn}{ }^{(3)}$ & 1,3 & 1,4 &, 000 & 1,5 & .000 & 1,6 & .000 \\
\hline oordeel over kwaliteit van leven ${ }^{(1)}$ & 2,5 & 2,3 & 001 & 2,2 &, 000 & 2,0 & .000 \\
\hline gewoontevorming & $\mathscr{W}$ & $\%$ & $p$ & $\%$ & $p$ & $\%$ & $p^{* * *}$ \\
\hline gebruik vam koffie & 95,0 & 94,9 & ns & 92,8 & ns. & 91,3 &, 034 \\
\hline gebruik van alcohol & 58,7 & 71,0 &, 006 & 62,4 & ns. & 38,5 &, 000 \\
\hline gebruik van tabak & 28,3 & 55,1 &, 000 & 30,8 & ns & 37,9 &, 005 \\
\hline alcohol werslaafd (CAGE) & 8,0 & 10,1 & $n s$ & 10,7 & ns & 6,1 & $\mathrm{~ns}$ \\
\hline
\end{tabular}

NG: iniet-gebruikers KG: kortdurend gebnikers LEG: langdurig-episodisch gebruikers LCG: langdurig-continu getruikers

* p-waarde gebaseerd op Mann-Whitney toets bij ordinale variabelen.

** p-waarde gebaseerd op chi-kwadraattoets bij dichotome variabelen.

(1): gecartegoriseerd in 3 subschalen; variatie 1-3: niveau $1=$ laag, niveau $3=$ hoog

(2): gecategoriseerd op basis van cumulatieve percentages in 7 subschalen; variatie 1-7: $1=$ laagste $7=$ hoogste

(3): gecategoriseerd in 3 subschalen: variatie 1-3:1=hoog $3=1 \mathrm{agg}$ 
Mening over gebruik wan slaap-en kalmeringsmiddelen. Op cen zevental statements betreffende het nut van gebruik van deze middelen ( $\alpha$-Crohnbach 0,56 , variatie score 7-28) werd door de niet-gebruikers gemiddeld 14,0 gescoord. De kortdurend gebruikers scoorden hoger $(p<0,001)$ met een gemiddelde van 15,3 ; de langdurig gebruikers scoorden nog hoger $(p<0,0$ 01) waarbij het gemiddelde voor de episodisch gebruiker 16,5 bedroeg en voor de continu gebruiker 17,5 .

Voorkomen wan langdurige problemen in de loop van én jaar.(tabel 4 en tabel 6) De top drie van ervaren problemen was voor de gebruikersgroepen en de niet-gebruikers dezelfde: problemen met eigen gezondheid op de eerste plaats en daaropvolgend problemen op het werk/werkzaamheden thuis en het verlies van een dierbaar persoon; bij de continu gebruikers waren nummer twee en drie omgekeerd: op de tweede plaats stond verlies van een dierbaar persoon, gevolgd door problemen met werk. De mate van scoren per probleemgebied verschilde onderling wel.

tabel 4. Ervaren problemen in een periode van één jazar. Percentages per groep, chi-kwadraat toets. "Top-3 (vet gedrukt).

\begin{tabular}{|c|c|c|c|c|c|c|c|}
\hline problemen met/op gebied van: & $\begin{array}{l}\mathrm{NG}^{*} \\
\mathrm{n}=8.83\end{array}$ & $\begin{array}{l}\mathrm{KG}^{*} \\
\mathrm{n}=138\end{array}$ & $\mathrm{p}$ & $\begin{array}{l}\text { LEG* }^{*} \\
\mathrm{n}=335\end{array}$ & $\mathrm{p}$ & $\begin{array}{l}\mathrm{LCG}^{*} \\
\mathrm{n}=232\end{array}$ & $\mathrm{p}$ \\
\hline werk/werkzaamheden thuis & 30,4 & 55,8 & .000 & 42,8 & .000 & 43,1 & .000 \\
\hline school/opleiding & 1,0 & 3,7 & .015 & 2,1 & ns & 0,4 & ns \\
\hline Financièn & 16,2 & 23,9 & .025 & 21,9 & .020 & 21,6 & ns \\
\hline huiswesting & 6,6 & 8,7 & ns & 7,5 & ms & 9,1 & ns \\
\hline leefsituatie in buurt & 10,1 & 13,8 & nst & 14,7 & .025 & 15,7 & .019 \\
\hline sex & 18,0 & 24,6 & ns & 24,3 & .014 & 23,7 & .050 \\
\hline godsdienst/geloof & 3,6 & 3,6 & RMS & 6,3 & .042 & 8,3 & .003 \\
\hline maatschappelijke ontwikkelingen & 12,7 & 10.9 & nIs & 18.9 & .006 & 19,9 & .006 \\
\hline partner & 16,9 & 29.7 & .000 & 24,5 & .003 & 21,0 & $\mathrm{~ns}$ \\
\hline oudters & 7,7 & 18,1 & .000 & 11,2 & ns & 8,8 & $\mathrm{~ns}$ \\
\hline kinderen: & 19,6 & 22,5 & $n s$ & 30,1 & .000 & 33,0 & .000 \\
\hline sehoonouders & 4,9 & 7,3 & ns: & 7,9 & .043 & 4,0 & ns \\
\hline broers/zussen & 16,3 & 21,7 & ns & 20,2 & nsi & 18,7 & Mis \\
\hline mensen in uw buurt & 9,2 & 12,3 & $\mathrm{~ns}$ & 12,3 & ns. & 13,5 & ns \\
\hline vrienden/kennissen & 7,3 & 8,7 & $\mathrm{~ns}$ & 10,0 & ns & 7,8 & ns \\
\hline contacten met anderen & 7.9 & 10,9 & ns & 13,3 & .004 & 12,2 & .039 \\
\hline verllies valn cen dierbaar persoon & 26,0 & 36,2 & .012 & 33,2 & .012 & 46,5 & .000 \\
\hline verzorging van chron. zieke thuis & 7.7 & 8,0 & $\mathrm{~ns}$ & 10,0 & ns & 15,9 & .000 \\
\hline eigen gezondheid & 53,4 & 74,6 & .000 & 76,9 & .000 & 84,3 & .000 \\
\hline overige nao & 8,2 & 12,5 & - & 14,2 & - & 12,7 & - \\
\hline
\end{tabular}

MG: niet-gebruikers

KG: kortdurend gebruikers LEG. langdurig-episodisch gebrulikens LCG: lamgdurig-continu gebruikers 
tabel 5. Probleemervaring, onopgeloste problemen en hulpvraag bij niet-gebruikers (NG), kortdurend gebruikers (KG), langdurig-episodisch (LEG) en langdurig-continu gebruikers (LCG). Gemiddelde, percentages.

\begin{tabular}{|c|c|c|c|c|c|c|c|}
\hline & $\begin{array}{l}\mathrm{NG} \\
\mathrm{n}=883\end{array}$ & $\begin{array}{l}\mathrm{KG} \\
\mathrm{n}=138\end{array}$ & $\mathrm{p}$ & $\begin{array}{l}\text { LEG } \\
\mathrm{n}=335\end{array}$ & $\mathrm{p}$ & $\begin{array}{l}\mathrm{LCG} \\
\mathrm{n}=232\end{array}$ & $\mathrm{p}^{*}$ \\
\hline \multicolumn{8}{|l|}{ gemiddeld anatal ervaren problemen } \\
\hline in $92-93$ & 2,7 & 4,0 &, 000 & 3,9 &, 000 & 4,0 &, 000 \\
\hline percentage personen zónder ervaren & & & & & & & \\
\hline problemen in $922^{4} 93$ & 14,4 & 3,6 & .000 & 6,0 &, 000 & 3,9 &, 000 \\
\hline $\begin{array}{l}\text { percentage personen bij wie cén of } \\
\text { metr problemen niet ziin opgelost }\end{array}$ & 68.2 & 88,4 & 000 & 77.9 & .000 & 80.6 & 000 \\
\hline $\begin{array}{l}\text { percentage personen die bij éen of } \\
\text { meer problemen hulp vroegen }\end{array}$ & 56,2 & 79.7 &, 000 & 78,8 &, 000 & 84,1 & .000 \\
\hline
\end{tabular}

percentage personen, die bij oplossing. van problemen hulp gevraagd hebben. bijow :

\begin{tabular}{|c|c|c|c|c|}
\hline huisarts & 41,6 & 41,7 & 45,7 & 41,2 \\
\hline specialist & 18,8 & 8.4 & 14,6 & 15,8 \\
\hline AMW**** & 19,9 & 17,6 & 16,6 & 34,0 \\
\hline RLAGC** & 8,6 & 12,7 & 19,0 & 14,5 \\
\hline 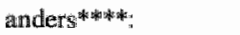 & 41,8 & 33,4 & 40,7 & 57,0 \\
\hline familie/gezin & 12,9 & 35,1 & 21,0 & 28,9 \\
\hline -niet verwanten & 10,8 & 17,6 & 13,8 & 8,4 \\
\hline -andere $1 \mathrm{e}$ lijn & 26,3 & 13,5 & 19,6 & 10,8 \\
\hline De lijn & 5,2 & 9,5 & 5,8 & 8,4 \\
\hline -categorale zorg & 1,6 & - & - & 8,4 \\
\hline werkkring & 13,4 & 8,1 & 10,9 & 7,3 \\
\hline -overheid & 7,7 & 1,4 & 10,9 & 7,3 \\
\hline huisvesting & 6,2 & 5,4 & 5,8 & 6,0 \\
\hline -verzekering &. & - & 0,7 & \\
\hline -diversen & $1.1,9$ & 8,1 & 8,0 & 14,5 \\
\hline combinaties & 4,0 & 1,3 & 3,5 & \\
\hline
\end{tabular}

* p-warde van t-test

* Combinatives van scores waren mogelijk

* AMN: algemeen maatschappelijk werk

RIAGO: regionale instelling voor gesstelijke gezondheidszorg

fauiliejgezin: partner, kinderen, ouders, broers/zusters

niet verwanten: vrienden, kennissen, buurtomgeving

andlere eersteljinshulpverleners: andere huisarts, fysiotherapeut, wijkverpleegster, gezinsverzorgster,

dietist, tundarts, psycholoog, pastor, alternatieve hulpwerlener

Oe lijn: gemeenschappelijk administratiekantoor ( $\mathrm{GAK}$ ), bedrijfswereniging, bedrijfsarts, gemeentelijke

gezondheidsdienst (GOD), jeugdarts, kinderbescheriming

categorale zorg: consultatiebureau voor alcohol en irugs (CAD), revalidatiekliniek, asthmacentrum,

crisiscentrum, verpleeghuis, psychiatrische kliniek

werkkring: collega, baas, chef, vakbond, arbeidsbureau

overheid: sociale zaken, belastingen, politie, brandweer, milieuxaken

huisvesting: maikelaar, huisbaas, huisvestingsbureau, bejaardenhuis, indicatieconımissie bejaardenhui-

xen

verzekering; ziekenfonds, ziektekostenverzekering, rechtsbijstand

diversen: restgroep 
Het gemiddeld aantal ervaren problemen (tabel 5) in de loop van een jaar lag bij de gebruikers hoger dan bij de niet-gebruikers; het niet ervaren van enig problemen was frequenter bij de nivet gebruikers.

Probleemoplossing en hulpvraag (tabel 5 en tabel 6). Van alle ervaren problemen waren bij gemiddeld drie kwart van de gebruikers en niet-gebruikers éen of meer problemen aan het eind van de onderzoeksperiode niet opgelost, bij de gebruikers significant meer dan bij niet-gebruikers. Op het niveau van de diverse probleemvelden waren tussen de groepen onderling de volgende verschillen: de kortdurend gebruikers bleven wat betreft problemen met huisvesting met meer onopgeloste probleemsituaties zitten, de episodisch gebruikers wat betreft problemen met hun kinderen en de continu gebruikers wat betreft problemen met werk/huishoudelijk werk, kinderen, mensen in de buurt en met verlies van een dierbaar persoon.

Het vragen om hulp bij én of meer problemen geschiedde door de niet-gebruikers gemiddeld in $56 \%$ en door alle drie de gebruikersgroepen in gemiddeld $80 \%$ van de gevallen. Ten opzichte van niet-gebruikers werd door de kortdurend gebruikers in vijf ervaren probleemvelden vaker hulp gevraagd voor de oplossing van die problemen; de instelling of persoon bij wie men hulp vroeg verschilde in vier probleemvelden. Door de episodisch gebruikers werd in vier probleemvelden vaker hulp gezocht; bij wie hulp gevraagd werd verschilde in zes problemvelden. De continu gebruikers verschilden qua hulpvraag in zeven, qua persoon/instelling in tien probleemvelden met de niet-gebruikers.

Het vragen om hulp bij andere personen/instellingen dan huisarts, specialist, AMW en RIAGG gebeurde bij de kortdurend gebruikers in $9 \%$ van de gevallen minder dan bij niet-gebruikers; bij de continu gebruikers $19 \%$ meer. Hierbij werd door de gebruikers twee maal zo vaak de familie/het gezin ingeschakeld. De niet-gebruikers zochten vaker hun heil bij andere eerstelijns hulpverleners en in hun werkkring .

De probleemlijsten.(tabel 7) Op zoek naar psychosociale kenmerken, vastgelegd door de artsen in hun probleemlijsten, werden de tractus psychische stoomissen $(P)$ en sociale problemen $(Z)$ van gebruikers en niet-gebruikers vergeleken. Alle gebruikersgroepen hadden van beide tractus in hun probleemlijsten ten opzichte van de niet-gebruikers meer actieve en/of inactieve problemen (meer probleemregels). De kortdurend gebruikers verschilden met de niet-gebruikers in neurasthenie, problemen met werk en met partner. Beide groepen langdurig gebruikers verschilden met de niet-gebruikers in gevoelens van angst/nervositeit, depressiviteit, slaapstoornissen, alcohol- en medicamentmisbruik, angststoornissen, depressie, neurasthenie, problemen mer partner en kinderen; daarnasst verschilden de episodisch gebruikers nog in hysterie/hypochondrie en de continu gebruikers in psychosen, persoonlijkheidsstoomissen en in problemen met ouders/familie en met het werlies van een dierbaar persoon. 
tabel 6. \$ignificante werschillen in probleemervaring in het afgelopen jaar, hulpvaag hierbij en probleemoplossing (onopgeloste problemen) in de drie gebruikersgroepen ten opzichte van de niel-gebnikers.

\begin{tabular}{|c|c|c|c|c|c|c|c|c|c|c|c|c|}
\hline \multirow{2}{*}{$\begin{array}{l}\text { probllecrivelden } \\
\text { problemen metop gebied van }\end{array}$} & \multicolumn{3}{|c|}{$\begin{array}{l}\text { kortaturend } \\
\text { gebraikers } \\
\text { E } \quad \mathrm{O}\end{array}$} & \multirow{2}{*}{ 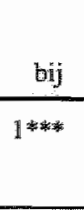 } & \multicolumn{4}{|c|}{$\begin{array}{l}\text { langdurig-epissodisch } \\
\text { gebruikers } \\
E \quad O \quad H \quad \text { bij }\end{array}$} & \multicolumn{4}{|c|}{ 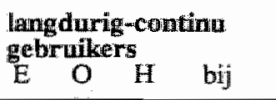 } \\
\hline & 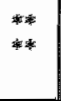 & & & & $\begin{array}{l}* * * \\
* * 3 *\end{array}$ & & 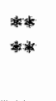 & $1 * * * * * *$ & *at & * & $*$ & 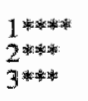 \\
\hline 2. school/studie & $*$ & & & & & & & & & & & \\
\hline 3.funancien & * & & & & * & & & & & & $*$ & $3^{*} *$ \\
\hline 4. huisvesting & & 4 & & & & & & & & & & $3 * * * *$ \\
\hline 5.leefsituatie in uw buturt & & & & & : & & & & * & & & $3^{* \infty \cdots \infty}$ \\
\hline $6 . \operatorname{sex}$ & & & wat & 4 & * & & & $4^{*}$ & * & & & $1 *$ \\
\hline 7.geloof & & & & & & & & & * & & & \\
\hline $\begin{array}{l}\text { 8.matschappelijke ontwikke- } \\
\text { lingen }\end{array}$ & & & & & 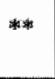 & & & & **\$ & & * & 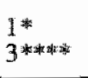 \\
\hline 9.partner & 事 & & wow & & 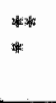 & & * & $\begin{array}{l}1 * \\
3 * \\
4 *\end{array}$ & & & *** & $1^{1}$ \\
\hline 10.owders & $*$ & & & & & & & & & & & \\
\hline 11.kinderen & & & & & * & * & & & *at & 䟢 & & \\
\hline 12.schoonouders & & & * & & * & & ** & & & & & \\
\hline 13.browrs/zusters & & & & & & & & $4 *$ & & & & \\
\hline 14. mensen hn uw buturt & & & * & & & & & & & \% & & \\
\hline 15.vrienden/kennisien & & & & & & & & & & & & \\
\hline 16.cothtacten met anderen & & & & & 然* & & & & * & & & $4 *$ \\
\hline 17. verlies dierbakar persoon & 极 & & 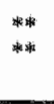 & 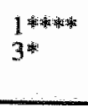 & * & & & $\begin{array}{l}1^{*} \\
4^{*}\end{array}$ & is: & 的䊉文 & $* *$ & 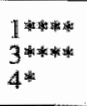 \\
\hline $\begin{array}{l}\text { 18. verzorging wam chronisch } \\
\text { ziakefinvalide thuis }\end{array}$ & & & & & & & & & & & * & \\
\hline 19.elgen gezondheid & 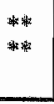 & & & $1 *$ & $* * * *$ & & * & 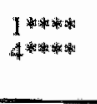 & 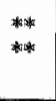 & & * * * & 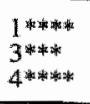 \\
\hline
\end{tabular}

E; ervaren problemen in eem jaar

O: problemeru die onopgelost zijn

H: problemen warbij hulp gevraagd is All: hulpwtag bij: $1=$ hiisarts $2=$ specialist 3 =algemeen maatschappelijk werk $4=$ riagg men, met gelbruk van vehillen in onderzochte variabelen ten opzichte van niet-gebruikers zijn in de tabel opgeno Een gearceerd veld betekent minder of lager niveaus: * $p<0.05, * * 0<0,01, * * 0<0,005, * 4 * 0<0,001$ 
tabel 7. Vergelijking van niet-gebruikers met gebruikersgroepen wat betneft het voorkomen van probleemregels (klachten/diagnosen) in zake psychische stoornissen (P) en sociale problemen (Z) in hun probleemlijsten. Percentages.

\begin{tabular}{|c|c|c|c|c|c|c|c|}
\hline & $\begin{array}{l}\mathrm{NG} \\
\mathrm{n}=883 \\
\mathrm{\%}\end{array}$ & $\begin{array}{c}\mathbb{K G} \\
\mathrm{n}=138 \\
\%\end{array}$ & & $\begin{array}{l}\text { LEG } \\
\mathrm{n}=335 \\
\end{array}$ & & $\begin{array}{c}\mathrm{LCG} \\
\mathrm{n}=232 \\
\%\end{array}$ & \\
\hline ém of meer probleenregells in tractus $\mathrm{P}$ & 13,4 & 25,4 &, 000 & 40,3 & .000 & 53,9 & 000 \\
\hline Gen of meer probleemregels in tractus $Z$ & 13,5 & 22,7 & .019 & 20,0 & .045 & 27,2 & .000 \\
\hline \multicolumn{8}{|l|}{ tractus psychische stoomissen(P) } \\
\hline -gevoel van angst,spanning, nervositas (01) & 4,2 & 5,8 & ns & 14,0 &, 000 & $\mathbb{1 3}, 8$ & 1000 \\
\hline -gevoel van depressiviteit (03) & 0,9 & 0,7 & $\mathrm{~ns}$ & 4,2 &, 000 & 3,4 &, 004 \\
\hline -slaapstoornissen (06) & 0,3 & 0,7 & ns & 1,8 & .016 & 3,9 & .000 \\
\hline -alcoholmisbruik $(15 / 16)$ & 0,9 & 2,2 & ns & 3,3 & .003 & 6.9 &, 000 \\
\hline -medicamentmisbruik (18) & 0,1 & 0.7 & ns & 2,1 & .001 & 9,9 &, 000 \\
\hline -psychosen $(71 / 72 / 73)$ & 0,3 & 1,4 & ns & 1,2 & ns & 2,2 & .012 \\
\hline -angsstoornis (74) & 0,3 & 1,4 & ns & 1,5 & .040 & 2,2 & .012 \\
\hline thysterie, hypochondrie (75) & 1,2 & 1,4 & ns & 3,3 &, 017 & 3,0 & ns \\
\hline -diepressie $(76)$ & 2,3 & 2,9 & $\mathrm{~ns}$ & 7,5 &, 000 & 16,8 & .000 \\
\hline -neurasthenie, overspannen (78) & 1,5 & 4,3 &, 020 & 5,1 &, 000 & 5,2 &, 001 \\
\hline -persoonlijkheidsstoomis ( 80 ) & 0,1 & - & - & 0,6 & ns & 3,0 & .000 \\
\hline \multicolumn{8}{|l|}{ tractus sociale problemen( $Z$ ) } \\
\hline -problemen met werk (05/06) & 2,7 & 7,2 &, 006 & 2,4 & ns & 3.4 & ns \\
\hline -problemen met partner (12-14) & 4,4 & 10,9 &, 002 & 8.1 & .012 & 11,2 & ,000 \\
\hline -problemen met kinderen (16-18) & 1,1 & 1,4 & $\mathrm{~ns}$ & 3,9 &, 002 & 3,4 & ,013 \\
\hline -problemen met ouders/familie $(20-22)$ & 0,3 & 0,7 & ns & 0,3 & ns & 3,0 & .001 \\
\hline $\begin{array}{l}\text {-verlies van partmer, kind, ouder, familielid } \\
\qquad(15 / 19 / 23)\end{array}$ & 5,0 & 4,3 & ns & 5,4 & ns & 10,3 & 0002 \\
\hline
\end{tabular}

NG: niet-gebruikers KG: kortdurend gebruikers LEG: langdurig-episodisch gebruikers

LCG: langdurig-continu gebruikers

* P-waarde van chi-kwadraattoets, bij toepassing van Fishers Exact toets is waarde cursief gedrukt

\section{Gebruikers en niet-gebruikers, nader bekeken.}

De in de bivariate analyse significant verschillend bevonden variabelen bij vergelijking van niet-gebruikers met de drie groepen gebruikers werden in een regressie-analyse ingevoerd met 'gebruik' als afhankelijke variabele (tabel 8 ). De odds ratio's van de continue variabelen (depressief reageren, somatische schaal van Hopkinslijst, aantal P-regels in probleemlijst, oordeel over psychisch functioneren, gelukkig zijn en tevreden zijn) zijn ter vergelijking met de dichotome variabelen omgerekend voor een verschil van $2 x$ de standaarddeviatie (OR').

Ten opzichte van de niet-gebruikers waren de volgende kenmerken in afnemende mate verschillend bij de kortdurend gebruikers: er werd meer hulp gevraagd bij problemen met mensen in de buurt (OR 4,6) en bij relatieproblemen (OR 4,2), ze hadden vaker problemen met eigen gezondheid (OR 2,1), ze hadden een groter aantal probleemregels in de tractus psychische stoornissen in de probleemlijst (OR' 1,8$)$ en ze waren minder tevreden $\left(\mathrm{OR}^{\prime \prime} 1,4\right)$. 
Tabel 8. Het gereduceerd model van de logistische regressie voor paycho-sociale kenmerken van de drie gebruikersgrotpen: KG (korthurend gebruik) LEG (langdurig-episodisch gebruik) LCG (langdurigucontinu gebruik). Gebruik als afhankelijke variabele.

\begin{tabular}{|c|c|c|c|c|c|c|}
\hline wariabelle* & $\begin{array}{l}\mathrm{KG} \\
\mathrm{OR}\end{array}$ & $95 \% \mathrm{BI}$ & $\begin{array}{l}\text { LEG } \\
\text { OR }\end{array}$ & $95 \% \mathrm{BI}$ & $\begin{array}{l}\text { LCG } \\
\text { OR }\end{array}$ & $95 \% \mathrm{BI}^{*}$ \\
\hline minder tevreden zijn & 1,42 & $1,09-1,84$ & - & - & - & - \\
\hline depressief teageren & - & - & 1.20 & $1,1,5-1,25$ & - & - \\
\hline ervaren lichamelijk lijden & - & - & - & - & 1,08 & $1,03-1,14$ \\
\hline oordeel psychisch functioneren & - & - & - & - & 0,50 & $0,36-0,71$ \\
\hline múnder gelukkig zija & - & - & - & - & 1,47 & $1,10-1,95$ \\
\hline gebruik koffie & - & - & - & . & 2,45 & $1,16-5,18$ \\
\hline gebruik alcohol & - & - & - & - & 1,67 & $1,12-2,49$ \\
\hline ervaren probleem 11 & - & - & - & - & 2,19 & $1,40-3,42$ \\
\hline ervaren probleem 17 & - & - & - & - & 1,69 & $1,13 \cdot 2,52$ \\
\hline ervaren probleen 19 & 2,11 & $1,36-3,27$ & - & - & - & - \\
\hline hulpvraag bij probleem 9 & 4,20 & $1,88-9,38$ & 3,03 & $1,53-6,01$ & * & - \\
\hline hulprrag bij probleem 14 & 4,62 & $1,26 \cdot 16,87$ & $\therefore$ & & - & - \\
\hline hulpvraag bij probleem 19 & - & - & 2,33 & $1,29-4,21$ & 3,30 & $1,52-7,13$ \\
\hline $\begin{array}{l}\text { aantal psychische stoornissen an } \\
\text { probleemlijst }\end{array}$ & 1,47 & $1,09-1,98$ & 2,28 & $1,79-2,91$ & 2,88 & $2,20-3,79$ \\
\hline
\end{tabular}

* probleem 9: met partner probleem 11: met kinderen probleem 14: met mensen in uw buurt probleem 17: met verlies van dierbaar persoon probleem 19: met eigen gezondheid

** OR: odds ratio ${ }^{(1,3)}$ Bl: $95 \%$ betrouwbaarheids interval ${ }^{(2)}$

noot 1:

OR $=\left(\right.$ odds $\left.s_{v}\right):\left(\right.$ odds $\left.s_{0}\right)=\left[\mathrm{p}_{v} /\left(1-\mathrm{p}_{\mathrm{v}}\right)\right]:\left[\mathrm{p}_{0} /\left(1-\mathrm{p}_{0}\right)\right]$

oudds: de kans gebruiker te zijn gedeeld door de kans geen gebruiker we zijn bij danwezigheid van variabele , odcks: de kans gebnuiker te zijn gedeetld door de kans geen gebruiker te zijn bij afwezigehid van variabele , Ps: de kans gebruiker te zijn gegever de anwezigheid wan een variabele $1-p_{y}$ : de kans geen gebraiker te zijn gegeven de aanwexigheid van cen variabele. $\mathrm{p}_{0}$ : de kans gebnuiker te zijn gegeven de fwezigheid van een variabele 1. $p_{0}$ : de kans geen gebruiker te zijn gegeven de afwezigheid van ten variabele

neot 2: $95 \%$ B1: 95\% betrou wbarheids interval rond de odds ratio is berekend middels: $\mathrm{e}^{[\mathrm{B}-(1,96 \times \mathrm{SE})]}<\mathrm{OR}<\mathrm{e}^{[\mathrm{B}+(1,96 \times \mathrm{SE})]}$

noot 3: odds ratio $(\mathrm{OR}) \approx$ relatief risisco $(\mathrm{RR})$ gezien de relatief geringe populatiefrequentie. $^{38}$ 
Bij de episodisch gebruikers waren in aflopende mate de volgende kenmerken verschillend met niet-gebruikers: ze hadden een groter aantal probleemregels in de tractus van psychische stoornissen (OR' 4,4), ze reageerden vaker met depressiviteit bij het omgaan met problemen $\left(\mathrm{OR}^{\prime} 4,3\right)$, ze vroegen vaker hulp bij relatieproblemen $(\mathrm{OR} 3,0$ ) en bij problemen met eigen gezondheid (OR 2,3).

Bij de continu gebruikers werden de volgende verschillen gevonden ten opzichte van de nietgebruikers: ze hadden een groter aantal probleemregels uit de tractus psychische stoornissen (OR' 9,2), ze gebruikten vaker koffie (OR 2,5), ze hadden vaker problemen met de kinderen $(2,2)$, ze ervoeren vaker meer lichamelijk lijden (OR' 2,0$)$, ze hadden vaker problemen met het verlies van een dierbaar persoon (OR 1,7), waren vaker minder gelukkig (OR' 1,5), gebruikten vaker alcohol (OR 1,7) en ze vroegen vaker hulp bij problemen met eigen gezondheid (OR $1,5)$; hun psychisch functioneren beoordeelden ze vaker minder goed (OR' 0,4 ).

\subsection{Beschouwing}

In 11 huisartspraktijken werd in een steekproef van patiënten gezocht naar psychosociale determinanten van gebruik van slaap- en kalmeringsmiddelen. De gebruikers bleken voornamelijk benzodiazepinen te gebruiken.

$\mathrm{Er}$ is getracht een profiel te schetsen van gebruikers aan de hand van persoons- en gedragskenmerken. Meest opvallende bevindingen waren dat ten opzichte van niet-gebruikers de kortdurend gebruikers minder tevreden over het leven waren, de episodisch gebruikers bij het verwerken wan onplezierige gebeurtenissen vaker reageerden met een depressief patroon en dat de continu gebruikers hun psychisch functioneren slechter beoordeelden, minder gelukkig waren en meer lichamelijk lijden ervoeren.

Ten opzichte van de niet-gebruikers hadden alle groepen gebruikers meer problemen ervaren in de loop van ến jaar. De aard wan de problemen verschilde onderling niet, behalve bij de kortdurend gebruikers die meer problemen met hun gezondheid hadden en bij de continu gebruikers die vaker problemen hadden met hun kinderen en het verlies van een dierbaar persoon. Door de gebruikers werd vaker hulp gevraagd bij het oplossen van problemen: door de kortdurend gebruikers bij problemen met mensen in de buurt en bij relatieproblemen, door de episodisch gebruikers eveneens bij relatieproblemen en tevens bij problemen met eigen gezondheid en door de continu gebruikers bij problemen met eigen gezondheid. Als hulp gevraagd werd gebeurde dit het meest bij de huisarts; dit gold ook voor de niet-gebruikers. Bij de gebruikers bleken ten opzichte van niet-gebruikers gemiddeld meer personen voor te komen wan wie ervaren problemen aan het eind van de onderzoeksperiode niet opgelost bleken te zijn. 
De probleemlijsten in het medisch dossier bleken bij alle gebruikers meer psychische stoomissen te bevatten dan die van de niet-gebruikers; er was geen verschil in het aantal sociale problemen.

Het onderzoek is retrospectief van aard en daarmee voor een deel afhankelijk van de herinnering van de gebruiker. De recall bias kon beperkt blijven doordat de gebruikers reeds te voren bekend waren door middel van de selectie van apothekers (zie hoofdstuk 8). Omdat de controlegroep gematcht is op geslacht en leeftijd is een analyse van geslachts-en leeftijdsverschillen tussen gebruikersgroepen en niet-gebruikers niet mogelijk. De onderzochte persoonskenmerken missen een longindinaal karakter daar ze slechts eenmal gemeten zijn. Uitspraken over veranderingen hierin in de loop van de tijd kunnen niet gedaan worden. In de non-responsgroep bleken meer ouderen (>70 jaar) voor te komen. De omvang van de enquête zal mogelijk vooral voor ouderen een reden zijn geweest on niet mee te doen; het is heel wel mogelijk dat daarom beide groepen langdurig gebruikers groter zijn dan door ons gevonden is.

Het classificeren van diagnosen met behulp van de ICPC heeft zijn beperkingen omdat er uitgegaan wordt van categorieèn. Een tweede probleem is dat bij het diagnostiseren van psychische stoornissen huisartsen deze vaker op symptoomniveau beschrijven, waardoor deze psychische stoornissen minder duidelijk en minder gespecificeerd naar voren zullen komen. ${ }^{39}$

Als door mensen hulp gevraagd wordt in verband met langdurige moeilijkheden wordt de huisarts het meest hierbij betrokken. Hulpverlening in dit kader kan inhouden dat psychofarmaca worden voorgeschreven. Hierbij zal onder andere de aard van het probleem en de daaraam gekoppelde hulpvraag als ook het persoonlijk reageren op het probleem en persoonlijke omstandigheden van de patiënt een rol spelen. Tevens zal voor de huisarts de historie van de putiënt, weergegeven in de probleemlijst, van belang zijn in de keuze van interventie. Een aantal kenmerken in dit kader kunnen de huisarts aan het denken zetten over het risico varn langduriggebruik van slaap-en kalmeringsmiddelen.

Hulpwraag. Het hulp vragen bij een rouwproces, bij problemen met de kinderen of relatieproblemen en last but not least bij problemen met de eigen gezondheid doen zich vaker voor bij langdurig gebruikers. In combinatie met de bekende risicofactoren als een hogere leeftijd en het vrouwelijke geslacht ${ }^{2,9-22}$, bepalen ze de kans dat een persoon langdurig gebruiker is/wordt.

Persoonlijk reageren. Een depressief reactiepatroon komt in de groep episodisch gebruikers vaker voor. Zou het episodisch gebruik van slaap- en kalmeringsmiddelen samenhangen met periodes wan depressiviteit? Als dat het geval is, zouden antidepressiva beter op hun plaats zijin.

Continu gebruikers zijn vaker minder gelukkig, beoordelen hun psychisch functioneren van minder kwaliteit en ervaren meer lichamelijk lijden. Uit de literatuur is bekend dat een slechte- 
re lichamelijke en geestelijke gezondheid kenmerken zijn die samenhangen met langdurig gebruik. ${ }^{12-15,19,20,22,23}$ Het ervaren wan lichamelijk lijden, een kenmerk van continu gebruikers, zal een voor de hand liggende reden zijn zich bij hun huisarts te presenteren. Deze zal zich dan ook bewust moeten zijn van het gegeven dat lichamelijk lijden oorzaak kan zijn van klachten die aanleiding kunnen zijn tot het langdurig (gaan) gebruiken van psychofarmaca; een strikte indicatiestelling, hetgeen volgens de literatur nog wel eens ontbreekt ${ }^{2}$, en gedegen medicatiebewaking zijn aangewezen.

Persoonlike omstandigheden. Eenzaamheid, versterkt door problemen met kinderen en/of verlies van partner, kan psychische stoornissen met zich meebrengen die de kans vergroten psychofarmaca te gaan en/of te blijven gebruiken. Wil de huisarts deze kans verkleinen dan zal hij op zoek moeten gaan naar altematieven voor het gebruik van psychofarmaca.

Alle gebruikers oordelen positief over het mut van het gebruik van slaap-en kalmeringsmiddelen; dit past bij het gegeven dat door gebruikers weinig bijwerkingen ervaren worden door het gebruik, alsmede de tevredenheid van langdurig gebruikers over de werking van het middel; 8,10 objectieve informatie over voor- en nadelen van deze middelen is in deze van belang, zodat voorkomen kan worden dat langdurig gebruikers achteraf stellen dat hen die informatie onthouden is bij het starten wan het gebruik. 40

De probleemlijst. De huisarts heeft de beschikking over zijn probleemlijstregistratie. In de probleemlijsten van langdurig gebruikers zijn door de huisarts in ruim de helft van de gevallen psychische stoomissen en in ruim een $\mathrm{kwart}$ van de gevallen sociale problemen vermeld. Kenmerkende probleemregels voor psychische stoomissen bij langdurig gebruikes waren vooral klachten van angst/nervositeit en de diagnose depressie. Opvallend was dat behalve de diagnose depressie andere psychiatrische diagnosen (psychose, angststoomissen, persoonlijkheidsstoomissen) weinig woorkwamen. Problemen met partner en verlies van partner werden het meest als sociaal probleem vermeld. Al is het dan beperkt, de huisarts heeft zijn (potentièle) gebruiker al van een merkteken voorzien en zou daarmee meer rekening moeten houden.

Bij het inventariseren van langdurige problemen blijkt dat problemen met eigen lichamelijke gezondheid door gebruikers van slaap- en kalmeringsmiddelen vaker ervaren worden. Gezien de hogere leeftijd van de langdurig gebruikers zijn deze waarschijnlijk veelal te relateren aan chronische ziekten. Nader onderzoek naar de invloed wan lichamelijk lijden op het gebruik van deze middelen is noodzakelijk om determinanten wan dit gebruik volledig in beeld te kunnen brengen.

In het gebruik van genotmiddelen onderscheiden de langdurig-continu gebruikers zich van niet-gebruikers: er zijn meer personen die koffie en/of alcohol consumeren. De huissartsen blijken in de probleemlijsten van beide groepen langdurig gebruikers misbruik van alcohol vaker genoteerd te hebben. Dit betekent dat in verleden of heden dit probleem gespeeld heeft. 
Of er cen verband bestat tussen dit gegeven en het huidige gebruik van slaap- en/of kalmeringsmiddelen vergt verder onderzoek.

Ten behoeve van een strikte indicatiestelling woor behandeling met slaap-en kalmeringsmiddelen is een goede diagnosestelling gewenst. Het symptoomgericht diagnostiseren door huisartsen is in dezen een beperkende factor. Onderzoek onder langdurig gebruikers van slaap- en kalmeringsmiddelen naar het voorkomen van psychische stoornissen is gewenst. Hierbij is het noodzakelijk dat het classificatiesysteem van de ICPC met name de P-tractus vooral op diagnoseniveau meer gedetailleerd wordt.

Gebruikers van slaap-en kalmeringsmiddelen onderscheiden zich van niet-gebruikers. Wat betreft gedragskenmerken is het verschil als volgt: de kortdurend gebruikers zijn minder tevreden over het leven, de episodisch gebmikers vertonen vaker depressieve reakties bij het beleven van moeizame gebeurtenissen, terwijl de continu gebruikers vaker lichamelijk lijden ervaren en minder gelukkig zijn. Het is werder opvallend dat alle gebruikers vaker hulp vragen (wooral in het medisch circuit) bij het oplossen van verschillende langdurige problemen.

In geval van vragen om hulp bij relatieproblemen, rouwverwerking of eigen gezondheidsproblemen bij personen die een depressief reaktiepatroon hebben of een slechte gezondheid ervaren, moet de huisarts alert zijn op het risico van langdurig gebruik van slaap-en/of kalmeringsmiddelen.

\section{Dankbetuiging}

Ejen woord van dank zijn we verschuldigd aan het Praeventiefonds, dat ons onderzoeksproject "chronisch psychofiarmucagebruik in de eerste lijn" (projectrr. 28-2186) financieel onderstewnde. Voor hun inzet bij dit onderzoek gaat onze dank ook uit naar onze research-assistentes Monique Latour en Karin Aretz, evenals naar de deelnemende artsen en hum assistentes van gezondheidscentra 'Hoensbroek' te Hoensbroek, Withuis te Venlo en dr. w. Kleef te Manstricht, huisartsenpraktijken 'medisch centrum Putgrafo te Landgraaf," "Voerendaal' to Voerendaal, KajserVellhuizen to Eygelshoven, Soomers te Kerkrade en Govaert-Leclercq te Stein, huisartspraktijken Guldemond te Ubachsberg, Van der Ploeg te Kerkrade en Zwietering te Maastricht. 


\section{Lîteratuur}

Batter MB, Manheimer DI, Mellinger GD, Uhlenhuth EH. A cross-national comparison of anti-anxiety/sedative drugs use. Cur Med Res Opin 1984; 8(suppl 4): $5-20$

Van der Waals FW, Mohrs J. Foets M. Sex differences anong recipients of benzodiazepines in Dutch general practice. Br Med J 1993; 307: 363-7

Data en feiten 1996. Kostenoniwikkeling van de farmaceutische hulp. Stichting Farmaceutische Kengetal. len.

Van der Laan JW. Afhankelijkheid wan benzodiazepinen: omvang, risico's en eventuele verschillen tussen de middelen onderling. Ned Tijdschr Geneeskd 1984;128:817-9.

Steenkiste van M, Roeck de J. Afhankelijkheid en abstinentieverschijnselen bij gebruik van benzodiazepinen. Ned Tijdschr Geneeskd 1986; 130(27): 1224-7

Zitman FG. Kort-en langwerkende benzodiazepinen. Ned Tijdschr Geneeskd 1988; 132(42): 191,7-21

Anonymus. Stopper met benzodiazepinen. Gebu 1994; 28 (12): 98-101

Vissers FHIA, Van der Grinten RF, Van der Horst FGEM, Kester ADM, Knotmens JA. Slap-en kalmeringsmoiddelen in de huisartspraiktijk; gebruikswijze, redenem voor gebruik en kenmerken van gebruikers. Artikell wordt ter publicatie aangeboden.

Vissers FHIA, Knottmenus JA, Van der Grimten, Van der Horst FGEM. Interventies in de eersteling bij langdurig gebruik van benzodiazepinen. Huisarts Wet 1997; 40(6): 244-7

Wissers FHJA, Jongbloet A.l, Van der Grinten RF, Van der Horst FGEM, Knotnerus JA. Benzodiazepinen: de gebruiker en zijn huisarts. Bijwerkingen, satisfactie, afhankelijkheid en stoppen gezien door de bril van de gebruiker en zijn huisarts. Huisarts Wet $1998 ; 41(7): 323$.7

Mellinger GD, Balter MB, Manheimer DI, Cisin IH, Parry H. Psychic distress, life crisis and use of psychotherapeutic medications. Arch Gen Psychiatry 1978; 35: 1045-52.

Uhlemhuth EH, Balter MB, Lipman RS. Minor tranguillizers. Clinical comelates of use in an urban population. Arch Gen Psychiatry 1978; 35: 650-5.

Mellinger GD, Balter MB, Uhlenhuth EH. Prevalence and correlates of long term regular use of anxiolytics. JAMA 1984; $251: 375-9$

4 Wells KB, Kamberg C, et all. Health status, sociodemografic actors and the use of prescribed psychotropic drugs. Medical Care $1985 ; 23: 1295-1306$

Blijenberg-Ruis B, Garretsen HFL, Schwurman JH, Verdonk ALT. Het gebruik van slaap-en kalmeringsmiddelen. Een secundaire analyse van een Rotterdams onderzoek. T Soc Gezondheidsx 1986; 64: 491-7

Salinsky $\mathbb{J V}$, Dore $\mathrm{CJ}$. Characteristics of long term benzodiazepime users in general practice. J R Coll Gen Pract 1987; 202-4

Dunbar GC, Morgan DD. Perera KMH. The concurrent use of alcohol cigarettes and caffeine in british benzodiazepine users as measured by a general population survey. $\mathrm{Br}$ I Addiction $1988 ; 83: 689-94$.

Catalan J, Gath D, et all. General practice patients on long term psychotropic drugg. Br J Pyychiatry 1988 ; 152: $399-405$

Gene-Badia J, Blay-Pueyo C. Soler-Vila M. Risk factors in the use of benzodiazepines. Fam Pract 1988 ; $5: 283-8$

Dunbar GC, Pereta MF, Jenner FA. Pattems of benzodiazepine use in Great Brittain as measured by general population surwey. Br J Psychiatry 1.989; 155:836-4l.

1 Ashton H, Golding JF. Tranquillisers: prevalence, predictors and possible consequences. Data from a large United Kingdorn survey. Br J Addict 1989; 84:541-6.

2 Simpson RJ, Power $\mathrm{KG}$, et all. Controlled comparison of characteristics of long term benzodiazepine users in general practice. Br J Gen Pract 1990; 40;22,6

3 Lagro-Janssen T, Liberton IJW. Profielen van regelmatige gebruikers van benzodiazepwinen in een. hutisartispraktijk. Ned Tijuschr Geneseskd 1993; 137:1969-73

4 Mant A, Matrick RP, De Burgh S, Donelly N, Haal W. Benzodiazepine prescribing in general practice: dispelling some myths. Fam Pract: 1995; 12(1):37-43.

Metsemakers JFM, Hôppener P, Knottnerus JA, Kocken RJJ, Limonard CBG. Computerized health information in the Netherlands: a registration network of family practices. Brit J Gen Pract 1992; 42: 1026. 
26. Metsemakers IFM. Unlocking patient's records in general practice for research, medical education and quality assurance: the Registration Network Family Practices. Dissertatie juni 1994, Rijksuniversiteit Limburg. ISBN 90-5170-279-5.

27 Lamberts $\mathrm{H}_{3}$ Wood M. ICPC, International Classification of Primary Care. Oxford university press, New York, 1987. ISBN 0-19-261633-1.

28 Anonymus. ICHPPC-2-defined (inclusion criteria for the use of the rubrics of the International Classification of Health Problems in Primary Carey. Oxford University Press, 1983.

29 Wallace $\mathbb{P}$, Haines $A$. Use of a questionnaire in general practice to increase the recognition of patients with excessive alcohol consurnption. Br. Med J 1985; 290: 1949-53.

30 De Jong-Gierweld J, Kamphuis F. The developpement of a Rash-type loneliness scale. Applied Psychological Measurement 1985: 9: 289-99.

31 Anonymus. HSCL, Hopkins Symptom Checklist. In Luteyn F, Hamel L, Bouman T, Kok A. HSCL. Lisse: Swets en Zeitlinger, 1984.

32 Schreurs $P$, Wan de Willige $G$, Tellegen $B$, Brosschot J. UCL, Utrechtse Coping Lijst. Omgaan met problemen en gebeurtenissen. Handleiding. Vakgroep Kliwische Psychologie, Rijksuniversiteit Utrecht, 1993.

33 Anonymus. GLLM, Groningse lijst langdurige moeilijkheden. In Ormel J. Het Groningse eertselijnsproject: opxet en aanpak [intern rapport]. Groningen: Rijksuniversiteit Groningen, afdeling Sociale Psychia. trie, 1985 .

34 De Haes JCJM. Kwaliteit van leven van kankerpatienten. Proefschrift, Rijksuniversiteit Leiden. 1988

35 Andrews FM, Witney SB. Social indicators of well-being. Plenum Press, New York. 1976

36 De Berk HAA. Over het gebruik van benzodiazepinepreparaten in de huisartserpraktijk. Dissertatie. Nijmegen 1988. ISBN 90-9002477-8

37 Norusis MI. SPSS, Professional Statistics. SPSS incorporation. Michighan, Chicago, Illinois. 1993, release 6.0. ISBN 0-13-178831-0.

38 Schouten HJA. Klinische statistiek. Een praktische inleiding in methodologie en analyse. Houten: Bohn Stafleu Van Loghum 1995. ISBN 90-313-1968-6

39 Van Ree JW, De Vries MW. Praktisehe huissartsgeneeskunde. Psychiarrie. Bohn Stafleu Van Loghum. Houtem/Diegen 1997. ISBN 90-313-2043-9

40 Haafkens J. Ritualls of silence. Longaterm tranquillizer use by women in the Netherlands. A social case study [Dissertatie]. Amsterdam: het Spinhuis 1997. ISBN 90-5589-062-6 
hoofdstuk 11

Lichamelijke gezondheid en gebruik van slaap- en kalmeringsmiddelen. 


\section{Abstract}

Objective. To investigate somatic determinants of users of hypnotic or tranquillizing drugs. Setting. 11 general practices, members of RegistratieNetwerk Huisartspraktijken (RNH) of the University of Maastricht (UM).

Method. A sample of 705 persons who use(d) hypnotic and/or tranquillizing drugs and a group of controls, matched on practice, sex and age, were interviewed by questionnaire. The problem list of the electronic medical dossier of both groups was also analysed. The users were divided in three categories:" short-term users ( $\leq 3$ months), episodic (long-term) users and continu (long-term) wisers.

Results. About half of all users said that health problems were the cause of their drug use. Short-term users especially mentioned musculo-skeletal and digestive problems; episadic and continuous users muscullo-skeletal and circulatory problems. $76 \%$ of the latter asked their general practitioner (GP) for help in solving their health problems. Their complaints at that moment mostly were having disturbance of sleep or feeling anxious, tense or nervous. All users took more other medicaments and, connected to that, we found in their problem list more diagnoses of adwerse effects of medical treatment (especially adverse effects of pharmaceutical agents). The problem lists of all users contained more active problems. Comparing ICPCchapters of the problem lists, we found no differences between short-term users and controls. The episodic users had more problems in the following chapters: digestive system, psychological problems and female genital system; the continuous users differed only as to the psychological chapter.

Conclusion. Having health (somatic) problem, is a reason to seek care from the GP. In some people these health problems may cause psychological problems. The GP should try to solve these health problems before deciding to treat concomitant psychological problems with hypnotic or tranquillizing drugs. The problem list of all users is longer than that of the controls, while having psychological problems, mentioned in this problem list, is especially associated with long-term use.

Key words. hypnotic drugs, tranquillizing drugs, benzodiazepines, somatic determinants, family practice. 


\subsection{Inleiding}

Bekende kenmerken van langdurig gebruikers van slaap- en kalmeringsmiddelen zijn het vrouwelijk geslacht, een hogere leeftijd; daarnaast in minder sterke mate een lage socio-economische status, een lage opleiding, niet meer in het arbeidsproces zijn, geen partner hebben, psychologische problemen hebben, eenzaamheid en afwijkend copinggedrag (zie hoofdstuk 10). ${ }^{1-16}$ Men is geneigd gebruik van slaap- en kalmeringsmiddelen vooral in verband te brengen met deze psychosociale problemen van de patiënt. Patienten geven echter aan dat ook problemen met eigen lichamelijke gezondheid de oorzaak zijn van de klachten waarvoor deze middelen gebruikt worden: in twee studies werd op basis van enquêtering van patiënten vastgesteld dat voor $39-51 \%$ van de deelnemers ziekte of ziekte in de omgeving aanleiding was om cen benzodiazepine te gaan gebruiken; ${ }^{13,14}$ ook uit eerder gemelde resultaten van ons onderzoek blijkt dat problemen met eigen gezondheid volgens patiënten het hoogst scoorden als oorzaak voor alle vormen van gebruik van slaap- en kalmeringsmiddelen (hoofdstuk 10). Indien men zoekt naar kenmerken van gebruik van slaap- en kalmeringsmiddellen lijkt het zinvol zich niet alleen te richten op psychosociale aspecten van gezondheid maar ook op de lichamelijke aspecten ervan.

In hoeverre het hebben of verwerken van problemen met de lichamelijke gezondheid (in de tekst wordt hiervoor het begrip gezondheidsproblemen gebruikt, waaronder zowel lichamelijke klachten als diagnosen vallen) een rol speelt bij langdurig gebruik is op uiteenlopende manieren bestudeerd: aan de hand van het oordeell van de patiënt over zijn gezondheid, het inventariseren van gezondheidsproblemen door middel van vragenlijsten, analyse van het medisch dossier en frequentie van arts-patientcontacten. ${ }^{3-6,9,10,12-15}$

Deze onderzoeken over langdurig gebruik richtten zich op verschillende kenmerken van de lichamelijke gezondheid van de gebruikers: in het onderzoek van Bleyenberg beoordeelde de gebruiker zijn gezondheid slechter dan de nier gebruiker;" Dunbar wond dat de gebruikers twee jaar voorafgaand aan zijn onderzoek meer gezondheidsproblemen hadden (gehad) dan nietgebruikers; ${ }^{10}$ Simpson mat een hogere consultfrequentie bij gebruikers; ${ }^{12}$ in verschillende studies werd vastgestelid dat langdurig gebruikers meer gezondheidsproblemen hadden; $;^{3,5,6,9.12}$ Mellinger vond dat deze gezondheidsproblemen zich vooral afspeelden in de tractus circulatorius en locomotorius. ${ }^{3}$ Dit werd later bevestigd door Simpson met de verfijning dat de problemen van het vaatstelsel vooral emstigere langdurige problemen betroffen, waarvoor veelal verwijzing nodig was, terwijl die van het bewegingsapparaat veelal milde en voorbijgaande problemen waren. ${ }^{12}$

Andere beschreven fenomenen waarbij gezondheidsproblemen een rol spelen bij gebruik van 
slaapmiddelen, waren overgewicht en het wootkomen wan slaapstoomissen als gevolg van het slaapapnoesyndroom. 17,18

Vraag bij al deze bevindingen blijft in hoeverre er oorzakelijk verband is tussen het hebben van gezondheidsproblemen en het gebruik wan het psychofarmacon. Ook is de vraag of er dienaang. aande verschillen zijn tussen langdurig gebruikers, die deze middelen dagelijks gebruiken, en degenen die dit niet of minder vaak doen. Voor hulpverlening door de thuisarts is het bovendien belangrijk een inzicht te hebben in de actuele lichamelijke gezondheid van de (langdurig) gebruiker.

Hiervan witgaande stelden we ons de volgende vragen:

1. In hoeverre worden problemen met de eigen gezondheid door patiënten beschouwd als oorzaak van het gebruik van slaap-en kalmeringsmiddelen en in hoeverre bestaan er verschillen in de aard van deze gezondheidsproblemen tussen de diverse typen gebruikers?

2. Hoe is het gesteld met de lichamelijke gezondheid van de diverse typen gebruikers ten opzichte van niet-gebruikers?

\subsection{Methode}

\section{Algemeen}

Om inzicht te krijgen in de mening van de patiëntgebruiker ten aanzien van een mogelijk verband tussen gezondheidsproblemen en het gebruik van slaap- en kalmeringsmiddelen werd gebruik gematakt van een enquête, waarin patiënten vragen gesteld werden over het gebruik van deze middelen. De enquêtering vond plaats van december 1993 tot juni 1994 in 11 huisartsenpraktijken, warin 33 huisartsen werkzaam waren. De onderzoekspopulatie is geselecteerd uit de ingeschreven populatie van 30 jaar en ouder. De selectie van gebruikers vond plaats op twee manieren: een voorselectie door apothekers en een populatiesurvey. Er werd een controlegroep van niet-gebruikers geselecteerd, gematcht op basis van leeftijd en geslacht, telkens uit dezelfde praktijk. Demografische gegevens en psychosociale kenmerken zijn reeds beschreven in boofdstuk $10^{\circ}$

Om de lichamelijke gezondheid te inventariseren wan gebruikers van slaap-en kalmeringsmiddelen ten opzichte van niet-gebruikers werd gebruik gemaakt van het onderzoeksbestand van het RegistratieNet Huisartspraktijken (RNH) van de Universiteit Maastricht (UM). Dit geautomatiseerde bestand bestaat uit patiënt-achtergrondgegevens en probleemlijsten als een onderdeel van de medische verslaglegging in de huisartspraktijk. De probleemlijst van een patiènt is opgebouwd uit een of meer probleemregels. Een probleemregel is gedefinieerd als 
een omschrijuing van een voor de gezondheid relevant probleem of diagnose, langer dan 6 maanden durend, dan wel permanent of recidiverend van belang. Elke probleemregel is gecodeerd volgens de International Classification of Primary Care (ICPC). ${ }^{19-22}$ Het RNH bestand wordt beheend door het Medisch en Maatschappelijk Informatie Centrum (MEMIC).

\section{Procedure en meetinstrumenten}

Personen van 30 jaar en ouder ontvingen een postenquête, die vragen bevatte omtrent onder andere achtergrondvariabelen, enkele lichamelijke kenmerken, wragen naar verschijnselen van het slaap-apnoesyndroom en medicatiegebruik in thet jaar voorafgaand aan het verzenden van de enquête. Aan diegenen die in deze vragenlijst het gebruik van een slaap- en/of kalmeringsmiddel vermeldden, werd een tweede enquête gestuurd met vragen over de aard en omvang van dit medicamentgebruik, verdeeld in drie tijdvakken (periode vó́r 1 oktober "92, periode van 1 oktober ' 92 tot 1 oktober" 93 , periode vanaf 1 oktober' '93).

De selectie van patiënten vond plaats op twee manieren:

a) in negen praktijken werd door apothekers een woorselectie gemaakt van patiënt-gebruikers $(n=1724)$

b) in twee praktijken werd een populatiesurvey $(n=1265)$ uitgevoerd om op basis van aangegeven medicatiegebruik in de eerste enquête de gebruikers te selecteren. Controlepersonen werden op basis van leeftijd en geslacht per praktijk gematcht.

\section{Dataverwerking}

De antwoorden van de enquêtes werden met behulp van SPSS bewerkt en geanalyseerd. ${ }^{23}$ Omwille van eenduidigheid werden de klachten en diagnosen, gemeld door de patient in zijn enquête, gecodeerd met behulp wan de ICPC, dezelfde classificatielijst die ook door de huisartsen in de probleemlijsten wordt gebruikt; ${ }^{21}$ woor de medicamenten werd de groepsindeling gevolgd zoals ze in het farmacotherapeutisch kompas wordt aangegeven. ${ }^{24}$ De gebruikers van slaap- en/of kalmeringsmiddelen werden, op basis van de gegevens over het gebruik verdeeld in twee groepen: kortdurend en langdurig gebruik (langdurig is langer dan 3 maanden). Alleen voor de praktijken waar geen sellectie door apotheken plaats had gevonden, werden daartoe de medische dossiers van deze praktijken gebruikt. Langdurig gebruik werd nog onderverdeeld in: episodisch (meerdere episodes) en continu gebruik. Voor kortdurend gebruik werd de indeling in eenmalig en episodisch voor de verdere analyses achterwege gelaten omdat de subgroep episodisch gebruik slechts 18 personen betrof; de subgroep kortdurend-episodisch bleek ten opzichte van de subgroep eenmalig meer mannen te bevatten, maar er was geen verschil in leeftijdsverdeling en de top-3 van de gebruikte slaap-en/of kalmeringsmiddelen.

Op basis van deze indeling werden drie gebruikersgroepen onderscheiden: kortdurend gebrui- 
kers (KG), (tangdurig-) episodisch gebruikers (LEG) en (langdurig-) continu gebruikers (LCG). Ze werden onderling vergeleken voor zover ze problemen met eigen gezondheid als reden voor gebruik van het medicament hadden vermeld. Vergelijking met de niet-gebruikers (NG) vond plaats met behulp wan de probleemlijst in het huisartsdossier. Allereerst werd gekeken naar werschillen op het niveau van de ICPC-hoofdstukken. Daarna werd in betreffende hoofdstukken gezocht naar verschillen op diagnoseniveau of groepen diagnosen. Hierin werd zoveel mogelijk de systematiek gevolgd wan de ICPC-lijst. Bij herhaald voorkomen van eenzelfde diagnose (recidieven, episodes van actief en inactief zijn van het probleem) in de prob]eemlijst werd deze diagnose slechts éénmaal geteld.

\section{Statistische bewerking}

De data zijn per groep gepresenteerd door middel van aantallen, percentages of gemiddelden. Vanwege de matching op leeftijd en geslacht zijn deze twee variabelen in de vergelijkende analyses niet meegenomen.

In de vergelijking van de probleemlijsten van de drie gebruikersgroepen met die van de nietgebruikers werd in de bivariate analyse voor nominalle schalen de chi-kwadraat toets of de exacte toets van Fisher gebruikt, voor ordinale schalen de t-toets en/of de Mann-Whitney toets. Scores op de onderzochte variabelen werden als statistisch significant verschillend beschouwd als de p-waarde $<0,05$ was. Bij cen zeer gering aantal waarnemingen in de onderzoeksresultaten zijn toetsresultaten niet gepresenteerd.

Door middel van logistische regressie is nagegaan welke kenmerken in onderlinge relatie verband houden met verschillende vormen van gebruik. Hierbij is elke gebruikersgroep vergeleken met de niet-gebruikers. In deze analyse is door middel van stratificatie op leeftijd en geslacht rekening gehouden met de gematchte opzet van het onderzoek. De verkregen adds ratio's zijn vanwege de geringe populatiefrequenties te interpreteren als relatieve risico's. ${ }^{25}$

\subsection{Resultaten}

\section{Algemean}

Respons. 4583 Personen werden benaderd om mee te doen aan de postenquête. De respons op de eerste enquêtte was $55 \%$ op de tweede $71 \%$. Uiteindelijk resteerden 1588 personen voor de analyses, waarvan 883 controlepersonen en 705 gebruikers. (figuur I)

De uitval gedurende het onderzoek bedroeg in totaal 115 personen, (werhuisd/andere huisarts, overleden, slechte kwaliteit invulling, medicament niet gebriikt, recall probleem, gebruik buiten registratieperiode, niet in staat mee te doen, verkeerde leeftijdselectie, onbekend). 
Non-respons. De non-respons van de gebruikersgroep op de eerste enquête $(n=835)$ in de praktijken met voorselectie door apothekers bevatte meer ouderen ( $>70$ jaar) dan de respons $(p<0,05)$ en daaraan gecorreleerd ook meer mensen zonder partner als ook meer ziekenfondsverzekerden en laag opgeleiden. De groep controlepersonen van deze praktijken liet hetzelfde beeld zien. In de praktijken zonder voorselectie verschilde de non-respons op de eerste enquête $(n=494)$ qua leeftijd en geslacht niet. In de non-responsgroep van de tweede enquête, die alleen werd geanalyseerd woor de gebruikers van de praktijken met voorselectie, kwamen meer jongeren (30-39 jaar) voor, terwijl in de categorie 50-59 jaar minder personen te vinden waren dan in de responsgroep; qua geslacht was er geen verschil.

figuur 1

\section{onderzoekspopulatie, aantallen}

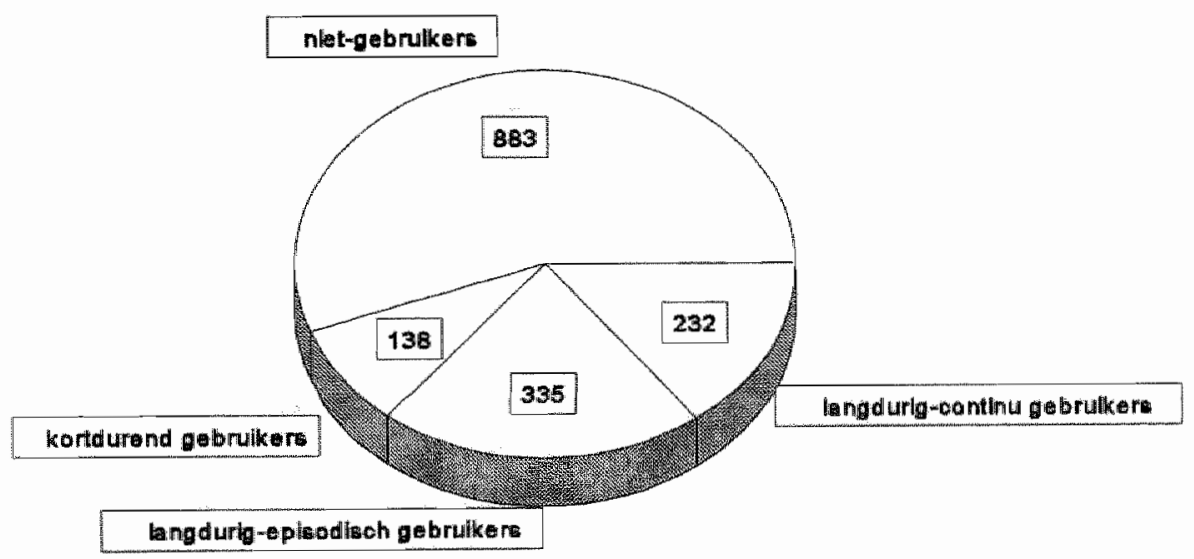

Problemen met de eigen gezondheid in relatie tot gebruik

De Klacht. Gebruikers van slaap en kalmeringsmiddelen hadden het meest klachten die te rubriceren waren onder nervositeit, spanning of angstgevoelens en slaapproblemen (hoofdstuk 8). Waar de gebruikers ten tijde van het onderzoek gezondheidsproblemen als oorzaak van het 
gebruik noemden, werden ook deze klachten het meest genoemd: bij de kortdurend gebruikers $61,3 \%$, bij de episodisch gebruikers $89,5 \%$ en bij de continu gebruikers $89,3 \%$.

Problemen met eigen gezondheid als oorzalk wan gebruik. Van de kortdurend gebruikers (KO) noemden 45,3\% problemen met eigen gezondheid (mede) oorzaak voor het gebruik, de episodisch gebruikers (LEG) $53,4 \%$; de continu gebruikers (LCG) deden dit in $61,4 \%$ van de gevallen, significant meer dan de kortdurend gebruikers $(p<0,05)$. De drie meest genoemde gezondheidsprobliemen vonden we bij de kortdurend gebruikers vooral op gebied van het bewegingsapparaat, maag-darmkanaal, hart-vaatstelsel; bij de langdurig gebruikers op gebied van het bewegingsapparaat, hart-vaatstelsel, psychische stoornissen (tabel 1 ).

tabel 1. De drie gezondheidsproblemen (gecodeerd volgens de code van ICPC-hoofdstukken) die door de drie gebruikersgroepen het eerst genoend werden als oorzaak van de klacht waarvoor het slaap- en/of kalmeringsmiddell gebruikt werd. Percentages.

\begin{tabular}{|c|c|c|c|c|c|c|c|c|c|}
\hline \multirow{2}{*}{$\begin{array}{l}\text { ICPC } \\
\text { tractus (1) }\end{array}$} & \multicolumn{2}{|c|}{$\begin{array}{l}\text { kortdurend } \\
\text { gebruikers } \\
n=62\end{array}$} & \multirow[b]{2}{*}{$\mathrm{GPP}^{(2)}$} & \multicolumn{3}{|c|}{$\begin{array}{l}\text { langdurig-episodisch } \\
\text { gebruikers } \\
n=173\end{array}$} & \multicolumn{2}{|c|}{$\begin{array}{l}\text { langdurig-contimu } \\
\text { gebruikers } \\
n=134\end{array}$} & \multirow{2}{*}{$\mathrm{GP}^{(2)}$} \\
\hline & GP1 & $\mathrm{GP} 2$ & & GP1 & GP2 & $\mathrm{GP}^{(2)}$ & GP1 & GP2 & \\
\hline$\underset{\mathbf{B}}{\mathbf{A}}$ & 1,4 & 2,1 & - & 2,7 & 0,6 & - & $\begin{array}{l}3,3 \\
1,0\end{array}$ & 1,4 & 0,5 \\
\hline D & 8,7 & 1.4 & 1.4 & 3,6 & 3,9 & 0,9 & $\begin{array}{l}0,0 \\
3,8\end{array}$ & 2,9 & 1,4 \\
\hline $\mathbf{F}$ & $\therefore$ & $\therefore$ & 0,7 & $\therefore$ & $\ldots$ & 0,3 & 0,5 & - & - \\
\hline $\mathbf{H}$ & 0,7 & 0,7 & 07 & 0,6 & - & 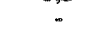 & 0,5 & - & - \\
\hline $\mathbf{K}$ & 5.7 & 3,6 & 0,7 & 9,9 & 3,3 & & 15,1 & 5,1 & 1,4 \\
\hline $\mathbf{L}$ & 13,7 & 3,6 & 0,7 & 12.4 & 8.1 & 1,8 & 13,5 & 13,3 & 3,0 \\
\hline$\underset{p}{N}$ & 2,1 & 0,7 & 0,7 & 5,8 & 1,5 & 0,9 & 4,9 & 2,3 & 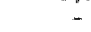 \\
\hline$p$ & $2, \mathbb{1}$ & 1,4 & 0,7 & 7,6 & 3,6 & - & 8,3 & 3,8 & - \\
\hline $\mathbb{R}$ & 3,6 & 0,7 & 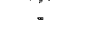 & 4,2 & 1,5 & - & 5,1 & 2,4 & - \\
\hline$\stackrel{S}{T}$ & 07 & 0,7 & & 0,3 & & & 0,5 & . & . \\
\hline U & 0.7 & $\begin{array}{l}0.7 \\
0.7\end{array}$ & 0,7 & $\begin{array}{l}0,6 \\
1,2\end{array}$ & 1,2 & $\begin{array}{l}0,6 \\
0,3\end{array}$ & $\begin{array}{l}2,8 \\
0,5\end{array}$ & $\begin{array}{l}1,0 \\
0,5\end{array}$ & 0.5 \\
\hline$w$ & & 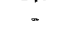 & & & & & & & \\
\hline 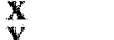 & 5,6 & - & 0,7 & 3,3 & 1.2 & 0,6 & 2,9 & 1,4 & - \\
\hline $\begin{array}{l}Y \\
z\end{array}$ & - & - & - & 0,6 & 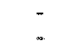 & : & 0,5 & 1,0 & 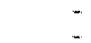 \\
\hline
\end{tabular}

(1) indeling $1 \mathrm{CPC}$ hoofdsmikken:

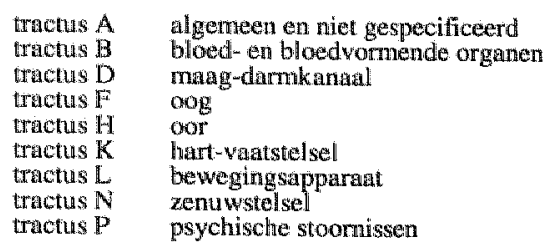

\begin{tabular}{|c|c|}
\hline triactus $R$ & luchtwegen \\
\hline tractus $S$ & huid en subutatan weefsel \\
\hline triptetis & endocrienc, metabole en voedirasziektes \\
\hline tractus: U & urinewegen \\
\hline tractus $\mathrm{A}^{2}$ & $\begin{array}{l}\text { zwangerschap, be walling, kramabed, anti- } \\
\text { conceptis }\end{array}$ \\
\hline tractus $X$ & geslachtsorganen en bonsten vrouw \\
\hline tractus $Y$ & geslachtsonganen en borsten man \\
\hline tratcus 2 & sociale problemem \\
\hline
\end{tabular}

(2) GP1-3: eerste, tweede en derde gezondheidsprobleem genoend als oorzaak voor gebruik

In tabel 2 staat een overzicht van de (eerstgenoemde) gezondheidsproblemen, voor zover ze gespecificeerd zijn weergegeven door de gebruikers. Wat betreft de top drie van de meest 
tabel 2. Subscores (gecomprimeerd) van het eerstgenoemde gezondheidsprobleem, waarwoor slaap- en/of kalmeringsmiddelen werden gebruikt door de drie gebruikersgroepen. Aantallen.

\begin{tabular}{|c|c|c|c|c|}
\hline $\begin{array}{l}\text { icpe } \\
\text { code }\end{array}$ & omschrijuing & $\begin{array}{l}\mathrm{KG}_{\mathrm{K}}^{*} \\
\mathrm{n}=62\end{array}$ & $\begin{array}{l}\mathrm{LEG}_{\mathrm{n}=173}^{*} \\
\end{array}$ & $\begin{array}{l}\mathrm{LCG} \\
\mathrm{n}=134\end{array}$ \\
\hline $\begin{array}{l}\text { D } \\
00 \\
01-29 \\
75 \\
82-87 \\
93 \\
94 \\
98 / 99\end{array}$ & $\begin{array}{l}\text { maag-darmstelsel (totaal) } \\
\text { niet gespecificeerd } \\
\text { klachten- } \\
\text { coloncarcinoom } \\
\text { ziektes mond/oesofagus/maag } \\
\text { IBS } \\
\text { chron. enteritis, M. Crohn } \\
\text { overige aandoeningen }\end{array}$ & $\begin{array}{l}(12) \\
1 \\
4 \\
1 \\
5 \\
- \\
j\end{array}$ & $\begin{array}{l}(12) \\
4 \\
3 \\
1 \\
3 \\
1 \\
- \\
-\end{array}$ & $\begin{array}{l}(8) \\
2 \\
- \\
\vdots \\
2 \\
2 \\
2 \\
2\end{array}$ \\
\hline $\begin{array}{l}\mathbb{K} \\
00 \\
01-29 \\
74-80 \\
86 \\
89-90 \\
91 / 94 / 95 / 99\end{array}$ & $\begin{array}{l}\text { hart-vaatstelsel (totaal) } \\
\text { niet gespecificeerd } \\
\text { klachten - } \\
\text { hartziektes: coronaria/ decomp./ritme } \\
\text { hypertensie } \\
\text { CVA/TIA } \\
\text { overige aandoeningen }\end{array}$ & $\begin{array}{l}(8) \\
3 \\
1 \\
3 \\
- \\
1 \\
1\end{array}$ & $\begin{array}{l}(33) \\
6 \\
5 \\
11 \\
4 \\
5 \\
2\end{array}$ & $\begin{array}{l}(32) \\
8 \\
2 \\
13 \\
3 \\
3 \\
3\end{array}$ \\
\hline $\begin{array}{l}1 \\
00 \\
01-29 \\
72-76 \\
83-86 \\
88 \\
89-91 \\
93 / 99\end{array}$ & $\begin{array}{l}\text { bewegingsapparaat (totaal) } \\
\text { niet gespecificeerd } \\
\text { klachten - } \\
\text { fracturen/letsels } \\
\text { WK-pathologie } \\
\text { rheumatoide arthritis } \\
\text { arthrose gewrichten } \\
\text { overige aandoeningen }\end{array}$ & $\begin{array}{l}(19) \\
13 \\
2 \\
2 \\
2 \\
2\end{array}$ & $\begin{array}{l}(39) \\
1 \\
24 \\
2 \\
4 \\
1 \\
7 \\
-\end{array}$ & $\begin{array}{l}(29) \\
15 \\
3 \\
4 \\
3 \\
2 \\
2\end{array}$ \\
\hline $\begin{array}{l}\mathbf{N} \\
00 \\
01-29 \\
73 \\
76 \\
87 \\
88 \\
89-90 \\
91 / 99 \\
\end{array}$ & $\begin{array}{l}\text { zenuwstelsel (totaal) } \\
\text { niet gespecificeerd } \\
\text { klachten - } \\
\text { infectie } \\
\text { neoplasma niet gespecificeerd } \\
\text { M. Parkinson } \\
\text { epilepsie } \\
\text { migraine, cluster haedache } \\
\text { overige aandoeningen }\end{array}$ & $\begin{array}{l}(3) \\
- \\
2 \\
\vdots \\
\vdots \\
\vdots \\
1 \\
-\end{array}$ & $\begin{array}{l}(19) \\
\overline{7} \\
1 \\
- \\
\overline{2} \\
8 \\
1\end{array}$ & $\begin{array}{l}(10) \\
- \\
4 \\
1 \\
2 \\
1 \\
1 \\
1\end{array}$ \\
\hline $\begin{array}{l}\text { P } \\
00 \\
01-06 \\
15 \\
73 \\
74 \\
75 \\
76 \\
78 \\
99\end{array}$ & $\begin{array}{l}\text { psychische stoornissen (total) } \\
\text { niet gespecificeerd } \\
\text { klachitem - } \\
\text { alcoholabusus } \\
\text { psychose } \\
\text { tobie/angststoomis } \\
\text { hysteriehypochondrie } \\
\text { depressie } \\
\text { neurathenie/surmenage } \\
\text { overige aandoeningen }\end{array}$ & $\begin{array}{l}\text { (3) } \\
3 \\
= \\
= \\
= \\
- \\
-\end{array}$ & $\begin{array}{c}(25) \\
1 \\
16 \\
- \\
1 \\
3 \\
1 \\
2 \\
1 \\
-\end{array}$ & $\begin{array}{l}(18) \\
9 \\
2 \\
- \\
4 \\
- \\
2 \\
1\end{array}$ \\
\hline $\begin{array}{l}\mathbf{R} \\
00 \\
01-29 \\
75 / 76 \\
96 \\
98 \\
99\end{array}$ & $\begin{array}{l}\text { luchtwegen (totaal) } \\
\text { niet gespecificeerd } \\
\text { klachiten- } \\
\text { infecties } \\
\text { asthma } \\
\text { hyperventilatie } \\
\text { overige aandoeningen }\end{array}$ & $\begin{array}{l}(5) \\
1 \\
- \\
3 \\
1 \\
- \\
-\end{array}$ & $\begin{array}{l}(14) \\
1 \\
2 \\
1 \\
6 \\
3 \\
1\end{array}$ & $\begin{array}{l}(11) \\
2 \\
1 \\
5 \\
3 \\
3\end{array}$ \\
\hline $\begin{array}{l}x \\
00 \\
01-29 \\
75-77 \\
79 \\
87 \\
99\end{array}$ & $\begin{array}{l}\text { vrouwelijke genitale stelsel (totaal) } \\
\text { niet gespecificeerd } \\
\text { klachten - } \\
\text { maligne neoplasmata } \\
\text { benigne mammatumor } \\
\text { vaginale prolaps } \\
\text { overige aandoeningen }\end{array}$ & $\begin{array}{l}(7) \\
\overline{3} \\
1 \\
1 \\
1 \\
2\end{array}$ & $\begin{array}{l}(11) \\
1 \\
5 \\
2 \\
5 \\
1 \\
2\end{array}$ & $\begin{array}{l}(6) \\
i \\
2 \\
j \\
2 \\
1\end{array}$ \\
\hline
\end{tabular}

* KG: kortdurend gebruikers LEG: langdurig-episodisch gebruikers LCG: langdurig-continu gebruikers 
genoemde gezondheidsproblemen konden we het volgende constateren: door alle drie de groepen werden problemen van het bewegingsapparaat veelal weergegeven in de vorm van klachten, vooral van nek en rug; de continu gebruikers noemden vaker een diagnose: met name diwerse vormen van arthrose en rheumatoïde arthritis. Problemen wan het hart-vaatstelsel werden door de drie groepen in een derde van de gevallen niet gespecificeerd weergegeven; voor zover wel gespecificeerd, werden hartaandoeningen het meest genoemd als oorzaak. Beide groepen langdurig gebruikers noemden ook hypertensie en CVA. Op het gebied van het maagdarmkanaal werden door de kordurend gebruikers het meest ziektes van mond/slokdarm/maag genoemd. Ongeveer $14 \%$ van gezondheidsproblemen werd door beide groepen langdurig gebruikers in de vorm van psychische stoornissen (klachten of diagnosen) benoemd.

\section{Gezondheidsproblemen van gebruilkers en niet-gebruikers.}

Medicamentgebruik in de loop van een jaar. Het aantal verschillende medicamenten dat volgens de patiënten gebruikt werd in één jaar, was in alle drie de gebruikersgroepen hoger dan in de controllegroep (kortdurend gebruikers gemiddeld 3, episodisch 4 , continu 4 en nietgebruikers gemiddeld $2 ; p<0,001)$. Met als uitgangspunt 5\% of meer verschil, werden ten opzichte van de controlegroep naast de middelen voor het zenuwstelsel door de kortdurend gebruikers vooral meer middelen voor de tractus digestivus, voor infectieziektes/parasitaire ziektes en analgetica gebruikt; door de episodisch gebruikers vooral meer middelen voor de tractus circulatorius, tractus digestivus en analgetica; door de continu gebruikers meer middelen voor bloed, tractus circulatorius, tractus digestivus en vitamines.

Quetelet-index en verschijnselen van het slaapapnoe-syndroom. De onderzochte groepen verschilden niet qua gewicht, weergegeven in de vorm van de Quetelet-index. Adlipositas (Q1s30) kwam zowel bij gebruikers als niet-gebruikers bij ongeveer $12 \%$ voor. De controlepersonen snurkten meer dan de gebruikers $(p<0,010)$. Bij de langdurig gebruikers kwam vaker een stokkende ademhaling voor $(p<0,005)$ en waren meer personen die schoppende bewew gingen maakten tjjdens de slaap $(p<0,0 / 0)$. De combinatie van adipositas en een of meer van de verschijnselen als snurken, stokkende ademhaling of schoppen in de slaap, $\mathrm{kwam}$ in de totale populatie in $6,6 \%$ van de gevallen voor. Bij de groep episodisch gebruikers kwam deze combinatio minder voor dan in de controlegroep $(p<0,05)$.

Probleemlistem. Alle probleemregels (actieve en inactieve) in de probleemlijsten werden op het niveau van de ICPC-hoofdstukken opgeteld en per onderzoeksgroep vergeleken. De verschillen zijn weergegeven in tabel 4. Van de op deze manier gevonden ICPC-hoofdstukken werd op diagnoseniveau gezocht naar significante verschillen met de controlegroep (tabel 5). Vergeleken met niet-gebruikers werden op diagnose-niveau bij alle drie de gebruikersgroepen 
meer probleemregels gevonden over iatrogene schade (vooral bijwerkingen van geneesmiddelen), en meer regels met klachten over het maagdarmkanaal en het bewegingsapparaat. Daarnaast hadden de kortdurend gebruikers meer probleemregels met klachten over de luchtwegen alsook de diagnosen tenniselleboog, acuut knieletsel en chronische infecties van tonsillen/adenoid. Bij de langdurig gebruikers vonden we aanmerkelijk meer probleemregels ten opzichte van niet-gebruikers: naast de al genoemde problemen met het maag-darmkanaal en het bewegingsapparaat betrof dit ook het hart-vaatstelsel, de luchtwegen, het zenuwstelsel en het vrouwelijk genitaal stelsel. Daarnaast betrof dit bij de episodisch gebruiker nog dootheid, overgewicht en stoornissen in het vetmetabolisme en bij de continu gebruikers tevens problemen met het endocriene stelsel en cataract.

tabel 4. Vergelijking van hoofdstuk-codes (zie toelichting tabel 1) van de problexmugels in de probleemlijsten van de niet-gebruikersgrop versus die van de gebruikersgroepen. Percentages, gemiddeld aantal problemen per tractus.

\begin{tabular}{|c|c|c|c|c|c|c|c|c|c|c|c|}
\hline \multirow{2}{*}{$\begin{array}{l}\text { ICPC } \\
\text { tractus }\end{array}$} & \multicolumn{2}{|c|}{$\begin{array}{l}\text { niet- } \\
\text { gebruikers NG } \\
(\mathrm{n}=88.3)^{\dagger}\end{array}$} & \multicolumn{3}{|c|}{$\begin{array}{l}\text { kortdurend } \\
\text { gebruikers } \mathrm{KG} \\
(\mathrm{n}=138)^{\mathrm{f}}\end{array}$} & \multicolumn{3}{|c|}{$\begin{array}{l}\text { langdurig-episodisch } \\
\text { gebruikers LEG } \\
(\mathrm{n}=335)^{\dagger}\end{array}$} & \multicolumn{3}{|c|}{$\begin{array}{l}\text { langdurig-continu } \\
\text { gebrulkers LCG } \\
(\mathrm{n}=232)\end{array}$} \\
\hline & 㮯 & mean & $\%$ & mean & $p^{7}$ & 蕰 & mean & $p^{\mp}$ & $\%$ & meass & $p^{7}$ \\
\hline A & 15,9 & 1,4 & 27,5 & 1,3 & *now & 29,6 & 1,3 & $* * * * *$ & 24,1 & 1,6 & $*$ \\
\hline $\mathrm{B}$ & 2,1 & 1,1 & 5,8 & 1,0 & $*$ & 3,9 & 1,0 & & 2,6 & 1,0 & \\
\hline D & 27,7 & 1,5 & 31,2 & 1,8 & & 46,0 & 1,8 & ****** & 49,6 & 1,9 & 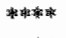 \\
\hline$F$ & 9,6 & 1,2 & 7,2 & 1,2 & & 12,5 & 1,3 & & 20,7 & 1,4 & 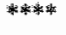 \\
\hline $\mathrm{H}$ & 7.7 & 1,2 & 8,7 & 1,4 & & 14,0 & 1,2 & 冰承 & 9,9 & 1,0 & \\
\hline $\mathbf{K}$ & 33,0 & 1,6 & 29,0 & 1,8 & & 41,8 & 1,9 & * & 54,3 & 2,0 & 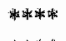 \\
\hline L & 43,3 & 1,7 & 52,9 & 1,9 & $*$ & 62,1 & 2,0 & 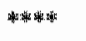 & 60,3 & 2,3 & 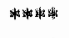 \\
\hline $\mathbb{N}$ & 13,4 & 1,2 & 19,6 & $1, \pi$ & & 25,1 & 1,2 & 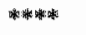 & 25,0 & 1,3 & $* * * * *$ \\
\hline$P$ & 13,4 & 1,2 & 25,4 & 1,4 & $* * * *$ & 40,3 & 1,5 & 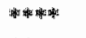 & 53,9 & 1,6 & 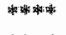 \\
\hline $\mathbf{R}$ & 22,8 & 1,3 & 34,1 & 1,4 & 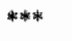 & 31,6 & 1.5 & * & 35,3 & 1.4 & * \\
\hline$s$ & 18.8 & 1,2 & 22,5 & 1,3 & & 20,1 & 1,2 & & 22,8 & 1.3 & \\
\hline $\mathrm{T}$ & 21,6 & 1,3 & 22,5 & 1,3 & & $288_{m} 7$ & 1,3 & & 40,1 & 1,3 & 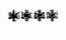 \\
\hline$U$ & 10,8 & 1,3 & 13,0 & 1,2 & & 15,8 & 1,2 & & 16,4 & 1,4 & \\
\hline w & 14,6 & 1,3 & 23,2 & 1,4 & $*$ & 17,0 & 1,5 & & 15,9 & 1,3 & \\
\hline$x$ & 26,7 & 1,3 & 30,4 & 1,3 & & 37,9 & 1,5 & W & 37,1 & 1,6 & ****at \\
\hline Y & 9,2 & 1,1 & 8.7 & 1,2 & & 7,7 & 1,2 & & 12,9 & 1,2 & \\
\hline$Z$ & 13,5 & 1,2 & 22,7 & 1,2 & * & 20,0 & 1,2 & * & 27,2 & 11,5 & 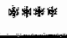 \\
\hline
\end{tabular}
† personen met lege probleemlijsten: NG $\mathrm{n}=116(13 \%), \mathrm{KG} \mathrm{n}=14(10 \%)$ LEG $\mathrm{n}=12(4 \%)$ en LCG $\mathrm{n}=5$ (2\%). of \pm p wararde volgens MW-toets * $p<0,05 * * 0<0,01 * * * 0<0,005 * * * p_{0}<0,001$ mean: gemiddeld aantal problemen (actief en inacticf) met dezelfde hooldstuk-code van personen met cen of meer malen dexe hoofdstuk-code in de probleemilijst. 
tabel 5. Vergelijking van probleemalijsten van niet-gebruikers (NG) met gebruikers (kortdurend gebruikers KG, langdurig-episodisch gebruikers LEG en langdurig-continu gebnuikers LCG). Alleen codes of groepen van codes die onderling significant werschilden zijn in de tabel opgenomen. Percentages.

\begin{tabular}{|c|c|c|c|c|c|c|c|c|}
\hline tractus & diagnose ICPC-Code** & $\begin{array}{c}\text { NG } \\
n=883 \\
\%\end{array}$ & $\begin{array}{c}K G \\
n=138 \\
0\end{array}$ & $p$ & $\begin{array}{c}\mathbb{L E G} \\
\mathbf{n}=335 \\
\%\end{array}$ & $p$ & $\begin{array}{c}\text { LCG } \\
\mathrm{n}=232 \\
\text { of }\end{array}$ & $P$ 洋 \\
\hline w. A & klacht A01-29 & 3,6 & & - & 6,6 &, 026 & & \\
\hline & Jatrogene schade $A 84,85,87,89$ & 10,6 & 18,8 & .005 & 20,9 &, 000 & 16,4 & .016 \\
\hline \multirow[t]{7}{*}{ tr. D } & Klacht Dol-29 & 5,2 & 10,1 &, 022 & 13,7 &, 000 & 13,4 &, 000 \\
\hline & inffecties D70,72,73 & 0,8 & - & $=$ & 3,6 &, 000 & & \\
\hline & ulcus duodeni D85 & 1,9 & - & - & 3,9 & .049 & 5,6 & .002 \\
\hline & ulcus ventriculi D86 & 1,5 & $=$ & - & 3,3 &, 042 & & \\
\hline & appendicitins D88 & 3,7 & - & - & 7,8 &, 003 & 7,8 &, 003 \\
\hline & intable bowell syndroom 093 & 1,8 & . & - & 3,9 & .034 & 6,0 &, 000 \\
\hline & overige aandoeningen D99 & 5,8 & $=$ & . & 9,9 & .012 & 14,2 &, 000 \\
\hline $\operatorname{tr}, \mathbb{F}$ & & 3.3 & - & - & & $=$ & 8,2 &, 001 \\
\hline tr. $\mathrm{H}$ & doofheid $\mathrm{H}-184,85_{n} 86$ & 3,7 & - & * & 8,1 &, 002 & - & \\
\hline \multirow{6}{*}{ tr. $\mathrm{K}$} & coronair problemen $K 74,75,76$ & 7,5 & - & - & $\approx$ & - & 19,0 &, 000 \\
\hline & decompensatio cordis $K 77$ & 0,5 & - & - & - & * & 1.7 & .041 \\
\hline & hartritmestoornissen $K 78,79,80$ & 2,7 & - & - & $\therefore$ & - & 9,5 &, 000 \\
\hline & harklepafwijkingen $\mathrm{K} 83$ & 0,0 & 1,4 & .018 & 0,9 & .021 & 3,9 & .000 \\
\hline & verhoogde bloeddruk. $K 85,86,87$ & 13,3 & & - & 18,8 & .015 & 237 &, 000 \\
\hline & CVA K $89 ; 90$ & 2,2 & & - & 5.4 & .003 & 5,6 &, 005 \\
\hline \multirow[t]{7}{*}{$\operatorname{tr} . \mathbf{L}$} & Kllacht $101-29$ & 13,8 & 21,7 &, 015 & 26,3 & .000 & 23.7 &, 000 \\
\hline & fracturen $1072-76$ & 7,1 & $*$ & & 10,7 & .039 & 13,8 &, 001 \\
\hline & syndronen cervicale WK L83 & 4,6 & - & - & - & & 8,6 &, 018 \\
\hline & werworven afwijkingen WK L $L 85$ & 2.4 & - & - & - & & 5,2 & .025 \\
\hline & arthrose (excl WK) L89,90,91 & 7,2 & $=$ & - & 12,5 & .003 & - & - \\
\hline & tenniselleboog L93 & 1,2 & 5,8 & .002 & - & & " & - \\
\hline & acturt knieletsel L96 & 2,2 & 6,5 & .008 & 0 & - & $\therefore$ & - \\
\hline \multirow[t]{5}{*}{ tr. $N$} & klacht NO1-29 & 4,9 & - & - & 8,4 & ${ }_{8} 020$ & 11,2 & ,000 \\
\hline & schedelletsel $N 79,80$ & 0,6 & - & - & - & & 2,6 & .014 \\
\hline & epilepsie N88 & 0,6 & - & - & - & - & 2,6 & .014 \\
\hline & migraine $N 89,90$ & 2,9 & - & - & $\therefore$ & - & 0,0 & .003 \\
\hline & perifere neuropathie N94 & 0,6 & $\therefore$ & - & 3,0 &, 002 & 3,9 & .000 \\
\hline \multirow[t]{5}{*}{ tr. R } & klacht ROI-29 & 2,8 & 8,0 & .005 & 6,0 & .010 & & \\
\hline & neoplasmata $R 84,85,86$ & 0,3 & $-i 6$ & & 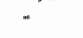 & & 3,0 & .001 \\
\hline & chron, inf tonsillen/adenoid $\mathbb{R} 90$ & 2,4 & 11,6 & ,000 & - & - & -3 & \\
\hline & $\begin{array}{l}\text { chronische bronchitis R91 } \\
\text { asthima R96 }\end{array}$ & $\begin{array}{l}1,5 \\
2,9\end{array}$ & - & $\ldots$ & 6.3 & 007 & 6,4 & .058 \\
\hline & hyperventilatie R98 & 2,3 & - & $=$ & 7,8 & .000 & 9,5 & , 000 \\
\hline \multirow[t]{6}{*}{ tr. $\mathrm{T}$} & struma T81 & 2,4 & - & - & - & & 5,6 & 011 \\
\hline & overgewicht $(\mathrm{BMI}>30)$ T82 & 5,2 & " & - & 8,4 & .040 & 8,6 & .050 \\
\hline & overgewicht $(\mathrm{BMI}<30)$ T83 & 3,4 & - & - & - & & 9,1 &, 000 \\
\hline & hyperthyroidie T85 & 2,3 & - & - & “ & - & 6,0 & 0003 \\
\hline & aholisme Toz & 4,8 & $\infty$ & . & $=$ & & 9,5 & .006 \\
\hline & $\begin{array}{l}\text { stoornis vernetabolisme } \mathrm{T} 93 \\
\text { k }\end{array}$ & 3,7 & - & - & 6,6 &, 034 & 7,3 &, 019 \\
\hline \multirow{3}{*}{ ta. $x$} & $\begin{array}{l}\text { klacht W01-29 } \\
\text { neoplesimata } \times 75-81\end{array}$ & $\begin{array}{l}7,7 \\
9,9\end{array}$ & 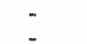 & - & 12,8 & .00 & - & \\
\hline & utero vagingale prolaps $\times 87$ & $\begin{array}{l}9,9 \\
3,5\end{array}$ & 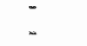 & 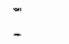 & $\begin{array}{r}17,9 \\
6,3\end{array}$ & 00 & 6,9 & 002 \\
\hline & overige anudoeningen $\times 99$ & 3,7 & - & $:$ & 6,9 & .020 & 8,6 & .002 \\
\hline
\end{tabular}

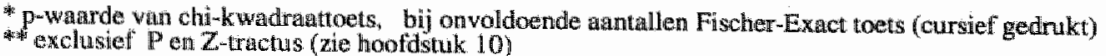


tabel 6. Het gereduceerde model van de logistische regressie-analyse voor de drie gebnikersgroepen: KG (kortdurend gebnuik) LEG (langdurig-episodisch gebniik) LCG (langdurig-continu gebruik). De afhankelijke variabele is "gebruik van slaap-en/of kalmeringsmiddel"

\begin{tabular}{|c|c|c|c|c|c|c|}
\hline & \multicolumn{2}{|l|}{$\mathrm{KG}$} & \multicolumn{2}{|l|}{ LEG } & \multicolumn{2}{|c|}{$\mathrm{LCG}$} \\
\hline & $\mathrm{OR}$ & $95 \%$ BI & $\mathrm{OR}$ & $95 \%$ BI & OR & $95 \%$ BI \\
\hline aantal soorten medicamenten/jaar & 1,21 & $1,11-1,31$ & 1,29 & $1,21-1,38$ & 1,28 & $1,19-1,38$ \\
\hline aantal actieve problemen in probleern-lijst & 1,32 & $1,22-1,43$ & 1.16 & $1,09-1,23$ & 1.25 & $1,16-1,34$ \\
\hline $\begin{array}{l}\text { aantal inactieve problemen in probl-lijst } \\
\text { antal probleemregels uit: }\end{array}$ & - & - & 0,92 & $0,86-0,99$ & - & - \\
\hline hoofdstuk A & - & - & * & - & 0.73 & $0,57 \times 0,94$ \\
\hline hoofdstuk D & - & - & 1.23 & $1,03-1,47$ & - & $\cdot$ \\
\hline hoofdstuk P & - & - & 2,40 & $1,87-3,07$ & 2,96 & $2,27-3,88$ \\
\hline hoofdistuk X & - & - & 1,23 & $1,00-1,51$ & $\therefore$ & - \\
\hline
\end{tabular}

OR: odds ratio ${ }^{(1,3)}$ BI: $95 \%$ betrouwbaarheids interwal ${ }^{(2)}$

noot:

$\mathrm{OR}=\left(\right.$ odds $\left.\left.\left._{\mathrm{v}}\right):\left(\operatorname{odds}_{0}\right)=\llbracket \mathrm{p}_{\mathrm{v}} /\left(1-\mathrm{p}_{\mathrm{v}}\right)\right]: \llbracket \mathrm{p}_{0} /\left(1-\mathrm{p}_{0}\right)\right]$

odds: de kans gebruiker te zijn gedeeld door de kans geen gebrniker te zijn bij aanwezigheid van de variabele $\mathrm{e}_{\mathrm{v}}$ odd $s_{0}$ : de kans gebruiker te zijn gedeeld door de kans geen gebruiker te zijn bij afwezigheid van variabele Pv: de kans gebruiker te zijn gegeven de aanwezigheid van een variabele $1-p_{v}$ : de kams geen gebruiker te zijn gegeven de aanwezigheid van een variabele.

$\mathrm{P}_{0}$ : de kans gebruiker te zijn gegeven de afwezigheid van een wariabele

1 - $\mathrm{P}_{0}$ : de kans geen gebruiker te zijn gegeven de afwezigheid van een variabele

noot 2: $95 \%$ BI: $95 \%$ betrouwbaarheidsinterval rond de Odds Ratio is berekend middels:

$$
\mathrm{e}^{[\mathrm{B}-(1,96 \times \mathrm{SE})]}<\mathrm{OR}<\mathrm{e}^{[\mathrm{B}+(1,96 \times \mathrm{SEE})]}
$$

noot 3: Odds Ratio (OR) = Relatief Risico (RR) gezien de geringe populatiefrequentie. ${ }^{26}$

Met de variabelen (aantal medicamenten per jaar, aantal aktieve en inaktieve problemen in de probleemlijst en de ICPC-hooldstukken) die in de bivariate analyse significant verschilden, werd een regressie-analyse uitgevoerd, waarbij de afhankelijke variabele "gebruik wan een slaap-en/of kalmeringsmiddel" was (tabel 6). In het gereduceerde model van de regressie bleken de volgende wariabelen samenhang te vertonen met een of meer vormen van gebruik:

- voor álle groepen gebruikers: een groter aantal soorten gebruikte medicamenten in het onderzoeksjaar en een groter aantal actieve probleemregels in de probleemlijst;

- voor beide groepen langdurig gebruikers bleek geestelijke gezondheid, in de probleemlijst vastgelegd als het voorkomen van psychische stoomissen, het sterkst geassocieerd te zijn met gebruik van slaap- en/of kalmeringsmiddelen.

- alleen voor episodisch gebruikers bleek daarnaast het voorkomen van probleemregels van maag-darmkanal en vrouwelijke genitale stelsel samenhang te vertonen met gebruik. 


\subsection{Beschouwing}

In 11 huisartspraktijken werd door middel van een postenquête en een analyse van probleemlijsten in een steekproef van gebruikers van slaap-en kalmeringsmiddelen en een op leeftijd en geslacht gematchte controlegroep gezocht naar een mogelijk verband tussen problemen met gezondheid en de verschillende vormen van gebruik en naar eventuele verschillen in gezondheidskenmerken tussen gebruikers en niet-gebruikers.

Ongeveer de helft van de gebruikers noemde problemen met eigen gezondheid (mede) de oorzaak van de klachten waarvoor een slaap-en/of kalmeringsmiddel werd gebruikt; de continu gebruikers meer dan de kortdurend gebruikers. De kortdurend gebruikers noemden vooral problemen met het bewegingsapparaat en het maagdarmkanaal, de langdurig gebruikers problemen met het bewegingsapparaat en het hart-vaatstelsel. De problemen kwamen vooral tot uiting in de worm van klachten als gevoelens van angst/nervositeit/gespannenheid en slaapstoomissen.

Wat betreft de lichamelijke gezondheid werden ten opzichte van de niet-gebruikers bij de drie groepen gebruikers de volgende verschillen gevonden: bij de gebruikersgroepen bleek het algemeen medicamentgebruik groter te zijn en bevatten hun probleemlijsten meer actieve probleemregels. De aard wan deze probleemregels, voor zover het somatische problemen betroffen, verschilden niet, met uitzondering van die van de episodisch gebruikers bij wie meer probleemregels voorkwamen op het gebied van het maag-darmkanaal en het vrouwelijk genitaal stelsel; voor zover het psychosociale problemen betroffen bleek voor beide groepen langdurig gebruikers het hebben van probleemregels wit het ICPC-hoofdstuk psychische stoornissen het sterkst geassocicerd te zijn met gebnuik.

Het onderzoek is retrospectief van aard en daarmee voor een deel afhankelijk van de herinnering van de gebruiker. De recall bias kon beperkt blijven doordat de gebruikers reeds te voren bekend waren door middel van de selectie van apothekers. Omdat de controlegroep gematcht is op geslacht en leeftijd is een vergelijking van geslachts-en leeftijdsverdeling niet zinvol. Uit de non-respons analyse mag geconcludeerd worden dat ouderen minder hebben deelgenomen aan het enquête-onderzoek en dat daarmee de beide groepen langdurig gebruikers in de bevolking nog groter zullen zijn dan door ons gevonden is; beide groepen langdurig gebruikers waren immers ouder dan kortdurend gebruikers (zie hoofdstuk 10).

De ICPC die de mogelijkheid biedt om naast diagnosen ook klachten te registreren sluit daarmee het meest aan bij het huisartsgeneeskundig denken. Echter het feit dat bij het classificeren van klachten en/of problemen in deze lijst veelal uitgegaan wordt van categorieèn brengt beperkingen met zich mee. Ook het feit dat per diagnose de aantallen soms erg klein waren, maakte noodzakelijk op categorieën en zelfs op niveau van ICPC-hoofdstukken te analyseren. Een ander classificatieprobleem was dat het in medische en farmaceutische termen verwerken 
en gedetailleerd coderen van door patiènt aangereikte informatie over medicatie en gezondheidsproblemen soms niet goed mogelijk was.

Het door de gebruikers aangegeven causale verband tussen problemen met eigen gezondheid en diverse vormen van gebruik van slaap- en kalmeringsmiddelen, van $45 \%$ bij kortdurend gebruik oplopend naar $61 \%$ bij continu gebruik, lijkt de reeds eerder gevonden relatie tussen gezondheidsproblemen en langdurig gebruik te bevestigen. ${ }^{13,18}$ Hierbij moet in het midden gelaten worden of de ziekte op zich, dan well symptomen van een ziekte of verwerking van een ziekte reden woor het gebruik waren. Enkele van de door artsen aangegeven somatische indicaties (lage rugklachten en myalgie, hypertensie) die $V_{\text {an }}$ der $\mathrm{Waals}^{14}$ vond bij langdurig gebruik, lijken aan te sluiten bij de door onze onderzoekspopulatie aangegeven gezondheidsproblemen als oorzaak voor gebruik, met name problemen van bewegingsapparaat en hartvaatstelsel.

De in de literatuur gevonden verschillen tussen langdurig gebruikers en niet-gebruikers in de zin van het hebben van een slechtere gezondheidsstatus ${ }^{2,3,4,5}$ (meer gedetailleerd weergegeven in de zin van het hebben van meer problemen op gebied van het bewegingsapparaat, hartvaatstelsel, huid of maag-darmkanaal. $3,9,12,13$ ) of het hebben van meer klachten en meer ziektegevoel $^{11}$ worden weerspiegeld in de door ons gevonden verschillen, waarbij we onderscheid maakten in episodisch en continu gebruik. Als we de omvang van probleemlijsten beschouwen als een afspiegeling van de gezondheidsstatus (met name door een groter alantal actieve problemen) dan is daaruit op te maken dat deze voor de gebruiker minder goed is. Bij de multivariate analyse bleek een gedeelte van de gezondheidskenmerken weergegeven in de probleemlijsten weg te vallen, waarschijnlijk mede omdat ze gerelateerd waren aan de oudere leeftijd van de groep.

Bij beide groepen langdurig gebnikers kwamen in hun probleemlijst meer fracturen voor. $\mathrm{Bij}$ de continu gebruikers was dit voor alle typen fracturen meer dan bij niet-gebruikers en dus niet beperkt tot heupfracturen, die in de literatuur beschreven zijn als mogelijk gevolg van langdurig gebruik van benzodiazepinen. ${ }^{26}$ Het feit dat bij de analyse van de probleemlijsten geen rekening gehouden is met de periode dat het slaap-en/of kalmeringsmiddel gebruikt is, maakt het leggen van een causale relatie tussen al deze fracturen en het gebruik van slaap- en kalmeringsmiddelen niet mogelijk.

Het vóórkomen van de combinatie overgewicht $(\mathrm{QI}>30)$ en éen of meer van de drie andere onderzochte risicofactoren ${ }^{16}$ voor het slaapapnoe-syndroom was bij gebruikers niet groter dan bij niet-gebruikers (gemiddeld ruim 6\%); bij de episodisch gebruikers was het zelfs lager. Kennelijk is op dit risico toch geselecteerd door de huisartsen. Immers een gedeelte van de onderzoekspopulatie zal mogelijk lijden aan een slaapapneu-syndroorn en dientengevolge 
slaapklachten hebben. Dit zal echter een klein deel betreffen als we rekening houden met een prevalentie van nog geen $0,5 \%$, gevonden door Knuistingh Neven in zijn onderzoek naar het voorkomen van het slaapapineu-syndroom in de buisartspraktijk ${ }^{17}$

Opvallend frequent waren bij alle groepen gebruikers de vermeldingen in de probleemlijsten van bijwerkingen van geneesmiddelen. Dit is waarschijnlijk het gevolg wan het gebruik van een grotere hoeveelheid andere medicamenten, een kenmerk van de gebruikers van slaap- en kalmeringsmiddelen, ook reeds 20 jaar geleden aangetoond door Uhlenhuth ${ }^{2}$.

Uit de gegewens van dit deelonderzoek kunnen de volgende conclusies getrokken worden:

- Patiënt-gebruikers noemen vaak gezondheidsproblemen (vooral op gebied van het bewegingsapparaat en het hart-vaatstelsel) (mede) als oorzaak voor het gebruik van slaapen/of kalmeringsmiddelen, de continu gebruikers het meest. De huisarts en in mindere mate de specialist zal deze patiẻnten vaker zien en zich bij het voordoen van psychische stoornissen moeten afvragen in hoeverre lichamelijke klachten op genoemde probleemgebieden of het verwerken van deze problemen, hieraan debet zijn. Adequate behandeling zal mogelijke slaapstoornissen of klachten van angst/spanning, de door gebruikers meest genoemde psychische stoomissen, moeten voorkomen; indien besloten wordt om deze klachten te behandelen met slaap of kalmeringsmiddelen, zal een strikte bewaking moeten voorkomen dat deze middelen inadequaat lang gebruikt (gaan) worden.

- Op basis van de probleemlijstanalyse werd slechts een beperkt aantal lichamelijke kenmerken van gebruikers van slaap- en kalmeringsmiddelen gevonden. In dit opzicht geven gezondheidsproblemen de huisarts weinig houvast voor een risico-inschatting voor langdurig gebruik; andere kenmerken zoals de omvang van de probleemlijst en het gebruik van veel medicamenten kunnen de huisarts in dit opzicht wel behulpzaam zijn en een signaal zijn voor waakzaamheid bij prescriptie van slaap-en/of kalmeringsmiddelen.

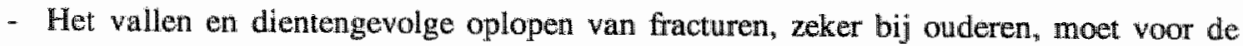
huisarts een signaal zijn on te kijken naar de toedracht van het ongeval. Het gebruik van slaap-en/of kalmeringsmiddelen is een mogelijke oorzaak van vallen en zal in de analyse van het ongeval betrokken moeten worden. Uiteraard is het adequal voorschrijven van deze middelen te beschouwen als preventie van dit soort accidenten.

- De huisarts heeft met zijn probleemlijstregistratie en de eventueel daarin vermelde psychische stoornissen een instrument ter beschikking dat hem, bij het vórkomen van deze stoornissen, signalen kan geven extra waakzaam te zijn bij het voorschrijven van slaap- en/of kalmeringsmiddelen.

Problemen met hart-vaatstelsel en bewegingsapparaat worden door gebruikers van slaap- en 
kalmeringsmiddelen het meest genoemd als oorzaak voor gebruik van slaap en kalmeringsmiddelen. Het ligt woor de hand dat de eerstgenoemde problemen meer te relateren zijn aan verwerkingsproblematiek. Nader onderzoek naar de specifieke hulpvraag bij deze twee categorieèn is nodig om adequaat om te kunnen gaan met de hulpvraag.

Gezondheidsproblemen op het gebied van het maag-darmkanaal en het vrouwelijk genitale stellsel kwamen wooral voor bij langdurig-episodisch gebruikers. Vraag is in hoeverre in de ogen van de huisarts een causaal verband bestaat tussen deze aandoeningen, eventueel zelfs andere gezondheidsproblemen, en het gebruik van slaap- en kalmeringsmiddelen. Hiervoor is nader onderzoek gewenst.

Longitudinaal onderzoek in de eerstelijn naar het vórkomen van bijwerkingen van slaap-en kalmeringsmiddelen (onder andere invloed op coördinatie/reaktiesnelheid, vallen, sufheid, mentale veranderingen) in relatie tot diverse vormen van gebruik is noodzakelijk. De resultaten hiervan kunnen de huisarts ondersteunen in zijn adviezen omtrent het adequaat gebruik van deze middelen.

Het hebben van problemen met de eigen gezondheid is voor patiènten een reden de huisarts te bezoeken. Effecten van lichamelijke problemen kunnen resulteren in psychische stoornissen. zoals onder andere angst, spanning, depressiviteit en slaapstoornissen, waarvoor de patiënt hulp vraagt. Het analyseren van de hulpvraag omtrent deze klachten, die door de patiënt in relatie gebracht worden met somatische problemen, is de eerste belangrijke stap in de hulpverlening, óok om het adequaat gebruik van slaap-en kalmeringsmiddelen te bevorderen. 


\section{Dankbetuiging}

Een woord van dank ajn we verschuldigd aan het Praeventiefonds, dat ons onderzoeksproject "chronisch psychofar" macngebruik in de eerste lijn" (projectn. 28-2186) tinanciel ondersteunde. Voor hun inzet bij dit onderzoek gaat onze dank ook wil naar onze research-assistentes Monique Latour en Karin Aretz, evenals naar de deelnemende artsen on hun assistentes van gezondheidscentra "Hoensbroek' te Hoensbroek, Withuis te Venlo en dr. $v$. Kleef te Mastricht. Thuisartsempraktijken 'medisch centrum Putgraat te Landgraat, Voerendaal' te Voerendaal, KaiserVeldhuizen te Eygelshoven, Soomers te Kerkrade en Govater-Leclencq te Stein, huisartspralktijken Guldemond te Ubachsberg, Van dier Ploeg te Kerkmide en Zwietering te Maastricht. 


\section{Literatuur}

1 Mellinger GD, Balter MB, Mannheimer DI, Cisin IH, Parry HI. Psychic distress, life crisis and use of psychotherapeutic medications. Arch Gen Psychiatry 1978; 35: 1045-52.

2 Uhlenhuth EH, Balter MB, Lipman RS. Mimor tranquillizers. Clinical correlates of use in an urban population. Arclu Gen Psychiatry 1978; 35: 650-5.

3 Mellinger GD, Bulter MB, Whenhuth EH. Prevalence and comelates of long tem regular use of anxiolytics. JAMA 1984; 251:375-9

4. Wells KB, Kamberg C, et all. Health status, sociodemografic actors and the use of prescribed psychotropic drugs. Medical Care 1985; 23: 1295-1306

5 Bljenberg-Ruis B, Garretsen HFL, Schuuman JH, Verdonk ALT. Het gebruik wan silap- en kalmeringsmiddelen. Een secundaire analyse van een Rotterdams onderzoek. T Soc Gezondheidsz 1986; 64:491-7

6. Salinsky JV, Dore CJ. Characteristics of long tem benzodiazepine users in general practice. I R Coll Gen Pract 1987; 202-4

7 Dumbar GC. Morgan DD, Perera KMH. The concurnent use of alcohol, cigarettes and caffeine in british benzodiazepine users as measured by a general population survey. Br J Addiction 1988; 83:689-94.

8 Catalan J, Gath D, et all. General practice patients on long term psychotropic dnugs. Br J Psychiatry 1988; 152: $399-405$

9 Gene-Badia J, Blay-Pueyo $\mathbb{C}_{\sharp}$ Soler-Vila M. Risk factors in the use of benzodiazepines, Fram Pract 198,5 : $283-8$

10 Dunbar GC, Perera MH. Jenmer FA. Patterns of benzodiazepine use in Great Brittain as measured by general population survey. Br J Psychiatry 1989; 155:836-41

11 Astiton H, Golding JF. Tranquillizers: prevalence, predictors and possible consequences. Data from a large United Kingdom survey. Br J Addict 1989; 84: 541-6.

12 Simpson $\mathrm{RJ}$, Power $\mathrm{KG}$, all. Controlled comparison of characteristics of long tem benzodiazepine users in general practice. Br J Gen Pract 1990; 40:22-6

13 Lagro-Janssen T, Liberton IJW. Profielen wan regelmatige gebruikers van benzodiazepinen in een huisartspraktijk. Ned Tijdschr Geneeskd 1993; 137: 1969-73

14 Van der Waals $F W$, Mohrs J, Foets M. Sex differences among recipients of benzodiazepines in Dutch general practice Br Med J 1993; 307: 363-7

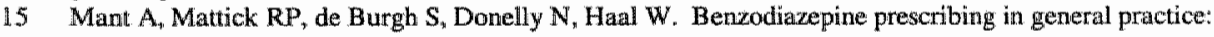
dispelling some myths. Fam Pract 1995; 12(1): 37-43.

16 Van Keimpema ARI, De Vries N, Visscher F. Het apnoesyndroom bij wolwassenen. Ned. Tijdschr Geneeskd $1990 ; 134(18): 895-9$

17 Knuistingh Neven A. Het slaapapneusyndroom in de huisartspraktijk. Dissertatie februari 1996 , Rijksuniversiteil Leiden. ISBN 90-5166-487-7

18 Vissers FHA, Knotnerus IA, Van der Grinten RF, Van der Horst FGEM. Langdurig gebruik wan slatap en kalmeringsmiddelen in een huisartspraktijk. Huisarts Wet $1993 ; 36(12): 405-8$

19 Metsemakers JFM, Hoppener P, Krotnerus JA, Kocken RJ, Limonard CBG. Computerized healh information in the Netherlands: a registration network of family practices. Brit I Gen Pract 1992; 42: 1026.

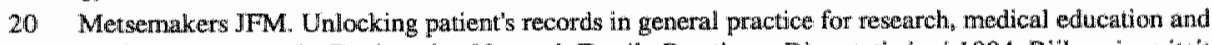
quality assurance: the Registration Network Family Practices. Dissertwie jumi 1994, Rijksuniversiteit Limburg. ISBN $90-5170-279-5$.

21 Lamberts H, Wood M. ICPC, International Classification of Primary Care. Oxford university press, New York: 1987. ISBN 0-19-261633*1.

22. Anonymus. 1 CHPPC-2 defined (inclusion criteria for the use of the nubrics of the International Classification of Health Problems in Primary Carej. Oxford University Press, 1983.

23 Anonymus. GLLM. Groningse lijst langdurige moeilikheden. In Omel J. Het Gromingse eerstelijnsprojekt: opzet en aanpak fintern rapport] Groningen: Rijksumiversiteit Groningen, afdeling Sociale: Psychuatrie $_{w} 1985$

24 Nonusis MJ. SPSS, Professional Statistics. SPSS incorporation. Michighan, Chicago, Illimois 1999, release 6.0. ISBN 0-13-178831-0.

25 Ziekenfondsrad. Firmacotherapentisch Kompas. Amstel veen, 1997 
26 Schouten HJA Klinische statustiek. Een praktische inleiding in methoulologie en analyse. Houten: Bohn. Stafles Van Loghum 1995. 1SBN 90-313-1968-6

27 Herings RMC, Stricker BHC, De Boer A, Bikker A, Sturmans F. Fernurfracturen, vallen en het gebruik van benzodiazepinetn: dosering betlangrijker dam halfwatardetijd. Ned Tujdschhr Farmacotherappie 1995; 1 : $2-9$ 
Hoofdstuk 12

\section{Benzodiazepinegebruik in de huisartspraktijk. Waarom laten we het (niet) zo ?}

Een exploratief onderzoek

Dit hoofdstuk is geaccepteerd voor publicatie in Huisarts en Wetenschap als:

Gubbels THCM, Vissers FHJA, Beusmans GHMI, Kester ADH, Crebolder HFJM. Benzodiazepinegebruik in de huisartspraknijk. Waarom laten we het (niet) zo? Een exploratief onderzoek. 


\section{Abstract}

Objective: to describe the number and characteristics of long-term benzodiazepine-users in general practice, who according to the GP should stop using the drug and with whom he would discuss it; and what are his reasons if not.

Design: descriptive study

Setting: four academic general practices $(\mathrm{N}=17.600)$

Method: ten participating GPs answered questionnaires about a random sample of 295 long. term benzodiazepine-users.

Results: the sample of long-term users had similar characteristics as mentioned in the literature. Compared to the total general practice population there were more women and more elderly people; the level of education was lower. The sample contained more people who were insured by the sick fund, more widowed and single people and more people living in a home for elderly people.

The GPs considered that for $43 \%$ of the sample it was indicated to stop using the benzodiazepines, but for $70 \%$ of this group he thought stopping was not feasiblle.

According to the GPs $11 \%$ of the long-term users were might be able to stop using. Predictive factors for bringing up the subject of stopping were 'duration of taking benzodiazepines' (using $<1$ year, OR=9,3; $\mathrm{p}<0.001$ ) and 'marital status' (divorced people $\mathrm{OR}=8,5 ; \mathrm{p}<0.001$ )

Conclusion: once a person has become a long-term user of benzodiazepines, the GP takes less initiative to discuss the reduction of this use.

Key words: benzodiazepines, stopping, view of the GP, general practice. 


\subsection{Inleiding}

Het benzodiazepinegebruik in de huisartspraktijk vormde een van onderwerpen van de Klinische Patiẻntbesprekingen in academische praktijken. Aan de hand van casuitstiek werden een aantal probleemsituaties geschetst rond het langdurig gebruik van slaap-en kalmeringsmiddelen (benzodiazepinen) zoals de herhaal-/baliereceptuur, de indicatiestelling, de hoge satisfactiegraad van de gebruikers ${ }^{2}$ en strategieën van stoppen van langdurig gebruik ${ }^{3}$ besproken.

Het motiveren tot en daadwerkelijk stoppen van langdurig gebruik en de begeleiding daarbij werden door de deelnemende huisartsen een moeizaam gebeuren geacht. In de discussie bleek dat zij inschatten dat het bij een aanzienlijk aantal langdurig gebruikers niet zinvol was het gebruik van benzodiazepinen aan de orde te stellen; naast somatische en psychiatrische als ook psychosociale redenen was volgens hen in het merendeel van de gevallen bij de voorschrijwend huisarts een vorm van acceptatie ontstaan: "er is een balans bereikt, de patiënt lijkt zich te kumnen handhaven dankzij de benzodiazepine en de huisarts accepteert dit." Moeten we ons zoveel zorgen maken om de bestaande groep langdurig gebruikers of zouden we er niet wakker van hoeven te liggen, zoals Lagro-Janssen in haar redactioneel commentaar stelt? ${ }^{4}$

Er werden aangaande selectiecriteria van huisartsen om wel of niet over te gaan tot individuele interventie bij langdurig gebruik in de literatuur geen gegevens gevonden.

Aan het eind van de bespreking resteerden wolgende vragen:

bij welke langdurig gebruikers van benzodiazepinen vindt de huisarts het aangewezen om stoppen/reductie te gaan bespreken, bij wie niet en waarom niet? Welke achtergrondvariaben hebben deze patiënten? Welke acties werden door de deelnemende artsen binnen een jaar na inventarisatie ondernomen?

\subsection{Methode}

Door vier Maastrichtse academische praktijken (qua huisartsbezetting 7 FTE, met een populatie van 17600 patiënten) werden de naburige apotheken verzocht een uitdraai te maken van afgeleverde benzodiazepinerecepten aan patiënten van betrokken praktijken over een periode van drie maanden (1 augustus tot 1 november 1996). 
Hieruit deze uitdraai werden de langdurig gebruikers geselecteerd. Langdurig gebruik werd gedefinieed als 2 of meer recepten in 3 maanden. Van drie praktijken werd uit het geselecteerde langdurig gebruikersbestand at random een steekproef genomen (40 personen per arts/nompraktijk); van ến praktijk werd wanwege de beperkte omvang de totale apotheekwitdraai voor het onderzoek gebruikt. De huisartsen werd gevraagd om over elke langdurig gebruiker (per benzodiazepine) een vragenlijst in te vullen. Deze lijst bevatte naast leeftijd, geslacht en achtergrondvariabelen (verzekering, burgerlijke staat, woonverband en opleiding) van de patiënt, algemene vragen ower het benzodiazepinegebruik (o.a. start van gebruik en de daarbij horende klacht en/of oorzaak van de klacht) en specifieke vragen over het onderwerp stoppen, c.q. reduceren. Voor zover de deelnemende artsen dit nodig achtten, werden bij de invulling van de vragenlijsten de dossiers van patiënten nageslagen..

Door de eigen huisarts is van iedere gebruiker aangegeven of deze al dan niet een potentiële stopper is, die hij zou gaan benaderen om het stoppen dan wel reduceren van het gebruik ter sprake te brenegen. In deze zin is het begrip potentiële stopper in de tekst gebruikt.

Bij gebruik van meerdere benzodiazepinen in de onderzoeksperiode werd voor de analyses uitgegaan van het middel waarvan het grootste aantal eenheden in die periode was afgeleverd. De diagnostische reden(ene) (klacht of diagnose) waarvoor het middel gebruikt werd en de indicatiestelling werden gecodeerd met behulp van de International Classification of Primary Care (ICPC). ${ }^{5}$ De gegevens werden geanonymiseerd opgeslagen in een computerbestand en statistisch bewerkt met behulp van SPSS. $^{6}$

Verschillen werden significant beschouwd als de $\mathrm{p}$-waarde $<0,05$ was. De multivariate analyse werd voor significante variabelen uitgevoerd middels een achterwaarts stapsgewijze logistische regressie. ${ }^{7}$ In deze analyse werden afzonderlijk variabelen getoetst met de likelihood ratio chikwadraattoets.

Drie van de vier deelnemende praktijken maken deel uit van het RegistratieNetwerk Huisartspraktijken (RNH) van de Universiteit Maastricht (UM), een netwerk dat een geautomatiseerd bestand levert van patient-achtergrondvariabelen en probleemlijsten van de medische verslaglegging. " De populatie-opbouw naar leeftijd en geslacht van deze drie praktijken was niet verschillend van het totale RNH-bestand. In verband met deze vergelijking werd verondersteld 
dat de praktijk (3700 patiënten) die geen onderdeel was van het RNH niet wezenlijk verschilde van de andere praktijken in populatie-opbouw.

\subsection{Resultaten}

De geselecteende groep gebruikers.

Aantallen. Door apotheken werden in totaal 548 gebruikers geselecteerd, waaruit een steekproef $(\mathrm{n}=295)$ genomen werd.

Gebruik. De deelnemende artsen waren in $96 \%$ van de gevallen op de hoogte van het gebruik. Volgens hen gebruikte $62 \%$ het middel langer dan 3 jaar. De duur van het gebruik was hen bij $22 \%$ van de gevallen niet bekend. Er werd in de onderzoeksperiode door $24 \%$ van de gebruikers meer dan én middel gebruikt. De groep gebruikers die in de onderzoeksperiode meer dan eén benzodiazepine gebruikt had $(\mathrm{n}=70)$, verschilde ten opzichte van de andere gebruikers niet qua leeftijd, geslacht, verzekering, burgerlijke staat, woonverband, opleiding en praktijk. Wel kwamen in deze groep meer mensen voor die het middel korter dan 1 jaar gebruikten $(p<0,005)$ en meer personen die meer dan een diagnostische reden voor gebruik hadden $(p<0,001)$.

Achtergrondvariabelen. Tabel 1 geeft een overzicht van de achtergrondvariabelen. In vergelijking met de RNH-populatie kwamen in de steekproef meer vrouwen voor en was de gemiddelde leeftijd hoger; er kwamen met name meer weduwen/weduwnaren voor; eveneens verschilde het woonverband: er waren meer allieenstaanden, meer echtparen en de groep, die in een verzorgingshuis woont, was groter; de onderzoekspopulatie bevatte meer ziekenfondsverzekerden en meer laag opgeleiden.

Reden voor gebruik. De diagnostische reden(en) (klacht en/of diagnose) waarvoor het middel gebruikt werd, werd door de huisarts voor 95\% ondergebracht in het ICPC-hoofdstuk van de psychische stoornissen (P): in 47\% van de gevallen angst/gespannenheid/nervositeit (P01) en in 45\% slapeloosheid (P06). Volgens de huisartsen waren bij $4 \%$ de diagnostische reden(en) een lichamelijke stoornis en bij $1 \%$ een sociaaal probleem.

Oorzaak van de reden woor gebruik. Bij 175 personen (59\%) werd geen oorzaak vermeld, inclusief 52 personen waarvan de huisarts expliciet aangaf dat hem de oorzaak niet bekend was. Voor zover ( $n=120$ personen) door de huisartsen een of meerdere oorzaken werden genoemd, ging het in $47 \%$ van de vermelde oorzaken om psychische stoomissen (ICPC- 
hoofdstuk P), in 25\% om lichamelijke stoornissen (ICPC-hoofdstukken $A, B, D, K, L, N, R, T, X$ ) en in $28 \%$ om sociale problemen (ICPC-hoofdstuk Z).

llabel 1. Achtergrondwariabelen wan de langdurig gebruikers en de praktijk-populatie (RNH). Verschilleru tussent totale steekproef en RNH-populatie per wariathele getoets middels chi-kwadraatroets Percentages.

\begin{tabular}{|c|c|c|c|c|}
\hline variabele & $\begin{array}{l}\text { steekproef } \\
\text { langdurig } \\
\text { gebruikers } \\
\text { n=295 } \\
\%\end{array}$ & $\begin{array}{l}\text { (steekproef } \\
\text { langdurigge- } \\
\text { bruikers) } \\
(\mathrm{n}=65) \\
(\%)\end{array}$ & $\begin{array}{l}\text { praktijk } \\
\text { (RNH) } \\
\text { populatie } \\
\text { n=9208 } \\
\% \%\end{array}$ & $\mathrm{p}$ \\
\hline $\begin{array}{c}\text { geslacht: wrous } \\
\text { man }\end{array}$ & $\begin{array}{l}74 \\
26\end{array}$ & $(75)$ & $\begin{array}{l}53 \\
47\end{array}$ & $<0,01$ \\
\hline $\begin{array}{l}\text { leefuigd } \\
25-44 \text { jaar } \\
45-64 \text { jaar } \\
65-74 \text { jaar } \\
75 \text { jaar en ouder }\end{array}$ & $\begin{array}{l}12 \\
36 \\
24 \\
28\end{array}$ & $\begin{array}{l}(11) \\
(43) \\
(22)\end{array}$ & $\begin{array}{r}45 \\
33 \\
13 \\
9\end{array}$ & $<0,01$ \\
\hline $\begin{array}{l}\text { burgerlijke staat: } \\
\text { gehuwd } \\
\text { ongehuwd } \\
\text { samenwonend } \\
\text { weduwe(naar) } \\
\text { gescheiden }\end{array}$ & $\begin{array}{r}52 \\
11 \\
2 \\
28 \\
7\end{array}$ & $\begin{array}{r}(53) \\
(11) \\
(3) \\
(25) \\
(8)\end{array}$ & $\begin{array}{r}59 \\
23 \\
5 \\
8 \\
5\end{array}$ & $<0,01$ \\
\hline $\begin{array}{l}\text { woonverband: } \\
\text { alleenstarand } \\
\text { gezin } \\
\text { echtpdiar } \\
\text { verzorgingshuis } \\
\text { overig }\end{array}$ & $\begin{array}{l}32 \\
19 \\
36 \\
13 \\
-\end{array}$ & $\begin{array}{r}(40) \\
(31) \\
(36) \\
-\end{array}$ & $\begin{array}{r}22 \\
62 \\
14 \\
1 \\
1\end{array}$ & $<0,001$ \\
\hline $\begin{array}{l}\text { opleiding: } \\
\text { lager onderwijs } \\
\text { middelbatur onderwijs } \\
\text { hoger onderwijs }\end{array}$ & $\begin{array}{r}69 \\
25 \\
6\end{array}$ & $\begin{array}{r}58) \\
(35) \\
(7)\end{array}$ & $\begin{array}{l}43 \\
41 \\
16\end{array}$ & $<0,01$ \\
\hline $\begin{array}{l}\text { verzekering: } \\
\text { ziekenfonds } \\
\text { particulier }\end{array}$ & $\begin{array}{l}82 \\
18\end{array}$ & $\begin{array}{l}(80) \\
(20)\end{array}$ & $\begin{array}{l}62 \\
38\end{array}$ & $<0,01$ \\
\hline
\end{tabular}

* de steekproel van langdurig gebruikers uit de praktijk die geten lid was van het RNH.

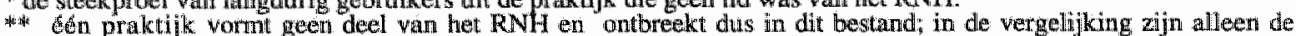
personten die 25 jan of ouder tijn mesgenomer.

\section{Stoppen of wiet?}

In een stroomdiagram konden de huisartsen hun opvattingen stapsgewijs aangeven met betrekking tot stoppen of reduceren van het benzodiazepinegebruik figuur $1 \%$. Bij $57 \%$ van de gevallen werd stoppen niet aangewezen geacht. De redenen daarvoor waren vooral somatische of psychiatrische (38\%) en psychosociale (30\%) indicaties. Van de resterende 128 personen achtten zij het stoppen in $70 \%$ van de gevallen niet haalbaar: bij bijna de helft van deze patienten zou proberen te stoppen hun draagkracht te boven gaan. Tot slot resteerden nog $3 \mathbb{1}$ 
personen $(11 \%)$, die door de artsen gerekend werden tot potentiële stoppers en die zij zouden willen benaderen om het gebruik van het psychofarmacon ter discussie te stellen. Bij 14 personen zouden ze dat op korte termijn doen en bij 17 in een latere fase, dat wil zeggen afwachten totdat patiënt op spreekuur zou komen. Van de 264 niet-stoppers was de spreiding over de vier praktijken $17-33 \%$. De verschillen waren niet significant.

Tiguuir 1. Stroomdiagram met betrekking tot het initiatief van de huisarts het stoppen of reducenen van benzodiazepine-gebruik met langdurig gebnikers te gaan bespreken. $(n=295)$. Aantallen, percentages.

is stoppen aangewezen?

is stoppen haalbaar?

hebt 1 er de moelte yoor ower?
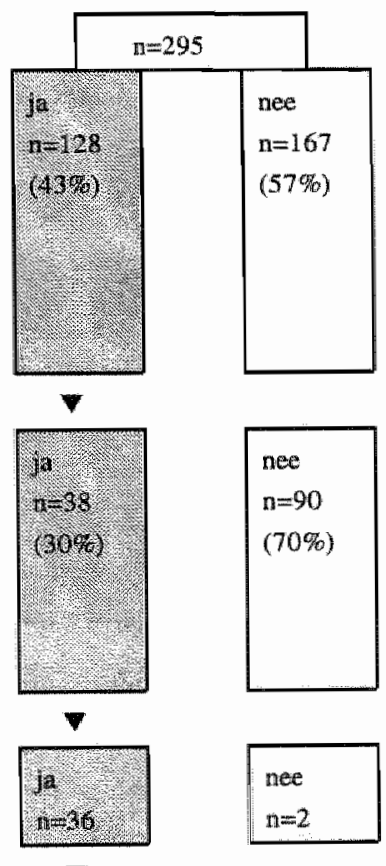

want:

-somatisch, psychilatrisch geindiceerd* (38\%)

-psychosociaal geindiceerd * $(30 \%)$

-gebnikt weinig (13\%)

-combinatie $(7 \%)$

-al gestopt (2sio)

-anders $(10 \%)$

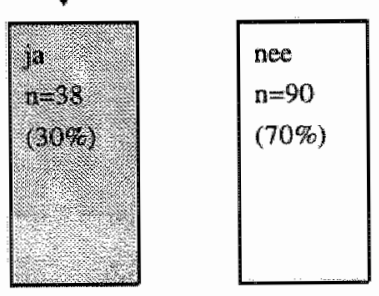

Want:

-gaat draagkracht patient te boven (47\%)

- vorige stoppoging mislukt (13\%)

-eerder verzoek niet opgevolgd (9\%)

-combinatie van voorgaande (24\%)

-anders (7\%)

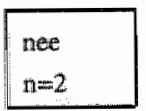

Want:

te veel moeite (100\%)

galat u patięut vragen te stop-

pen?

want:

te veel stress, ellders in behandeling

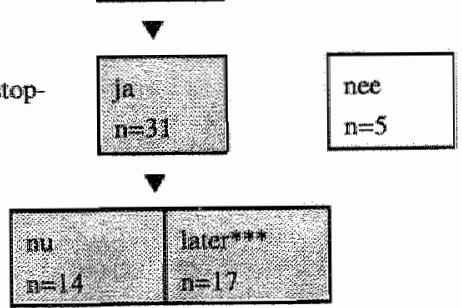

* sometisch, psychiatrisch geindiceerd: d. w. z wegens en ziekte of aamdoening; bijvoorbeeld: epilepsic, spierspas-

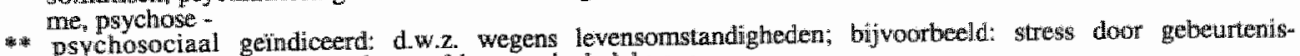
sen/onstandigheden, levensfase problemen, alcoholabusus

* later; d.w. $z$ bij gelegenheid als een volgend consult zich voordaer 
tabel 2. Vergelijhimg var (wolgens de thisartsen) potentiele stoppers en niet-stoppers. Aantallen, percentages. Verochillen getoetst middels chi-kwadratatoets.

\begin{tabular}{|c|c|c|c|}
\hline variabele & $\begin{array}{l}\text { potentiele } \\
\text { stoppers } \\
(\mathrm{n}=31 \mathrm{1}) \\
\quad \% \\
\end{array}$ & $\begin{array}{c}\text { potentiele } \\
\text { niet-stoppers } \\
(\mathrm{n}=264) \\
96\end{array}$ & $\mathrm{p}^{*}$ \\
\hline $\begin{array}{l}\text { gestachit: wrouws } \\
\text { man }\end{array}$ & $\begin{array}{l}77 \\
23\end{array}$ & $\begin{array}{l}74 \\
26\end{array}$ & ns \\
\hline $\begin{array}{ll}\text { leefiyd: } & 25-44 \text { jatar } \\
& 45-64 \text { juar } \\
& 65-74 \text { juar } \\
& 75 \text { jaar en ouder }\end{array}$ & $\begin{array}{l}23 \\
47 \\
20 \\
10\end{array}$ & $\begin{array}{l}11 \\
35 \\
24 \\
30\end{array}$ & $<0,05$ \\
\hline $\begin{aligned} & \text { burgerlijke stacat: } \text { gehuwd } \\
& \text { ongehuwd } \\
& \text { samenwonend } \\
& \text { weduwe/-naar } \\
& \text { gescheiden }\end{aligned}$ & $\begin{array}{l}58 \\
10 \\
10 \\
10 \\
22\end{array}$ & $\begin{array}{r}51 \\
12 \\
2 \\
30 \\
5\end{array}$ & $<0,01$ \\
\hline $\begin{aligned} & \text { woonverband: } \text { alleenstadind } \\
& \text { gezin } \\
& \text { echtpast } \\
& \text { werzorgingshuis }\end{aligned}$ & $\begin{array}{l}24 \\
24 \\
38 \\
14\end{array}$ & $\begin{array}{l}33 \\
18 \\
35 \\
14\end{array}$ & ns \\
\hline $\begin{array}{c}\text { opleiding: Jager onderwijs } \\
\text { middelbaar onderwijs } \\
\text { hoger onderwijs }\end{array}$ & $\begin{array}{r}71 \\
25 \\
4\end{array}$ & $\begin{array}{r}69 \\
25 \\
6\end{array}$ & ns \\
\hline $\begin{array}{c}\text { verzekering: ziekenfonds } \\
\text { particulier }\end{array}$ & $\begin{array}{l}87 \\
13\end{array}$ & $\begin{array}{l}82 \\
18\end{array}$ & $\mathrm{~ns}$ \\
\hline arts niet op de hoogte wan gebruik & 13 & 3 & $<0,05$ \\
\hline start in onderzoeksperiode & 17 & 6 & $<0,05$ \\
\hline $\begin{array}{l}\text { duur van gebruik in jaren: } \\
<1 \\
1-2 \\
2-3 \\
>3\end{array}$ & $\begin{array}{r}46 \\
15 \\
4 \\
35\end{array}$ & $\begin{array}{r}12 \\
13 \\
9 \\
66\end{array}$ & $<0,01$ \\
\hline $\begin{array}{l}\text { (diagnostische) reden poor gebraik } \\
\text { psychische stoornisen } \\
\text { lichamelijke stoornissen } \\
\text { socule problemen }\end{array}$ & $\begin{array}{r}97 \\
3 \\
-1\end{array}$ & $\begin{array}{r}95 \\
4 \\
1\end{array}$ & $\mathrm{~ns}$ \\
\hline
\end{tabular}

* p-ivaride van chi-kwadratat toets.

\section{Bivariate analyse potentiële stoppers en niet-stoppers (tabel 2).}

In de groep gebruikers, die de huisarts wilde motiveren te stoppen (potentiele stoppers) kwamen meer jongeren (25-64jr) voor, meer gescheiden mensen en minder weduwen of weduwnaren. Het betrof wooral de mensen die het gebruik startten in de onderzoeksperiode en/of korter dan Én jaar het psychofarmacon gebruikten. Geslacht, woonverband, opleiding, verzekering en diagnostische reden voor gebruik verschilden niet significant. 
De groep gebruikers die meer dan één benzodiazepine gebnikte in de onderzoeksperiode verschilde ten opzichte van de andere gebruikers niet qua kans om tot de groep potentiele stoppers te horen.

\section{Multiwariate analyse potentièle stoppers en niet-stoppers.}

Van de steekproef konden alle personen in de regressie-analyse geïncludeerd worden. In cen logistische regressie (met als afhankelijke variabele wel/niet een gesprek aangaan over stoppen) werden alle variabelen opgenomen die in de bivariate analyse significant waren. Nadat vervolgens in dit regressiemodel de niet-significante variabelen werden weggelaten bleven twee variabellen over: de burgerlijke staat $(p<0,001)$ en duur wan het gebruik $(p<0,001)$. Wat betreft de variabele 'duur van gebruik' bleken vooral personen die het middel korter dan eern jaar gebruikten ten opzichte wan degenen die langer dan drie jaar gebruikten een significante kans te hebben om tot de potentiële stoppers te behoren (OR=9,3;p<0,00I). Voor de "burgerlijke staat' gold dit vooral voor de categorie gescheiden mensen ten opzichte van de gehuwden $(\mathrm{OR}=8,5 ; p<0,001)$

Tot slot:

Bij inventarisatie na 1 jaar bleken de huisartsen bij 13 (42\%) van de 31 potentiële stoppers het stoppen besproken te hebben (niet meer in praktijk $n=3$, overleden $n=2$ ). Door 10 van deze 13 personen werd het gebruik daadwerkelijk gestopt.

\subsection{Beschouwing}

In vier huisartspraktijken ( $N=17600$ patiẻnten) werden de huisartsen geënquêteerd ontrent hun overwegingen om bij langdurig benzodiazepine-gebruikers al of niet aan een stopadvies te geven en of zij betrokken patiënten hiertoe wilden benaderen. Van een steekproef langdurig gebruikers ( $n=295$ ) bleken de huisartsen bij $11 \%$ het zinvol te achten het gebruik ter discussie te stellem; slechts bij $3 \%$ bleek na een jaar dit ook daadwerkelijk uitgevoerd te zijn.

De groep potentiële stoppers was ten opzichte van de niet-stoppers jonger, bevatte meer gescheiden personen en minder weduwen/weduwnaren, men startte het gebruik veelal in de onderzoeksperiode of had een gebruiksduur korter dan een jaar. Uit de multivariate analyse bleek de kans dat een van de huisartsen zijn/haar langdurig gebruiker zou benaderen om het gebruik ter discussie te stellen bepaald werd door de gebruiksduur (gebruik korter dan een jaar) en burgerlijke staat (gescheiden). 
Het onderzoek vond plaats in vier academische huisartspraktijken. In de introducerende besprekingen werd de aanpak wan langdurig gebruik door alle artsen als een probleem ervaren. Het feit dat op de vragenlijst gebruik en middel vermeld werden, wormde voor de huisarts mogelijk een bias ten aanzien van de vragen over het op de hoogte zijn van het gebruik en de aard van de klacht waarwoor het middel gebruikt werd.

Het weergeven van de diagnostische reden (klacht/diagnose) én oorzaak ervan bleek niet altijd consequent te gebeuren; met name als bij de reden voor gebruik een diagnose werd genoemd, werd het aangeven wan een oorzaak vaak achterwege gelaten. Tevens werd de reden voor gebruik voomamelijk symptoomgericht weergegeven. Door dit feit en door het veelal ontbreken van de oorzalak van de reden voor het gebruik maakten het onmogelijk op diagnoseniveau een gedetailleerd beeld te schetsen omtrent het voorkomen van psychische/psychiatrische stoomissen en sociale problemen in de onderzochte groep langdurig gebruikers. Methodologische kanttekeningen ten aanzien wan de opzet van dit onderzoek zijn voorts het ontbreken van een controlegroep waarbij geen interventie plaatsvindt en onvoldoende blindering van de artsen.

De onderzochte groep langdurig gebruikers van deze praktijken had een aantal kenmerken die we in de literatuur ook terugvinden, namelijk het overwertegenwoordigd zijn van het vrouwelijk geslacht, een hogere leeftijd en een lagere opleiding. ${ }^{9-14}$

Het feit dat slechts $11 \%$ van de steekproef als potentiële stopper gezien werd door de deelnemende huisartsen en dat daarvan na eén jaar minder dan de helft feitelijk benaderd werd, geeft aan dat langdurig gebruik in de ogen van deze huisartsen een gegeven is en niet leidt tot een actieve opstelling. De vraag blijft natuurlijk of de patiënt-gebruikers, die niet geselecteerd zijn door deze huisartsen, dezelfde mening zijn toegedaan. Gegevens wit de literatuur lijken het antwoord op deze vraag te bevestigen; immers hun tevredenheid omtrent het effect van de gebruikte middelen is groot en bijwerkingen worden nauwelijks ervaren. Ook wordt door hen in thet merendeel van de gevallen aangegeven dat ze niet het gevoel hebben (gehad) te moeten stoppen. ${ }^{2,12,13}$

Op basis van dit oriénterend onderzoek concluderen we dat, als het op het initiatief van de huisartsen aankomt om langdurig gebruikers van benzodiazepinen individueel te benaderen, dit waarschijnlijk maar beperkt resultaat zal hebben op grond van de door de huisarts beoordeelde indicatiestelling en beperkte haalbaarheid. Het benaderen van deze gebruikers op groepsniveau is waarschijnlijk doelmatiger. Het verstrekken van een informatieve brief aan álle langdurig gebrükers reduceert volgens de literatuur het gebruik voor 25 tot 30 procent. ${ }^{15,16}$ 
Dit onderzoek maakt níet duidelijk welke diagnostische criteria de huisarts dient te hanteren ten aanzien van de indicatie voor continuering van gebruik. Hertoe dient nader onderzoek plaats te vinden met een aangepaste onderzoeksopzet en een hierop gerichte vraagstelling.

Het feit dat begelleiding van stoppogingen door de participerende huisartsen als moeizaam ervaren werd en dat interventiestudies in de eerste lijn een beperkt resultaat te zien geven voor diverse methoden van anpak ${ }^{3}$ pleit voor nader onderzoek naar interventiemethodes die de huisarts mogelijkheden bieden stoppogingen beter te kunnen begeleiden.

\section{Darkbetuiging}

Met dark woor de inzet van de participenende huisartsen en hun assistentes van de gezondheidscentra Heer de Hofhoek, van Kleef en huisartspraktijk Zwietering, als ook de apothekers Rümkes, Schissler-w.Hees, Straver, Van Thoor en Willems allen te Maastricht. 


\section{Literatuur}

De Kock CA, Crebolder HFJM, Beusmans GMHI, Gielen-wan Steenbergen S. Patientibesprekmgen in academieche praktijken. Opzet en een eerste inventarisatie. Medisch Contact 1997; 52: 106:-3

Vissers FHJA, Jongbloet AJ, Knotmerus JA, Wan der Grinten RF, Van der Horst FGEM. Benzodiazepinen: de gebruiker en zijn hwisarts. Bijwerkingen, szisfactie, afhankelijkheid en stoppen gezien door de bril van de gebuiker en zijn huisarts. Huisarts Wet 1998; 41(7);329-34

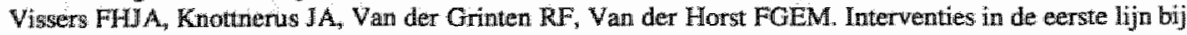
langdurig gebruik van benzodiazepinen. Een literatuuronderzoek. Huisarts Wet 1997; 40(6):244-7 Lagro-janssen T. Benzodiazepinen en de gemoedsnust van de huisarts [Commentaar]. Huisarts Wet 1993; $36(12) \div 402-4$

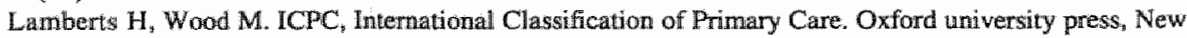
York, 1987 . ISBN 0-19-261633-11.

6 Norusis MU. SPSS, Professional Statistics. SPSS incorporation. Michighan, Chicago, Illinois. 1993, releawe 6.0. ISBN 0-13-178831-0.

Schouten H. Klinische statistek. Een praktische unleiding in methodologie en analyse. Houten: Bohn Sit.afleu Wan Loghum. 1995. ISBN 90-313-1968-6

Mietsemakers JFM, Hóppener P, Knottnerus JA, Kocken RIJ, Limonard CBG. Computerized health informatiou in the Netherlands; a registration network of family practices. Brit J Gen Praci 1992; 42: 1026 ,

Blijenberg-Ruis $B_{8}$ Garmetsen HFL, Schuurman JH, Verdonk ALT. Het gebruik van slaap-en kalmeringsmiddelen. Een secundaire analyse van een Rotterdams onderzoek. T Soc Gezondheidsz 1986; 64: 491-7 Salinsky JV, Dore CJ. Characteristics of long-term benzodiaxepine users in general practice. I R Coll Gen Pract 1987; 202-4

11. Ashton H, Golding JF. Tranquillizers: prevalence, predictars and possible consequences. Data from a large United Kingdom survey. Br J Addict 1989; 84: 541-6.

1.2 Lagro-Janssen T, Liberton IJW. Profielen wan regelmatige gebruikers van benzodiazepinen in een huisartspraktijik. Ned Tijdschr Geneeskd 1993; 137(39): 1969-73

13 Vissers FHA, Knotmerus JA, Vau der Grinten RF Van der Horst FGEM. Langdurig gebruik van slaapen kalmeringsmiddeler in een huisartspraktijk. Huisarts Wet 1993; 36(12): 405-8

14 Van der Waals FW. Sex differences in benzodiazepine use. Dissertatie november 1995 Universiteit van Amsterdam. 15BN 90-9008823-7

15 Comack MA, Sweeney KG, Huges-Jones Foot GA. Evaluation of an easy, cost effective strategy for cutting berzodiazepine use in gentral practice. Br I Gen Pract 1994; 44: 5-8 
hoofdstuk 13

\section{Beschouwing}




\section{Abstract.}

In this chapter the main results of this study are summarized. Some important methodological considerations are discussed. Recommendations for the general practitioner in the care of (potential) benzodiazepine users are made, based on the reproted study and the literature analyses. Finally, suggestions for further research and professional support are put forward. 


\subsection{Inleiding}

Geintrigeerd geraakt door de omvang en 'inhoud" van de baliereceptuur in onze praktijk, zijn we begonnen aan dit wetenschappelijk onderzoek. Balierecepten worden op verzoek van patiënten zónder arts-patiëntcontact verstrekt. Hierbij ligt het accent van de gedeelde verantwoordelijkheid van patiënt en huisarts ten aanzien van indicatie en gebruik bij de patiënt. Als het balierecept voor de patiënt een manier is om het directe arts-patiëntcontact te vermijden en als de huisarts vindt dat er te veel of te snel gevraagd wordt maar het recept toch ondertekent, is daarmee een spanningsveld gecreëerd tussen de patiënt en zijn huisarts.

Het werstrekken van slaap- en kalmeringsmiddelen (met name benzodiazepinen) middels balierecepten roept vragen op omtrent frequentie van voorkomen en bewaking van een verantwoord gebruik. Uit ons onderzoek in vijf huisartspraktijken (hoofdstuk 2) bleken alle huisartsen een vaste groep van langdurig gebruikers te hebben, die hun receptuur voor deze middelen weelal via de balie werstrekt krijgen.

Langdurig gebruik van slaap-en kalmeringsmiddelen is van diverse factoren afhankelijk, zoals het medicament zelf, de indicatiestelling, arts- en praktijkgebonden factoren en patiëntgebonden factoren. Het feit dat de patiënt zelf zijn medicatie 'regelt' zal waarschijnlijk betekenen dat hij zelf de indicatie tot gebruik bepaalt, zeker op langere termijn. Welke factoren in zijn leven hebben hier invloed op?

Een eerste oriëntatie hieromtrent (hoofdstuk 3 ) in de vorm van een pilotstudie in eén huisartspraktijk liet zien dat langdurig gebruikers (gebruik $>1$ jaar) veelal vrouwen waren, dat niet allen eenzelfde patroon van gebruik hadden (sommigen continu, anderen episodisch) en dat er weinig verandering was in het gebruikspatroon na de start van het gebruik, evenmin in de Klachten die reden waren voor het gebruik. Slaapstoornissen bleken het meest woor te komen, terwijl hichamelijke problemen het vaakst genoemd werden als oorzaak van de klachten. De continu gebruikers beoordeelden hun lichamelijke gezondheid als minder gunstig en hadden vaker een depressief reactiepatroon bij het omgaan met problemen.

Uit die literatuurstudie (hoofdstuk 4) kwam naar voren dat inclusiecriteria en onderzochte medicamenten nog al eens verschilden in de bestudeerde onderzoeken. Hiermee rekening houdend vonden we als kenmerken van langdurig gebruikers: vrouwelijk geslacht oudere leeftijd, lage opleiding, het hebben van meerdere gezondheidsproblemen en psychologische problemen. Ook waren de definities van langdurig gebruik lang niet altijd identiek. Enerzijds werd hierbij uitgegaan van de duur van het gebruik, anderzijds werd ook de intensiteit van het gebruik erbij betrokken. Een consistente definiëring van diverse vormen van gebruik van slaapen/of kalmeringsmiddelen is belangrijk in verband met mogelijke verschillen tussen groepen 
onderling als ook voor de vergelijkbaarheid van onderzoeksresultaten.

Uit de pilotstudie bleek ook dat de meerderheid van de gebruikers tevreden was over de werking van het middel en dat ze geen bijwerkingen bemerkten. Het stoppen van de medicatie werd door ruim de helft van de gebruikers een probleem genoemd, met name de continu gebruiker bleek dit naar zijn zeggen niet zonder deskundige hulp te kunnen. Voor zover in de literatuur eerstelijns interventiestudies gevonden werden (hoofdstuk 5), bleck het initiatief van de zijde van de huisartsen maar beperkt succes te hebben, waarbij intensieve begeleiding niet veel beter scoorde dan eenmalige voorlichting, zoals het sturen van een informatieve brief over nadelen van gebruik en veraintwoord gebruik.

Op basis van de pilot- en literatuurstudie lijkt het voorkómen dat iemand langdurig gebruiker wordt belangrijker dan het langdurig gebruik met interventies proberen te minderen dan wel te stoppen. In dit kader is een profiel van de gebruiker of van gebruikersgroepen belangrijk om risicopatiènten tijdig te kunnen herkennen. Deze overwegingen hebben geleid tot het zoeken naxar een indeling in wormen van gebruik en de daarbij behorende karakteristieken, een indeling die zowel voor de dagelijkse praktijkvoering van de huisarts als ook voor onderzoek van belang kon zijn.

\subsection{Bevindingen}

Ten aanzien van de duur van gebruik werd bij de opzet van thet onderzoek overwogen dat de overgang tussen kortdurend en langdurig gebruik eerder rond de drie maanden zou liggen dan de in de literatuur veelvuldig gehanteerde tijd wan 6-12 maanden. Deze keuze van 3 maanden blijkt uit de resultaten van dit onderzoek niet slecht gekozen, mogelijk nog te ruim. De bevindingen sluiten het meest aan bij de indeling die door Balter ${ }^{\prime}$ voor het gebruik van kalmeringsmiddelen gevolgd is, namelijk kortdurend (korter dan 1 maand), cen overgangsgroep en de groep langdurig gebruikers (langer dan 1 jaar), waatbij de termijn van 1 jaar voor langdurig gebruik nog te ruim gekozen lijkt. Het gebruik van slaap- en/of kalmeringsmiddelen langer dan 3 maanden is voor de huisarts een tichtpunt wat betreft risico van langdurig gebruik. Dit is te baseren op de gevonden ferquentieverdeling van duur van gebruik enerzijds en anderzijds op het gegeven dat bekend is uit de literatuur dat het fenomeen van gewenning optreedt bij gebruiksduur van enkele weken ${ }^{2,3}$. Ten aanzien van de vorm van gebruik blijkt kortdurend gebruik voomamelijk ến episode te zijn, terwijl langdurig gebruik twee, qua omvang gelijkwaardige, groepen oplevert, namelijk een groep die continu gebruikt em een groep die dit niet doet. Langdurig gebruikers blijken dus niet als een homogene groep beschouwd te mogen 
worden. Bij alle vormen van gebruik kwamen twee maal zo veel vrouwen voor als mannen. Leeftijd vertoont een sterke samenhang met langdurig gebruik, dat wil zeggen: hoe ouder de patiënt, hoe groter de kans op langdurig gebruik. Bij prescriptie van slaap en kalmeringsniddelen zal door de huisarts vooral bij vrouwen op hogere leeftijd rekening gehouden moeten worden met de kans op langdurig-continu gebruik.

De bevindingen van dit onderzoek zijn weer te geven in drie deelgebieden:

I Karakteristieken van gebruikers op basis van een vergelijking onderling. (hoofdstuk 8 en 9)

II Psychosociale en lichamelijke kenmerken van gebruikers op basis van cen vergelijking met niet-gebruikers.

(hoofdstuk 10 en 11)

III Het oordeel van de huisarts omtrent het toekomstig gebruik van langdurig gebruikers. (hoofdstuk 12)

\section{Karakteristieken van gebruikers, vergelijking onderling}

Uitgaande van de indeling in kortdurend, langdurig-episodisch en langdurig-continu gebruik zijn deze groepen met elkaar vergeleken met betrekking tot de volgende aspecten:

a) De prescriptie en de aanleiding daartoe.

Door alle groepen werden benzodiazepinen het meest gebruikt. De huisarts was voor alle gebruikers in het merendeel van de gevallen degene die het eerste recept verstrekte bij de start van het gebruik. Daarmee is hem op dat moment de gelegenheid geboden dit gebruik te bewaken, hetgeen blijkbaar onvoldoende gebeurd is gezien de continuering wan het gebruik. Grotere waakzaamheid door de voorschrijvend huisarts is dus van belang. Bij de continu gebruikers was echter ook de specialist degene die ten opzichte van de andere gebruikersgroepen, vaker het eerste recept voorschreef. Daarme is het risico aanwezig dat de bewakingsfunctie van de huisarts niet goed mogelijk is. Tijdige terugkoppeling naar de huisarts en een grotere terughoudendheid van de zijde van de specialist ten aanzien van de prescriptie van deze middelen is gewensit.

De klachten waaryoor deze middelen gebruikt werden, veelal slaapstoornissen en gevoelens van angst/spanning/nervositas, waren niet onderscheidend voor de verschillende gebruikersgroepen. Ze geven de huisarts dus weinig houvast. In dit kader is her belangrijker na te gaan wat de oorzalak van deze klachten is. Door alle drie de groepen gebruikers werden problemen met hun gezondheid het meest genoemd: bij de kortdurend gebruikers vooral problemen met hert bewegingsapparaat, het maag-darmkanaal en het hart-vaatstelsel; bij de langdurig gebruikers wooral problemen met het bewegingsapparaat, het hart-vaatstelsel. Het adequaat behande- 
len of het bespreekbaar maken van moeilijkheden met de verwerking van deze gezondheidsproblemen kunnen het gebruik van slaap- en/of kalmeringsmiddelen voorkomen. Voor zover psychosociale problemen oorzaak waren bleken het hebben van problemen met kinderen en problemien met huisvesting geassocieerd met langdurig gebruik. De continu gebruikers onderscheidden zich ten opzichte van de episodisch gebruikers tevens door het hebben van problemen met het verlies van een dierbaar persoon. Het zijn voor de huisarts allemaal herkenbare problemen in de dagelijkse praktijk, die veelal moeilijk oplosbaar zijn. Bij de keuze een psychofarmacon voor te schrijwen is het voor de huisarts van belang het juiste psychofarmacon te kiezen (antidepressiva of hypnotica/tranquilliser) en een goede bewaking te realiseren.

b) Invloeden vanuit het dagelijks leven, persoonskenmerken en gezondheid.

De langdurig gebnikers waren vaker alleenstaand, lager opgeleid, waren vaker eenzaam, vertoonden bij moeilijkheden vaker een depressief gedrag, waren minder expressief, waarbij de continu gebruiker minder aktief was in de aanpak van problemen. Risicopatiënten voor langdurig gebruik kan de huisarts dus veelal vinden in de groep ouderen die vaker alleenstaand zijn en/of eenzaam zijn en een matig coping gedrag vertonen. Ondersteuning en, als besloten wordt een slaap- of kalmeringsmiddel voor te schrijven, bewaking van het medicatiegebruik is van belang. Duidelijke afspraken en goede informatie vooraf zijn daarbij van belang ${ }^{4}$. Een hogere leeftijd brengt ook meer gezondheidsprobllemen met zich mee. In de ogen van de langdurig. gebruikers spe]en deze in ieder geval een belangrijke rol, bij de continu gebruikers nog sterker dan bij de episodisch gebruikers. Wat betreft het gebruik alcohol, waren er geen verschillen tussen de diverse groepen, bij de continu gebruikers waren er zelfs meer mensen die géén alcohol gebruikten. Misbruik van alcohol brengt risico's van verslaving aan psychofarmaca met zich mee door het potentiërend effect van alcohol ${ }^{5}$, het omgekeerde blijkbaar niet, hetgeen ook reeds eerder geconstateerd is ${ }^{6,7}$.

c) Satisfactie, verslaving en behoefte/bereidheid te stoppen. Alle gebruikers hadden in het algemeen weinig bijwerkingen van de gebruikte middelen. Daarbij waren de langdurig gebruikers meer tevreden over het effect van het middel dan de kortdurend gebruikers. Beide feiten zullen voor de langdurig gebruiker geen argument zijn te stoppen. De middelen werken immers goed! Desgevraagd voelden ze, met name de contimu gebruikers, zich wel afhankelijker van het middel dan de kortdurend gebruikers. De ontkenning van nadelen van langdurig gebruik enerzijds en de afhankelijkheid anderzijds zorgen voor continuering van het gebruik. Er zal eerst een bewustmakingproces op gang gebracht moeten worden alvorens een gedragsverandering, in deze het stoppen, zal plaatsvinden " Ook scoorden de continu gebruikers hoger op een verslavingsindex, waarbij het 'drug-seeking' gedrag hen onderscheidde van de episodisch gebruikers. Het vragen naar meer en sterkere middelen moet voor de huisarts een signaal zijn dat langdurig gebruik en verslaving dreigt. Het verstrekken van slaap- en kalmeringsnuid- 
delen zónder arts-patiëntcontact zullen veelal in strijd zijn met het eventueel op gang brengen wan een bewustmakingsproces bij de langdurig gebruikers en het herkennen van hun drugseeking gedrag. Baliereceptuur zal in deze achterwege moeten blijven.

Van de episodisch gebruikers dacht het merendeel zelfstandig het gebruik te kunnen stoppen, van de continu gebruikers was dit slechts een klein deel. Bij een eventuele stoppoging werd de meeste hulp verwacht van de huisarts. Kortom: de episodisch gebruiker wil niet stoppen en de continu gebruiker kan niet stoppen. Desgevraagd geeft de huisarts wel aan dat hij het stoppen bij de langdurig gebruikers in de helft van de gevallen in het verleden besproken heeft, hetgeen echter maar een beperkt resultaat heeft gehad. Mogelijk dat zijn acties het bovenvermeldde bewustmakingsproces nog onvoldoende op gang heeft gebracht.

\section{Kenmerken van gebruikers, vergelijking met niet-gebruikers}

De vergelijking van gebruikers met niet-gebruikers zijn in twee groepen kenmerken uitgevoerd: a) Psychosociale kenmerken.

Ten opzichte van niet-gebruikers bleken alle groepen gebruikers, zonder onderscheid, gemiddeld een groter aantal problemen te ervaren in de loop van een jaar, een groter aantal problemen te hebben die niet opgelost konden worden in de onderzoeksperiode, evenals een grotere hulpvraag erbij te hebben. Ook waren in de probleemlijsten van alle groepen gebruikers meer psychische stoornissen vermeld, hetgeen niet gold voor sociale problemen. Blijkbaar hebben we te maken met een groep patiënten die vaker professionele hulp nodig heeft voor de oplossing van hun problemen; mogelijk dat het meer voorkomen van psychische stoornissen bij hen dit ook nodig maakt. De aard van de ervaren en/of onopgeloste problemen en de hulpvraag daarbij, evenals enkele persoonskenmerken, lieten een onderscheid zien tussen de drie groepen gebruikers en de niet-gebruikers: kenmerken van kortdurend gebruikers waren in dit opzicht het ervaren van gezondheidsproblemen, het hulp vragen bij problemen met mensen in de buurt en bij relatieproblemen en het minder tevreden zijn; voor episodisch gebruikers betroffen dit het hulp vragen bij relatieproblemen en/of problemen met eigen gezondheid, als ook het depressief reageren bij problemen "voor continu gebruikers waren dit het hebben van problemen met kinderen en/of het verlies van een dierbaar persoon, het hulpvragen bij problemen met eigen gezondheid en het ervaren van lichamelijk lijden, minder gelukkig zijn en psychisch minder goed functioneren. Alleen bij de continu gebruikers bleek meer koffie en/of alcoholgebruik voor te komem. Dit in tegenstelling tot de bevinding bij de vergelijking tussen gebruikers onderling dat de groep continu gebruikers minder alcohol zouden gebruiken. Nemen we echter de probleemlijsten van het medisch dossier in ogenschouw dan blijkt de huisarts in beide groepen 
langdurig gebruikers alcoholmisbruik vaker geregistreerd te hebben dan bij niet-gebruikers, en wel het meest bij de continu gebruikers.

b) Somatische kenmerken. Ten opzichte van niet-gebruikers werden door alle gebruikersgroepen naast het psychofarmacon gemiddeld ook meer andere medicamenten gebruikt. De probleemlijsten van alle gebruikersgroepen bewatten meer actieve probleemregels. De aand van de in de probleemlijst opgenomen probleemregels bieden de huisarts maar een beperkt aantal lichamelijke kenmerken van gebruikers: alleen voor de episodisch gebruikers werden in hun probleemlijsten meer problemen gevonden op gebied van het maag-darmkanaal en het vrouwelijke genitale stelsel. Kennelijk zijn er geen verschillen tussen gebruikers en niet-gebruikers wat betreft het voorkomen van gezondheidsprobllemen, maar te oordelen naar het algemeen gebruik van medicamenten en de omvang van actieve problemen in hun probleemlijst, wordt er anders mee omgegaan. Ze zullen daarom ook vaker bij de huisarts komen omwille van lichamelijke klachten of dientengevolge psychische stoornissen. Door gebruikers werden immers gezondheidsproblemen het meest genoemd als oorzaak van hun klachten waarvoor de slaap-en kalmeringsmiddelen gebruikt werden. Niet het hebben van meer of andere gezondheidsproblemen, maar hoe ermee omgegaan wordt bepaait de kans op gebruik van deze middelen.

\section{Toekonstig gebruik en het oordeel van de huisarts}

Uit het onderzoek bleek dat als iemand eenmaal een langdurig gebruiker was, de kans klein was dat de huisarts het initiatief zou nemen een mogelijke verandering van dit gebruik bij de patient ter sprake te brengen. Er was een balans tussen de huisarts en zijn langdurig gebruikers. De kans dat de huisarts het initiatief zou nemen om het gebruik ter discussie te stellen werd vooral bepaald door de gebruiksduur (grotere kans als het gebruik korter dan een jaar is) en de sociale status van de gebruiker (grotere kans bij gescheiden personen).

Het laten bestaan van dit langdurig gebruik berustte vooral op indicatiestelling enerzijds en inschatting van haalbaarheid anderzijds. Misschien dat heroverweging van de verouderde indicatie de mening van de huisarts kan veranderen. Ook is het mogelijk dat de inschatting wan haalbaarheid en mislukken wan voorgaande pogingen te maken heeft met onvoldoende bewustwording/-making van het probleem bij de patiënt. Het verstrekken van een informatieve. brief kan dit bewustmakingsproces bevorderen en mogelijk een reductie van het gebruik teweegbrengen ${ }^{9.10}$. 


\subsection{Methodologische kanttekeningen.}

Het hoofdonderzoek naar kenmerken van gebruik(ers) is uitgevoerd met behulp van een steckproef uit 11 praktijken die qua demografische opbouw vergelijkbaar zijn met de nationale bewolking. Rekening houdend met de prevallentie van gebruik van slaap-en kalmeringsmiddelen heeft de voorselectie door apothekers om gebruikers op te sporen enorm veel werk kunnen besparen. Uiteraard wond witgebreid discussie plaats over hoe de privacy van patiènt-gebruikers zoveel mogelijk zou zijn te waarborgen. Gegevens van deze apotheekselectie bleven in de praktijken, werden vertrouwelijk behandeld en waren alléến toegankelijk voor de huisarts en onderzoeker.

De studie betrof een retrospectief enquête-onderzoek onder patiënt-gebruikers en controlepersonen. Daar patiënt-gebruikers bekend waren door de apotheekselectie konden deze benaderd worden met de tweede enquête over het psychofarmacon ook als ze vergeten hadden (recall bias) dit te vermelden in de eerste enquête (35\%). Bij langdurig gebruik is informatie over de beginperiode uiteraard ook onderhevig aan een vorm van recall bias. Daarom is getracht ontbrekende informatie aan te vullen door patiënten telefonisch hieromtrent te benaderen.. Het longitudinaal aspect van langdurig gebruik is zo veel mogelijk onderzocht door over het gebruik en de determinanten ervan vragen te stellen over drie periodes, namelijk de beginperiode, de periode oktober 1992 - oktober 1993 en een periode 3-6 maanden daama. Een aantal meetinstrumenten (eenzalamheid, coping, gezondheidservaring, kwaliteit van leven) geeft echter door een éénmalige meting een momentaan beeld. Het is onduidelijk in hoeverre bij langdurig gebruik in de loop van de tijd (na de start van het gebruik) in de score op deze meetinstrumenten weranderingen opgetreden zijn. De follow-up ná de onderzoeksperiode was kort waardoor de kans op veranderingen klein was en uitspraken hieromtrent van beperkte waarde zijn.

De ICPC is een veel gebruikt classificatiesysteem in de huisartspraktijk, waarmee het mogelijk is de reden van komst, het diagnostisch en interventie-proces, alsook de diagnosen te classificeren. Het sluit daarmee goed aan op het huisartsgeneeskundig denken en handelen. Er wordt wel veelal uitgegeaan wan categorieën van klachten, problemen en diagnosen. In dit opzicht heeft dit systeem het nadeel dat het grofmazig is. Op diagnoseniveau uitspraken doen is daardoor varak niet mogelijk.

Samenhangend met het surveykarakter van het onderzoek betreffen de determinanten van gebruik die in dit onderzoek naar voren kwamen, met name het gebruik op een bepaald moment, namelijk het moment van bevraging. Derhalve is terughoudendheid betracht in het interpreteren van de betekenis van de determinanten voor toekomstig gebruik.

De non-responsgroep teldde meer oudere mensen ( $>70$ jaar). De groep langdurig gebruikers in 
deze leeftijdscategorie zal in werkelijkheid groter zijn dan door ons gevonden. De enquêtering van de hwisartsen met betrekking tot een steekproef uit de non-respondenten en de respondenten leverde weinig verschillen op, zodat de kans op selectie door non-repons niet zo groot zal zijn. Tenslotte is het wat betreft het longitudinaal aspect denkbaar dat er door het in hoofdzaak retrospectieve karakter van de studie sprake is van selectieve uitval vóraf. We hebben echter geen aanleiding te veronderstellen dat dit effect relewant is, omdat onder andere sterfie en vertrek in relatie tot benzodiazepinegebruik niel vaak voorkwam.

Het onderzoek naar het oordeel van de huisarts omtrent het motiveren van langdurig gebruikers van benzodiazepinen dit gebruik te stoppen, is uitgevoerd in een beperkt aantal academische praktijken. De bevindingen dienen daarom met enige omzichtigheid geïnterpreteerd te worden.

\subsection{Aanbevelingen}

\section{Preventie wan langdurig gebruik}

Langdurig gebrukers oordelen positief over het nut van slaap-en/of kalmeringsmiddelen, zijn tevreden over de werking van het middel en ervaren weinig nadelige effecten van het gebruik. De episodisch gebruiker wil niet stoppen en de continu gebruiker kan het niet. Preventie van langdurig gebruik lijkt dus minstens zo belangrijk als achteraf de langdurig gebruiker te adviseren het gebruik te verminderen of te stoppen. In het kader van preventie van langdurig gebruik van slaap- of kalmeringsmiddelen ziju een aantal uitgangspunten van belang:

- De huisarts speelt bij de start van het gebruik van slaap- of kalmeringsmiddelen een belangrijke rol en is als zodanig degene die een verantwoord gebruik van deze middelen dient te bevorderen. Ook het aandeel van de specialist in het voorschrijven is, vooral bij de continu gebruikers, niet onaanzienlijk gebleken. Specialisten dienen een zo groot mogelijke terughoudendheid te betrachten ten aanzien van het voorschrijven van deze middelen. Dit geldt ook tijdens opname van de patiènt in het ziekenhuis ${ }^{11,12}$. Indien tot prescriptie besloten wordt is aen snelle rapportage van de specialist gewenst; bij vragen om herharalrecepten is verwijzing naar de huisarts op zijn plaats.

- Huisartsen onderling dienen binnen de huisartsengroep goede afspraken te maken omtrent receptaanvragen voor deze middelen tijdens waarneming om "shoppen" te voorkomen.

- Het verstrekken van recepten voor deze psychofarmaca aan "starters" dient vergezeld te gaan van informatie over voor- en nadelen van deze middelen, met name lange-termijneffecten $^{13}$. Naast mondelinge informatie kan meegeven van een folder daarbij mogelijk ondersteunend werken ${ }^{14,15}$. Hier ligt een taak voor huisarts en/of apotheker. Een goede 
afstemming is hier op zijn plaats. Het voorschrijven van kleine hoeveelheden op het recept voor een korte periode en het advies om terug te komen als de patient het gebruik wil contimueren zal het risico van inadequaat gebruik verkleinen. In dit kader dient verlenging van het recept voor deze medicatie niet via de balle te geschieden.

- Bij het voorschrijven van slaapmiddelen dient de keuze voor non-benzodiazepinen owerwogen te worden. Vergelijkend onderzoek suggereert dat ze ten opzichte van de benzodiazepinen bij chronische insomnia een even goede werking hebben met minder nadelige effecten ${ }^{16}$; bevestiging hiervan in prospectief eerstelijns onderzoek is wenselijk.

- Potentiële gebruikers presenteren zich vaak bij huisarts of specialist mogelijk met gezondheidsproblemen. Omdat gebleken is dat met name problemen met het bewegingsapparaat of het hart-vaatstelsel en de verwerking hiervan een opstap zijn naar gebruik van slaap- en/of kalmeringsmiddelen, is bijzondere ondersteuning van de patiênt in deze gewenst ter voorkoming van het inadequaat (gaan) gebruiken van slaap- en/of kalmeringsmiddelen.

- De huisarts dient zich ervan bewust te zijn dat een aantal factoren op langdurig gebruik kumnen duiden: het vrouwelijk geslacht, een hogere leeftijd., grote tevredenheid over de werking van het middel, een depressief reactiepatroon bij moeilijkheden en het hebben van problemen met kinderen of huisvesting. Verslavingsgedrag, het verlies van een dierbaar persoon (rouwproces) en het ervaren van een slechte gezondheid zijn woor continu gebruik risicofactoren gebleken. Als besloten is om deze middelen te laten gebruiken dient de huisarts bij aanwezigheid van een of meerdere van deze risicofactoren het gebruik strikt te monitoren, zich niet al te snel mee te laten slepen bij wragen naar meer pillen, of andere sterkere middelen. Bij het voorschrijwen van psychofarmaca dient tevens afgewogen te worden of een antidepressivum niet beter op zijn plaats is.

- Voor langdurig gebruikers is naast het ervaren van problemen, zoals problemen met kinderen en het verlies wan een dierbaar persoon, ook het hulpvragen ervoor kenmerkend: dit gelldt met name voor het hulpvragen bij gezondheidsproblemen en relatieproblemen. Hier is voor de huisarts een belangrijke ondersteunende functie weggelegd, om te voorkomen dat de patiënt zijn toevlucht neemt tot slaap-en/of kalmeringsmiddelen.

- Een ouder persoon heeft meer kans op somatisch lijden. Niet zozeer de aard maar het hulp vragen bij lichamelijk lijden blijkt voor langdurig gebruikers kenmerkend te zijn. Somatisch lijden kan oorzaak zijn van psychische stoornissen (slaapproblemen, angst, spanning). Het is voor de huisarts een belangrijke afweging deze stoornissen te behandelen of zijn aandacht meer te richten op de somatische stoomis, die eraan ten grondslag ligt.

- De probleemlijst is niet alleen een historisch overzicht wan bellangrijke gebeurtenissen op het gebied van gezondheid, het is ook een instrument. Voor het inschatten van het risico 
voor langdurig gebruik bleek het wórorkomen van psychische stoornissen in deze lijst een voorspellend kenmerk van langdurig gebruikers te zijn. De huisarts moet dit instrument gebruiken ter preventic van langdurig gebruik, namelijk als hij bij het inzien van deze lijst psychische stoormissen tegenkomt kan dit een contra-indicatie voor prescriptie van slaapen/of kalmeringsmiddelen betekenen. Ook inzake de keuze van woor te schrijven medicamenten, dat wil zeggen de afweging benzodiazepinen of antidepressiva, kan deze lijst dan richtinggevend zijn.

\section{Begeleiding wan de bestaande groep langdurig gebruikers}

Wanneer preventie van langdurig gebruik mislukt is, dan is het zaak de gebruikers goede begeleiding te bieden. Ook al geeft de gebruiker aan dat er geen bijwerkingen zijn, toch heeft het langdurig gebruik van slaap- en kalmeringsmiddelen zijn nadelen. Dat zijn onder andere beïnvloeding van cognitief functioneren, sedatie, affectieve vervlakking, een hoger valrisico door spierzwakte en verminderde reactiesnelheid. Het lijkt dus zinvol bij de begeleiding van langdurig gebruikers te proberen dit gebruik zo goed mogelijk te monitoren:

- Allereerst dient een bewustmakingsproces in gang gezet te worden bij de patiënt-gebruiker. In dit kader wall te denken aan een informatiefolder of brief ower de neveneffecten van langdurig gebruik, waarvan gebleken is dat deze actie een reducerend effect heeft op het gebruik $^{9}$.

- Een kritische blik van de huisarts omtrent het (langdurig) gebruik lijkt ook zinvol. Welke indicatie is er nú voor het gebruik van het slaap-en/of kalmeringsmiddel; is gekoppeld aan deze diagnosestelling een ander geneesmiddel niet beter?

- Het bewaken van het langdurig gebruik is minstens even belangrijk. Enkele regeis dewarvoor zijin:

*het ruiteren van de Jangdurig gebruikers, hetgeen zinvol is om in de bulk van balierecepten deze groep snel te kunnen herkennen.

* het instrueren wan de doktersassistente om bij de vraag om een balierecept een verandering in het gebruikspatroon van de langdurig gebruiker te signaleren teneinde het drug-seeking gedrag tijdig te kunnen herkennen en de gebruiker hierop te kunnen attenderen. De computer is in dezen een zeer nuttig instrument.

*het circuit van het voorschrijven en verstrekken van slaap-en kalmeringsmiddelen moet sluitend zijn. Dat de gebruiker gaat 'shoppen' en op diverse plaatsen zijn middelen vraagt moet zo veel mogelijk voorkomen worden. Met collega huisartsen, specialisten en apotheken dienen afspraken gemaakt te worden over het voorschrijven en bewaken. De meest ideale oplossing zou een centrale en privacy-veilige database zijn waar voorschrijvend arts en apotheker informatie vragen en gegevens opslaan. 
- Als de patiënt-gebruiker aangeeft te willen stoppen en daarbij hulp vraagt, of als er dringende redenen zijn de gebruiker te adviseren te stoppen, dan is het belangrijk hem/haar te begeleiden met duidelijke afspraken over een te volgen afbouwplan ${ }^{17}$, waarin ook frequente spreekuurcontacten aangeboden moeten worden. Duidelijke afspraken over receptverstrekking zijn een onderdeel van dit plan; het informeren van apotheker, collega huisartsen en eventueel behandelende specialisten is daarbij aan te bevelen. Verwijzing naar instellingen als verslavingszorginstanties, RIAGG's, zelfhulpgroepen, vrouwenhulpverleningsinstanties, maatschappelijk werkinstanties en psychiatrische instellingen, die bij het terugdringen van medicijnverslaving behulpzaam kunnen zijn, is het overwegen waard. ${ }^{18}$

\section{Verder onderzoek}

Het gebruik van slaap- en kalmeringsmiddelen is door dit onderzoek op een aantal punten verduidelijkt. Uit de literatuur reeds bekende gegevens zijn bevestigd en aangevuld. Er zijn echter nog onbeantwoorde vragen, waarvoor verder onderzoek nodig is:

- Heeft episodisch gebruik dezelfde nadelige effecten op de gebruiker als continu gebruik? Zijn ontwenningsreacties soms de oorzaak van continuering van episodisch gebruik? Het feit dat een grote groep episodisch gebruikers gevonden is, maakt het de moeite waard ten aanzien van deze aspecten nader onderzoek te doen

- Om langdurig gebruik van slaap- en kalmeringsmiddelen kritisch te kunnen beschouwen is het noodzakelijk dat gedetailleerde informatie beschilkbaar is over de indicatie. Hierbij is een diagnosestelling noodzakelijk en dient de huisarts te bezien of hij verder kan gaan dan een klacht/diagnose. Onderzoek naar het vóótkomen van psychische stoornissen bij langdurig gebruikers in de eerstelijn is gewenst, waarbij het gebruik van een fijnmaziger classificatiesysteem gewenst is. Hierbij is samenwerking met psychiaters die enige bekendheid hebben met de eerstelijn aanbevelenswaardig.

- Het omgaan met psychosociale problemen en verslechtering van de gezondheid wordt door een deel van de patienten als problematisch ervaren, waardoor er psychische klachten ontstaan. Onderzoek naar een mogelijk genetische alanleg voor deze beperkingen in copinggedrag kan mogelijk leiden tot een meer causale therapie.

- Eerstelijns interventie-onderzoek met farmacologische en psychische ondersteuning van de langdurig gebruiker die wil gaan stoppen, kan gegevens opleveren die de huisarts behulpzaam zijn bij het begeleiden van stoppogingen.

- De huisarts zou bij behandeling van psychische klachten moeten kunnen beschikken over alternatieven voor slaap- en kalmeringsmiddelen. Onderzoek naar nieuwe mogelijkheden en de effecten ervan zou het gevoel van machteloosheid bij de huisarts kunnen beperken. 


\section{Literaturur}

Balter MB, Manheinier DI, Mellinger GD, Uhlenhuth EH. A cross-national comparison of anti-anzide ty/sedalive drugs use. Curr Med Res Opir 1984; 8(suppl 4): 5-20

2. Laan var der $J W$. Afhankelikheid van benzodiaxepinen: omwang, risilco's en ewentuele verschillen tusen de middelen onderling. Ned Tijdschr Geneeskd 1984; 128:817-9

3 Steerikiste van M. Roeck de J. Afhankelijkheid en abstinentieverschijnselen bij gebruik wan benzodiazepinem. Ned Tujdschr Geneeskd 1986; $130(27): 1224$-7

Haafkens J. Rituals of silence. Long-term tranguilliser use by women in the Netherlands. A social base study. Dissertatie 1997 Amsterdam. ISBN 90-5589-062.6. Pepplinkhuizen $\mathbb{L}$, Verhoeven WMA, Does van der E, Sitsen JMA. Het Psychatrisch Fommularium, eath prabitische leidradad. Rotterdan 1997. Erasmus Publishing. ISBN 90-5235-093-0

Mellinger $\mathrm{GD}$, Balter $\mathrm{MB}$, Mannheiner $\mathrm{DI}$, Cisin $\mathrm{IH}_{\mathrm{n}}$ Parry HJ. Psychic distress, life crisis and use of psychotherapeutic medications. Anelh Gen Psychiatry 1978; 35: 1045-52.

Dunbar GC, Morgan DD, Perera KMH. The concurnent use of alcohol, cigarettes and caffeine in britith benzodiazepine users as measured by a generall population survey. Br I Addiction 1988; 83:689-94.

8 Miller WR . Rollnick S. Motivational inverviewing; preparing people to change addictive behaviour. The Guildford press, New York/London 1991

9 Cormack. MA, Sweeney $\mathrm{KG}$, Huges-Jones Foot GA. Evaluation of an easy, cost effective strategy for cutting benzodiazepime use in general practice. Br I Gen Pract 1994; 44:5-8

10 Verberk H. Benzodimzepinen; (voor wie) zijn ze een probleem? Patient Care 1993; 20 (2): 34-46:

11 Hallens RJG, Lendfers ML, Cox K. Sleep medication in Dutch hospitals. J Adw Nurs 1991; 16: 1422.7

12 Halfens $\mathbb{R}$, Cox K, Kuppen-Van Merwijk A. Effect of the use of sleepmedicalion in Dutch hospitals on the use of sleepmedication at home. J Adv Nurs 1994; 19(1):55-70

13 Haafkens $J$. Rituals of silence. Long-term tranquilliser use by women in the Netherlands. A social case study. Dissertatie 1997 Ansterdam. ISBN 90-5589-062-6.

14 Parinello K. Patients' evaluation of a teaching booklet for arterial bypass surgery. Patient Education and Counseling $1984 ; 5(4): 183-8$

15 Sherr $\mathrm{L}$, Hedge $\mathbb{B}$. The impact and use of written leaflets as a counseling alternative in mass antenatal HIV screening. Aids Care $1990 ; 2$ (3): 235-45

16 Nowell PD, Mazundar S, Buysse DJ, Dew MA, Reynolds CF, Kupfer DJ. Benziodiazepines and Zollpidem for chronic insomuia.. A meta-analysis of treatment efficacy. JAMA 1997; 278(24):2170-7 Anonymus. Stoppen met benzodiazepinen. Geneesmiddelen bulletin 1994; 28; nr 12:98-101. De Gijsel S. Benzodiazepinen in de huisartsempralktijk. Achtergronden, handwatten en verwijzingen voor huisartsen om wrow wen met een langdurig benzodiazepinegebrük te motiveren tot afbouwen. Vrouwengezondheidscentrum HARA. Leiden 1995. 
hoofdstuk 14

\section{Samenvatting}



Dit proefschrift beschrijft de resultaten van een onderzoek in een aantal huisartspraktijken naar het gebruik van slaap- en kalmeringsmiddelen. Een indeling in onderscheidende groepen gebruikers wordt beschreven.

\section{hoofdstuk 1}

In hoofdstuk 1 wordt de aanleiding tot dit onderzoek beschreven. Verder wordt het onderwerp van dit proefschrift ingeleid. Historie, farmacologische eigenschappen, indicaties, voor-en nadelen van slaap- en kalmeringsmiddelen worden beschreven. Uit praktijkervaring blijkt dat deze middelen, veelal benzodiazepinen, door een vaste groep patiënten langdurig gebruikt worden. Verandert dit gebruik in de loop van de tijd? Is dit langdurig gebruik afhankelijk van de te verwerken problematiek? Is er sprake van een kwetsbare patiënt? Gedoogt de huisarts dit gebruik, wetende dat deze middelen op den duur qua effectiviteit veranderen en verslawingsaspecten op de voorgrond kunnen treden?

\section{hoofdstuk 2}

Dit hoofdstuk is een beschrijving van een oriënterend onderzoek in een vijftal huisartspraktijken naar het voorkomen van baliereceptuur. De baliereceptuur vormde toen $30 \%$ van de totale receptuur. Drie kwart ervan was herhaalreceptuur, die in het merendeel van de gevallen door de huisarts in het verleden voor de eerste keer was voorgeschreven. De belangrijkste via de balie woorgeschreven groepen medicamenten waren achtereenvolgens: medicamenten voor de luchtwegen, psycholeptica, medicamenten voor het hart-vaatstelsel en voor de huid. De psycholeptica bleken voornamelijk benzodiazepinen te zijn. Deze bevinding was reden om nader onderzoek te doen naar het gebruik van slaap- en kalmeringsmiddelen.

\section{hoofdstuk 3}

In hoofdstuk 3 is het onderzoek beschreven naar het langdurig gebruilk van slaap- en kalmeringsmiddelen in eigen praktijk. Alle patiènten die een herhaalrecept vroegen, werden ingesiloten in het onderzoek, verdeeld in kortdurend gebruik ( $\leq 1$ jaar) en langdurig gebruik ( $>1$ jaar); dit latste werd nog opgesplitst in episodisch en continu gebruik. Van deze herhaalrecepten werd $80 \%$ afgegeven via de balie. Problemen met eigen gezondheid al dan niet in combinatie met psychosociale problemen waren reden voor gebruik. Door $84 \%$ van de onderzochte patienten werd het middel langer dan 1 jaar gebruikt. Bij deze langdurig gebruikers werd weinig verandering geconstateerd in de klacht waarvoor men het middel gebruikte en de gepercipieerde oorzaak ervan. Dit zelfde gold ook voor het gebruikspatroon. De continu gebruikers hadden een slechtere beleving van eigen somatische gezondheid dan de episodisch gebruikers. Ze gaven ook vaker aan het gebruik niet zonder deskundige hulp te kunnen stoppen. 


\section{hoofdstukken 4 en 5}

De literatuurstudie is in twee hoofdstukken beschreven. In Medhine werden publicaties geselecteerd vanaf 1962 tot en met 1995, verder werden ook referentielijsten van artikelen gebruikt om relevante publicaties op te sporen. De voorkeur ging uit naar eerstelijns onderzoek met controlegroep. In hoofdstuk 4 wordt de literatuur beschrewen omtrent gebruikspatronen, indicaties en karakteristieken van gebruikers. Het vergelijken van diverse studies werd bemoeilijkt door verschillen in type onderzoek, onderzochte geneesmiddelen en inclusies. Er zijn in de literatur meerdere begrippen verschillend gedefinieerd en gehanteerd voor diverse vormen van gebruik. Voor zover onderzocht bleek de indicatiestelling bij vrow wen vaker zonder relevante symptomen of diagnosen te zijn. Kenmerken van langdurig gebruikers waren het vrouwelijk geslacht, oudere leeftijd, het helbben van meerdere gezondheidsproblemen, psychische problew men en lage opleiding.

Hoofdstuk 5 beschrijft interventiestudies van langdurig gebruik enerzijds gericht op de patièntgebruiker, anderzijds gericht op verandering van prescriptiegedrag van de huisarts. Ex werden tien typen patientgerichte interventies gevonden. In de helft van de gevallen ging het om een vorm van bewustmaking van de patiënt-gebruiker door middel van een brief, een informatiefolder of een gesprek. In de vier gecontroleerde onderzoeken varieerde het percentage stoppers van 1.8-50 procent en het percentage dat het gebruik verminderd had van 8-43 procent. In twee van de vier onderzoeken werd een positief verband gevonden tussen een lage gebruiksdosis en het succes van de interventie. Er waren geen statistisch significante verschillen in resultaat wat betreft geslacht, duur van gebruik, methode van afbouw en type praktijk. Significante verschillen tussen de onderzochte interventievormen werden niet gevonden. Het sturen van een brief of een informatief gesprek had ook een significante reductie van langdurig gebruik tot gevolg. Van de drie onderzoeken naar artsgerichte interventies was er éen studie waarin een significant verschil werd gevonden tussen de interventie (persoonlijke informatie en intensieve feed back) en de controlegroep.

\section{hoofdstukken 6 en 7}

De probleemstelling en daaruit voortvloeiende vraagstelling voor het onderzoek worden in hoofdstuk 6 beschreven. De volgende vraagstellingen werden geformuleerd:

-In welke mate hangen aspecten van het dagelijkse leven (zoals consumptie van genotmiddelen, levensgebeurtenissen, stress en omgaan met stress/coping) en van gezondheid samen met incidenteel, episodisch, respectievelijk continu gebruik van slaap- en kalmeringsmiddelen?

-In welke mate is er een samenhang tussen de aanleiding tot het voorschrijven en de kenmerken hiervan enerzijds en het incidenteel, episodisch of continu (gaan) gebruiken 
van slaap-en kalmeringsmiddelen anderzijds?

-In hoeverre wordt het langdurig gebruik van slaap- en kalmeringsmiddelen als een probleem ervaren en in hoeverre is er behoefte/bereidheid om te stoppen?

-In welke mate zijn er verschillen tussen gebruikers van slaap-en kalmeringsmiddelen en niet-gebruikers wat betreft het ervaren wan gebeurtenissen in het dagelijks leven en/of gezondheid?

In hoofdstuk 7 komen de opzet van het hoofdonderzoek (enquête-onderzoek) en gebruikte meetinstrumenten in de drie enquêtes aan de orde. De opbouw van de onderzoekspopulatie wordt beschreven, de gevolgde procedure en de data-analyse. Uiteindelijk resteerde voor het onderzoek een gebruikersgroep van 705 personen en een controlegroep van 883 personen. De gebruikers werden ingedeeld in kortdurend gebruikers $(\leq 3$ maanden en onderverdeeld in éénmalig en episodisch) en langdurig gebruikers ( $>3$ maanden en onderverdeeld in episodisch en continu). Tot slot is nog de opzet van een onderzoek beschreven naar de actiebereidheid van huisartsen ten aanzien van interventie bij langdurig gebruik van benzodiazepinen.

\section{hoofidstuk 8}

Dit hoofdstuk presenteert een vergelijking tussen de diverse groepen gebruikers van slaap-en kalmeringsmiddelen beschreven ten aanzien van gebruikswijze, redenen voor gebruik en karakteristieken van gebruikers. Van negen huisartspraktijken werd een steekproef van 506 gebruikers verdeeld in vier categorieën gebruikers: kortdurend (eenmalig of episodisch) gebruikers en langdurig (episodisch of continu) gebruikers. Kortdurend gebruik werd daarbij als volgt gedefinieerd: gebruik maximaal 3 maanden. Het gebruik van slaap- en kalmeringsmiddelen betrof meestal benzodiazepinen (95\%). Van de kortdurend gebruikers gebruikte $92 \%$ het middel maximaal 2 maanden. Langdurig gebruikers namen hun middel in $42 \%$ van de gevallen dagelijks. De huisarts of diens collega was meestal degene die het eerste recept verstrekte voor deze middelen. In de onderzochte groepen gebruikers kwamen meer vrouwen voor dar mannen. Ten opzichte van kortdurend gebruikers hadden de langdurig gebruikers andere sociale kemmerken (een hogere leeftijd, vaker alleenstaand, minder vaak in het arbeidsproces betrokken, vaker ziekenfondsverzekerd) en andere persoonskenmerken (vaker eenzaam, andere coping-stijlen). De ervaring van hun geestelijke en lichamelijke gezondheid was wan lagere kwaliteit en analoog daaraan bevatte hun probleemlijst in het elektronisch medisch dossier meer problemen. Alle gebruikers noemden gezondheidsproblemen (vooral problemen met bewegingsapparaat en hart-vaatstelsel) vaker dan psychosociale problemen als oorzaak van de klachten waarvoor het middel gebruikt werd. Er was bij langdurig gebruik weinig verandering te zien in de loop van de tijd wat betreft het gebruikspatroon en de klacht(en).

Vergeleken met kortdurend gebruik was langdurig gebruik geassocieerd met oudere leeftijd, 
eerder depressief reageren bij problemen, een hogere score op een medicijnverslavingsindex, vaker problemen hebben met kinderen of huisvesting, meer tevreden zijn over het effect van het middel. Ten opzichte van langdurig-episodisch gebruik was continu gebruik geassocieerd met een hogere score op de medicijnverslavingsindex, oudere leeftijd, lager opleidingsniveau, verlies van een dierbaar persoon en slechtere kwalificatie van (somatische) gezondheidservaring.

\section{Hoofdstuk 9}

Hoofdstuk 9 beschrijft een onderzoelk naar bijwerkingen, satisfactie, afhankelijkheid en stoppen van het gebruik van het slaap-en/of kalmeringsmiddel. De meningen van de gebruikers en hun huisarts zijn hieromtrent gepeild. De gebruikers bleken in het algemeen weinig bijwerkingen aan te geven, de huisartsen noemden vooral afhankelijkheid als nadelig effect. Tevredenheid over de werking van het middlel lag bij de langdurig gebruikers hoger dan bij kortdurend gebruikers. Ten opzichte van de kortdurend gebruikers scoorden alleen de langdurig-continu gebruikers significant hoger op een medicijnverslavingsindex, waarbij het verschil ten opzichte van de langdurig-episodisch gebrukkers in deze score werd bepaald door een sterker 'drugseeking' gedrag. Aan dit 'drug-seeking" gedrag werd door de huisartsen vaak toegegeven: in slechts $17 \%$ wan de gevallen werd gerapporteerd het voorschrift nooit te veranderen bij de vraag van de langdurig gebruikers naar meer of sterkere middelen. De huisartsen rapporteerden bijna de helft van de langdurig gebruikers ooit gernotiveerd te hebben tot stoppen, waarbij het in een kwart van de gevallen ook tot stoppoging kwam. Alleen de continu gebruikers gaven in het merendeel van de gevallen aan dat ze zónder hulp hun gebruik níet zouden kunnen staken.

\section{hoofdstuk 10}

Verschillen in psychosociale kenmerken van gebruikers van slaap- of kalmeringsmiddelen en niet-gebruikers worden gerapporteerd in hoofdstuk 10. Van 11 praktijken wordt een steekproef van gebruikers ( $n=705$ ) geënquêteerd en vergeleken met controlepersonen, gematcht op praktijk, geslacht en leeftijd. De gebruikers zijn ingedeeld in kortdurend gebruikers ( $\leq 3$ matad), (langdurig-)episodisch gebruikers en (langdurig-)continu gebruikers (langdurig gebruik is gedefinieerd als $>3$ maanden). Ten opzichte van de controlegroep hadden alle gebruikers meer langdurige moeilijkheden ervaren in de loop van ến jaar. Ze vroegen vaker hulp bij het oplossen van deze problemen. Bij alle onderzochte personen bleek ongeveer $75 \%$ van alle problemen alan het eind van het onderzoeksjaar niet opgelost te zijn.

De kortdurend gebruikers bleken in de volgende psychosociale kenmerken te verschillen van de niet-gebruikers: ze waren minder tevreden, hadden meer gezondheidsproblemen, vroegen vaker hulp bij problemen met mensen in de buurt en/of relatieproblemen en hadden meer psychische 
stoormissen (vooral surmenage) in hun probleemlijst. De episodisch gebruikers hadden vaker een depressieve reactie bij het verwerken van problemen, zij vroegen vaker hulp bij relatieproblemen en/of gezondheidsproblemen en hun probleemlijst had meer (diverse) psychische stoomissen. De continu gebruikers ervoeren meer somatisch en psychisch lijden, waren minder gelukkig, ze hadden vaker problemen met kinderen en/of het verlies van een dierbaar persoon, zij vroegen vaker hulp voor eigen gezondheidsproblemen en hun probleemlijst bevatte meer (diverse) psychische stoornissen. Allen bij continu gebruikers kwam meer alcoholgebruik woor.

\section{hoofdstuk II}

In hoofdstuk 11 worden verschillen in somatische kenmerken tussen gebruikers van slaap- of kalmeringsmiddelen en niet-gebruikers geanalyseerd. De onderzoekspopulatie is dezelfde als die uit hoofdstuk 10. Van alle gebruikers stelde ongeveer de helft dat gezondheidsproblemen oorzaak van de klacht waren waarwoor het slaap- en/of het kalmeringsmiddel gebruikt werd. Kortdurend gebruikers noemden vooral problemen op gebied van het bewegingsapparaat en het maag-darmkanaal. De langdurig gebruikers (episodisch en continu) vooral op gebied van het bewegingsapparaat en het hart-vaatstelsel. De klachten die ze hadden waren vooral slaapproblemen en gevoelens van angst, spanning of nervositeit. Alle gebruikers namen gemiddeld meer andere medicamenten. De probleemlijsten van alle gebruikers bevatten ten opzichte van die wan de niet-gebruikers gemiddeld meer aktieve probleemregels. Bij vergelijking van de ICPC hoofdstukken waarin de probleemregels gecodeerd zijn in de probleemlijsten was geen verschil te zien tussen kortdurend gebruikers en niet-gebruikers. De langdurig gebruikers werschilden wel: de episodisch gebruikers hadden meer problemen die betrekking hadden op het maag-darmkanaal, het vrouwelijk genitaal stelsel en psychische stoomissen, de continu gebruikers meer problemen met betrekking tot psychische stoornissen.

\section{hoofdstuk 12}

Hoofdstuk 12 presenteert een studie in vier praktijken, waarvan de huisartsen zijn geẻnquêteerd over een steekproef van 295 langdurig (>3 maanden) gebruikers van slaap-en/of kalmeringsmiddelen. Gevraagd is naar hun mening over het wel of niet continueren van thet gebruik van het middel. De steekproef bevatte ten opzichte van de praktijkpopulaties meer vrouwen, ouderen en laag opgeleiden, hetgeen kenmerken zijn van langdurig gebruikers. Ook waren in de steekproef meer ziekenfondsverzekerden, weduwen/weduwnaren, alleenstaanden en mensen die in een bejaardenhuis woonden. Volgens de participerende huisartsen was het stoppen van het benzodiazepine-gebruik in $43 \%$ van de gevallen geindiceerd, echter bij $70 \%$ van deze groep achtten zij dit niet haalbaar. Door de huisartsen werd slechts $11 \%$ wan de personen uit de steekproef alls potentiële stoppers gezien. Voorspellend ten aanzien van deze 
selectie door de huisartsen waren de gebruiksduur (korter dan 1 jaar) en de sociale status (grescheiden).

\section{hoofdstuk 13}

De resultaten van beschreven onderzoeken worden in hoofdstuk 13 bediscussieerd in relatie tot de volgende drie onderwerpen:

-karakteristieken van gebruikers op basis van een vergelijking onderling

-psychosociale en somatische kenmerken van gebruikers op basis van vergelijking

met niet-gebruikers

-de langdurig gebruikers en hun toekomstig gebruik, naar het oordeel van de huisarts.

Vervolgens word een aantal aanbevelingen gedaan voor de dagelijkse praktijk gericht op preventie van langdurig gebruik en op bewaking wan de groep langdurig gebruikers. Tot slot worden voorstellen gedaan voor verder onderzoek. 
chapter 14

Summary 

This thesis contains the results of a study in several general practices concerning the use of hypnotics and tranquillizers. A classification of several groups of users is given.

\section{chapter I}

In chapter 1 the subject of the thesis is introduced and the motivation for the choice of the topic is presented. History, pharmacological characteristics, indications, advantages and disadvantages of hypnotics and tranquillizers are described. From experience in general practice we learn that a fixed group of patients takes these agents, mostly benzodiazepines, for all long time. Does the use change in the course of time? Does the long-term use depend on problems that the patient has to cope with? Is the user a vulnerable patient? Does the general practitioner facilitate this long-term use, despite the fact that the activity of these drugs will change in time and addiction can ensue?

\section{chapter 2}

This chapter describes an explorative study in five general practices, concerning drug-prescriptions without a doctor-patient encounter. In about 30 percent of all prescriptions were asked at the reception desk (1987). Nearly 75 percent of those were repeat prescriptions, prescriptions that had mostly been initiated by the general practitioner. The prescriptions usually asked at the desk were psycholeptics, drugs for the respiratory or circulatory tract, for the skin and analgesics. Most psycholeptics proved to be benzodiazepines. The latter finding was the reason to do further research on the use of hypnotics and tranquillizers in our own practice.

\section{chapter 3}

In this chapter the study of the long-term use of hypnotics and tranquillizers in our own practice is described. All patients who asked a repeat prescription were included and divided in short-term ( $\leq 1$ year) and long-term ( $>1$ year) use. The latter were subdivided in episodic and continuous use. 118 patients who asked a repeat prescription for hypnotic or tranquillizing drugs participated. Eighty percent of those 'repeats' were provided without a doctor-patient encounter. Health problems, with or without psychological problems, were the complaints for which the psychofarmacon was used. Fourty eight percent of the users, used the drug for more than one year. This group of long-term users showed almost no change in their complaints or in the problems causing these complaints. The pattern of use changes only slightly in the group of long-term users. The patients who were using the drag continuously (daily) experienced their health to be less satisfactory than those used the drug episodically. They also talked more often with their general parctitioner about reducing or stopping the drugs and often had a feeling that they could not stop without the help of an expert. 


\section{chapters 4 and 5}

The literature is presented in two chapters. Publications were selected from Medline (19621995). Moreover lists of references out of articles were used to find other relevant studies. We preferred primary care research with controls.

In chapter 4 we present datat from the literature conceming patterns of use, indications and characteristics of users. Comparing studies was difficult because of differences in type of research, inclusion criteria and types of studied drugs. A variety of patterns of tranquillizer use were found. Compared with men, women more often approved to take these drugs without relevant complaints or diagnoses. Being a woman and having a high age was associated with long-term use. Long-term users had more health and psychological problems, and used more concomittant drugs. There was no relation between the use of hypnotics or tranquillizers and the use of alcohol, coffee or tobacco. Chapter 5 describes several studies concerning interventions of long-term use that were aimed at the patient-user on one hand and on the other hand at changing the prescribing behaviour of the general practitioner. Ten studies were found with several types of interventions for users; half of these trials used a letter, information sheet or consultation to make the users aware of the problem of long-term use. In four controlled trials 18 to 50 procent of patients stopped and 8 to 43 procent reduced their consumption of benzodiazepines. Two investigations found a relation between reduction and low baseline consumption. There were no differences between patients who were succesful or unsuccesful in reducing the medication in terms of sex, duration of use, strategy of reduction or type of practice; also there were no differences between the various types of intervention. Even a single letter or informative encounter resulted in a significant reduction of long-term use.

Three trials concerned the prescription behaviour of the general practitioner. A difference between interventiongroup (personal information and intensive feedback) and the controlgroup was found in only one study.

\section{chapters 6 and 7}

In chapter 6 the reader will find the research questions:

what is the influence of daily life (habits, life events, coping with these events, stress) and of health on several types of using hypnotics or tranquillizers (occasional, episodic or continuous)?

-to what degree is there a connection between the indication or characteristics of prescribing and the use (occasional, episodic or continuous) of hypnotics or tranquillizers?

-is long-term use of hypnotics or tranquillizers experienced as a problem, and to what degree do patients feel a need or willingness to stop using these drugs?

ware there differences between users of hypnotics or tranquillizers and non-users concer- 
ning experience of and coping with life events and/or health problems?

Chapter 7 presents the design of the main study and the instruments used in the three questionnaires. Research population, procedure and data analysis are described. The group investigated consists of 705 users and 883 controls. The users were divided in short-term users ( $\leq 3$ months and subdivided in occasional and episodic users) and long-term users ( $>3$ months and subdivided in episodic and continuous users). In the end the design is described of a study concerning willingness of general practitioners to intervene in long-term use of benzodiazepines.

\section{chapter 8}

In this chapter we compared several groups of users of hypnotics and tranguillizers concerning pattern of use, indication and characteristics of users. A sample of 506 users out of nine general practices were divided in four categories: short-term use $(\leq 3$ months, occasional or episodic use) and long-term use (>3 months, episodic or continuous use). Taking hypnotic or tranquillizing drugs, one used mostly benzodiazepines. Most short-term users took their drug not longer than 2 months ( $92 \%$ ). The long-term users took in $42 \%$ of the cases their drug every day (continuous). The general practitioner himself or his colleague was the one who mostly started prescribing these drugs. There were more women than men in all investigated groups. In comparison with short-term users the long-term users had other social characte-ristics (higher age, more often single, not working and health insurance by the sick fund), and other personal characteristics (feeling more lonely, having other coping styles). Their experience with their mental and somatic health was less favourable and the problem list of their medical record showed more health problems. All users said that health problems (especially musculo-skeletall and circulatory problems) were more often the reason for using the drugs than social problems. There was almosit no change in pattern of use and complaints causing the use in both groups long-term users.

In comparison with short-term use, long-term use was associated with older age, reacting with depressive behaviour in case of problems, a higher score on the medicine addiction index, having problems with children or housing and being content with the drug effects. In compurison with long-term episodic use, continuous use was asscociated with a bigher score on the medicine addiction index, older age, lower education, having lost a dear person and a less favourable experience of somatic health.

\section{chapter 9}

The study presented in this chapter concerns adverse effects, satisfaction, dependency and stopping the use of these drugs. The opinions of users and their general practitioner are measured. All users reported very few side-effects. Most general practitioners reported dependency as. 
a harmful side effect in case of long-term use. Long-term users were more satisfied with their medicine than short-term users, especially the once-only category. Compared with short-term users, long-term users rated considerably higher on the medicine-addiction index. Compared with long-term episodic users, long-term continuous users scaled higher on "drug seeking behaviour". The greater part of the general practitioners reported that patients who asked for more or stronger benzodiazepines, got these. In only $1.7 \%$ of all cases the general practitioner reported not to change the prescription when such a request was made. According to the general practitioners, they motivated about $50 \%$ of long-term users to stop the use; about $25 \%$ of these patients might have tried to do so. Except for the long-term continuous users, all others reported they would be able to stop their use without professional help, if they wanted to.

\section{chapter 10}

Differences in psychosocial determinants of users and non-users of hypnotics and tranquillizers are reported in chapter 10 . A sample of 705 users out of 11 general practices had filled in a questionnaire and were compared with controls (non-users), matcht by practice, sex and age. The users were divided in short-term ( $\leq 3$ months) usiers, long-term-episodic users and longterm-continuous users (long-term use was defined as $>3$ months). In comparison with controls, during one year all users experienced more long-term life problems. They more often asked help for solving those problerns. For all persons we found that at the end of the study year average $75 \%$ of the problems was unsolved.

The short-term users had different characteristics in comparison with non-users: they were less content, had more health problems, more often asked for help in problems with neighbours and/or relational problems and had more psychological problems (especially surmenage) in their problem list. The episodic users showed a more depressive behaviour when coping with life-problems, they asked more often for help in relational problems or health problems, and their problem list contained mote psychological problems. The continuous users suffered more from somatic problems, were less happy, they had more often problems with children and/or losing a dear person, they more often asked for help for health problems. More psychological problems were found in their problem list. Only continuous users used more alcohol.

\section{chapter II}

Chapter 11 reports upon differences in somatic determinants of users and non-users of hypnotics and tranquillizers. The research population is the same as in chapter 10. About half of all users said that health problems were the cause of their drug use: short-term users especially mentioned musculo-skeletal and digestive problems; episodic and continuous users musculoskeletal and cinculatory problems. $76 \%$ of the latter asked their general practitioner for help in 
solving their health problems. Their main complaints were insomnia and feeling anxious, tense or nervous. Compared with non-users all users took more other medicaments and, connected to that, we found more diagnoses of adverse effects of medical treatment in their problem list (especially adverse effects of medical agents). The problem lists of all users contained more active problems. Comparing ICPC-chapters of the problem lists, we found no differences between short-term users and controls. The episodic users had more problems in the following chapters: digestive system, psychological problems and female genital system; the continuous users only differed as to the psychological chapter.

\section{chapter 12}

This chapter presents a study in 4 general practices. The general practitioners filled in a questionnaire about a sample of 295 long-term users of benzodiazepines. They were asked about their opinion on stopping the use of these drugs. The sample had several characteristics commonly found in the literature. Compared to the total general practice population there wene more women and elderly people. The level of education was lower in the sample than in the general population. The sample contained more people who were insured by the sick fund, more widowed and single people and more people living in a home for elderly people.

The general practitioners thought that for $43 \%$ of the sample it was indicated to stop using the benzodiazepines, but for $70 \%$ of this group he thought stopping was not feasible.

According to the general practitioners $11 \%$ of the long-term users were patients, who might be able to stop using. Predictive factors for bringing up the subject were 'duration of taking benzodiazepines' (using < 1 years) and 'marital status' (divorced people).

\section{chapter 13}

In this chapter several important results of our study are discussed:

-the comparison of the characteristics of users

-psychological and somatic determinants of users compared with non-users

-long-term users and their future use, from the point of view of their gencral practitioner.

Recommendations are given for daily practice in order to prevent long-term use and to monitor the group long-term users. We conclude with suggestions for further research. 
210 


\section{Dankwoord}

Allereerst dient in dit dankwoord te worden wermeld dat dit proefschrift niet had kunnen verschijnen zonder de bereidwilligheid van alle patiënten om eraan mee te werken. Vragenlijsten invullen over een onderwerp, dat veelal privacy-gevoelige kanten heeft, is geen sinecure. Bijzonder veel dank ben ik aan hen verschuldigd.

Als praktizerend huisarts onderzoek doen vraagt vaak tijd en aandacht gedurende je dagelijkse werkzaamheden in de praktijk. Ook voor mij bracht het verrichten van dit onderzoek onregelmatigheden met zich mee die aanspraak maakten op het management in de praktijk en van de assistentes Marion Frijns, Wilma Mullers-Smeets en Peggy Coenen-Wetzels de nodige inventiviteit vroeg. Ook werd vaak een beroep gedaan op de bereidheid en souplesse van de beide collegae in de praktijk, Giel Peeters en Anne-Marie Muysken-du Saar, mijn afwezigheid op te vangen, zodat de dagelijkse gezondheidszorg in de praktijk doorgang kon vinden. Giel, Anne-Marie, Marion, Wilma en Peggy hartelijk bedankt voor jullie steun.

In het verlengde hiervan is uiteraard ook veel dank verschuldigd aan de collegae van de deelnemende RNH-praktijken: P. Voorhoeve, G.J. van Schendelt, M. van Nunen, H. Paas, mw. M. van Venrooy en R. Helmers van het gezondheidscentrum Hoensbroek te Hoensbroek, B. Huijnen, P. Castermans en P. Stalenhoef van het gezondheidscentrum dr. van Kleef te Maastricht, dr. G. Beusmans en dr. W. Vierhout van het gezondheidscentrum de Hofhoek te Maastricht, H. Vlek, H. van Dam, P. Jansen en mw. A. van Kessel van het gezondheidscentrum Withuis te Venlo, Ph. Govaert en R. Leclercq te Stein, V. Kaiser en J. Veldhuizen te Eygelshoven, J. Ypma, J. Eussen en mw. C. Stuurman van het Medisch Centrum te Landgraaf, R. Panhuysen, P. Hulshof en mw. E. Guldemond-Hecker te Voerendaal, F. Soomers en mw. J. Soomers-Turlings te Kerkrade, F. Guldemond te Ubachsberg, J, van der .Ploeg te Kerkrade en V. Zwietering te Maastricht. Tevens wil ik in dit dankwoord de apothekers vermelden die bereid waren hun electronische dossiers voor ons open te stellen en voorselecties te maken van de onderzoekspopulaties: apotheek Pieters te Stein, apotheek Elsloo, apotheek Boswijk te Brumssum, apotheken Janssens en Martens te Hoensbroek, apotheken Heerlerheide en Ganzeweide te Heerlen, apotheek Prickartz te Voerendaal, apotheek Vonken te Simpelveld, apotheken Snijders, Maussen, Latour, Schönefeld en van Wersch te Kerkrade, apotheek Smithuis te Eygelshoven, apotheken Jaspers, Groeneveld, Paus, de Hessele, de stadsapotheek en VenloZuid te Venlo en apotheken v. Thoor, v. Turnhout, Malberg, Nazareth en Straver te Maastricht. 
De totstandkoming van dit proefschrift is de resultante van een inspanning die niet alleen door mij geleverd is. Er is met velerlei personen samengewerkt aan een aardig karwei. Mijn dank gaat naar hen allen uit.

In dit kader wil ik speciaal noemen:

prof. dr. A.J. Knottnerus, promotor. Beste André, de wijze waarop je mij begelleid hebt was zeer inspirerend. Het heeft me vaak verbaasd dat je zo snel belangrijke punten wist aan te geven en altijd enthousiasmerend was, zeker wat betreft het perspectief van het onderzoek.

dr. F.G.E.M. van der Horst en dr. R.F. van der Grinten, co-promotoren. Beste Frans en Remy, jullie hebben mijn werk begeleid op een enthousiaste, actieve manier. Vele concepten van de diverse hoofdstukken hebben jullie moeten lezen en wan commentaar voorzien. In het uiteindelijke resultaat heboen jullie een belangrijk aandeel geleverd, waarvoor hartelijk dank.

dr. A.D.H. Kester. Beste Amold op een rustige wijze gaf je adviezen toen het met de statistische analyses moeilijk werd.

M. Latour en K. Aretz. Beste Monique en Karin, jullie beiden zijn mijn steunpilaar geweest waar het de uitvoer van het onderzoek betrof, zowell in het veldwerk als ook bij de bewerking van de data in de vele analyses.

Voorts wil ik een aantal betrokkenen bedanken die mij in diverse onderdelen van mijn onderzoeksaktiviteiten geholpen hebben: Henri Plagge, Karin Poulsen en Cees de Geus bij de eerste oriëntatile, namelijk de baliereceptuur; in het kader van hun wetenschapsstage hebben Sabine Hofsommer en Annekien Jongbloet bijgedragen aan het resultaat van dit onderzoek; Theo Gubbels, George Beusmans en Harry Crebolder wisten het onderwerp van de klinische patientenbesprekingen uit te laten groeien tot een lezenswaardig hoofdstuk in dit proefschrift.

Willie de Bruyn wil ik bedanken voor het corrigeren wan mijn Nederlandse taal en Saskia Mol voor de correcties in de Engelstalige samenvattingen.

Uiteraard ben ik ook dank verschuldigd aan niet vermelde pesonen die ik in de wandelgangen gesproken heb.

Aan het eind van dit dankwoord wil ik mijn ouders bedanken voor hun inzet die mij de ruimte gaf om te kunnen studeren. Zij hebben de basis gelegd voor mijn bestaan als huisarts.

Tot slot lieve Sonja, bedankt woor de de wijze waarop je me op jouw karakteristieke manier de mogelijkheid gaf zo veel van onze gemeenschappelijke tijd aan dit onderzoek te kunnen besteden. Ywonne, Brigitte, en Mirjam jullie hebben, zeker de laatste twee jaar, ervaren dat ik well thuis was, maar niet bereikbaar. Opmerkingen van jullie kant als "maar dat heb ik toch al verteld" $\mathrm{k}$ wamen veelvuldig voor. Ik zal mijn aandacht nu ook weer op jullie kunnen richten. 


\section{Curriculum vitae}

Frans H.J.A. Vissers werd geboren op 30 augustus 1946 te Weustenrade (Klimmen/ Limburg). In 1966 na het behalen van het einddiploma gymnasium $\beta$ aan het Bisschoppelijk College te Sittard, begon hij zijn studie Geneeskunde aan de Kaiholieke Universiteit te Nijmegen, alwaar" hij in 1974 afstudeerde.

Na het vervullen wan de militaire dienst als militair arts bij de AFCENT te Brunssum vestigde hij zich medio 1976 als huisarts in de Masstrichtse wijk Heer in associatief verband met A.M.R Seelen. De gezamenlijke huisartspraktijk ging in 1977 op in het gezondheidscentrum Heer. In 1986 zette hij zijn werkzaamheden in het gezondheidscentrum voort in associatie met M.P.J.M.Peeters.

Sinds 1978 is hij part-time verbonden aan de capaciteitsgroep Huisartsgeneeskunde van de Universiteit Maastricht. 



\section{Bijlagen \\ behorende bij het proefschrift}

\section{Gebruik}

\section{van}

\section{slaap- en kalmeringsmiddelen in het dagelijks leven}

determinanten, gevolgen en de rol van de huisarts 
Bijlage Ia

uitnodigingsbrief aan patiënten voor deelname aan de eerste enquête 


\section{Bijlage Ia}

Geachte heer/mevrouw,

Zoals u waarschijnlijk we] weet werken wij samen met de universiteit in Maastricht. Aan de universiteit worden dokters opgeleid en vindt wetenschappelijk. onderzoek plaats. Om ervoor te zorgen dat dokters hun patiënten zo goed mogelijk kumnen helpen, is en blijft veel onderzoek nodig.

Soms is voor onderzoek ook hulp nodig van patiënten. Daarom ontvangt u deze brief. Wij zouden u willen vragen mee te doen aan een onderzoek. Het onderzoek gaat over het gebruik van geneesmiddelen. De onderzoekers, dokter F. Vissers en professor A. Knottnerus, willen nagaan hoe het komt dat sommige mensen geen en andere mensen soms of vaak kalmerende middelen of slaaptabletten gebruiken. Voor het onderzoek is het belangrijk om te weten hoe het met uw gezondheid is. Als u meedoet aan het onderzoek, zal de onderzoeker ons enkele vragen stellen over uw gezondheid. Uw apotheker zal gevraagd worden welke medicijnen u gebruikt.

Als u mee wilt doen, vult u dan de vragenlijst in. Het kost u ongeveer drie kwartier. Uw antwoorden op de vragen zullen vertrouwelijk behandeld worden. Bij dit onderzoek krijgen wij uw antwoorden niet onder ogen. $U$ stuurt de vragenlijst rechtstreeks naar de universiteit in de enveloppe. Een postzegel plakken is niet nodig. De onderzoekers krijgen alle gegevens anoniem, dat wil zeggen dat uw naam en adres bij de onderzoeker niet bekend is.

Ongeveer een maand nadat $u$ de vragenlijst heeft ingevuld krijgt de helft van de mensen die meedoen een tweede vragenlijst. De tweede vragenlijst zal ongeveer 30 minuten nemen om in te wullen.

Als u niet mee wilt doen aan het onderzoek, wilt u dan de eerste pagina van de vragenlijst, waar uw onderzoeksnummer opstaat, terugsturen in de enveloppe. U zult dan niet nog eens gevraagd worden om mee te doen.

Bij voorbaat dank voor uw medewerking.

Hoogachtend,

Uw huisarts(en) 
Bijlage $\mathrm{Ib}$

eerste patiënten-enquête

patiëntnummer.

\section{geneesmiddelen onderzoek}

in de

huisartspraktijk

Rijksuniversiteit Limburg

Vakgroep huisartsgeneeskunde

Randwyck, Maastricht 


\section{GENEESMIDDELEN ONDERZOEK}

\section{IN DE}

\section{HUISARTSPRAKTIJK}

Rijksuniversiteit Limburg

Vakgroep huisartsgeneeskunde

Te: Randwijck, Maastricht 

In deze vragenlijst worden U wragen gesteld over het gebruik van medikamenten in het afgelopen jaar (oktober 1992-oktober 1993).

De lijst bestaat uit drie soorten wragen. Van elk soort geven we hieronder een voorbeeld.

1. Het gekozen antwoord dient aangekruist te worden.

Per vraag 1 antwoord aankruisen, tenzil dit anders. vermeld wordt

Voorbeeld:

Gebruikt U geneesmiddelen?

$1 \square$ nee

$2 \mathbb{1}$ ja

2. Het antwoord dient $u$ op de stippellijn in te vullen:

Voorbeeld:

Hoeveel tabletten gebruikt U per dag? 3 .

3. Het gekozen antwoord dient aangekruist te worden:

Voarbeeld:

zelden vams vak

kunt U uW gevoelens tonen

$1 \square$

3

Zoudt $U$ de vragen willen beantwoorden in de volgorde zoals ze in de vragenlijst staan? Dit is van belang omdat in de tekst aanwijzingen zijin opgenomen. Deze aanwijzingen geven aan welke wragen in uw geval kunnen worden owergeslagen. Indien $U$ de vragen in de verkeerde volgorde invult, mist $U$ deze aanwijzingen.

Alle door $U$ in deze enquête verstrekte gegevens zullen volstrekt vertrouwelijk behandeld worden, ze vallen onder het medisch geheilm. Ook worden de resultaten van deze enquête anoniem verwerkt.

Mochten er onduidelijkheden zijn, dan kunt $U$ overdag inlichtingen krijgen bij: Mevr. M. Lattour, onderzoeksassistente tel. $043-882320$

of

Dhr. F. Vissers, huisarts/onderzoeker tel. 043-611000 (praktijknummer) 



\section{ALGEMEEN}

1. Wat is uw geboortedatum?

dag.... maand.... jaar....

2. Wat is uw geslacht?

$1 \square \operatorname{man}$

$2 \square$ vrouw

\section{NU VOLGEN EEN AANTAL VRAGEN OVER UW WERKSITUATIE}

3. Wat is nu op $U$ van toepassing?

\section{Meerdere antwoorden zijn mogelijk}

Wilt $U$ tevens het jaar invullen vanaf wanneer het gekozen antwoord op $U$ van toepassing is?

$1 \square$ ik heb nooit betaald werk verricht

$2 \square$ ik heb betaald werk (volledige of part-time baan) vanaf 19... (jaar)

$3 \square$ ik ben werkloos (geheel of gedeelltelijk) vanaf $19 .$. (jaar)

$4 \square$ ik ben arbeidsongeschikt (geheel of gedeeltelijk) vanaf $19 \ldots$ (jaar)

$5 \square$ ik ben gepensioneerd of in de vut

$6 \square$ ik ben huisvrouw of -man vanaf $19 . .$. (jaar)

$7 \square$ anders, namelijk

4. Bent $U$ als zelfstandige werkzaam, eventueel gedeeltelijk?
$1 \square$ nee
$2 \square$ ja, vanaf $19 \ldots$.. (jaar)

5. Bervt $U$ in loondienst, eventueel gedeeltelijk?
$1 \square$ nee
$2 \square$ ja, vanaf $19 \ldots$ (jaar)

6. Nu volgt een vraag over uw huidige werk of wanneer $U$ geen betaald werk meer verricht uw laatste werk, voor zover het oktober 1992 tot oktober 1993 betreft.

- werkte U uitsluitend overdag

- werkte U uitsluitend 's avonds of 's nachts

- werkte $U$ in ploegendienst

$1 \square$ nee $2 \square$ ja
$1 \square$ nee $2 \square$ ja
$1 \square$ nee $2 \square$ ja


7. Wilt U hieronder omschrijwen welke medikamenten (zelf gekocht of gekregen wan een arts of andere hulpverlener) $U$ gebruikt hebt in de periode van oktober 1992 - oktober 1993. Wilt $U$ per medikament de naam noteren, aangeven of $U$ het nog steeds gebruikt, en voor welke klacht of ziekte U dit gebruikt?

naam

Med. 1:

Med. 2:

Med. 3:

Med. 4:

Med. 5:

Med. 6:

Med. 7:

Med. 8:

Mled. 9:

Med. 10:

Med. 11:

Med. 12:

Med. 13:

Med. 14:

Med. 15:

Medl 16:

Med. 17 :

Med. 18:

Med. 19:

Med. 20:

nog in klacht/ziekte
gebruik
(ja/nee)


Er volgen nu enkele uitspraken over kontakten met andere mensen.

We willen met deze vraag nagaan of het hebben van kontakten met andere mensen inwloed heeft op probleemverwerking. Wilt $U$ van elk van de uitspraken het antwoord aankruisen dat op $U$ van toepassing is?

Bij het antwoord gaat het orn uw ervaring van de laatste tijd.

De antwoorden zijn als volgt onderverdeeld:

ja! $\quad=$ precies op mij van toepassing

ja $\quad=$ grotendeels op mij van toepassing

min/meer $=$ min of meer op mij van toepassing

nee $\quad=$ in beperkte mate op mij van toepassing

nee! helemaal niet op mij van toepassing

ja! ja min/ nee nee!

9. Er is altüjd wel iemand in mijn omgeving bij wie ik met mijn dagelijkse problemen terecht kan $1 \square \quad 2 \square \quad 3 \square \quad 4 \square \quad 5 \square$

10. $\| \mathrm{k}$ mis een echte goede vriendlin

$2 \square \quad 3 \square \quad 4 \square \quad 5 \square$

11. Ik ervaar een leegte om mij heen

1

2

3

4

5

12. Er zijn genoeg mensen op wie $i k$ in geval van narigheid

kan terugvallen

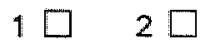

3

4

$5 \square$

225

13. I $\mathrm{k}$ mis gezelligheid om me heen

1

2

3

4

5

14. Ik vind mijn kring van kennissen te beperkt

9

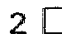

$3 \square$

4

5

15. Ik heb weel mensen op wie ik volledig kan vertrouwen

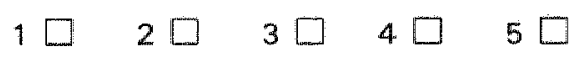

16. Er zijn genoeg mensen met wie ik mij verbonden woel

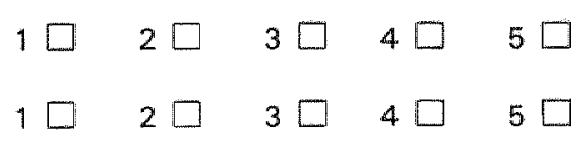

17. Ik mis mensen om mij heen

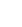

18. Vaak voel ik mij in de steek gelaten

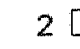

3

4.

5

19. Wanneer ik daar behoefte aan heb, kan ik altijd bij mijn vrienden terecht 
Hieronder volgen enkele vragen over lichamelijke en psychische klachten. Deze vragen zijn bedoeld om inzicht te krijgen in hoe $U$ uw eigen gezondheid ervaart. Wilt $U$ voor ieder van de hier onderstaande klachten aangeven in hoeverre $U$ er last van hebt door het antwoord aan te kruisen dat het meest op $U$ van toepassing is. Het gaat daarbij steeds om hoe $U$ zich gedurende de afgelopen week met vandaag erbij woelde.

Hebthad u last van:

$\begin{array}{cl}\begin{array}{c}\text { helemaal } \\ \text { niet }\end{array} & \text { neen } \\ \text { betje } & \begin{array}{l}\text { heel } \\ \text { erg }\end{array}\end{array}$

20. hoofdpijn

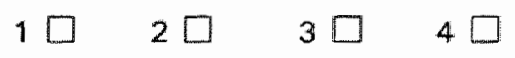

21. nare gedachten of ideeën niet kwijt kunnen raken

22. duizeligheid

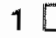

2

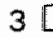

4

23. piekeren over slordigheid

1

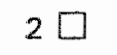

3

4

$1 \square \quad 2 \square$

$3 \square$

$4 \square$

24. je gemakkelijk verveeld of geïriteerd voelen

$\square$

$2 \square$

$3 \square$

4

25. moeilijk kunnen praten ais je opgewonden bent

$1 \square \quad 2 \square$

$3 \square$

$4 \square$

26. weinilg puf (energie)

hebben

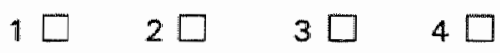

27. denken om er een eind aan te maken

28. verstrikt zijn of zich gevangen voellen

29. woede uitbarstingen die je niet in de hand hebt

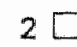

\title{
3
}

4

30. jezelf iets verwijten

\author{
1
}

$2 \square$

3

4

31. pijn onder in de rug

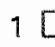

$2 \square$

3

$4 \square$

32. je gauw gekwetst voelen

1

2

$3 \square$

4

33. steeds anderen moeten vragen wat je moet doen

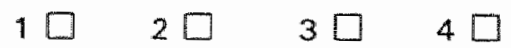


(vervolg)

Hebt/had u last van:

$\begin{array}{cll}\begin{array}{c}\text { helemaal } \\ \text { niet }\end{array} & \begin{array}{l}\text { een } \\ \text { beetje }\end{array} & \text { nogal heel } \\ \text { erg }\end{array}$

34. het gevoel dat anderen

je niet begrijpen of

onaardig vinden

$1 \square \quad 2 \square \quad 3 \square \quad 4$

35. het gevoel dat anderen onvriendelijk zijn of je niet mogen

$1 \square \quad 2 \square \quad 3 \square \quad 4 \square$

36 . iets langzaam moeten doen om er zeker van te zijn dat je het goed doet

37. hartkloppingen

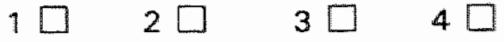

250

38. misselijkheid

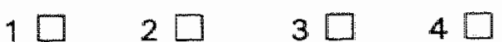

39. je tegenover anderen de mindere voelen

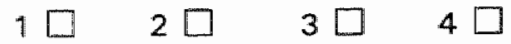

40. pijnlijke spieren

1

2

3

4

253

41. moeilijk adem kunnen krijgen

$1 \square \quad 2 \square \quad 3 \square \quad 4 \square$

42. verdoofd of tintelend gevoel in je lichaam

43. je wanhopig voelen over de toekomst

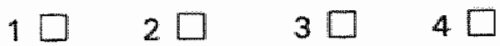

44. je moeilijk kunnen concentreren 
Mensen reageren vaak heel werschillend als zij met problemen of onplezierige gebeurtenissen te maken krijgen. Wat men in een bepaald geval doet hangt sterk af van de aard van het probleem of de gebeurtenis, en de ernst ervan. Tach reageert men als men te maken krijgt met problemen, OVER HET ALGEMEEN, wat vaker op de ene dan op de andere manier.

Hieronder staan een aantal beschrijvingen die aangeven wat men zoal kan denken of doen als er problemen zijn. Wilt $u$ achter iedere zin aangeven hoe vaak $u$ in het algemeen op de beschreven manier reageert. $U$ kunt dit doen door bij iedere zin eén van de cijfers aan te kruisen. Er zijn geen goede of foute antwoorden. Wilt U S.V.p. geen zinnen overslaan.

Als er onplezierige gebeurtenissen zijn,

$\begin{array}{ll}\begin{array}{l}\text { zelden soms vaak zeer } \\ \text { of nooit }\end{array} & \begin{array}{l}\text { vaak } \\ \text { val }\end{array}\end{array}$

Kun je:

45. je bedenken dat er nog wei ergere dingen kunnen gebeuren

$\begin{array}{llll}1 \square & 2 \square & 3 \square & 4 \square \\ 1 \square & 2 \square & 3 \square & 4 \square \\ 1 \square & 2 \square & 3 \square & 4 \square \\ 1 \square & 2 \square & 3 \square & 4 \square \\ 1 \square & 2 \square & 3 \square & 4 \square\end{array}$

46. proberen je te ontspannen

47. je volledig afzonderen van anderen

48. je ergernis laten blijken

49. de zaken somber inzien

50. je met andlere dingen bezighouden om niet aan een probleem hoeven te denken

$1 \square \quad 2 \square \quad 3 \square \quad 4$

51. laten zien dat je kwaad bent op degene die verantwoordelijk is voor het probleem

$2 \square$

3

4

52. toegeven om moeilike situaties te vermijden

$1 \square \quad 2 \square \quad 3 \square \quad 4$

53. je neerleggen bij de gang van zaken

54. je zorgen met iemand delen

1

$1 \square \quad 2 \square$

3

$4 \square$

55. direkt ingrijpen als er moeilijkheden zijn 
(vervolg)

zelden soms vaak zeer

Als er onplezierige gebeurtenissen zijn.

kun je:

56. tegen jezelf zeggen dat het allemaal wel zal meevallen

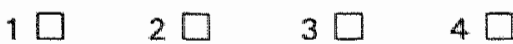

57. problemen als een uitdaging zien

1

$2 \square \quad 3 \square$

4

58. je zorgen tijdelijk verdrijven door er even uit te gaan

$1 \square \quad 2 \square \quad 3 \square \quad 4 \square$

59. de kat uit de boom kijken

$1 \square \quad 2 \square \quad 3 \square \quad 4 \square$

60. spanningen proberen te verminderen door bijv. meer te roken, drinken, eten of bewreging nemen

$1 \square \quad 2 \square \quad 3 \square \quad 4 \square$

61. afleiding zoeken

$1 \square \quad 2 \square \quad 3 \square \quad 4 \square$

62. een problleem van alle kanten bekijken

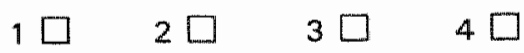

63. moeilijke situaties zoveel mogelijk uit de weg gaan

$1 \square \quad 2 \square \quad 3 \square \quad 4 \square$

64. optimistisch blijven over de toekamst

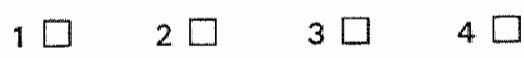

65. kallm blijven in moeilijke situaties

$1 \square \quad 2 \square \quad 3 \square \quad 4 \square$

66. verschillende mogelijkheden bedenken am een probleem op te lossen

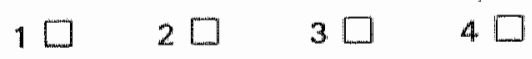

67. doelgericht te werk gaan om een probleem op te lassen

68. piekeren over het verleden

$\begin{array}{cccc}1 \square & 2 \square & 3 \square & 4 \square \\ 1 \square & 2 \square & 3 \square & 4 \square \\ & & & \\ 1 \square & 2 \square & 3 \square & 4 \square\end{array}$

69. opgewekt gezelschap zoeken als je je zorgen maalkt of van streek bent 
8

(vervolg)

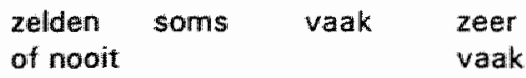

Als er onplezierige gebeurtenissen zijn,

kun je:

70. proberen je te onttrekken aan de situatie

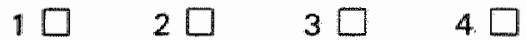

71. je spanningen afreageren

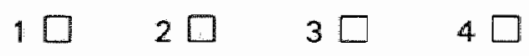

72. wachten op betere tijden

$\begin{array}{lll}1 \square & 2 \square & 3 \square\end{array} \square$

73. iemand om hulp vragen

$1 \square \quad 2 \square \quad 3 \square \quad 4 \square$

74. rustgevende middelen gebruiken alls je je gespannen voelt of nerveus bent

$1 \square \quad 2 \square \quad 3 \square \quad 4 \square$

75. wegvluchten in fantasieẽn

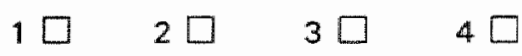

76. de zaken eerst op een rij zetten

$1 \square \quad 2 \square \quad 3 \square \quad 4 \square$

77. je geheel en al in beslag laten nemen door problemen

$1 \square . \quad 2 \square \quad 3 \square \quad 4 \square$

78. aan andere dingen denken die miets met het probleem te maken hebben

$1 \square \quad 2 \square \quad 3 \square \quad 4 \square$

79. op een of andere manier proberen je wat prettiger te voelen

$1 \square \quad 2 \square \quad 3 \square \quad 4 \square$
eens moeilijkheden hebben

$1 \square \quad 2 \square \quad 3 \square \quad 4 \square$

81. je bedenken dat na regen zonneschijn komt

$1 \square \quad 2 \square \quad 3 \square \quad 4 \square$

83. troost en begrip zoeken

$1 \square \quad 2 \square \quad 3 \square \quad 4 \square$

84. moeilijkheden over je heen laten komen 
(wervolg)

zelden soms vaak $\begin{aligned} & \text { zeer } \\ & \text { vaak }\end{aligned}$
of nooit

Als er onplezierigle gebeurtenissen zijun.

kun je:

85. de humoristische kant van problemen zien

86. laten merken dat je ergens mee zit

87. met vrienden of familieleden thet probleem bespreken

88. de zaak op zijn beloop laten

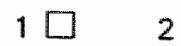

2

3

4

89. je niet druk maken: meestal komt alles op zijn pootjes terecht

90. je niet in staat voelen om iets te doen

91. jezelf moed inspreken bij moeilijkheden

$1 \square \quad 2 \square \quad 3 \square \quad 4 \square$

\section{NU VOLGEN ENKELE VRAGEN OVER UW GEWOONTES}

\section{Rookt U?}

Indien ja, wilt $U$ bij het soort dat $U$ gebruikt aangeven hoeveel per dag? Eventueel meerdere hokjes aankruisen

$1 \square$ nee

$2 \square$ ja ik rook ..... sigaretten/shaggies per dag .........> ga door naar wraag 94

$3 \square$ ja, ik rook ..... sigaren per dag ….............. $>$ ga door naar vraag 94

$4 \square$ ja, ik rook pijpen per dag $>$ ga door naar vraag 94

93. Indien $U$ niet rookt, kunt $U$ aangeven of $U$ in het verleden gerookt hebt?
$1 \square$ nee, ik heb nooit gerookt
$2 \square$ ja, ik ben gestopt in $19 .$. 
94. Drinkt U koffie?

Indien ja, wilt U dan ook aangeven hoeveel kopjes U per dag drinkt?

$1 \square$ nee

2. $\square$ ja, ik drink ..... kopje(s) koffie per dag

95. Indien $U$ geen koffie drinkt, kunt $U$ dan aangeven of $U$ in het verleden koffie gedronken hebt?

$1 \square$ nee, ik heb nooit koffie gedronken

$2 \square$ ja, ik ben gestopt in $19 .$.

96. Gebruikt U allcoholische dranken?

$1 \square$ nee

$2 \square$ ja -.....-.> ga door naar wraag 98

97. Indien $U$ geen alcoholhoudende dranken gebruikt, kunt $U$ aangeven of $U$ in het verleden alcoholhoudende dranken gebruikt hebt?

$1 \square$ nee, nooit alcoholhoudende dranken gebruikt $\ldots>$ ga door maar vraag 104

98. Gebruikt $U$ well eens alcohol om $U$ ontspannen te voelen of goed te kunnen slapen?
$1 \square$ nee, nooit
$2 \square$ ja, een enkelle keer
$3 \square$ ja, regelmatig
$4 \square$ ja, waak
$5 \square$ ja, heel vaak

99. Hebt $U$ het afgelopen jaar het gevoel gehad dat $U$ het gebruik van alcohol zou moeten stoppen/minderen?
$1 \square$ heel vaak
$2 \square$ vaak
$3 \square$ soms
4. $\square$ nee 
100. Raakte $U$ afgelopen jaar wel eens geïriteerd door aanmerkingen wan anderen op uw gebruik van alcohol?

$1 \square$ heel vaak

$2 \square$ vaak

$3 \square$ soms

$4 \square$ nee

101. Hebt $U$ zich afgelopen jaar wel eens vervelend of schuldig gevoeld over uw gebruik van alcohol?

$1 \square$ heel vaak

$2 \square$ vaak

$3 \square$ soms

$4 \square$ nee

102. Is het het afgelopen jaar voorgekomen dat $U$ wakker geworden bent en dat $U$ behoefte had om een glas alcoholhoudende drank te nemen.

$1 \square$ heel vaak

$2 \square$ vaak

$3 \square$ soms

$4 \square$ nee

103. Vindt $U$ dat $U$ in het verledien een probleem heeft gehad met te veel alcohol gebruik?
$1 \square$ ja
$2 \square$ twijfel
$3 \square$ nee
$4 \square$ weet niet

104. Maakt iemand $U$ wel eens opmerkzaam op het feit dat $U$ in uW slaap: $U$ kunt hier meerdere antwoorden geven
$1 \square$ veel snurkt
$2 \square$ schopt of trekt met uw benen
3. $\square$ uw ademhaling stokt
4. $\square$ niet van toepassing 
105. Wilt U hier uw lichaamsgewicht en lengte invullen?

gewicht: $\ldots . . . . \mathrm{kg}$

lengte: $\ldots . . . . \mathrm{cm}$

De volgende 7 vragen worden U gesteld om na te gaan hoe uw mening in het algemeen is over slaap-en kalmeringsmiddelen.

Wat vindt $U$ van de vollgende witspraken?

$\begin{array}{llll}\text { helemal enigszins enigszins helemaal } & \text { hel } \\ \text { mee eens mee eens mee } & \text { mee } \\ & & \text { oneens oneens }\end{array}$

106. Kalmerende middelen doen de mensen meer kwaad dan goed 1

2.

3

$4 \square$

107. Kalmerende middelen helpen vaak goed om spanningen te verlichten

2

3

4

108. lemand zou pas als laatste redmiddel zijn toevlucht tot kalmerende middelen moeten nemen

1

$2 \square$

3

4

109. Men kan beter met behulp van een slaapmiddel slapen dian slecht slapen

1

$2 \square$

3

4

110. Kalmerende middelen zijn verdavende middelen

2

$3 \square$

4.

111. Men kan beter een kalmerend middel innemen dan de dag gespannen en zenuwachtig moeten doorkomen

2

3

4

112. Slä̌p-en kalmeringsmiddelen zijn een noodzakelijk kwaad

1

2

3

$4 \square$ 
ledereen heeft well eens problemen in zijn of haar leven die na een kortere of langere tijd al dan niet apgelost worden. Om inzicht te krijgen in thet soort problemen waarmee mensen zoal te maken hebben, hebben we een aantal vragen geformuleerd. Geef per vraag aan of en in welke mate een of meer van deze problemen op U van toepassing zijn (of zijn geweest), van oktober 1992 tot oktober 1993. Kruis per vraag het antwoord aan dat uw situatie het beste weergeeft. Als het probleem niet op $U$ van toepassing is, kruist $U$ dan het antwoord "geen" aan, en ga dan door naar het volgend probleem.

113. Hebt/had $U$ van oktober " 92 tot oktober " 93 problemen:

Pr 1. op het werk of met huishoudielijk werk

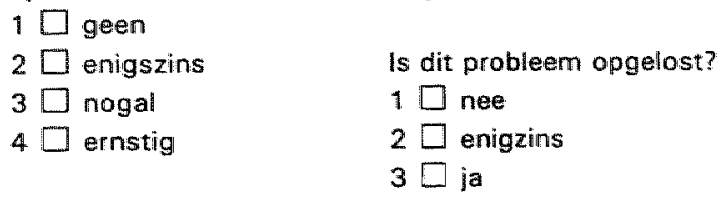

Hebt $U$ bij de oplossing hullp gevraagd?

$1 \square$ nee, geen hulp gevraagd

2. $\square$ ja, hulp gevraagd aan:
$1 \square$ huisarts
$2 \square$ specialist
3. $\square$ maatschappelijk werk
$4 \square$ geestelijke gezondheidszorg
$5 \square$ anders

Pr 2. op school of met de studie
$1 \square$ geen
$2 \square$ enigszins
$3 \square$ nogal
4. $\square$ ernstig

Is dit probleem opgelost?

$1 \square$ nee

$2 \square$ enigzins

$3 \square$ ja

Hebt $U$ bij de oplossing hulp gevraagd?

$1 \square$ nee, geen hulp gevraagd

$2 \square$ ja, hulp gevraagd aan:
$1 \square$ thuisarts
$2 \square$ specialist
$3 \square$ maatschappelik werk
$4 \square$ geestelike gezondheidszorg
$5 \square$ anders 
113. Hebt/had $U$ van oktober' 92 tot oktober " 93 problemen:

Pr 3. op financieel gebied
$1 \square$ geen
$2 \square$ enigszins
$3 \square$ nogal
4. $\square$ ernstig

Is dit probleem opgelost?

$1 \square$ nee

$2 \square$ enigzins

$3 \square$ ja

Hebt $U$ bill de oplossing hulp gevraagd?

$1 \square$ nee, geen hulp gewraagd

$2 \square \mathrm{ja}$, hulp gevraagd aan:
$1 \square$ huisarts
$2 \square$ specialist
$3 \square$ maatschappelijk werk
$4 \square$ geestelijke gezondheidszorg
$5 \square$ anders

Pr 4. met husisvesting
$1 \square$ geen
$2 \square$ enigszins
$3 \square$ nogal
4. $\square$ ernstig

Is dit probleem opgelost?

$1 \square$ nee

$2 \square$ enigzins

$3 \square$ ja

Hebt $U$ bij de oplossing hulp gevraagd?

$1 \square$ mee, geen hulp gevraagd

$2 \square$ ja, hulp gevraagd aan:
$1 \square$ huisarts
$2 \square$ specialist
$3 \square$ maatschappelijk werk
4. geestelijke gezonoheidszorg
$5 \square$ anders

Pr 5. met de lleefsituatie in uw buurt of straat
$1 \square$ geen
$2 \square$ enigszins
30 nogal
$4 \square$ ernstig

Is dit probleem opgelost?

$1 \square$ nee

$2 \square$ enigzins

3. $[$ ja

Hebt U bij de oplossing hulp gevraagd?

$1 \square$ nee, geen hulp gevraago

$2 \square$ ja, hulp gevraagd aan:

$1 \square$ huisarts

$2 \square$ specialist

$3 \square$ maatschappelijk werk

4. geestelijke gezondheidszorg

$5 \square$ andiers 
113. Hebt/had U van oktober "92 tot oktober "93 problemen:

Pr 6. op sexueel gebied

$1 \square$ geen

$2 \square$ enigszins

Is dit probleem opgelost?

$3 \square$ nogal

$1 \square$ nee

$4 \square$ errustig

$2 \square$ enigzins

$3 \square$ ja

Hebt $U$ bij de oplossing hulp gevraagd?

$1 \square$ nee, geen hulp gevraagd

$2 \square$ ja, hulp gevraagd aan:
$1 \square$ huisarts
$2 \square$ specialist
$3 \square$ maatschappelijk werk
$4 \square$ geestelijke gezondheidszorg
$5 \square$ anders

Pr 7. met godsdienst of gelloof
$1 \square$ geen
$2 \square$ enigszins
$3 \square$ nogal
$4 \square$ ernstig

Is dit probleem opgrelost?

$1 \square$ nee

$2 \square$ enigzins

$3 \square$ ja

Hebt $U$ bij de oplossing hulp gevraagd?

$1 \square$ nee, geen hulp gevraagd

$2 \square$ ja $\mathrm{a}_{\mathrm{r}}$ hulp gevraagd aan:
$1 \square$ huisarts
$2 \square$ specialisit
$3 \square$ maatschappelijk werk
4. Geestelijke gezondheidszorg
$5 \square$ anders

402

403

404

405

400

407

408

$4.09 \cdot 4.10$

Pr 8. met malatschappelijke ontwikkelingen
$1 \square$ geen
$2 \square$ enigszins
$3 \square$ nogal
$4 \square$ ernstilg

Is dit probleem opgelost?

$1 \square$ nee

2 . enigzinsi

$3 \square$ ja

Hebt $U$ bij de oplossing hulp gevraagd?

$1 \square$ nee, geen hulp gevraagd

$2 \square$ ja, hulp gevraagd aan:
$1 \square$ huisarts
2. $\square$ specialist
$3 \square$ maatschappelijk werk
$4 \square$ geestelijke gezondheidlszorg
$5 \square$ anders 
113. Hebt/had U van oktober '92 tot oktober '93 problemen:

Pr 9. met uw partner
$1 \square$ geen
$2 \square$ enigszins
$3 \square$ nogal
$4 \square$ ernstig

Is dit probleem opgelost?

$1 \square$ nee

$2 \square$ enigzins

$3 \square$ ja

Hebt $U$ bij de oplossing hulp gevraagd?

$1 \square$ nee, geen hulp gevraagd

$2 \square$ ja hulp gevraagd aan:
$1 \square$ huisarts
2 specialist.
$3 \square$ maatschappelijk werk
$4 \square$ geestelijke gezondheidszorg
$5 \square$ anders

Pr 10. met uw ouders
$1 \square$ geen
$2 \square$ enigszins
$3 \square$ nogal
$4 \square$ ernstig

Is dit probleem opgelost

$1 \square$ nee

$2 \square$ enigzins

$3 \square$ ja

Hebt $U$ bil de oplossing hulp gevraagd?

$1 \square$ nee, geen hulp gevraagd

$2 \square \mathrm{ja}_{\text {s }}$ hulp gevraagd aan:
$1 \square$ huisarts
$2 \square$ specialist
$3 \square$ maatschappelijk werk
$4 \square$ geestelijke gezondheidszorg
$5 \square$ anders

Pr 11. met uw kind/eren)
$1 \square$ geen
$2 \square$ enigszins
$3 \square$ nogal

Is dit probleem opgelost?

$1 \square$ neve

$2 \square$ enigzins

$3 \square$ ja

Hebt $U$ bij de oplossing hulp gevraagd?

$1 \square$ nee, geen hulp gevraagd

$2 \square$ ja, hulp gevraagd aan:
$1 \square$ huisarts
21 specialist
$3 \square$ maatschappelijk werk
$4 \square$ geestelijke gezondheidsizorg
$5 \square$ anders 
113. Hebt/had $U$ van oktober ' 92 tot oktober ' 93 problemen:

Pr $12 . \quad$ met uw schoonouders
$1 \square$ geen
$2 \square$ enigszins
$3 \square$ nagal
$4 \square$ ernstig

Is dit probleem opgelost?
$1 \square$ nee
$2 \square$ enigzins
$3 \square$ ja

Hebt U bij de oplossing hulp gevraagd?

$1 \square$ nee, geen hulp gevraagd

2. $\square \mathrm{ja}$, hulp gevraagd aan:
$1 \square$ huisarts
$2 \square$ specialist
3 $\square$ maatschappelijk werk
4 geestelijke gezondheidszorg
$5 \square$ anders

Pr 13. met uw broers/zusters
$1 \square$ geen
$2 \square$ enigszins
$3 \square$ nogal
$4 \square$ ernstig

Is dit probleem opgelost?
$1 \square$ nee
$2 \square$ enigzins
$3 \square$ ja

456

457

Hebt $U$ bij de oplossing hulp gevraagd?

$1 \square$ nee, geen hulp gevraagid

$2 \square \mathrm{ja}_{4}$ hulp gevraagd aan:
$1 \square$ huisarts
$2 \square$ specialist
$3 \square$ maatschappelijk werk
$4 \square$ gleestelijke gezondheidszorg
$5 \square$ anders

458

45 s

$46 C$

46.

4.6:

463.46

Pr 14. met mensen in uw buurt
$1 \square$ geen
$2 \square$ enigszins
$3 \square$ nogall
$4 \square$ ernstig

Is dit probleem opgelost?

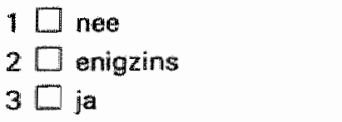

Hebt $U$ bil de oplossing huip gevraagd?

$1 \square$ nee, geen hulp gevraagd

$2 \square$ jal, hulp gevraagd aan:
$1 \square$ huisants
$2 \square$ specialist
$3 \square$ maatschappelijk werk
$4 \square$ geestelijke gezondheidszorg
$5 \square$ anders 
113. Hebt/had U van oktober' 92 tot oktober '93 problemem:

Pr 15. met vrienden of kennissen
1 geen
$2 \square$ enigszins
Is dit probleem opgelost?
$3 \square$ nogal
4. $\square$ ernstig
$1 \square$ nee
2 I enigzins
$3 \square$ ja

Hebt $U$ bij de oplossing hulp gewraagd?

$1 \square$ nee, geen hulp gevraagd

$2 \square$ ja, hulp gevraagd aam:
$1 \square$ huisarts
$2 \square$ specialist
$3 \square$ maatschappelink werk
$4 \square$ geestelijke gezondheidszorg
$5 \square$ anders

Pr 16. In kontakten met anderen
1 geen
$2 \square$ enigszinis
$3 \square$ nogal
4. Dernstig

Us dit probleem opgelost?

1 Gine

2 enigzins

$3 \square$ ја

Hebt U bij de oplossing hulp gevraagl?

$1 \square$ nee, geen hulp gevraagd

2 Ija, hulp gevraagd alan:
$1 \square$ huisarts.
$2 \square$ specialist
$3[$ maatschappelijk werk
$4 \square$ geestelijke gezandheidszorg
$5 \square$ anders

Pr 17. met het verlies van een persoon die U dierbaar was Apartner, ouder, kind, vriend - $\square$ goen

$2 \square$ enigszims

Is dit probleem opgelost?

$3 \square$ nogal

1 nee

$4 \square$ ernstig

$2 \square$ enigzins

$3 \square$ ja

Hebt $U$ bij de oplossing hulp gewragad?

$1 \square$ nee, geen hulp gevraagd

$2 \square$ ja, hulp gevraagd aan:
$1 \square$ huisarts
$2 \square$ specialist
$3 \square$ maatschappelijk werk
4 geestelijke gezondheidszorg
$5 \square$ anders 
113. Hebthad U van oktober " 92 tot oktober " 93 problemen:

Pr 18. met de verzorging van een chronisch zieke of en invalide thuis

$1 \square$ geen

$2 \square$ enigszins

Is dit probleem opgelost?

3. $\square$ nogal

$1 \square$ nee

4. $\square$ ernstig

$2 \square$ enigzins

$3 \square$ ja

Hebt $U$ bij de oplossing hulp gevraagd?

$1 \square$ nee, geen hulp gevraagd

$2 \square$ ja, hulp gevraagd aan:
$1 \square$ husisarts
2 . specialist
$3 \square$ maatschappelijk werk
4. geestelijke gezondheidszorg
5. $\square$ anders

Pr 19 . met eigen gezondheid
$1 \square$ geen
$2 \square$ enigszins
$3 \square$ nogal
$4 \square$ ernstig
Is dit probleem opgelost?
$1 \square$ nee
$2 \square$ enigzins
$3 \square$ ija

Hebt $U$ bij de oplossing hulp gevraagd?

$1 \square$ nee, geen hulp gevraagd

$2 \square$ ja, hulp gevraagd aan:
1 L huisarts
$2 \square$ specialist
$3 \square$ maatschappelijk werk
$4 \square$ geestelijke gezondheidszorg
$5 \square$ anders

Pr 20. Zijn er nog problemen die U niet in voorgaande opsomming kunt onderbrengen? $1 \square$ neve 
Hoe beoordeelt U uW gezondheid op lichamelijk en geestelijk niveau?

114. Hoe beoordeelt $U$ uw lichamelijk functioneren?
$1 \square$ zeer slecht
$2 \square$ slecht
$3 \square$ matig
4. $\square$ goed
$5 \square$ zeer goed

115. Hoe beoordeelt $U$ uw psychisch/gieestelijk functioneren?
$1 \square$ zeer silecht
$2 \square$ slecht
$3 \square$ matig
4. $\square$ goed
$5 \square$ zeer goed

116. Hoe gelukkig voelde $U$ zich de laatste maand alles bij elkaar genomen?
$1 \square$ zeer gelukkig
$2 \square$ gelukkig
$3 \square$ niet gelukkig/niet ongelukkig
4. $\square$ ongelukkig
$5 \square$ zeer ongelukkig

117. Hoe tevreden was $\mathrm{U}$ de laatste maand, alles bij elkaar genomen?
$1 \square$ zeer tevreden
$2 \square$ tevreden
$3 \square$ niet tevreden/niet ontevreden
4. $\square$ ontevreden
$5 \square$ zeer ontevreden

118. Zoals mensen een idee kunnen hebben over de kwaliteit van bijvoorbeeld fruit of wijn, zo kunnen ze ook een idee hebben over de kwaliteit wan hun leven. Deze kan hoog of laag zijn, of ergens tussen in. Zoudt $U$ op de lijn hieronder aan willen geven waar $U$ windt dat de kwaliteit wan UW leven lag in de periode van oktaber 1992 tot oktober 1993. U doet dat door een kruisje $(X)$ te zetten op die plaats op de ijn die overeenkomt met hoe $U$ de $k$ waliteit van uw leven ervaart. 
Het kan gebeuren dat, nadat de door $U$ ingevulde vragenlijst door ons gelezen is, er nog onduidelijkheden zijn. Windt $U$ het goed dat in dat geval telefonisch kontakt met U wordt opgenomen?

O ja, mijn telefoonnummer is:

O nee

HARTELIJK DANK VOOR HET INVULLEN VAN DE VRAGENLIJST.

Voor het onderzoek kan het van belang zijn dat over een bepaald geneesmiddel dat $U$ het afgelopen jaar gebruikt hebt, nog enige vragen worden gesteld. Als $U$ daarvoor in aanmerking komt zullen wij $U w$ huisarts(en) verzoeken $U$ nog een vragenlijst over dat geneesmiddel toe te sturen. 

Bijlage Ila

uitnodigingsbrief aan patiënten voor deelname aan de tweede enquête 
Bijlage IIa

Geachte heer/mevrouiw,

Drie maanden geleden hebt u een vragenlijst ontvangen over het gebruik van geneesmiddelen. In de brief bij de vragenlijst stond toen al dat a misschien nog een vragenlijst zou ontvangen. Voor het onderzoek is deze tweede vragenlijst erg belangrijk. Uit uw antwoorden in de eerste vragenlijst bleek dat $\mathrm{u}$ één of meer geneesmiddelen gebruikt heeft, waarover de onderzoeker nog iets meer wil weten. Daarom ontvangt u nu een tweede vragenlijst.

Als de vragen over meer dan een geneesmiddel gaan dan moet u voor elk geneesmiddel een aparte lijst invullen. Op patgina 1 van de vragenlijst staat de naam geschreven van het geneesmiddel waar de vragen over gaan.

We hopen dat u ook nu weer meedoet. wilt u de ingevulde vragenlijst terugsturen? Als u niet meer mee wilt doen, wilt u dan de groene omslag van de vragenlijst waar het nummer opstaat terugsturen in de enveloppe.

Hartelijk dank voor uw medewerking.

Hoogachtend,

Uw huisarts(en) 
Bijlage $\Pi b$

\section{tweede patiënten-enquête}

patiëntnummer........................

\section{geneesmiddelen onderzoek \\ in de}

huisartspraktijk

Rijksuniversiteit Limburg

Vakgroep huisartsgeneeskunde

Randwyck, Maastricht 
Geneesmiddelen Onderzoek

in de

Huisartspraktijk

Rijksuniversiteit Limburg Vakgroep Huisartsgeneeskunde

Te: Randwijck, Maastricht 
Kort geleden bent U zo vriendelijk geweest een enquêtelijst in te vullen voor een onderzoek naar voorschrift en gebruik van geneesmiddelen. We schreven in de inleiding dat $U$ mogelijkerwijs nog benaderd zou worden voor het invullen van een tweede lijst. We willen $U$ bij deze nog aanvullende vragen stellen.

Uit uw antwoorden is gebleken dat $U$ gebruikte. Wilt $U$ omtrent genoemd medikament de volgende vragenlijst beantwoorden. De vragen hebben betrekking op werschillende tijdvakken, namelijk het tijdvak van oktober 1992 tot oktober 1993, het tijdvak ervór en het tijdvak erna. Wanneer we overgaan naar een ander tijdvak zullen we dit duidelijk vermelden.

De vragenlijst bestaat uit drie soorten vragen. Van elke soort geven we hieronder een voorbeeld.

1. HET GEKOZEN ANTWOORD DIENT AANGEKRUIST TE WORDEN (PER VRAAG 1 ANTWOORD AANKRUISEN, TENZIJ DIT ANDERS WORDT VERMELD)

Voorbeeld"

Gebruikt U geneesmiddelen?

$1 \square$ nee

$2 \mathbb{\mathrm { j } a}$

2. HET ANTWOORD DIENT U OP DE STIPPELLIJN IN TE VULLEN:

Voorbeeld:

Hoeveel tabletten gebruikt $U$ per dag? 3

3. HET GEKOZEN ANTWOORD DIENT AANGEKRUIST TE WORDEN:

Voorbeeld:

zelden soms wak

kunt U uw gewoelens tonen $\quad 1 \square \quad 2 \square$

Zoudt $U$ de vragen willen beantwoorden in de volgorde zoals ze in de vragenlijst staan?

Dit is van belang omdat in de tekst aanwijzingen zijn opgenomen. Deze aarwijzingen geven aan welke vragen in uw geval kunnen worden overgeslagen. Indien U de vragen in de verkeerde vollgorde invult, mist $U$ deze aanwijzingen.

Mochten er onduidelijkheden zijn, dan kunt $U$ overdag inlichtingen krijgen bij: Mevr. M. Latour, onderzoeksassistente, tel. 043-882320 (dinsdag en donderdag) of Dhr. F. Vissers, huisarts/onderzoeker, tel. 043-611000 lpraktijknummery 


\section{ALGEMEEN}

1. Wat is uw geboortedatum?

dag.... maand.... jaar....

2. Wat is uw geslacht?
$1 \square \operatorname{man}$
$2 \square$ wrouw

We nemen u allereerst mee naar het tijdvak aktober 1992 tot oktober 1993

3. Hoe lang hebt $U$ in het tijdvak oktober 1992 tot oktober 1993 dit medikament dat vermeld staat op pagina 1 , gebruikt? Lees eerst onderstaande antwoordmogelijkheden $(3 \mathrm{a}, 3 \mathrm{~b}$ en $3 \mathrm{c})$ goed door alvorens $U$ uw keuze maakt.

3a. U gebruikte het medikament gedurende ÉEN periode? londer een PERIODE verstaan we een dlag, enkele dagen, een week. enkele weken, een maand of enkele maanden aaneengesloten)

$1 \square$ nee, ga door naar vraag 3b.

$2 \square$ ja, kruis aan wat van toepassing is:

1. $\square$ een periode van een dag

2. $\square$ een periode van enkele dagen

3. $\square$ een periode van een week

4. $\square$ een periode van enkele weken

5. $\square$ een periode van eern maand

6. $\square$ een periode van één tot drie maanden

7. $\square$ een nog langere periode

3b. U gabruikte het medikament MEERDERE perioden?

$1 \square$ nee, ga door naar vraag $3 c$.

2 [ ja, kruis aan wat van toepassing is:

1. $\square$ meerdere perioden van een dag

2. $\square$ meerdere perioden van enkele dagen

3. $\square$ meerdere perioden van een week

4. $\square$ meerdere perioden van enkele weken

5. $\square$ meerdere perioden van een maand

6. meerdere perioden van een tot drie mnd

7. $\square$ meerdere nag langere periaden

3c. U gebruikt het continu, d.w.z. blijvend en dagelijks?

$1 \square$ nee

$2 \square$ ja 
4. Als $U$ het medikament (vermeld op pagina 1) gebruikte in het tijdvak van oktober ' 92 tot oktober ' 93 , hoe gebruikte $U$ het dan?

Indien $U$ meerdere perioden gebruikt hebt, deze vraag

alleen beantwoorden voor de laatste periode

$1 \square$ dagelijks, ..... tabletten/capsules per dag

$2 \square$ niet dagelijks, maar minstens $1 \times$ per week, tabletten/capsules per week

3. niet iedere week, maar minstens $1 x$ per maand, ..... tabletten/capsules per maand

$4 \square$ anders, namelijk

5. Als $U$ dit medikament langer achter elkaar gebruikt hebt, hoe liet $U$ het recept voor dit medikament dan meestal herhalen?

$1 \square \cup$ ging naar het spreekuur en vroeg het uw huisarts persoonlijk

$2 \square \cup$ vroeg het aan uw huisarts via de telefoon

$3 \square \cup$ vroeg het via de assistente van uw huisarts

$4 \square \cup$ vroeg het aan een andere arts

$5 \square$ anders, namelijk

$6 \square$ niet van toepassing, nooit herhalingsrecept gevraagd

6. Wie heeft dit medikament de eerste keer aan $U$ voorgeschreven?

$1 \square$ eigen huisarts, tijdens spreekuur of visite

2. $\square$ eigen huisarts, via assistente

$3 \square$ specialist

$4 \square$ waarnemend huisarts

$5 \square$ iemand anders, namelijk

$29 \cdot 30$

7. Wilt $U$ hier beschrijuen voor welke klacht(en) $U$ dit medikament in het tijdvak van van oktober 1992 tot oktober 1993 gebruikte?

klacht:

8. Hebt $U$ voordat $U$ dit medikament ging gebruiken een andere behandeling voor deze klacht(en) gehad?

Meerdere antwoorden zijm mogelijk

(]) behandeling door de huisarts zonder medikament

$\square$ behandeling door specialist zonder medikament

$\square$ U kreeg een ander medikament, namelijk

$\square$ zelf een medikament gekocht, namelijk

DU werd verwezen naar

$\square$ anders, namelijk

$\square$ niet van toepassing 
Zoals $U$ waarschijnlijk wel weet, kunnen lichamelijke klachten ontstaan doordat men met problemen te kampen heeft, bijvoorbeeld slaapproblemen door drukte op het werk. Denkt U dat uw klachten (zie vraag 7) veroorzaakt worden door problemen, die U te verwerken hebt gehad van oktober 1992 tot oktober 1993 ? In onderstaand schema kunt $U$ de antwoorden aankruisen die op U van toepassing zijn.

\section{Denkt $U$ dat er een verband bestaat tussen de klachten (zie vraag 7) en problemen die $U$ hebt gehad:}

geen enig- nogal emstig
zins

9. op het werk of thuis met huishoudelijk werk

10. op school of met de studie

11. op financieel gebied

12. met huisvesting

13. met leefsituatie in uW buurt of straat

14. op sexueel gebied

15. met godsdienst of geloof

16. met maatschappij ontwikkelingen

17. met uw partner

18. met uw ouders

19. met uw kinderen

20. met uw schoonouders

21. met uw broers/zusters

22. met mensen in uw buurt

23. met vrienden/kennissen

24. in kontakten met anderen

25. met het verlies van een persoon

$\begin{array}{ll}1 \square & 2 \square \\ 1 & \square \\ 1 & 2 \square \\ 1 \square & 2 \square \\ 1 & 2 \square\end{array}$

3

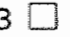

$4 \square$

3

3

$4 \square$

3

$4 \square$

$\begin{array}{ll}1 \square & 2 \square \\ 1 \square & 2 \square \\ 1 \square & 2 \square\end{array}$

3

$4 \square$

3

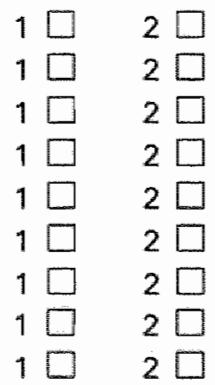
die U dierbaair is (partner, ouder, kind, vriend)
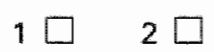

3

26. met verzorging van een chronisch zieke of invalide thuis

27. met eigen gezondheid

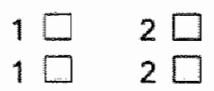

28. Indian $U$ problemen hebt gehad met uw gezondheid, kunt $U$ hieronder in het kort beschrijven am welke ziektes of klachten het ging? 
29. Bent $U$ tevreden (geweest) over de werking van dit medikament? Wilt $U$ op onderstaande lijn aankruisen hoe tevreden $U$ bent. Naarmate $U$ meer naar rechts aankruist, bent $U$ minder tevreden tot heel ontevreden.

heel heel tevreden ontevreden

30. Gebruikte U van dit medikament wel eens minder dan door de (huis)arts is voorgeschreven?
$1 \square$ nee, nooit ga door naar vraag 32
$2 \square$ ja, een enkele keer
$3 \square$ ja, regeimatig
$4 \square$ ja, vaak
$5 \square$ ja, heel vaak

31. Zo ja, hebt $U$ aan de (huis)arts toestemming gevraagd om minder van dit medikament te gebruiken?
$1 \square$ nee
$2 \square$ ja

32. Gebruikte $U$ van dit medikament wel eens meer dan door de (huis)arts is toegestaan?

$1 \square$ nee, nooit - -

$2 \square j a$, een enkele keer

$3 \square$ ja, regelmatig

$4 \square$ ja, vaak

$5 \square$ ja, heel vaak

33. Zo ja, hebt $U$ aan de (huis)arts toestemming gevraagd om meer van dit medikament te gebruiken?
$1 \square$ nee
$2 \square$ ja 
34. Is in de loop van de tijd de dosis thet aantal tabletten/capsules dat $U$ per dag slikt) van het door U gebruikte middel verhoogd?

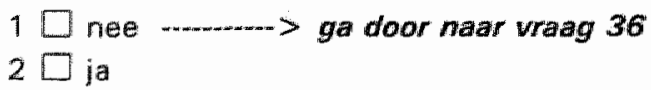

35. Zo ja, op wiens initiatief?

1. $\square$ van de Ihuistants

$2 \square$ van mijzelf

36. Kwam $U$ wel eens tabletten of capsules van dit medikament te kort?
$1 \square$ nee, nooit
$2 \square$ jal, een enkele keer
$3 \square$ ja, regelmatig
4. $\square$ ja, vaak
$5 \square$ ja, heel vaak

37. Vroeg $U$ wel eens extra tabletten of capsules van dit medikament aan anderen, bijvoorbeeld aan familie, kennissen, buren?
$1 \square$ nee, nooit
$2 \square$ ja, een enkele keer
$3 \square$ ja, regeimatig
$4 \square$ ja, vaak
5. $\square$ ja, heel vaak

38. Hebt $\mathrm{U}$ wel ens geprobeerd minder te nemen van dit medikament?
1 [I] nes, nooit
ga door naar vraag 47
$2 \square$ ja, en enkele keer
3 [ ja, regelmatig
$4 \square$ ja, vaak
$5[$ ja heel vaak

39. Zo ja, lukte dat?
$1 \square$ nee
2 [ ja 
40. Had $U$ dan last van ontwenningsverschijnselen of bent $U$ ooit ziek geworden na verminderen of staken van dit medikament?
$1 \square$ nee
$2 \square$ ja

41. Hebt U wel eens gemerkt, dat U steeds meer van dit medikament moest nemen om het gewenste effect te bereiken?
$1 \square$ nee
$2 \square$ ja

42. Hebt $U$ wel eens gemerkt dat $U$ van dit medikament afhankelijk was of er niet meer buiten kon?
$1 \square$ nee, nooit
$2 \square$ ja, een enkele keer
$3 \square$ ja, regellmatig
4. पja, vaak
$5 \square$ ja, heel vaak

43. Hebt $U$ wel eens lichamelijke klachten gehad door het nemen van dit medikament?
$1 \square$ nee, noait .........-> ga door naar vraag 45
$2 \square \mathrm{ja}$, een enkele keer
$3 \square$ ja, regelmatig
$4 \square$ ja, vaak
$5 \square$ ja heel vaak

44. Zo ja, welke klachten?

45. Heeft het nemen van dit middel wel eens tot problemen of conflicten geleid met familie, vrienden, werk, school of met de politie?

$1 \square$ nee, nooit --_-_- ga door naar vraag 47

$2 \square \mathrm{ja}$, een enkele keer

$3 \square$ ja, regelmatig

$4 \square$ ja, vaak

$5 \square$ ja, heel vaak 
46. Zo ja, kunt $U$ aangeven met wie $U$ daarover problemen had? meerdere antwoorden zijn mogelijk

$\square$ partner
$\square$ kinderen
$\square$ familie
$\square$ vrienden
$\square$ collega"s
$\square$ op school
$\square$ politie
$\square$ behandelend arts
$\square$ andere personen

47. Hebt $U$ ooit emotionele of psychische problemen gehad tijdens het gebruik van dit middel, bijwoorbeeld depressief zijn, niet geïnteresseerd zijn, het gevoel hebben gek te worden?

$1 \square$ nee, nooit -...... > ga door naar vraag 51

$2 \square$ ja, een enkele keer

$3 \square$ ja, regelmatig

$4 \square$ ja, vaak

$5[$ ja, heel vaak

48. Zo ja, kwam U ooit door dergelijke problemen in de knoop met uw manier van leven of met de dingen die Ul normaal doet?
$1 \square$ nee
$2 \square$ ja

49. Hebt $U$ het wel eens met de huisarts over dergelijke problemen gehad?

$1 \square$ nees

$2 \square$ ja

50. Hebt $U$ het wel eens met een andere hulpwerlener of instantie over dergelijke problemen gehad?
$1 \square$ nee
$2 \square$ ja 
51. Hebt $U$ in de loop van de tijd de huisarts wel eens om andere, sterkere middlelen gevraagd?

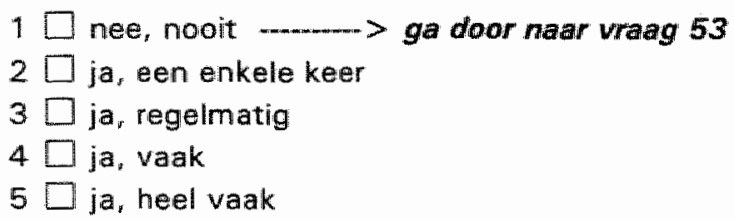

52. Zo ja, heeft de huisarts daarin toegestemd?
$1 \square$ nee
$2 \square$ ja

53. Hebt $U$ wel eens een slaap- of kalmeringsmiddel gebruikt om $U$ prettiger of meer ontspannen te voelen zonder dat dit $\mathrm{U}$ was voorgeschreven?
$1 \square$ nee, nooit
$2 \square$ ja, een enkele keer
$3 \square$ ja, regelmatig
$4 \square$ ja, vaak
$5 \square$ ja, heel vaak

54. Gebruikte $U$ wel eens alcohol bil dit medikament?

$1 \square$ nee, nooit

$2 \square$ ja, een enkele keer

$3 \square$ ja, regelmating

$4 \square \mathrm{ja}$, vaak

$5 \square$ ja, heel vaak

55. Gebruikt $U$ wel eens alcohol om $U$ ontspannen te voelen of goed te kunnen slapen?
$1 \square$ nee, nooit
$2 \square$ ja, een enkele keer
$3 \square$ ja, regelmatig
$4 \square$ ja, vaak
5. $\square$ ja, heel vaak

56. Wat zou $U$ doen als het door $U$ gebruikte middel werd gestopt of niet meer te verkrijgen zou zijn?

Antwoord: 
In voorgaande vragen ging het over het tijdvak van oktober 1992 tot oktober 1993. We nemen $U$ nu mee naar het tijdvak vón oktober 1992. Als $U$ het medikament tussen 1 oktober 1992 en 1 oktober 1993 voor het eerst gebruikt hebt, dan kunt $U$ vraag $57 \mathrm{t} / \mathrm{m} 80$ overslaam.

Als $U$ het medikament vermeld op pagina 1 ook vóor oktober 1992 gebruikt hebt dan dient $U$ de vragen $57 \mathrm{t} / \mathrm{m} 80$ wel in te vullen.

57. Wanneer hebt U dit medikament VOOR HET EERST gebruikt? maand .... jaar....

58. Wilt $U$ aangeven hoeveel tabletten/capsules per dag, week of maand $U$ toen (de EERSTE keen) gebruikte?

$1 \square$ dagelijks .... tabletten/capsules per dag

$2 \square$ niet dagelijks maar minstens $1 \times$ per week. .... tabletten/capsules per week

$3 \square$ niet wekelijks maar minstens $1 \times$ per maand .... tabletten/capsules per maand

$4 \square$ anders, namelijk

59. Wat was (waren), toen $U$ het medikament voor het eerst gebruikte, de KLACHT(en) waarvoor U het nodig had?
$1 \square$ onbekend
$2 \square$ dezelfde als de klachten in het tijdvak van oktober' 92 tot aktober " 93
$3 \square$ anders, nameliijk

60. Wat was de OORZAAK van de klacht(en) toen?

$1 \square$ onbekend $>$ ga door naar wraag 81

$2 \square$ zelfde oorzaak als van huidige klachten .... > ga door naar vraag 81

$3 \square$ anders dan huidige 
Indien U vóór oktober 1992 begonnen bent met dit medikament, vragen wij $U$ nu am in onderstaand schema aan te geven of er een verband is tussen uw klachten van TOEN, bij de "start van dit medikament", en eventuele problemen destijds.

\section{Denkt $U$ dat er een verband bestond tussen}

uw klachten van toen en problemen die $U$ toen had:

61. op het werk of thuis met huishoudelijk werk

62. op school of met de studie

63. op financieel gebied

64. met huisvesting

65. met leefsituatie in uw buurt of straat

66. op sexueel gebied

67. met godsailenst of geloof

68. met maatschappij ontwikgeen enigs- nogal ernstig
zins kelingen

69. met uw partner

$\begin{array}{llll}1 \square & 2 \square & 3 \square & 4 \square \\ 1 \square & 2 \square & 3 \square & 4 \square \\ 1 \square & 2 \square & 3 \square & 4 \square \\ 1 \square & 2 \square & 3 \square & 4 \square\end{array}$

70. met uw ouders

71. met uw kinderen

72. met uw schoonouders

$\begin{array}{llll}1 \square & 2 \square & 3 \square & 4 \square \\ 1 \square & 2 \square & 3 \square & 4 \square \\ 1 \square & 2 \square & 3 \square & 4 \square \\ 1 \square & 2 \square & 3 \square & 4 \square \\ 1 \square & 2 \square & 3 \square & 4 \square \\ 1 \square & 2 \square & 3 \square & 4 \square \\ 1 \square & 2 \square & 3 \square & 4 \square \\ 1 \square & 2 \square & 3 \square & 4 \square \\ 1 \square & 2 \square & 3 \square & 4 \square\end{array}$

73. met uw broers/zusters

74. met mensen in uw buurt

75. met vrienden/kennissen

76. in kontakten met anderen

77. met het verlies van een persoon die $\mathrm{U}$ dierbaar is (partner, ouder, kind, vriend)

78. met werzorging van een chronisch zileke of invalide thuis

79. met eigen gezondheid

$\begin{array}{llll}1 \square & 2 \square & 3 \square & 4 \square \\ 1 \square & 2 \square & 3 \square & 4 \square\end{array}$

80. Indien $U$ problemen had met uw gezondheid, kunt $U$ dan hieronder in het kort beschrijven om welke ziektes of klachten het ging? 
De volgende vragen gaan over het heden.

81. Gebruikt U het medikament nu nog steeds?

$1 \square$ nee

2 [ ja -.........> ga door naar vraag 85

82. Indien nee, wanneer bent $U$ dan gestopt met het gebruilk van thet medikament?

mnd ...... jaar ......

83. Waarom bent $U$ gestopt met het gebruik van het medikament?

84. Kunt $U$ aangeven wie hierbij een belangrijke ro gespeeld heeft?

Meerdere antwoorden zip̈n mogelijk

$\square$ niemand

$\square$ partmer

$\square$ kinderen

$\square$ familie

$\square$ vrienden

$\square$ collega's

$\square$ op school

[ politie

$\square$ behandelend arts

$\square$ andere personen

Als $U$ op vraag 81 "nee" geantwoord hebt, ga dan door naar pagina 14 . Als U op vraag 81 "ja" geantwoord hebt, ga dan door met vraag 85 . 
85. Undien $U$ het medikament nu nag steeds gebruikt, wilt $U$ hieronder aangeven hoe $U$ thet gebruikt:

$1 \square$ perioden van een dag

$2 \square$ perioden van enkele dagen

3. perioden van een week

$4 \square$ perioden van enkele weken

$5 \square$ perioden van een maand

$6 \square$ perioden van enkele maanden

$7 \square$ ellke dag

86. Hebt $U$ het het gevoel gehad dat $U$ het gebruik van deze tabletten/capsules zou moeten minderen/stoppen?
$1 \square$ nee
2 soms
$3 \square$ vaak
$4 \square$ heel vaak

87. Hebt $U$ dit oait besproken met iemand?
$1 \square$ nee
$2 \square$ ja
ga door naar vraag 89

88. Zo ja, wilt $U$ hier dan aangeven met wie?
$1 \square$ huisarts
$2 \square$ specialist
$3 \square$ iemand anders, namelijk

89. Denkt $U$ zonder hulp van deskundigen het gebruik van dit medikament te kunnen stoppen, als $U$ dat zou willen?
$1 \square$ nee
$2 \square$ ja

90. Wie zou $U$ het beste kunnen helpen om te stoppen met dit medikament?

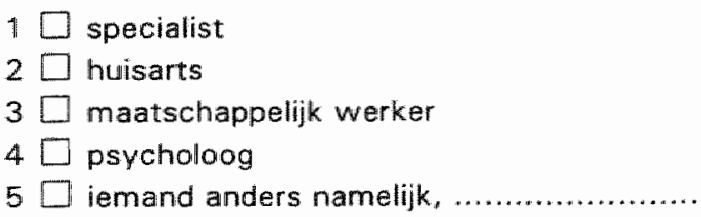


Misschien hebt $U$ het gevoel dat er bepaalde zaken die $U$ belangrijk acht met betrekking tot uw medikamentgebruik, niet ter sprake gekomen zijn. U kunt dan hieronder uw opmerkingen vermelden.

Het kan gebeuren dat, nadat de door $U$ ingevulde vragenlijst door ons gelezen is, er nog onduidelijkheden zijn. Vindt $U$ het goed dat in dat geval telefonisch kontakt met $u$ wordt opgenomen?

Ja, mijn tellefoonnummer is:

$\square$ nee

HARTELIJK DANK VOOR HET INVULLEN VAN DE VRAGENLIJST. 
Bijlage III

\section{artsen-enquête}

hoofdonderzoek 


\section{VRAGENLIJST VOOR ARTS BETREFFENDE PATIENT PF-GEBRUIKER}

praktijknr.

onderzoeksgroep $\mathrm{PF}$.....

volgnr.

patientregistratienr, oud

\section{artsiscode}

patientregistratienr nieuw

Uit de apotheekgegevens die u eerder controleerde, en/of de antwoorden van de postenquête van de patiēnt, blijkt deze in de periode van oktober 1992 to oktober 1993 het volgende slaap- en/of kalmeringsmiddel gebruikt te hebben:

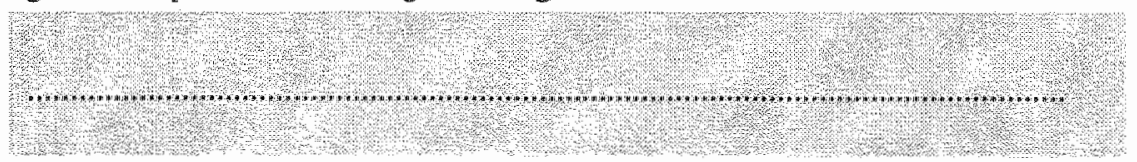

1 Was u op de hoogte wan dit gebruik?
10 ja
$==>$ ga door naar vraag 2
20 nee
$==>$ einde enquête

2 Werd(en) recept(en) voor dit middel via uw praktijk verstrekt?
$10 \quad$ ja
20 nee
30 onbekend
$=>$ ga door naar vraag 4
$=>$ ga door naar vraag 4

3 Indien ja, wat was de aard van het recept?

10 eerste voorschrift (in de periode "92-'93 voor het eerst voorgeschreven) $=\Rightarrow$ ga door naar waag 7

20 herhalingsrecept (reeds cerder, vóor de periode "92-93 voorgeschreven)

30 onbekend

$4 \quad$ Weet $u$ in welk jaar de behandeling met dit middel werd gestart?

Indien $u$ het niet meer exact weet kunt u ongeveer aangeven hoeveel jaren geleden gestart werd.
10 ja
10 gestart in $19 \ldots$.
20 ongeveer jaar geleden
20 nee, onbekend 
5. Wie startte de behandeling destijds?

10 ikzelf

20 een andere huisarts

30 een specialist

40 onbekend

6. Voor welke klacht(en) werd de patiënt destijds bij het starten wan het gebruik van dit middel behandeld? Indien u het nier weet omcirkel dan 'onbekend'

onbekend

7. Voor welke klacht(en) werd de patiënt in de periode '92-'93 met dit middel behandeld? Indien u het niet weet oncirkel dan 'onbekend' onbekend

8. Is na het eerste voorschrift door $u$ in de loop van de tijj de dosis van dit medicament veranderd?

10 ja

20 nee

$=\Rightarrow$ ga door naar vraag 11

30 onbekend

$=>$ ga door naar vraag 11

9. Zo ja, hoe veranderd?

10 verhoogd

20 verlaagd

10. Op wiens initiatief is de medicatiedosis veranderd? (Er zijn meerdere antwoorden mogelijk)

10 op initiatief van de patiènt

$20 \quad$ op mijn initiatief

30 op initiatief wan een andere huisarts

$4 O$ op initiatief van een specialist

50 onbekend

11. Kunt $u$ aangeven hoe volgens $u$ het behandelingseffect op de klachten van de patiènt was?

10 zeer goed

20 goed

30 matig

40 slecht

$50 \quad$ zeer slecht

60 onbekend

12. Zijn er ongewenste bijwerkingen opgetreden?

(Indien u 'ja' aankruist, vermeldt dan tevens de bijwerking)

10 ja, namelijk

20 nee

30 onbekend 
13. Heeft de patiënt $u$ wel eens on extra van het voorgeschreven medicament gevraagd, dat wil zeggen meer dan de gebruikelijke hoeveelheid die u aan patiënt voorschrijft?

10 nee, nooit

20 jas, een enkele keer

$30 \quad$ ja, regelmatig

$40 \quad$ ja, vaak

50 ja, heel valak

14. Indien patiènt daarom wroeg, stemde $\mathrm{u}$ daarin toe?

Wilt door middel van een kruisje op onderstaande schaal het antwoord aangeven.

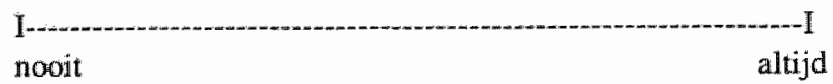

15a. Heeft de patiënt u wel eens om andere, sterkere medicamenten gevraagd?

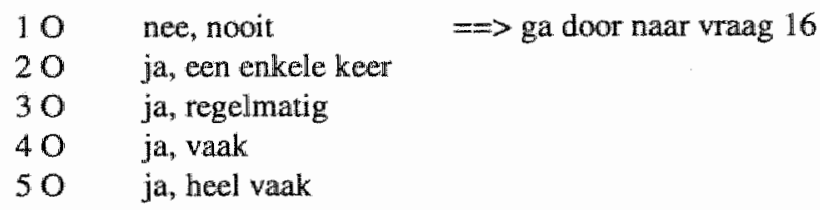

15b. Indien de patiënt om sterkere medicamenten vroeg, stemde u daarin toe?

Wilt door middel van een kruisje op onderstaande schaal het antwoord aangeven.

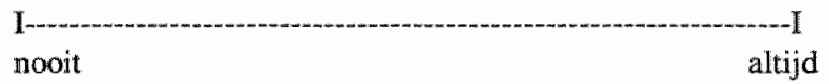

15c. Heeft de patiènt voordat hij dit middel is gaan gebruiken een of meerdere andere psychofarmaca (slap- of kalmeringsmiddelen) gebruikt?

10 ja, namelijk

20 nee

30 onbekend

16. Voelt u zich tegenover deze patiënt vrij om uw eigen wijze van voorschrijven te bepalen?

$\begin{array}{ll}10 & \text { nee, helemaal niet } \\ 20 & \text { meestal niet } \\ 30 & \text { soms wel, soms niet } \\ 40 & \text { meestal wel } \\ 50 & \text { ja, volledig }\end{array}$

17a. Wordt de patiènt nu nog steeds behandeld met dit middel?
$10 \quad$ ja
$\Longrightarrow$ ga door natar vraag $18 \mathrm{a}$.
20 nee
30 onbekend
$=>$ einde enquête 
17b. Waarom is de patiënt gestopt met het gebruik van dit middel?

10 op initiatief van de patie̊nt

20 op mijn advies

30 op advies van een andere arts

17c. Hoe is de patiënt gestopt met dit middel?

10 acuut gestopt

$2 \mathrm{O}$ op eigen houtje afgebouwd

30 afgebouwd volgens een door mij voorgeschreven schema

$4 \mathrm{O}$ onbekend

18a. Indien de patiënt nu nog behandeld wordt met dit middel, voor welke klacht wordt het middel momenteel gebruikt?

10 dezelfde klacht als bij de start van het gebruik

20 een andere klacht, namelijk

30 de klacht waavoor het middel nu gebruikt wordt is mij niet bekend

18b. Indien de patiënt nu met dit middel nog steeds behandeld wordt, hebt u wel eens geprobeerd de patiënt te motiveren ermee te stoppen?

10 ja

20 nee $\quad \Rightarrow$ einde enquête

18c. Indien de patiënt daarop inging, is het tot een stoppoging gekomen?

$\begin{array}{ll}10 & \text { ja } \\ 20 & \text { nee } \\ 30 & \text { onbelkend }\end{array}$



Bijlage IV

\section{artsen-enquête}

KLIP-onderzoek 


\section{Bijlage IV}

\section{ENQUETEFORMULIER}

\section{algemeen}

-assilstente

DNR PAT. PRAKTUK

naam MEDICAMENT. sterkte ....mg.

ACHTERGRONDVARIABELEN: leeftijd: .....jr geslacht: $\mathrm{M} / \mathrm{V}$

VERZEKERING: ZF / P

BURGERLIJKE STAAT: G/O/E/H/S/W/X/Q

WOONVERBAND:AI/AL/CO/EG/EL/GZ/GI/PA/THLXX/QQ

OPLEIDINGSNIVO: L/M/H/Q

\section{APOTHEKERSLIJST:}

woorschrift........datum recept... woorschrift..........datum recept. aantal E.... voorschrift........datum recept. aantal E....

woorschrift. .datum recept. aantal E.... aantal E....

\section{-arts}

WAS U OP DE HOOGTE VAN HET GEBRUIK? Ja / nee

START VAN GEBRUIK in onderzoeksperiode: ja / nee indien nee:

DUUR VAN GEBRUTK........maanden; indien > $12 \mathrm{mnd} \ldots . . .$. jaar / onbekend

KLACHT/DLAGNOSE VOOR GEBRUTK. onbekend

\section{OORZAAK VAN DE KIACHT}

psychosociaal probleem: / onbekend gezondheidsprobleem:

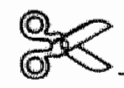




\section{Bijlage IV}

\section{ENQUETEFORMULIER}

IDNR PAT. PRAKTIJK ARTS

\section{specifiek}

vraag 1. acht $u$ het stoppen/reduceren AANGEWEZEN?

$\begin{array}{ll}\text { omcirkel ja nee, omdat: } & \text { 1. somatisch, psychiatrisch geïndiceerd } \\ \text { antwoord } & \text { 2. psychosociaal geindiceend } \\ \text { 3. gebrukt natar weinig }\end{array}$

vraag 2. acht $u$ dit HAALBAAR bij deze patiënt?

\begin{tabular}{|c|c|c|}
\hline $\begin{array}{l}\text { amcirkel } \\
\text { antwoord }\end{array}$ & nee, omdat: & 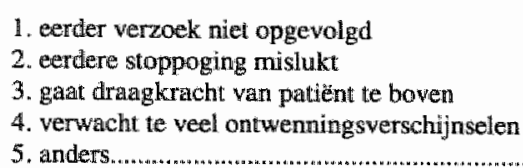 \\
\hline
\end{tabular}

vraag 3. de MOEITE om de patiënt te helpen bij het stoppen, heb ik er voor over.

$\begin{array}{ll}\begin{array}{l}\text { omcirkel ja } \\ \text { antwoord }\end{array} & \begin{array}{l}\text { 1. kost me te veel energie } \\ 2 \text {. onbelkend met methode }\end{array} \\ & 3 \text {. anders }\end{array}$

vraag 4. gaat u deze patiënt VRAGEN te stoppen/reduceren?

omcirkel ja nee, ondat:

artityoord

vraag 5. indien u 'ja' geantwoord hebt, wanneer gaat u dat DOEN?

omcirkel later, omdat:

antwoord:

Indien $u$ in VRAAG 1,2 of 3 een 'nee inwult betekent dat nadat $u$ die vraag hebt ingevuld, einde enquete. Alsi u bij opgave van reden "anders' scoort, wilt u dan in het kort omschrijwern wat u bedoelt, dil geldt ook voor wraag 4 waar gewraagd wordi naar reden van witstel of ütblijven van aktie. 